\title{
Platelet signaling to procoagulant activity and heterogeneity in thrombus formation : an in vivo and ex vivo approach
}

Citation for published version (APA):

Munnix, I. C. A. (2007). Platelet signaling to procoagulant activity and heterogeneity in thrombus formation : an in vivo and ex vivo approach. [Doctoral Thesis, Maastricht University]. Datawyse / Universitaire Pers Maastricht. https://doi.org/10.26481/dis.20070615im

Document status and date:

Published: 01/01/2007

DOI:

10.26481/dis.20070615im

Document Version:

Publisher's PDF, also known as Version of record

\section{Please check the document version of this publication:}

- A submitted manuscript is the version of the article upon submission and before peer-review. There can be important differences between the submitted version and the official published version of record. People interested in the research are advised to contact the author for the final version of the publication, or visit the DOI to the publisher's website.

- The final author version and the galley proof are versions of the publication after peer review.

- The final published version features the final layout of the paper including the volume, issue and page numbers.

Link to publication

\footnotetext{
General rights rights.

- You may freely distribute the URL identifying the publication in the public portal. please follow below link for the End User Agreement:

www.umlib.nl/taverne-license

Take down policy

If you believe that this document breaches copyright please contact us at:

repository@maastrichtuniversity.nl

providing details and we will investigate your claim.
}

Copyright and moral rights for the publications made accessible in the public portal are retained by the authors and/or other copyright owners and it is a condition of accessing publications that users recognise and abide by the legal requirements associated with these

- Users may download and print one copy of any publication from the public portal for the purpose of private study or research.

- You may not further distribute the material or use it for any profit-making activity or commercial gain

If the publication is distributed under the terms of Article $25 \mathrm{fa}$ of the Dutch Copyright Act, indicated by the "Taverne" license above, 


\section{Platelet signaling to}

\section{procoagulant activity and heterogeneity in thrombus formation}

an in vivo and ex vivo approach 
Platelet signaling to procoagulant activity and heterogeneity in thrombus formation

an in vivo and ex vivo appraoch

Thesis Universiteit Maastricht

ISBN 978-90-5278-630-8

(C) copyright I.C.A. Munnix, Maastricht 2007

Printed by Datawyse | Universitaire Pers Maastricht

Cover by Margriet Munnix, adapted from aboriginal art, Australia 


\title{
Platelet signaling to
}

\section{procoagulant activity and heterogeneity in thrombus formation \\ an in vivo and ex vivo approach}

\author{
PROEFSCHRIFT
}

ter verkrijging van de graad van doctor

aan de Universiteit Maastricht,

op gezag van de Rector Magnificus,

Prof. mr. G.P.M.F. Mols,

volgens het besluit van het College van Decanen,

in het openbaar te verdedigen op

15 juni 2007 om 14.00 uur

door

Imke Cornelia Adriana Munnix

Geboren op 16 maart 1979 te Roermond

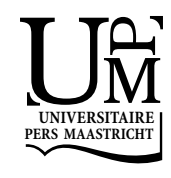




\section{Promotor}

Prof. Dr. J. Rosing

\section{Co-promotor}

Dr. J. W. M. Heemskerk

\section{Beoordelingscommissie}

Prof. Dr. J.F.C. Glatz (voorzitter)

Prof. Dr. H. Deckmyn (Katholieke Universiteit Leuven, België)

Prof. Dr. M.P. van Dieijen-Visser

Prof. Dr. J.G.R. de Mey

Prof. Dr. S.P. Watson (University of Birmingham, United Kingdom)

The study described in this thesis was supported by a grant of the Netherlands Heart Foundation (NHF-2002B014).

Financial support by the Netherlands Heart Foundation and the Dr. Ir. van de Laar Stichting for the publication of this thesis is gratefully acknowledged. 
The beginning is the most important part of the work Plato 



\section{Contents}

Chapter $1 \quad$ General introduction

Chapter $2 \quad$ Store-mediated calcium entry in the regulation of 31

phosphatidylserine exposure in blood cells from Scott

patients

Chapter $3 \quad$ Specific roles of PI3K isoforms $\alpha$ and $\beta$ in glycoprotein VI-

induced platelet signaling to procoagulant activity

Chapter $4 \quad$ Platelet receptor interplay regulates collagen-induced

thrombus formation in flowing human blood

Chapter 5

The glycoprotein VI-phospholipase $\mathrm{C} \gamma 2$ signaling pathway

controls thrombus formation induced by collagen and

tissue factor in vitro and in vivo

Chapter 6

Key role of platelet procoagulant activity in tissue-factor

and collagen-induced thrombus formation in arteries and veins in vivo

Chapter 7

Signaling-induced transient integrin activation controls

segregation of procoagulant and aggregatory

microdomains in thrombus formation

Chapter 8

General discussion

Summary

Samenvatting

Dankpuzzel

Curriculum vitae

Publications 



\section{Chapter 1}

General introduction 


\section{Platelets in haemostasis and thrombosis}

Blood platelets play a crucial role in haemostasis and thrombosis. Following vascular injury, the haemostatic response is considered to be driven by platelet activation, which leads to aggregation of the cells and plug formation. Impairment in platelet function can give rise to excessive blood loss. On the other hand, undesired platelet activation upon rupture of an atherosclerotic plaque can trigger a thrombotic response, which impedes blood flow through the diseased artery and can even completely occlude the vessel ${ }^{1}$. Depending on the location of the blood vessel, this atherothrombotic reaction may lead to stroke or myocardial infarction. These diseases are among the most common causes of death in the Western world.

It is clear that not only platelets are involved in haemostasis and thrombosis. Complementary to platelet activation acts the process of blood coagulation or clotting, resulting in the generation of thrombin and the formation of haemostatic fibrin clots. Since thrombin is also a main platelet activator, there is increasing interest in the interactions between platelet activation and coagulation ${ }^{2,3}$.

Thrombosis is normally classified as venous thrombosis (e.g., in deep veins) or arterial thrombosis (as in myocardial infarction and ischemic stroke). It is generally accepted that activated platelets and the coagulation system contribute in different ways to the thrombotic process in veins and arteries. Venous thrombosis is commonly associated with high coagulation activity, responsible for unwanted fibrin clot formation. On the other hand, arterial thrombosis is often linked to high platelet activation, which leads to formation of platelet-rich thrombi ${ }^{4,5}$. Nowadays, there are good examples of favourable combination therapy with anticoagulant and antiplatelet drugs. However, anticoagulants are still preferred in reducing venous thromboembolism, while antiplatelet agents are mostly used in the prevention of arterial thrombosis. This is in apparent paradox with the fact that thrombin is one of the most potent platelet agonists ${ }^{6}$. Furthermore, at least in vitro, antiplatelet drugs inhibit coagulation as well ${ }^{7}$.Together, this urges for better knowledge of the functions of platelets in relation to coagulation.

To provide a general background for the activation mechanisms of platelets and the coagulation system, in this chapter, an overview will be given of: key signaling processes implicated in platelet activation; the proposed roles of platelets in thrombin and thrombus formation; and finally, of the differences among individual platelets. 


\section{Platelet signaling to calcium mobilisation and beyond}

Most physiological platelet agonists evoke a sudden increase in the cytosolic free $\mathrm{Ca}^{2+}$ concentration. This holds for primary agonists such as collagen (exposed at a damaged vessel wall) and thrombin (the most reactive coagulation product); but also for the secondary agonists ADP and thromboxane $A_{2}\left(T x A_{2}\right)$, which are so-called autocoids that are produced by activated platelets themselves and enhance the platelet activation process. Elevated $\mathrm{Ca}^{2+}$ is implicated in almost all platelet responses, such as shape change, secretion, aggregation, development of procoagulant activity and clot retraction $^{8}$. As illustrated in Figure 1 , the key effector enzymes in the $\mathrm{Ca}^{2+}$ rise are members of the family of phosphoinositide-specific phospholipase C (PLC) isozymes, PLC- $\beta$ and PLC- $\gamma$.

Platelets become activated in response to collagen via the immunoreceptor family member, glycoprotein VI (GPVI). Collagen binding results in the phosphorylation of two tyrosines in the the Fc receptor $\gamma$-chain of the GPVI co-receptor ${ }^{9,10}$. The Fc receptor $\gamma$-chain contains an immunoreceptor tyrosine-based activation motif (ITAM), which includes two conserved tyrosine residues. Initial receptor phosphorylation is accomplished by the Src family kinases, Fyn and Lyn, which associate with proline-rich regions of $\mathrm{GPVI}^{11,12}$. Once phosphorylated, the Fc receptor $\gamma$-chain binds the tyrosine kinase Syk via its ITAM, which then becomes phosphorylated by Src kinases and also by itself $^{13}$. The activated Syk phosphorylates multiple signaling proteins, including the transmembrane adaptor LAT (linker for activation of T cells). Once phosphorylated, LAT serves as a docking site for proteins such as Gads, Grb2, phosphoinositide 3-kinase $(\mathrm{PI} 3 \mathrm{~K})$ and $\mathrm{PLC}-\gamma 2^{14}$. Activation of PLC $\gamma 2$ causes a prolonged increase in cytosolic $\mathrm{Ca}^{2+}$ concentration $^{15}$.

Human platelets express two receptors for thrombin, PAR1 and PAR4 ${ }^{16,17}$. Cleavage of these receptors by the protease thrombin exposes a short auto-activating peptide ligand, known as a tethered ligand ${ }^{18}$. Both activated receptors couple to the $G$ proteins, $\mathrm{Gq}$ and $\mathrm{G} 13$, of which the former is a strong activator of PLC- $\beta$ isoforms, mediating increases in cytosolic $\mathrm{Ca}^{2+}$ concentration ${ }^{19}$. The ability of thrombin to interact with PAR1 and PAR4 is facilitated by its ability to also bind to platelet GPIb-IX-V ${ }^{20,21}$.

Secondary mediators, of which $\mathrm{ADP}$ and $\mathrm{TxA}_{2}$ are the most important, are released by activated platelets, and act as paracrine agents that reinforce the platelet activation process. ADP is released by exocytosis of dense granules stored in the platelets. The key receptors for ADP are $P 2 Y_{1}$ and $P 2 Y_{12}{ }^{22}$. The first, $P 2 Y_{1}$, also couples to $\mathrm{Gq}^{19}$, which again stimulates PLC- $\beta$ and causes $\mathrm{Ca}^{2+}$ mobilisation ${ }^{22,23}$. 


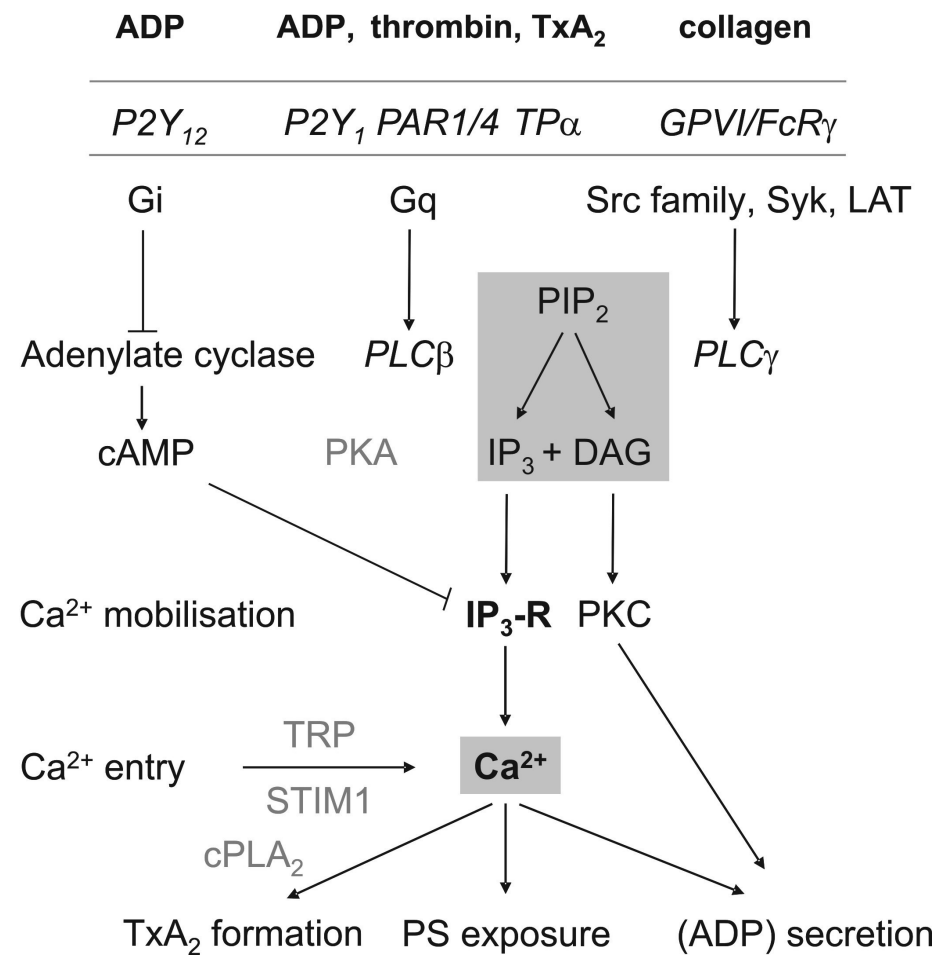

Figure 1 Overview of intracellular platelet signaling via phospholipase $C$ (PLC) isoforms and $\mathrm{Ca}^{2+}$ signaling. The ADP receptor $\mathrm{P} 2 \mathrm{Y}_{12}$ activates the $\mathrm{G}$-protein $\mathrm{Gi}$, which couples to and inhibits adenylate cyclase. This results in reduced cAMP level and inactivated protein kinase A (PKA), relieving the PKA-mediated suppression of $I_{3}$ receptors $\left(I_{3}-R\right)$. The ADP receptor $P 2 Y_{1}$, the thrombin receptors PAR1 and PAR4, and the TXA $A_{2}$ receptor TP $\alpha$ all activate $\mathrm{Gq}$, which couples to PLC $\beta$. Collagen activation of GPVI, via tyrosine phosphorylation of the Fc receptor $\gamma$-chain (FcR $\gamma$ ) triggers a cascade of phosphorylation reactions via Src and Syk kinases. The phosphorylated adaptor protein LAT mediates activation of PLC $\gamma 2$. Both PLC isoforms cleave $\mathrm{PIP}_{2}$ into $\mathrm{IP}_{3}$ and DAG. The former second messenger opens $\mathrm{IP}_{3}$ receptor channels which releases $\mathrm{Ca}^{2+}$ from intracellular stores, while the latter activates protein kinase $C$ (PKC), involved in secretion. $\mathrm{Ca}^{2+}$ release is followed by store-regulated $\mathrm{Ca}^{2+}$ influx, likely involving TPRC channels and the adaptor protein STIM1. Elevated $\mathrm{Ca}^{2+}$ can lead to phospholipase $\mathrm{A}_{2}\left(\mathrm{CPLA}_{2}\right)$ activation, arachidonate release and $\mathrm{TXA}_{2}$ formation; further to PS exposure at the platelet surface; and to secretion. Mechanisms of $\mathrm{Ca}^{2+}$ lowering are not indicated. For further explanations, see text.

On the other hand, $\mathrm{P}_{2} \mathrm{Y}_{12}$ couples to $\mathrm{Gi}$, which $\mathrm{G}$ protein inhibits adenylate cyclase and thus reduces the cyclic AMP level ${ }^{24}$.

Calcium-dependent activation of cytosolic phospholipase $A_{2}$ cleaves arachidonic acid from membrane phospholipids. The shortly living autocoid $\mathrm{TxA}_{2}$ is synthesised from arachidonic acid by the enzymes cyclooxygenase and $\mathrm{TxA}_{2}$ synthase $^{25}$. After diffusion across the plasma membrane, $\operatorname{TxA}_{2}$ binds to the $\operatorname{TP} \alpha$ receptors on the same or adjacent platelets. TP $\alpha$ also couples to $\mathrm{Gq}$ and thus activates PLC- $\beta^{26}$. 
Both PLC- $\gamma$ and PLC- $\beta$ isoforms cleave membrane-bound phosphatidyl inositol4,5-biphosphate to form the second messengers inositol-1,4,5-triphosphate $\left(\mathrm{IP}_{3}\right)$ and 1,2-diacylglycerol ${ }^{27}$. Once released from the membrane, the hydrophilic $\mathrm{IP}_{3}$ binds to $\mathrm{IP}_{3}$ operated $\mathrm{Ca}^{2+}$ channels in the endoplasmic reticulum membrane, surrounding intracellular $\mathrm{Ca}^{2+}$ stores. These mediate rapid release of $\mathrm{Ca}^{2+}$ into the cytosol, in a typically $\mathrm{Ca}^{2+}$-enhanced way ${ }^{28,29}$. Phosphorylation of the $\mathrm{IP}_{3}$ receptors by cyclic AMPdependent protein kinase down-regulates their $\mathrm{Ca}^{2+}$ channel activity, and thereby suppresses $\mathrm{Ca}^{2+}$ mobilisation ${ }^{30,31}$. The second PLC product, 1,2-diacylglycerol, remains membrane-associated and activates the serine-threonine protein kinase $\mathrm{C}$, which is implicated in secretion.

A direct effect of depletion of the $\mathrm{Ca}^{2+}$ stores is triggering of the process of store-regulated $\mathrm{Ca}^{2+}$ entry, by which $\mathrm{Ca}^{2+}$ from the extracellular medium enters into the cell. In platelets, this leads to substantial amplification of the $\mathrm{Ca}^{2+}$ signal ${ }^{8,32}$. The ion channels mediating $\mathrm{Ca}^{2+}$ entry and implicated in the linkage mechanism between store
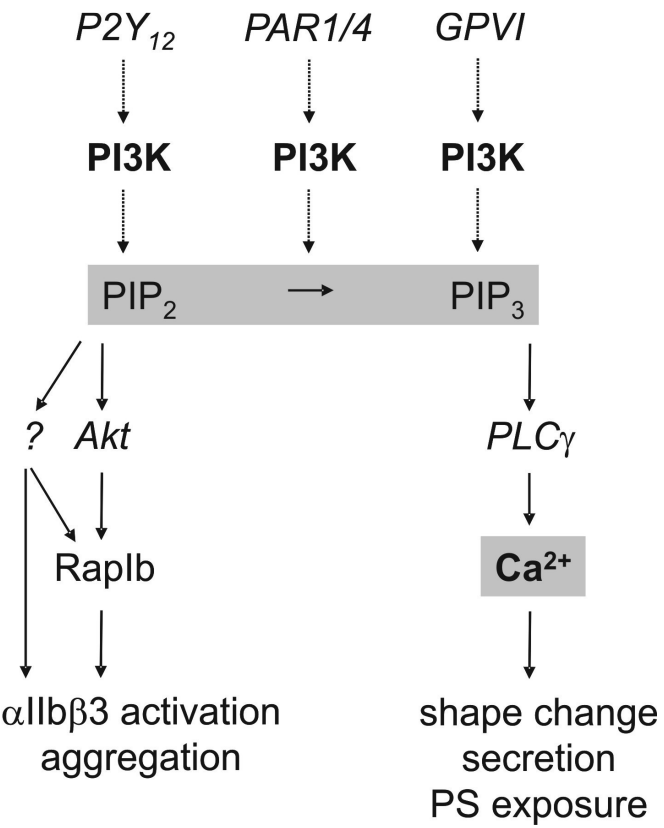

Figure 2 Overview of the roles of phosphoinositide 3-kinase (PI3K) in platelet activation. The $A D P$ receptor $P 2 Y_{12}$, the thrombin receptors PAR1 and PAR4, and the collagen receptor GPVI activate $\mathrm{PI} 3 \mathrm{~K}$, which converts $\mathrm{PIP}_{2}$ to the second messenger $\mathrm{PIP}_{3}$. PI3K activated downstream of GPVI stimulation plays a role in recruiting PLC $\gamma$ to the plasma membrane. As shown in Figure 1, elevated $\mathrm{Ca}^{2+}$ following PLC $\gamma 2$ activation, leads to PS exposure at the platelet surface and to secretion. Platelet secretion products reinforce the activation process through positive feedback mechanisms. Separately, $\mathrm{P}_{2} \mathrm{Y}_{12}$ and PAR1/4 stimulation activates the PI3K, Akt and Raplb pathway, which leads to integrin $\alpha$ llb $\beta 3$ activation and subsequent platelet aggregation. 
depletion and $\mathrm{Ca}^{2+}$ entry likely include the TRPC channels, as these can interact with platelet $\mathrm{IP}_{3}$ receptors ${ }^{28,33}$. Adaptor proteins in the endoplasmic reticulum membrane like STIM 1 are identified as putative reticular $\mathrm{Ca}^{2+}$ sensors that regulate the $\mathrm{Ca}^{2+}$ entry ${ }^{34}$. In particular, $\mathrm{Ca}^{2+}$ entry is required to achieve the prolonged, high cytosolic $\mathrm{Ca}^{2+}$ concentration for exposure of procoagulant phosphatidylserine (PS) at the platelet surface $^{35}$.

The PI3K enzyme plays a role in signaling from the major classes of surface receptors, including ADP, thrombin and collagen receptors. PI3K converts $\mathrm{PIP}_{2}$ to the phospholipid derivative phosphatidylinositol 3,4,5-trisphosphate $\left(\mathrm{PIP}_{3}\right)$ (Figure 2). The $\mathrm{Gi}$ and $\mathrm{Gq}$ protein-coupled pathways starting from $\mathrm{P}_{2} \mathrm{Y}_{12}$ and PAR1/4 lead to activation of $\mathrm{PI3K}$, which is involved in the activation of integrin $\alpha$ llb $\beta 3$ via the GTP-binding protein, Raplb $^{36}$. In addition, PI3K is also activated following GPVI stimulation, and plays a role in recruiting PLC $\gamma 2$ to the plasma membrane and, hence, in mediating $\mathrm{Ca}^{2+}$ mobilisation ${ }^{37}$.

$\mathrm{P}_{2} \mathrm{Y}_{12}$ plays a critical role in supporting platelet activation, because it serves as the major receptor for the secondary feedback agonist ADP, and also because it signals in a distinct way to other receptors. It is the ability of the $P 2 Y_{12}$ receptor to activate Rap1b towards $\alpha \operatorname{llb} \beta 3$ activation, that underlies its ability to act in synergy with other receptors. Although there are still missing links in this pathway, it is clear that a reduction in cyclic AMP is not required ${ }^{38-40}$. Important components in the signaling pathway to integrin activation are $\mathrm{PI} 3 \mathrm{~K}$ isoforms and the downstream mediator, Akt/PKB.

It has been reported that platelets contain various PI3K isoforms, i.e. the class IA isoforms $\mathrm{PI} 3 \mathrm{~K} \alpha, \beta$ and $\delta$, and the class IB isoform $\mathrm{PI} 3 \mathrm{~K} \gamma^{41}$. Both class IA and IB forms consist of a catalytic and regulatory subunit. In platelets, class IA PI3K forms comprise to date three $p 110$ catalytic subunits $(\alpha, \beta$ and $\delta)$ and three regulatory subunits $(85 \alpha, 85 \beta$, and $55 \gamma$ ). In addition, the p85 $\alpha$ protein possesses two alternatively spliced variants, p55 $\alpha$ and $\mathrm{p} 50 \alpha$. Of the various regulatory subunits, $\mathrm{p} 85 \alpha$ is the most abundantly expressed, and it interacts with the phosphorylated adaptor protein, LAT. The class IA regulatory subunits are characterized by the presence of $\mathrm{SH} 2$ and $\mathrm{SH} 3$ domains, by which the protein can interact with growth factor-like receptor complexes, such as the GPVI signaling complex.

The class IB PI3K $\gamma$ comprises a complex of a $\mathrm{p} 110 \gamma$ catalytic subunit and a unique p101 regulatory subunit. Thus, the p101 protein specifically binds to the $\mathrm{N}$ terminal domain of $\mathrm{p} 110 \gamma^{42}$. The regulatory subunit lacks $\mathrm{SH} 2$ and $\mathrm{SH} 3$ domains and is, in general, considered to interact with the $\beta / \gamma$ subunits of heterotrimeric $G$ proteins ${ }^{42}$. Whether this is also the case for platelets, has not yet been investigated. It is also not 
completely sure which regulatory subunit can bind to which catalytic subunit. As far as known, the inter-SH2 domains of $\mathrm{p} 85 \alpha, \mathrm{p} 55 \alpha, \mathrm{p} 50 \alpha, \mathrm{p} 85 \beta$ and $\mathrm{p} 55 \gamma$ constitutively interact with the $\mathrm{N}$-terminal domain of $\mathrm{p} 110 \alpha, \beta$ and $\delta$. Binding of the dual $\mathrm{SH} 2$ domains to tyrosine-phosphorylated adaptor proteins activates the kinase function of the p110 subunits. The precise signaling and functions of the various isoforms in platelets are unclear.

\section{Platelets and coagulation}

That platelets have an active role in the coagulation process appears from thrombin generation experiments in platelet-rich plasma. Here, thrombin generation strongly relies on the presence of activated platelets, as inhibition with several platelet antagonists has an anticoagulant effect by slowing down the formation of thrombin and fibrin $^{2,7,43}$. Indeed, binding of several coagulation factors to the platelet surface has been reported $^{38,44}$. The recognition that platelet activation and coagulation are mutually interacting processes has stimulated the research to find 'receptors' or binding components for coagulation factors on the platelet surface. Current evidence shows that these binding components comprise both surface phospholipids and glycoproteins (Table 1).

For long, it is known that resting platelets have an outer membrane phospholipid surface that is not active in coagulation ${ }^{45}$. Due to the activity of an aminophospholipid translocase, platelets and other cells sequester the aminophospholipids PS and phosphatidylethanolamine at the inner membrane leaflet $^{46,47}$. In most cell types, $A B C$ transporters or $\mathrm{P}_{4}$-ATPases are found to be responsible for the translocation reaction ${ }^{48}$. For platelets, $\mathrm{Ca}^{2+}$ ionophores and potent $\mathrm{Ca}^{2+}$-mobilizing agonists (collagen plus thrombin) are capable to evoke surface exposure of PS due to the so-called scramblase reaction ${ }^{35,45}$. However, the molecular identity of this scramblase has remained unclear ${ }^{48,49}$

Activated platelets that expose PS bind vitamin K-dependent coagulation factors (prothrombin and factors VII, IX and X) as well as vitamin K-dependent anticoagulation factors (protein $\mathrm{C}$ and $S$ ) via their Gla residues. Most of the blood coagulation enzymes belong to the serine protease family. They are primarily synthesized in the liver and require post-ribosomal modifications for proper functioning. The $\gamma$-carboxylation of $\mathrm{N}$-terminal glutamic acid residues to $\gamma$-carboxyglutamic acid (Gla) under the influence of a vitamin K-dependent carboxylase is considered of key importance for adequate function in coagulation. 
Table 1 Procoagulant entities at the platelet surface

\begin{tabular}{|c|c|c|c|}
\hline Surface component & Factor(s) bound & Function & Refs. \\
\hline $\begin{array}{l}\text { Aminophospholipids } \\
\text { (PS, PE) }\end{array}$ & $\begin{array}{l}\text { vitamin K-dependent } \\
\text { prothrombin, factors } \\
\text { VII(a), IX(a), X(a) }\end{array}$ & $\begin{array}{l}\text { assembly of tenase and } \\
\text { prothrombinase complex }\end{array}$ & 45 \\
\hline $\begin{array}{l}\text { Tissue factor or } \\
\text { another receptor }\end{array}$ & factor VII(a) & initiation of coagulation & 58,59 \\
\hline GPIb-V-IX & $\begin{array}{l}\text { thrombin } \\
\text { factor XI } \\
\text { factor XII }\end{array}$ & $\begin{array}{l}\text { facilitates thrombin activity } \\
\text { facilitates factor XI } \\
\text { activation } \\
\text { factor } X I \text { activation }\end{array}$ & $\begin{array}{l}79 \\
63 \\
64\end{array}$ \\
\hline Integrin $\alpha \operatorname{llb} \beta 3$ & $\begin{array}{l}\text { fibrin(ogen) } \\
\text { prothrombin }\end{array}$ & $\begin{array}{l}\text { platelet aggregation } \\
\text { facilitates prothrombin } \\
\text { activation }\end{array}$ & $\begin{array}{c}114,115 \\
65\end{array}$ \\
\hline Serotonin groups & $\begin{array}{l}\text { fibrinogen, factor } \mathrm{Va} \text {, } \\
\text { thrombospondin }\end{array}$ & $\begin{array}{l}\text { formation of coated } \\
\text { platelets }\end{array}$ & 111,116 \\
\hline Elusive EPR1 & factor $\mathrm{Xa}$ & $\begin{array}{l}\text { prothrombin activation } \\
\text { EPR1 is non-existent }\end{array}$ & $67-70$ \\
\hline Unknown receptor & $\begin{array}{l}\text { factor V(a) } \\
\text { factor XIIla }\end{array}$ & $\begin{array}{l}\text { facilitates prothrombin } \\
\text { activation } \\
\text { cross-linking of fibrin }\end{array}$ & $\begin{array}{l}38 \\
72\end{array}$ \\
\hline
\end{tabular}

The N-terminal Gla modules of the coagulation factors prothrombin, VII, IX, X, protein $\mathrm{C}$ and protein $\mathrm{S}$ contain between 9 and $11 \mathrm{Gla}$ residues that are pivotal for $\mathrm{Ca}^{2+}$ ion binding. The $\mathrm{Ca}^{2+}$-bound conformation of Gla modules is essential for binding of these coagulation proteins to negatively charged PS-containing (platelet) surfaces, and thus for initiation and propagation of blood coagulation. Accordingly, the PS-exposing membranes, by acting as assembly sites for the tenase and prothrombinase complexes, strongly accelerate the process of thrombin generation and, hence, clotting. In the tenase reaction, the protease factor $\mathrm{IXa}$, assisted by factor VIIla, together with its cofactor factor $\mathrm{Va}$, cleaves factor $X$ into its active form, factor $X a^{50}$. In the prothrombinase reaction, factor Xa catalyzes the cleavage of prothrombin into thrombin. Of relevance for this thesis, procoagulant (platelet) phospholipids (PS) stimulate these two reactions by several orders of magnitude ${ }^{51}$.

Abnormal regulation of platelet phospholipid asymmetry is incidentally seen in patients. In the rare Scott syndrome, impairment of phospholipid scrambling is accompanied by an increased bleeding tendency. Activated platelets from such patients are strongly impaired in their ability to support prothrombin and factor $X$ activation ${ }^{52}$. In addition, Scott platelets produce less microparticles ${ }^{53,54}$, which normally also propagate the coagulation process. Important for this thesis, it has been proposed that the storeregulated $\mathrm{Ca}^{2+}$ entry is defective in the Scott syndrome ${ }^{55}$. An alternative view is that 
platelets from Scott patients lack a $\mathrm{Ca}^{2+}$-dependent phospholipid scramblase activity, but no missing proteins have been found in these patients ${ }^{56}$.

It has been recognized that PS exposure is required, but not sufficient to explain the stimulation of coagulation by platelets $^{35,57}$. In recent years, evidence has been presented that (activated) platelets can also bind several coagulation factors via protein interactions (Table 1). Platelets interact with factor VIla, which is a serine protease initiating the coagulation process ${ }^{58}$. Some authors have reported that (activated) platelets contain tissue factor, which is the common cellular receptor for factor VIla ${ }^{59}$. However, others have challenged the significance of this finding, because platelets store large amounts of tissue factor pathway inhibitor ${ }^{60,61}$.

The GPIb-V-IX complex not only acts as a shear-dependent receptor for von Willebrand factor (VWF), but also provides binding sites for coagulation factors. For instance, GPIb-V-IX binds two thrombin molecules. Furthermore, this complex immobilises factor XI which, once activated by thrombin, converts factor IX to factor IXa which subsequently cleaves factor $X$ to factor $X a$, thus providing a pathway of thrombin generation independently of tissue factor ${ }^{62,63}$. Others have demonstrated that biotinylated factor XII binds to GPIb $\alpha$ in a $\mathrm{Zn}^{2+}$-dependent fashion ${ }^{64}$.

Clearly, integrin $\alpha$ llb $\beta 3$ is the major fibrin(ogen)-binding protein on activated platelets. However, this integrin also binds prothrombin even on non-stimulated platelets, thus providing a local pool for thrombin generation under coagulant conditions ${ }^{65}$. Coagulation factor binding can also be achieved by serotonin residues on the platelet surface. Dale and co-workers show that stimulation of platelets with collagen and thrombin, but also with $\mathrm{Ca}^{2+}$ ionophores, results in so-called COAT (collagen- and thrombin) stimulated platelets, currently also indicated as coated platelets ${ }^{66}$. These platelets can expose serotonin-conjugated proteins that interact with serotonin binding sites on fibrinogen and thrombospondin. The same platelets may also bind fibronectin and VWF, as well as granule-derived factor $\mathrm{Va}$, which is involved in coagulation. It is suggested that the coated platelets also express surface PS and support prothrombinase activity $^{66}$.

Some authors have suggested that platelets bind factor $\mathrm{Xa}$ via a receptor consisting of anionic phospholipids, factor $\mathrm{Va}$ and effector cell protease receptor-1 $(E P R 1)^{67}$. Preliminary support for involvement of EPR1 came from studies that compared the binding characteristics of factor Xa onto phospholipid vesicles and thrombin-activated platelets $^{68,69}$. Others, however, were unable to demonstrate involvement of an EPR1-like protein in the assembly of the prothrombinase complex at the surface of activated platelets $^{70}$. The EPR1 work came into a new perspective with the finding that the so- 
called 'EPR1' gene actually encodes for a protein regulating apoptosis, and that the elusive factor $\mathrm{Xa}$ receptor protein is not transcribed in cells ${ }^{71}$. The transglutaminase factor XIIla may also bind to platelets, and functions to mediate the cross-linking of coagulation factors with $\alpha$ llb $\beta 3$ and associated proteins ${ }^{72}$.

Of all platelet receptors, especially GPVI has been linked to PS exposure and procoagulant activity ${ }^{73,74}$. However, at the start of the investigations of this thesis, only very little was known of the signaling pathways used by GPVI to evoke this response, nor of the consequences of platelet GPVI stimulation for coagulation factor binding Thrombin also stimulates procoagulant activity, although its effect is less profound than that of GPVI, but synergizes with the collagen-induced procoagulant response ${ }^{75}$. In the literature it has extensively been discussed which thrombin receptor is responsible for the procoagulant activity. The receptors, PAR $1^{76,77}, \mathrm{PAR} 4^{76}$, and $\mathrm{GPIb}-\mathrm{IX}-\mathrm{V}^{78-80}$, have all been proposed as potential mediators of this thrombin response. Recent results, using selective inhibitors of the various receptors, show that the synergistic effect of thrombin in collagen-induced platelet procoagulant activity is mediated not through GPIb-IX-V or PAR4, but through PAR1 ${ }^{20}$.

\section{Platelets and coagulation in thrombus formation}

So far, the initial events leading to collagen-induced platelet aggregation and thrombus formation under shear have mainly been studied by in vitro flow studies using anticoagulated human and murine blood (Figure 3). Under conditions of high, arterial shear rates, platelets initially adhere to immobilized VWF via GPIb-V-IX, and subsequently via integrin $\alpha \operatorname{llb} \beta 3^{81,82}$. These interactions cause limited platelet activation $^{83}$. Since VWF binds with a high affinity to collagen, the VWF interaction predisposes platelets to collagen-induced activation and facilitates thrombus formation ${ }^{84,85}$. The subsequent order of events differs from platelet to platelet both in man and mouse ${ }^{86}$. Some platelets on collagen become rapidly activated by the collagen receptor, GPVI, which signals to PLC- $\gamma 2$ and $\mathrm{Ca}^{2+}$ mobilization, as described above. Signaling via GPVI leads to activation of a second collagen receptor, integrin $\alpha 2 \beta 1$. This event is required for stable adhesion and full activation ${ }^{87}$. However, other platelets, perhaps interacting with different motifs in collagen, follow a different order of events by first stably adhering to the collagen via integrin $\alpha 2 \beta 1$ before showing GPVI-induced activation responses. Collagen-adhered platelets release autocoids like ADP and TxA which stimulate passing platelets to activate their $\alpha$ llb $\beta 3$ integrins ${ }^{88-90}$. Instantaneously, these platelets then aggregate via multiple $\alpha$ llb $\beta 3$-fibrinogen interactions, which are 
enforced by GPIb-V-IX binding to plasma-derived $\mathrm{VWF}^{81}$. Such thrombi are intrinsically unstable structures that require strong adhesion to collagen and continuous platelet activation. This appears from the findings that they disintegrate in the absence of $\alpha 2 \beta 1^{91}$ or when $\mathrm{P} 2 \mathrm{Y}_{12}$ signaling is blocked ${ }^{92,93}$.

Platelet adhesion to collagen also triggers the so-called procoagulant response ${ }^{73,94}$. In response to prolonged elevation in cytosolic $\mathrm{Ca}^{2+}$, platelets can start to expose PS and form blebs, which later shed as microparticles (Figure 4). Both the blebbing platelets and the shedding of microparticles contribute to the stimulation of coagulation. Thus, in the presence of plasma, this response greatly stimulates thrombin generation $^{95}$. Although the importance of this platelet response is known upon flow over fibrinogen ${ }^{96}$, still pertinent questions are how platelet interaction with collagen and vWF can trigger procoagulant activity under venous and arterial flow conditions, and how the various receptors communicate in establishing this platelet response.

In vitro experiments have significantly contributed to our understanding of the mechanisms of platelet activation and thrombus formation. However, in vivo thrombosis

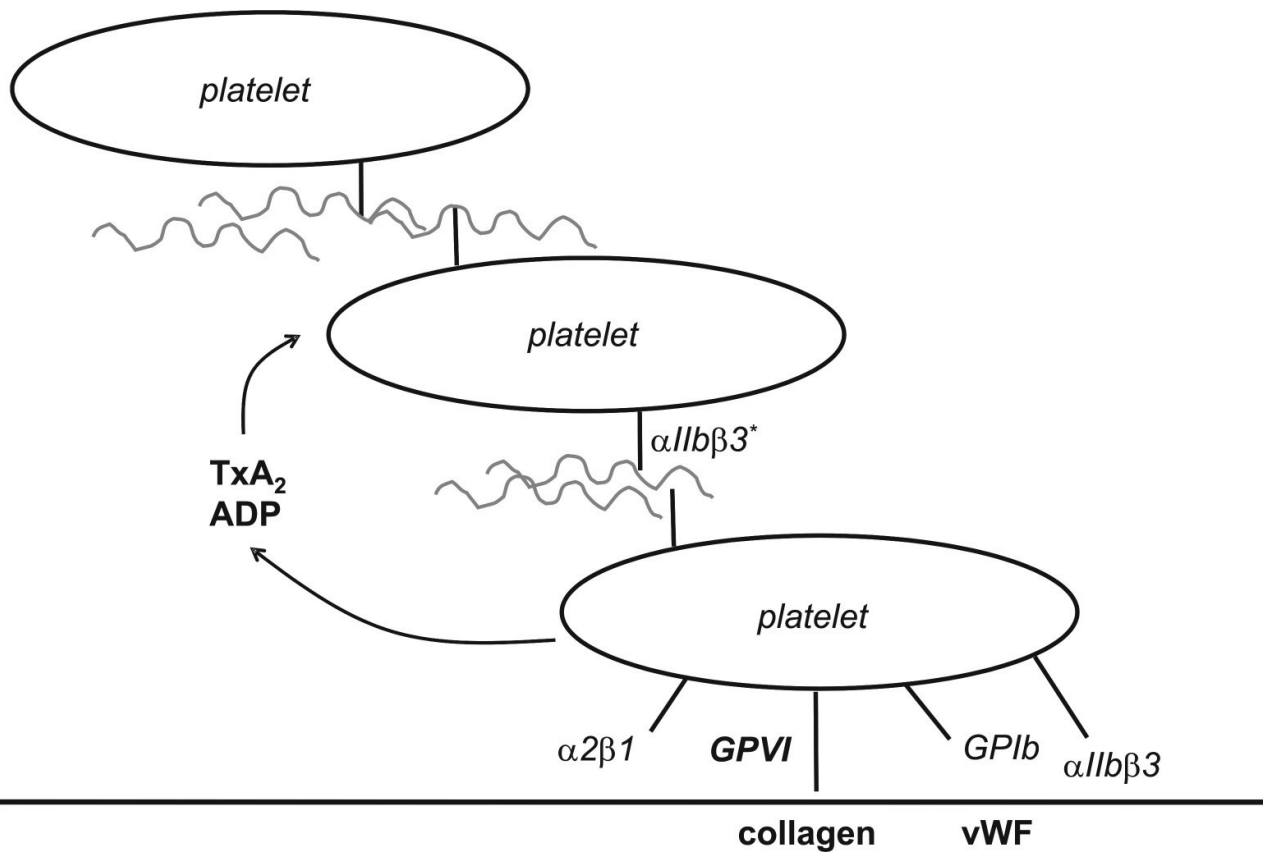

Figure 3 Platelet adhesion and aggregation on collagen under high shear. Platelets bind to collagen fibres containing VWF via multiple receptors and become activated via GPVI. Various signaling pathways mediate activation of integrins and release of paracrine agonists, such as $\mathrm{TxA}_{2}$ and ADP. Platelet aggregates are formed under shear via interactions of activated $\alpha$ llb $\beta 3$ and GPIb-V-IX with fibrinogen and vWF, respectively. 
studies are needed for ultimate verification of the (patho)logical importance of these mechanisms ${ }^{97}$. In the last few years, several animal models have been developed to investigate the role of platelets in the thrombotic process in vivo. Here, only murine models that are relevant for the present thesis are introduced. The possibilities and limitations of these models have been discussed more extensively elsewhere ${ }^{98}$.

In a well established microvascular model, thrombus formation is induced by topical application of the free radical generating agent, ferric chloride, on mouse mesenteric vessels ${ }^{99}$. Ferric chloride treatment leads to substantial damage of the vessel wall, i.e. denudation of the endothelial cells and exposure of the collagen-containing extracellular matrix to the blood stream. The ensuing thrombotic process is usually followed by intravital microscopic imaging techniques ${ }^{100}$. An other way of injury of these microvessels is by application of high-energy laser light that is focused through microscope optics, which are also used to detect thrombus formation ${ }^{101}$. An advantage of the latter technique is that more precise, local damage can be applied, but a disadvantage is the likelihood of damaging vascular structures by the high energy power of the laser beam. In addition, several macrovascular arterial thrombosis models have been developed. In one of these, vascular injury is induced by ligation of the mouse carotid artery, which also causes loss of the endothelial cell layer ${ }^{102}$.

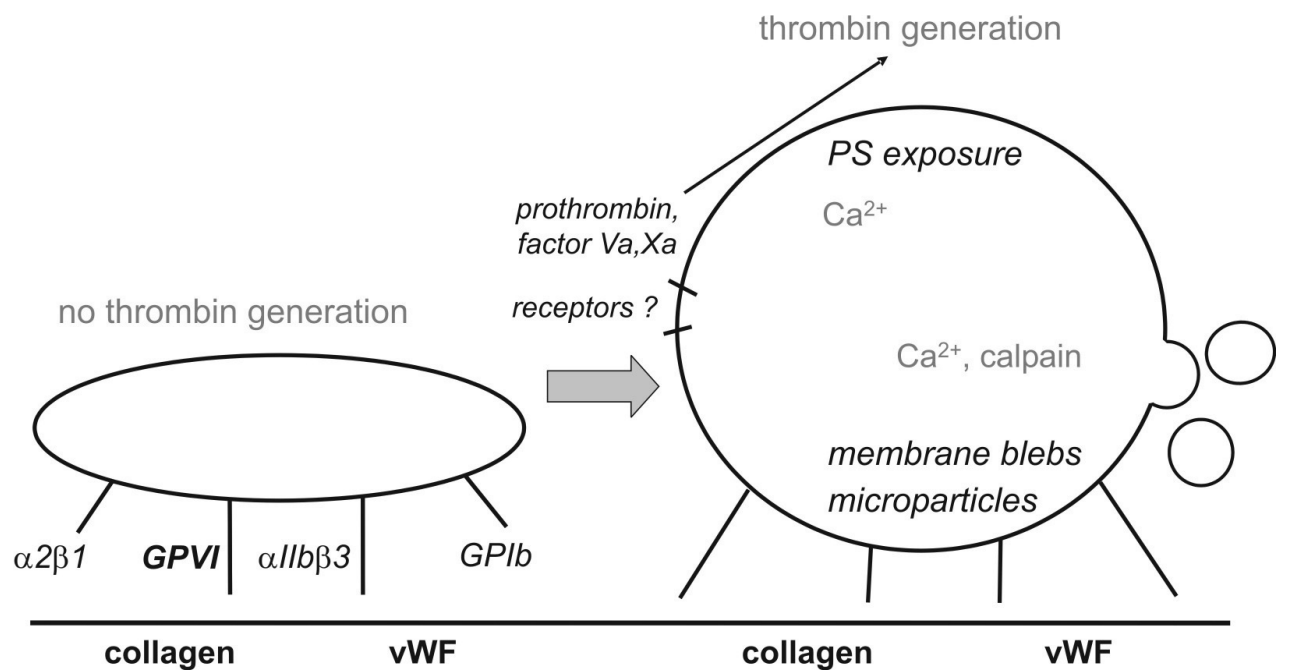

Figure 4 Function of collagen receptors in platelet procoagulant activity. Platelets binding to collagen and activated by GPVI can, depending on their activation state, transform into round structures with membrane blebs and shedding microparticles. These platelets expose PS and are active in thrombin generation and coagulation. Modified after Heemskerk et al. ${ }^{94}$. 
In both these micro- and macrovascular models, collagen-induced platelet activation has been proposed to play a key role in triggering the thrombotic process ${ }^{102-}$ 105. Alternatively, in both ferric chloride and laser-induced thrombus formation, an important role for tissue factor and thrombin and, hence, for coagulation has been identified $^{99,105}$. In this respect, some authors have even questioned the importance of platelet-collagen interaction ${ }^{106}$. These apparent discrepancies in the literature may be resolved by the possibility that collagen (platelet activation) and thrombin (coagulation) have additive or synergistic roles in arterial thrombosis, and that the relative importance of either of them can vary depending on the local conditions, e.g. the precise way of vascular damage, the local flow and the responsiveness of platelets. Accordingly, in spite of all the in vitro and in vivo work, it is still unclear whether and how the processes of platelet activation and coagulation integrate in thrombus formation in arteries and veins.
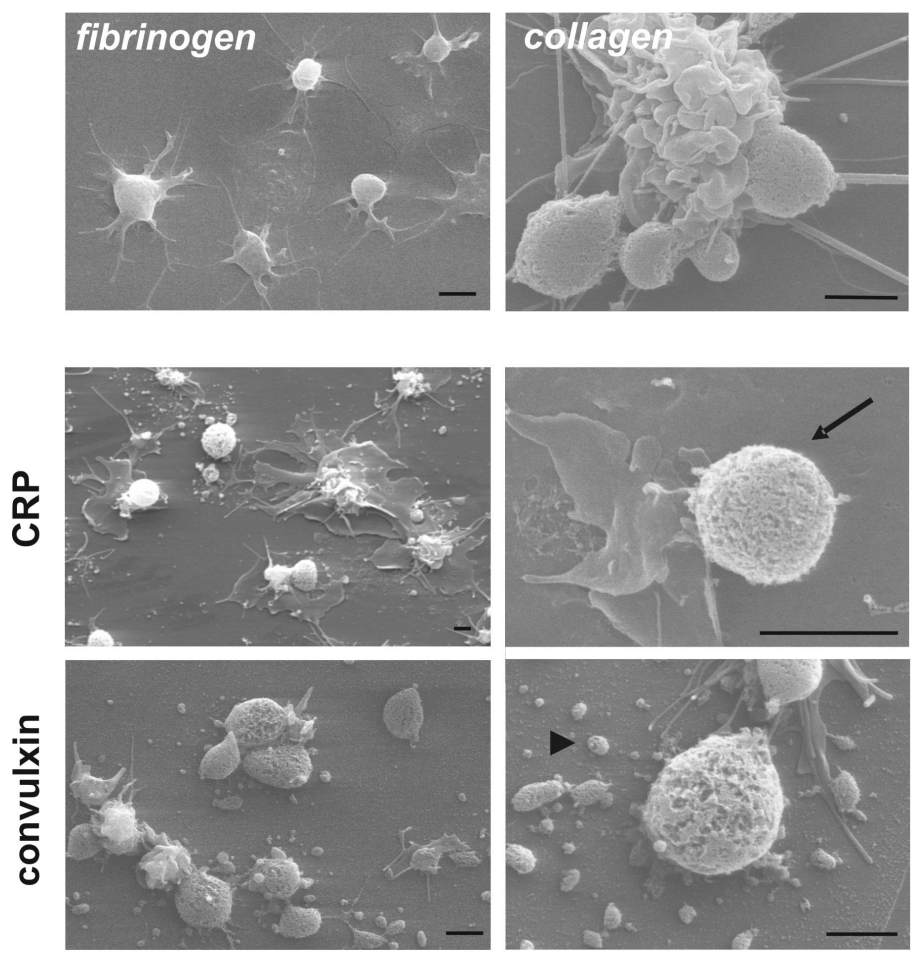

Figure 5 Morphology of procoagulant platelets adhering to collagen under static conditions. Scanning electron microscopic images of human platelets adhered to fibrinogen, collagen, or specific GPVI-binding surfaces. Note sponge-like structures (arrow) and microparticles (arrow head) representing procoagulant structures. Bars represent $2 \mu \mathrm{m}$. Modified after Siljander et al. ${ }^{74}$. 


\section{Heterogeneity in platelet responses}

Platelets that come into contact with a collagen surface or that are stimulated with GPVI-activating agents can show three different morphologic responses: pseudopod formation followed by spreading, clustering into aggregates, and formation of blebs which shed as microparticles ${ }^{74}$. Some spread platelets may also show membrane contraction and subsequent fragmentation ${ }^{72}$. This heterogeneity in responses even occurs when platelets are adjacent on a collagen surface (Figure 5). A similar heterogeneity is found under flow conditions, when whole blood is perfused over collagen, in which case some platelets integrate into multi-cellular aggregates while other platelets develop into blebbing cells ${ }^{85,90}$. There are some, but incomplete, indications in the literature that may explain these typical differences between platelet responses.

Explanations can be found in inherent, biochemical differences between platelets from an individual as well as in differences in environmental factors. Evidence that not all platelets are structurally similar comes from many flow cytometric studies, where the staining of platelets with antibodies or probes against surface glycoproteins or receptors in many instances shows considerable differences in binding extent among platelets of one subject, regardless of the antigen or probe used. Thus, even independent of their size, some platelets will express more surface receptors than others $^{107}$. Such structural heterogeneity has already been seen at the level of differentiating megakaryocytes. For instance, individual human megakaryocytes express different levels of $\alpha$ llb $\beta 3$ and GPIb-V-IX, while they simultaneously differ in $\mathrm{Ca}^{2+}$ signaling properties ${ }^{108}$. Furthermore, some differentiating megakaryocytes appear to keep their immature signaling properties (e.g. prostacyclin-induced $\mathrm{Ca}^{2+}$ mobilisation), and can transmit these to a subpopulation of circulating platelets ${ }^{109}$. Thus, platelets in the blood are derived from megakaryocytes with a markedly different expression of adhesive receptor and signaling molecules. It is therefore not a surprise that single platelets from one subject, when placed on a coverslip, also show large differences in $\mathrm{Ca}^{2+}$ signal patterns ${ }^{29}$. Such differences in responsiveness may explain why, upon stimulation with collagen and thrombin, only a subpopulation of platelets expresses $\mathrm{PS}^{110}$, sheds microparticles ${ }^{72}$, transforms into coated platelets with serotonin binding sites ${ }^{111}$, or preferentially binds coagulation factors ${ }^{112}$.

Especially under shear conditions, individual platelets are likely to encounter different activating environments. For instance, during flow over collagen, the first platelets that bind to collagen (designated as vanguard cells) were found to communicate their activation status to subsequent follower platelets, and thus recruiting 
the latter into developing aggregates ${ }^{113}$. Vanguard platelets may differ from other platelets by releasing ADP, which implicates that some collagen-bound platelets are more capable in attracting other (follower) platelets than others.

Taken together, it is well conceivable that, during the thrombotic process, biochemical and structural differences between platelets as well as micro-environmental diversity sensed by these platelets determines the different types of platelet responses. However, the present literature has only begun to determine the extent and relevance of this heterogeneity for the thrombus-forming process.

\section{Research outline of this thesis}

In this thesis the interaction mechanisms between platelet activation and coagulation are studied on different levels of complexity: using isolated platelets; by way of an in vitro model of thrombus formation under flow in the presence and absence of coagulation; and by in vivo models of thrombus formation in small and large vessels. Since store-mediated $\mathrm{Ca}^{2+}$ entry is essential for the procoagulant response of platelets, we have investigated in chapter 2 whether the $\mathrm{Ca}^{2+}$ entry process is impaired in the Scott syndrome. Measurements are performed of $\mathrm{Ca}^{2+}$ fluxes and PS exposure in isolated platelets and in B-cell lymphoblasts from two Scott patients. In chapter 3, we describe a study on the role of various PI3K isoforms in the regulation of $\mathrm{Ca}^{2+}$ signaling and procoagulant activity using platelets that are stimulated via their collagen or thrombin receptors. In the in vitro flow studies reported in chapter 4 , the interacting roles of the adhesive receptors for WWF (GPIb-V-IX and $\alpha$ llb $\beta 3$ ) and collagen (GPVI and $\alpha 2 \beta 1$ ) are examined upon thrombin formation and procoagulant activity during high-shear perfusion of whole blood. Novel antibodies and peptides directed against the two collagen receptors are used to specifically unravel the function of each receptor molecule. Chapter 5 introduces the processes of thrombin generation and coagulation in flowadhesion experiments. The investigations aim to determine how signaling modules of the GPVI pathway of platelet activation control thrombus formation under coagulant conditions both in vitro and in vivo. Particular attention is paid to the generation and importance of PS-exposing platelets. To study the interaction mechanisms between platelet activation and thrombin generation in vivo, chapter 6 describes the development and use of a mouse model of arterial and venous thrombosis. Intervention experiments have allowed to study the synergy and interplay of these two processes. In chapter $\mathbf{7}$, this work is extended by demonstrating that temporal changes in intracellular signaling properties determine the 'fate' of a platelet to become either procoagulant or 
proaggregatory in vitro and in vivo. Finally, in chapter 8 I have discussed the novel findings of this thesis in relation to the current literature.

\section{References}

1. Ruggeri ZM. Platelets in atherothrombosis. Nat Med. 2002;8:1227-1234.

2. Béguin $\mathrm{S}$, Kumar R. Thrombin, fibrin and platelets, a resonance loop in which von Willebrand factor is a necessary link. Thromb Haemost. 1997;78:590-594.

3. Phillips DR, Conley PB, Sinha U, Andre P. Therapeutic approaches in arterial thrombosis. J Thromb Haemost. 2005;3:1577-1589.

4. Goto S. Understanding the mechanism and prevention of arterial occlusive thrombus formation by anti-platelet agents. Curr Med Chem Cardiovasc Hematol Agents. 2004;2:149-156.

5. Steinhubl SR, Moliterno DJ. The role of the platelet in the pathogenesis of atherothrombosis. Am J Cardiovasc Drugs. 2005;5:399-408.

6. Van der Meijden PEJ, Heemskerk JWM, Hamulyak $\mathrm{K}$, ten Cate $\mathrm{H}$. Platelets in venous thrombosis. J Thromb Haemost. 2005;3:2575-2577.

7. Reverter JC, Béguin S, Kessels H, Kumar R, Hemker HC, Coller BS. Inhibition of plateletmediated, tissue-factor-induced thrombin generation by the mouse/human chimeric 7E3 antibody. Potential implications for the effect of c7E3 Fab treatment on acute thrombosis and 'clinical restenosis'. J Clin Invest. 1996;98:863-874.

8. Heemskerk JWM. Calcium and platelets. In: The Molecular Basis of Calcium Action in Biology and Medicine (Pochet, R, Donato, R, Haiech, J, Heinzmann, C and Gerke, V, eds), Kluwer Acad Publ, The Hague (the Netherlands). 2000:45-71.

9. Gibbins J, Asselin J, Farndale R, Barnes M, Law CL, Watson SP. Tyrosine phosphorylation of the Fc receptor $\gamma$-chain in collagen-stimulated platelets. J Biol Chem. 1996;271:18095-18099.

10. Briddon SJ, Watson SP. Evidence for the involvement of p59fyn and p53/56lyn in collagen receptor signaling in human platelets. Biochem J. 1999;338

11. Quek LS, Pasquet JM, Hers I, Cornall R, Knight G, Barnes M, Hibbs ML, Dunn AR, Lowell CA, Watson SP. Fyn and Lyn phosphorylate the Fc receptor $\gamma$-chain downstream of glycoprotein $\mathrm{VI}$ in murine platelets, and Lyn regulates a novel feedback pathway. Blood. 2000;96:4246-4253.

12. Suzuki-Inoue K, Tulasne D, Shen Y, Bori-Sanz T, Inoue O, Jung SM, Moroi M, Andrews RK, Berndt MC, Watson SP. Association of Fyn and Lyn with the proline-rich domain of glycoprotein VI regulates intracellular signaling. J Biol Chem. 2002;277:21561-21566.

13. Asselin J, Gibbins JM, Achison M, Lee YH, Motron LF, Farndale RW, Barnes MJ, Watson SP. A collagen-like peptide stimulates tyrosine phosphorylation of Syk and phospholipase $\mathrm{C} \gamma 2$ in platelets independent of the integrin $\alpha 2 \beta 1$. Blood. 1997;89:1235-1242.

14. Gibbins JM, Briddon S, Shutes A, van Vugt MJ, van de Winkel JGJ, Saito T, Watson SP. The p85 subunit of phosphatidylinositol 3-kinase associates with the Fc receptor $\gamma$-chain and linker for activation of T cells (LAT) in platelets stimulated by collagen and convulxin. J Biol Chem. 1998;273:3447-3443.

15. Poole AW, Watson SP. Regulation of cytosolic calcium by collagen in single platelets. $\mathrm{Br} \mathrm{J}$ Pharmacol. 1995;115:101-106.

16. Coughlin SR. Thrombin signaling and protease-activated receptors. Nature. 2000;407:258-264

17. Brass LF, Molino M. Protease-activated G protein-coupled receptors on human platelets and endothelial cells. Thromb Haemost. 1997;78:234-241.

18. Vu TK, Hung DT, Wheaton VI, Coughlin SR. Molecular cloning of a functional thrombin receptor reveals a novel proteolytic mechanism of receptor activation. Cell. 1991;64:1057-1068.

19. Offermanns S, Toombs CF, Hu YH, Simon MI. Defective platelet-activation in Gaq-deficient mice. Nature. 1997;389:183-186. 
20. Keuren JFW, Wielders SJ, Ulrichts H, Hackeng T, Deckmyn H, Heemskerk JWM, Bevers E, Lindhout T. Synergistic effect of thrombin on collagen-induced platelet procoagulant activity is mediated through protease-activated receptor-1. Arterioscler Thromb Vasc Biol. 2005;25:14991505.

21. De Candia E, de Cristofaro R, De Marco L, Mazzucato M, Picozzi M, Landolfi R. Thrombin interaction with platelet GPlb, role of the heparin binding domain. Thromb Haemost. 1997;77:735-740.

22. Jin J, Kunapoli SP. Coactivation of two different $G$ protein-coupled receptors is essential for ADP-induced platelet aggregation. Proc Natl Acad Sci USA. 1998;95:8070-8074.

23. Leon C, Hechler B, Freund M, Eckly A, Vial C, Ohlmann P, Dierich A, LeMeur M, Cazenave JP, Gachet $C$. Defective platelet aggregation and increased resistance to thrombosis in purinergic $\mathrm{P}_{2} \mathrm{Y}_{1}$ receptor-null mice. J Clin Invest. 1999;104:1731-1737.

24. Kunapuli SP, Dorsam RT, Kim S, Quinton TM. Platelet purinergic receptors. Curr Opin Pharmacol. 2003;3:175-180.

25. Narumiya S, Sugimoto Y, Ushikubi F. Prostanoid receptors: structures, properties, and functions. Physiol Rev. 1999;79:1193-1226.

26. Paul BZS, Jin JG, Kunapuli SP. Molecular mechanism of thromboxane $A_{2}$-induced platelet aggregation: essential role for P2T $_{A C}$ and $\alpha 2 A$ receptors. J Biol Chem. 1999;274:29108-29114.

27. Berridge MJ. Inositol trisphosphate and calcium signaling. Nature. 1993;361:315-325.

28. Sage SO. Calcium entry mechanisms in human platelets. Exp Physiol. 1997;82:807-823.

29. Van Gorp RMA, Feijge MAH, Vuist WMJ, Rook MB, Heemskerk JWM. Irregular spiking in free calcium concentration in human platelets. Regulation by modulation of the inositol trisphosphate receptors. Eur J Biochem. 2002;269:1543-1552.

30. Cavallini L, Coassin M, Borean A, Alexandre A. Prostacyclin and sodium nitroprusside inhibit the activity of the platelet inositol 1,4,5-trisphosphate receptor and promote its phosphorylation. J Biol Chem. 1996;271:5545-5551.

31. Keularts IMLW, van Gorp RMA, Feijge MAH, Vuist MWJ, Heemskerk JWM. $\alpha_{2 A}$-Adrenergic receptor stimulation potentiates calcium release in platelets by modulating cAMP levels. J Biol Chem. 2000;275:1763-1772.

32. Rosado JA, Sage SO. A role for the actin cytoskeleton in the initiation and maintenance of storemediated calcium entry in human platelets. Trends Cardiovasc Med. 2000;10:327-332.

33. Den Dekker E, Molin DGM, Breikers G, van Oerle R, Akkerman JWN, van Eys GJJM, Heemskerk JWM. Expression of transient receptor potential mRNA isoforms and $\mathrm{Ca}^{2+}$ influx in differentiating human stem cells and platelets. Biochim Biophys Acta. 2001;1539:243-255.

34. Luik RM, Wu MM, Buchanan J, Lewis RS. The elementary unit of store-operated $\mathrm{Ca}^{2+}$ entry: local activation of CRAC channels by STIM1 at ER-plasma membrane junctions. J Cell Biol. 2006;174:815-825.

35. Heemskerk JWM, Bevers EM, Lindhout T. Platelet activation and blood coagulation. Thromb Haemost. 2002;88:186-193.

36. Chrzanowska-Wodnicka M, Smyth SS, Schoenwaelder SM, Fischer TH, White GC. Rap1b is required for normal platelet function and hemostasis in mice. J Clin Invest. 2005;115:680-687.

37. Watson SP, Auger JM, McCarty OJ, Pearce AC. GPVI and integrin $\alpha$ llb $\beta 3$ signaling in platelets. J Thromb Haemost. 2005;3:1752-1762.

38. Swords NA, Mann KG. The assembly of the prothrombinase complex on adherent platelets. Arterioscler Thromb. 1993;13:1602-1612.

39. Daniel JL, Dangelmaier C, Jin JG, Kim YB, Kunapuli SP. Role of intracellular signaling events in ADP-induced platelet aggregation. Thromb Haemost. 1999;82:1322-1326.

40. Lova P, Paganini S, Sinigaglia F, Balduini C, Torti M. A Gi-dependent pathway is required for activation of the small GTPase rap1b in human platelets. J Biol Chem. 2002;277:12009-12015.

41. Rittenhouse SE. Phosphoinositide 3-kinase activation and platelet function. Blood. 1996;88:4401-4414. 
42. Koyasu S. The role of PI3K in immune cells. Nat Immunol. 2003;4:313-319.

43. Van der Meijden PEJ, Feijge MAH, Giesen PLA, Huijberts M, van Raak EPM, Heemskerk JWM. Platelet $P 2 Y_{12}$ receptors enhance signaling towards procoagulant activity and thrombin generation: a study with healthy subjects and patients at thrombotic risk. Thromb Haemost. 2005;93:1128-1137.

44. Baird TR, Walsh PN. The interaction of factor Xla with activated platelets but not endothelial cells promotes the activation of factor IX in the consolidation phase of blood coagulation. J Biol Chem. 2002;277:38462-38467.

45. Zwaal RFA, Schroit AJ. Pathophysiological implications of membrane phospholipid asymmetry in blood cells. Blood. 1997;89:1121-1132.

46. Williamson P, Bevers EM, Smeets EF, Comfurius P, Schlegel RA, Zwaal RFA. Continuous analysis of the mechanism of activated transbilayer movement in platelets. Biochemistry. 1995;34:10448-10455.

47. Bevers EM, Comfurius P, Dekkers DW, Zwaal RFA. Lipid translocation across the plasma membrane of mammalian cells. Biochim Biophys Acta. 1999;1439:317-330.

48. Daleke DL. Phospholipid flippases. J Biol Chem. 2007;282:821-825.

49. Zwaal RF, Comfurius P, Bevers EM. Surface exposure of phosphatidylserine in pathological cells. Cell Mol Life Sci 2005;62:971-988.

50. Van Dieijen G, Tans G, Rosing J, Hemker HC. The role of phospholipid and factor VIIla in the activation of bovine factor X. J Biol Chem. 1981;256:3433-3442.

51. Rosing J, Tans G, Govers Riemslag JW, Zwaal RFA, Hemker HC. The role of phospholipids and factor Va in the prothombinase complex J Biol Chem. 1980;255:274-283.

52. Rosing J, Bevers EM, Comfurius P, Hemker HC, van Dieijen G, Weiss HJ, Zwaal RFA. Impaired factor $\mathrm{X}$ and prothrombin activation associated with decreased phospholipid exposure in platelets from a patient with Scott syndrome. Blood. 1985;65:1557-1561.

53. Sims J, Wiedmer T, Esmon CT, Weiss HJ, Shattil SJ. Assembly of the platelet prothrombinase complex is linked to vesiculation of the platelet plasma membrane. Studies in Scott syndrome, an isolated defect in platelet procoagulant activity. J Biol Chem. 1989;264:17049-17057.

54. Dachary-Prigent J, Pasquet JM, Fressinaud E, Toti F, Freyssinet JM. Aminophospholipid exposure, microvesiculation and abnormal protein tyrosine phosphorylation in the platelets of a patient with Scott syndrome: a study using physiologic agonists and local anaesthetics. $\mathrm{Br} \mathrm{J}$ Haematol. 1997;99:959-967.

55. Martinez MC, Martin S, Toti F, Fressinaud E, Dachary-Prigent J, Meyer D, Freyssinet JM. The significance of capacitative $\mathrm{Ca}^{2+}$ entry in the regulation of phosphatidylserine expression at the surface of stimulated cells. Biochemistry. 1999;38:10092-10098.

56. Wolfs JL, Wielders SJ, Comfurius P, Lindhout T, Giddings JC, Zwaal RFA, Bevers EM. Reversible inhibition of the platelet procoagulant response through manipulation of the Gardos channel. Blood. 2006;108:2223-2228.

57. Monroe DM, Hoffman M, Roberts HR. Platelets and thrombin generation. Arterioscler Thromb Vasc Biol. 2002;22:1381-1389.

58. Lisman T, Adelmeijder J, Cauwenberghs S, van Pampus ECM, Heemskerk JWM, de Groot PG. Recombinant factor VIla enhances platelet adhesion and activation under flow conditions at normal and reduced platelet count. J Thromb Haemost. 2005;3:742-751.

59. Zillmann A, Luther T, Muller I, Kotzsch M, Spannagl M, Kauke T, Oelschlagel U, Zahler S, Engelmann B. Platelet-associated tissue factor contributes to the collagen-triggered activation of blood coagulation. Biochem Biophys Res Commun. 2001;281:603-609.

60. Novotny WF, Girard TJ, Miletich JP, Broze GJ. Platelets secrete a coagulation inhibitor functionally and antigenically similar to the lipoprotein associated coagulation inhibitor. Blood. 1988;72:2020-2025.

61. Butenas S, Bouchard BA, Brummel-Ziedins KE, Parhami-Seren B, Mann KG. Tissue factor activity in whole blood. Blood. 2005;105:2764-2770. 
62. Lindhout T, Blezer R, Schoen P, Nordfang O, Reutelingsperger C, Hemker HC. Activation of factor $X$ and its regulation by tissue factor pathway inhibitor in small-diameter capillaries lined with human endothelial cells. Blood. 1992;79:2909-2916.

63. Baglia FA, Badellino $\mathrm{KO}$, Li CQ, Lopez JA, Walsh $\mathrm{PN}$. Factor $\mathrm{XI}$ binding to the platelet glycoprotein Ib-IX-V complex promotes factor XI activation by thrombin. J Biol Chem. 2002;277:1662-1668.

64. Bradford HN, Pixley RA, Colman RW. Human factor XII binding to the glycoprotein Ib-IX-V complex inhibits thrombin-induced platelet aggregation. J Biol Chem. 2000;275:22756-22763.

65. Byzova TV, Plow EF. Networking in the hemostatic system: integrin $\alpha$ llb $\beta 3$ binds prothrombin and influences its activation. J Biol Chem. 1997;272:27183-27188.

66. Dale GL. Coated-platelets: an emergic component of the procoagulant response. J Thromb Haemost. 2005;3

67. Bouchard BA, Catcher CS, Thrash BR, Adida C, Tracy PB. Effector cell protease receptor-1, a platelet activation-dependent membrane protein, regulates prothrombinase-catalyzed thrombin generation. J Biol Chem. 1997;272:9244-9251.

68. Larson PJ, Camire RM, Wong D, Fasano NC, Monroe DM, Tracy PB, High KA. Structure/function analyses of recombinant variants of human factor $\mathrm{Xa}$, factor $\mathrm{Xa}$ incorporation into prothrombinase on the thrombin-activated platelet surface is not mimicked by synthetic phospholipid vesicles. Biochemistry. 1998;37:5029-5038.

69. Rudolph AE, Porche-Sorbet R, Miletich JP. Substitution of asparagine for arginine 347 of recombinant factor Xa markdly reduces factor Va binding. Biochemistry. 2000;39:2861-2867.

70. Briedé JJ, Heemskerk JWM, van 't Veer C, Hemker HC, Lindhout T. Contribution of plateletderived factor $\mathrm{Va}$ to thrombin generation on immobilized collagen- and fibrinogen-adherent platelets. Thromb Haemost. 2001;85:509-513.

71. Zaman GJR, Conway EM. The elusive factor Xa receptor: failure to detect transcripts that correspond to the published sequence of EPR1. Blood. 2000;96:145-148.

72. Kulkarni S, Jackson SP. Platelet factor XIII and calpain negatively regulate integrin $\alpha$ llb $\beta 3$ adhesive function and thrombus growth. J Biol Chem. 2004;279:30697-30706.

73. Heemskerk JWM, Vuist WMJ, Feijge MAH, Reutelingsperger CPM, Lindhout T. Collagen but not fibrinogen surfaces induce bleb formation, exposure of phosphatidylserine and procoagulant activity of adherent platelets. Evidence for regulation by protein tyrosine kinase-dependent $\mathrm{Ca}^{2+}$ responses. Blood. 1997;90:2615-2625.

74. Siljander P, Farndale RW, Feijge MAH, Comfurius P, Kos S, Bevers EM, Heemskerk JWM. Platelet adhesion enhances the glycoprotein VI-dependent procoagulant response: involvement of p38 MAP kinase and calpain. Arterioscler Thromb Vasc Biol. 2001;21:618-627.

75. Bevers EM, Comfurius P, Zwaal RF. Changes in membrane phospholipid distribution during platelet activation. Biochim Biophys Acta. 1983;736:57-66.

76. Andersen H, Greenberg DL, Fujikawa K, Xu WF, Chung DW, Davie EW. Protease-activated receptor 1 is the primary mediator of thrombin-stimulated platelet procoagulant activity. Proc Natl Acad Sci USA. 1999;96:11189-11193.

77. Ramström S, Ranby M, Lindahl TL. Platelet phosphatidylserine exposure and procoagulant activity in clotting whole blood: different effects of collagen, TRAP and calcium ionophore A23187. Thromb Haemost. 2003;89:132-141.

78. De Marco L, Mazzucato M, Masotti A, Fenton JW, 2nd, Ruggeri ZM. Function of glycoprotein Ib $\alpha$ in platelet activation induced by $\alpha$-thrombin. J Biol Chem. 1991;266:23776-23783.

79. Dörmann D, Clemetson KJ, Kehrel B. The GPIb thrombin-binding site is essential for thrombininduced platelet procoagulant activity. Blood. 2000;86:2469-2478.

80. Jandrot-Perrus M, Rendu F, Caen JP, Levy-Toledano S, Guillin MC. The common pathway for $\alpha$ - and $\gamma$-thrombin-induced platelet activation is independent of GPIb: a study of Bernard-Soulier platelets. Br J Haematol. 1990;75:385-392.

81. Ruggeri ZM, Dent JA, Saldívar E. Contribution of distinct adhesive interactions to platelet aggregation in flowing blood. Blood. 1999;94:172-178. 
82. Wu YP, Vink T, Schiphorst M, van Zanten GH, IJsseldijk MJW, de Groot PG, Sixma JJ. Platelet thrombus formation on collagen at high shear rates is mediated by von Willebrand factorglycoprotein lb interaction and inhibited by von Willebrand factor-glycoprotein Ilb/llla interaction. Arterioscler Thromb Vasc Biol. 2000;20:1661-1667.

83. Jackson SP, Mistry N, Yuan YP. Platelets and the injured vessel wall: "rolling into action". Focus on glycoprotein $\mathrm{Ib} / \mathrm{V} / \mathrm{IX}$ and the platelet cytoskeleton. Trends Cardiovasc Med. 2000;10:192-197.

84. Kuijpers MJE, Schulte V, Oury C, Lindhout T, Broers JL, Hoylaerts MF, Nieswandt B, Heemskerk JWM. Facilitating roles of murine platelet glycoprotein $\mathrm{lb}$ and $\alpha$ llb $\beta 3$ in phosphatidylserine exposure during vWF-collagen-induced thrombus formation. J Physiol. 2004;558:403-415.

85. Lecut C, Schoolmeester A, Kuijpers MJE, Broers JL, van Zandvoort MAM, Vanhoorelbeke K, Deckmyn H, Jandrot-Perrus M, Heemskerk JWM. Principal role of glycoprotein VI in $\alpha 2 \beta 1$ and $\alpha$ llb $\beta 3$ activation during collagen-induced thrombus formation. Arterioscler Thromb Vasc Biol. 2004;24:1727-1733.

86. Auger JM, Kuijpers MJE, Senis YA, Watson SP, Heemskerk JWM. Adhesion of human and mouse platelets to collagen under shear: a unifying model. FASEB J. 2005;19:825-827.

87. Nieswandt B, Watson SP. Platelet-collagen interaction: is GPVI the central receptor? Blood. 2003;102:449-461.

88. Remijn JA, Wu YP, Heninga EH, IJsseldijk MJW, van Willigen G, de Groot PG, Sixma JJ, Nurden AT, Nurden P. Role of ADP receptor P2Y 12 in platelet adhesion and thrombus formation in flowing blood. Arterioscler Thromb Vasc Biol. 2002;22:686-691.

89. Kato K, Kanaji T, Russell S, Kunicki TJ, Furihata K, Kanaji S, Marchese P, Reininger A, Ruggeri $\mathrm{ZM}$, Ware J. The contribution of glycoprotein $\mathrm{VI}$ to stable platelet adhesion and thrombus formation illustrated by targeted gene deletion. Blood. 2003;102:170-1707.

90. Kuijpers MJE, Schulte V, Bergmeier W, Lindhout T, Brakebusch C, Offermanns S, Fässler R, Heemskerk JWM, Nieswandt B. Complementary roles of glycoprotein VI and $\alpha 2 \beta 1$ integrin in collagen-induced thrombus formation in flowing whole blood ex vivo. FASEB J. 2003;17:685687.

91. Kuijpers MJE, Pozgajova M, Cosemans JMEM, Munnix ICA, Eckes B, Nieswandt B, Heemskerk JWM. Unidentified role of integrin $\alpha 2 \beta 1$ in thrombus stabilization and embolization. Thromb Haemost. 2007; submitted.

92. Goto S, Tamura N, Ishida H, Ruggeri ZM. Dependence of platelet thrombus stability on sustained glycoprotein Ilb/llla activation through adenosine 5-diphosphate receptor stimulation and cylcic calcium signaling. J Am Coll Cardiol. 2006;47:155-162.

93. Cosemans JMEM, Munnix ICA, Wetzker R, Heller L, Jackson SP, Heemskerk JWM. Continuous signaling via PI3K isoforms $\beta$ and $\gamma$ is required for platelet ADP receptor function in dynamic thrombus stabilization. Blood. 2006;108:3045-3052.

94. Heemskerk JWM, Kuijpers MJE, Munnix ICA, Siljander PRM. Platelet collagen receptors and coagulation. A characteristic platelet response as possible target for antithrombotic treatment. Trends Cardiovasc Med. 2005;15:86-92.

95. Lecut C, Feijge MAH, Cosemans JMEM, Jandrot-Perrus M, Heemskerk JWM. Fibrillar type I collagens enhance platelet-dependent thrombin generation via glycoprotein VI with direct support of $\alpha 2 \beta 1$ but not $\alpha$ llb $\beta 3$ integrin. Thromb Haemost. 2005;94:107-114.

96. Kuijpers MJE, Nieuwenhuys CMA, Feijge MAH, Kloots W, Giesen PLA, Jerling JC, oude Egbrink MGA, Heemskerk JWM. Regulation of tissue factor-induced coagulation and platelet aggregation in flowing whole blood. Thromb Haemost. 2005;93:97-105.

97. Oude Egbrink MGA, van Gestel MA, Broeders MAW, Tangelder GJ, Heemskerk JWM, Reneman RS, Slaaf DW. Regulation of microvascular thromboembolism in vivo. Microcirculation. 2005;12:287-300.

98. Kuijpers MJE. Platelet receptors and procoagulant activity in thrombus formation. Ph D Thesis, Maastricht University, Maastricht, The Netherlands, ISBN-10: 90-5278-517-1. 2006. 
99. Ni H, Ramakrishnan V, Ruggeri ZM, Papalia JM, Phillips DR, Wagner DD. Increased thrombogenesis and embolus formation in mice lacking glycoprotein V. Blood. 2001;98:368-373.

100. Van Gestel MA, Heemskerk JWM, Slaaf DW, Heijnen VVT, Reneman RS, oude Egbrink MGA. In vivo blockade of platelet $A D P$ receptor $\mathrm{P}_{2} \mathrm{Y}_{12}$ reduces embolus and thrombus formation but not thrombus stability. Arterioscler Thromb Vasc Biol. 2003;23:518-523.

101. Falati S, Gross P, Merrill-Skoloff G, Furie BC, Furie B. Real-time in vivo imaging of platelets, tissue factor and fibrin during arterial thrombus formation in the mouse. Nat Med. 2002;10:11751180.

102. Massberg S, Gawaz M, Güner S, Schulte V, Konrad I, Zohlhöfer D, Heinzmann U, Nieswandt B. A crucial role of glycoprotein VI for platelet recruitment to the injured arterial wall in vivo. J Exp Med. 2003;197:41-49.

103. Nieswandt B, Schulte V, Bergmeier W, Mokhtari-Nejad R, Rackebrandt K, Cazenave JP, Ohlmann P, Gachet C, Zirngibl H. Long-term antithrombotic protection by in vivo depletion of platelet glycoprotein VI in mice. J Exp Med. 2001;193:459-469.

104. Grüner S, Prostredna M, Koch M, Miura Y, Schulte V, Jung SM, Moroi M, Nieswandt B. Relative antithrombotic effect of soluble GPVI dimer compared with anti-GPVI antibodies in mice. Blood. 2005;105:1492-1499.

105. Dubois C, Panicot-Dubois L, Merrill-Skoloff G, Furie B, Furie BC. Glycoprotein VI-dependent and -independent pathways of thrombus formation in vivo. Blood. 2006;107:3902-3906.

106. Mangin P, Yap CL, Nonne C, Sturgeon SA, Goncalves I, Yuan Y, Schoenwaelder SM, Wright $\mathrm{CE}$, Lanza F, Jackson SP. Thrombin overcomes the thrombosis defect associated with platelet GPVI/FcR $\gamma$ deficiency. Blood. 2006;107:4346-4353.

107. Furihata K, Clemetson KJ, Deguchi H, Kunicki TJ. Variation in human platelet glycoprotein VI content modulates glycoprotein VI-specific prothrombinase activity. Arterioscler Thromb Vasc Biol. 2001;21:1857-1863.

108. Den Dekker E, van Abel M, van der Vuurst H, van Eys G, Akkerman JWN, Heemskerk JWM. Cell-to-cell variability in the differentiation program of human megakaryocytes. Biochim Biophys Acta. 2003;1643:85-94.

109. Den Dekker E, Gorter G, Van der Vuurst H, Heemskerk JWM, Akkerman JWN. Biogenesis of Gprotein mediated calcium signaling in human megakaryocytes. Thromb Haemost. 2001;86:1106-1113.

110. Briedé JJ, Heemskerk JWM, Hemker HC, Lindhout T. Heterogeneity in microparticle formation and exposure of anionic phospholipids at the plasma membrane of single adherent platelets. Biochim Biophys Acta. 1999;1451:163-172.

111. Dale GL, Friese P, Batar P, Hamilton SF, Reed GL, Jackson KW, Clemetson KJ, Alberio L. Stimulated platelets use serotonin to enhance their retention of procoagulant proteins on the cell surface. Nature. 2002;415:175-179.

112. Kempton CL, Hoffman M, Roberts HR. Platelet heterogeneity: variation in coagulation complexes on platelet subpopulations. Arterioscler Thromb Vasc Biol. 2005;25:861-866.

113. Nesbitt WS, Giuliano S, Kulkarni S, Dopheide SM, Harper IS, Jackson SP. Intercellular calcium communication regulates platelet aggregation and thrombus growth. J Cell Biol. 2003;160:11511161.

114. Haimovich B, Lipfert L, Brugge JS, Shattil SJ. Tyrosine phosphorylation and cytoskeletal reorganization in platelets are triggered by interaction of integrin receptors with their immobilized ligands. J Biol Chem. 1993;268:15868-15877.

115. Goncalves I, Hughan SC, Schoenwaelder SM, Yap CL, Yuan J, Jackson SP. Integrin allbß33dependent calcium signals regulate platelet-fibrinogen interactions under flow. J Biol Chem. 2003;278:34812-34822.

116. Alberio L, Safa O, Clemetson KJ, Esmon CT, Dale GL. Surface expression and functional characterization of $\alpha$-granule factor $V$ in human platelets: effects of ionophore $A 23187$, thrombin, collagen, and convulxin. Blood. 2000;95:1694-1702. 



\section{Chapter 2}

\section{Store-mediated calcium entry in the regulation of phosphatidylserine exposure in blood cells from Scott patients}

Imke C. A. Munnix, Marjan Harmsma, John C. Giddings, Peter W. Collins, Marion A. H.

Feijge, Paul Comfurius, Johan W. M. Heemskerk and Edouard M. Bevers

Thromb Haemost 2003; 89: 687-95

Reprinted with permission 


\section{Abstract}

The Scott syndrome is a bleeding disorder, characterized by impaired surface exposure of procoagulant phosphatidylserine (PS) on platelets and other blood cells, following activation with $\mathrm{Ca}^{2+}$-elevating agents. Since store-mediated $\mathrm{Ca}^{2+}$ entry (SMCE) forms an important part of the $\mathrm{Ca}^{2+}$ response in various blood cells, it has been proposed that deficiencies in $\mathrm{Ca}^{2+}$ entry may relate to the impaired $\mathrm{PS}$ exposure in the Scott syndrome. Here, we have tested this hypothesis by investigating the relationship between $\mathrm{Ca}^{2+}$ fluxes and PS exposure in platelets as well as B-lymphoblasts derived from the original Scott patient (M.S.), a newly identified Welsh patient (V.W.) with similar bleeding symptoms, and two control subjects. Procoagulant activity of V.W. platelets in suspension, measured after stimulation with collagen/thrombin or Ca-ionophore, ionomycin, resulted in $52 \%$ or $17 \%$, respectively, compared to that of correspondingly activated control platelets. Procoagulant activity of V.W. erythrocytes treated with ionomycin resulted in less than $6 \%$ of the activity of control erythrocytes. Single-cell $\mathrm{Ca}^{2+}$ responses of M.S. and V.W. platelets, adhering to collagen, were similar to those of platelets from control subjects, while PS exposure was reduced to $7 \%$ and $15 \%$, respectively, compared to controls. Stimulation of non-apoptotic B-lymphoblasts derived from both patients and controls with ionomycin or agents causing $\mathrm{Ca}^{2+}$ mobilization and SMCE, resulted in similar $\mathrm{Ca}^{2+}$ responses. However, in lymphoblasts from M.S. and V.W. $\mathrm{Ca}^{2+}$-induced PS exposure was reduced to $7 \%$ and $13 \%$ of the control lymphoblasts, respectively. We conclude that $i$. patient V.W. is a new case of Scott syndrome, ii. $\mathrm{Ca}^{2+}$ entry in the platelets and lymphoblasts from both Scott patients is normal, and iii. elevated $\left[\mathrm{Ca}^{2+}\right]_{i}$ as caused by SMCE is not sufficient to trigger PS exposure.

\section{Introduction}

Cell surfaces containing anionic phospholipids, in particular phosphatidylserine (PS), play a pivotal role in blood coagulation. These procoagulant lipid membranes form a catalytic surface for the assembly and proper conformation and juxtaposition of the factor $X$ and prothrombin activating enzyme complexes. Formation of these complexes strongly accelerates the rate of thrombin formation, which is responsible for the production of a stabile fibrin clot. Cellular procoagulant lipid surfaces are mainly provided by platelets. Upon appropriate stimulation, platelets lose their asymmetric transbilayer phospholipid distribution, resulting in exposure of PS at the exterior cell surface. 
The Scott syndrome is a rare, hereditary bleeding disorder characterized by impaired surface exposure of PS at the plasma membrane of activated platelets and decreased shedding of procoagulant platelet-derived microvesicles ${ }^{1}$. The Scott phenotype, as apparent in platelets, has also been observed in erythrocytes and Epstein-Bar virus (EBV)-transformed B-lymphocytes ${ }^{2-4}$, indicating a cell typeindependent trait. Weiss et al., in 1979, were the first to identify a patient (M.S.) with this disorder ${ }^{1}$. One year later, a report was published on ten individuals from three unrelated Welsh families, who also suffered from an unusual bleeding disorder ${ }^{5}$. The latter patients have not been studied extensively since then, but the original data suggest that their bleeding abnormality might be similar or possibly identical to the Scott syndrome. Later, also a French family has been found of which the propositus had platelets deficient in PS exposure and microvesiculation, but not in secretion and aggregation ${ }^{6-8}$. Recently, a colony of German shepherd dogs was discovered with a hereditary bleeding disorder and deficient PS exposure in platelets, characteristic of Scott syndrome ${ }^{9}$. The inability of platelets and other blood cells to scramble phospholipids, and thus expose PS, has been assigned to abnormal activity of a $\mathrm{Ca}^{2+}$-dependent phospholipid scramblase activity in the plasma membrane of these cells.

Cytosolic $\left[\mathrm{Ca}^{2+}\right]_{i}$ serves as an intracellular mediator for many extracellular signals in platelets and other cells, regulating processes such as cellular shape, secretion, growth and differentiation ${ }^{10-12}$. In earlier work with platelets, it appeared that a prolonged, high increase in $\left[\mathrm{Ca}^{2+}\right]_{i}$ is required for PS exposure, e.g. as achieved by $\mathrm{Ca}^{2+}$ ionophore, collagen receptor (glycoprotein $\mathrm{VI}$ ) stimulation ${ }^{13-15}$ or the combination of thrombin and thapsigargin ${ }^{16}$. Release of $\mathrm{Ca}^{2+}$ from intracellular stores is insufficient for full platelet activation. However, following depletion of the intracellular $\mathrm{Ca}^{2+}$ stores, a mechanism is activated which allows $\mathrm{Ca}^{2+}$ entry across the plasma membrane. This store-mediated $\mathrm{Ca}^{2+}$ entry (SMCE) from the extracellular medium is a prerequisite to reach the high $\mathrm{Ca}^{2+}$ signals required for full platelet activation ${ }^{17}$. In platelets and related cells at least a substantial part of the SMCE is mediated by plasma membrane ion channels of the Trp family ${ }^{18}$. Blocking of this $\mathrm{Ca}^{2+}$ entry process abolishes agonistinduced PS exposure ${ }^{15,19}$ and, conversely, increased $\mathrm{Ca}^{2+}$ influx in platelets is correlated with higher PS exposure ${ }^{20,21}$. Recently, Martinez et al. reported of a reduced SMCE in Blymphoblasts derived from the propositus of the French Scott family, whereas the release of $\mathrm{Ca}^{2+}$ from intracellular stores in these cells was normal ${ }^{4,22}$. Together, these observations suggest that defective store-mediated (capacitative) $\mathrm{Ca}^{2+}$ entry may be part of the Scott phenotype. However, studies on SMCE have thus far only been performed with the French Scott patient. 
In this paper, we examine the relationship between $\mathrm{Ca}^{2+}$ fluxes and exposure of procoagulant PS in the plasma membrane of both platelets and immortalized, EBVtransfected B-cells from two control subjects and two different Scott patients. We simultaneously measured $\mathrm{Ca}^{2+}$ fluxes and PS exposure in individual platelets from these patients using fluorescence imaging microscopy. In the viable, non-apoptotic population of the B-cell lines, we determined the $\mathrm{Ca}^{2+}$ responses evoked by store-depleting agonists, as well as the PS exposure by dual-label flow cytometry.

\section{Materials and methods}

\section{Materials}

Fibrillar type-1 collagen from equine tendon (Collagen reagent Horm ${ }^{\circledR}$ ) was purchased from Nycomed (Munich, Germany). Fluorescein isothiocyanate (FITC)labeled annexin $\mathrm{V}$ (Fl-annexin V) was a product from Nexins Research (Hoeven, The Netherlands). Fura-2 and Fluo-3 acetoxymethyl esters, Pluronic F-127 and Alexa Fluor 647-labeled annexin V (AF-annexin V) were purchased from Molecular Probes (Leiden, The Netherlands). Bovine serum albumin (BSA), apyrase (grade $V$ ), ionomycin, caffeine and thapsigargin were from Sigma (St. Louis, MO, USA). RPMI-glutamax I was obtained from Bio-Whittaker (Walkersville, MD, USA). Fetal calf serum and antibiotic antimycotic solution were obtained from Life Technologies (Paisly, UK), and Lymphoprep came from Nycomed Pharma AS (Oslo, Norway). Coagulation factors thrombin, prothrombin, factor $\mathrm{Xa}$ and factor $\mathrm{Va}$ were purified as described before ${ }^{23}$. Thrombin-specific chromogenic substrate, H-D-Phe-Pip-Arg-para-nitroaniline (S2238) was from Chromogenix (Mölndal, Sweden).

\section{Patients}

Clinical features of patient M.S. have been described extensively before ${ }^{24}$. Patient V.W. had presented initially at the age of 14 years with a history of excessive bleeding after dental extractions on five occasions. Dental surgery at age 22 again resulted in excessive blood loss, with a fall in haemoglobin concentration from 14.6 to $9.3 \mathrm{~g} / \mathrm{dl}$. At 34 years of age she suffered life-threatening post partum haemorrhage after an uncomplicated forceps delivery. Studies at that time revealed an isolated severe abnormality of prothrombin conversion consistent with a defective interaction between plasma and platelets or phospholipid. All other tests of haemostasis were normal ${ }^{5}$. 


\section{Platelet preparation and culturing of B-lymphoblasts}

Freshly obtained citrated blood from patients M.S., V.W. and two control subjects was shipped at $4^{\circ} \mathrm{C}$ by airmail to Maastricht (The Netherlands). Immediately upon arrival (24-48 hours later), platelets were washed and used for the experiments.

Loading of platelets with Fura-2 and washing procedures have been described elsewhere ${ }^{25,26}$. Washed platelets were resuspeded in Hepes buffer (10 mM Hepes, 136 $\mathrm{mM} \mathrm{NaCl}, 2.7 \mathrm{mM} \mathrm{KCl}, 2 \mathrm{mM} \mathrm{MgCl} 2,0.1 \% \mathrm{BSA}$ and $0.1 \%$ glucose, adjusted at $\mathrm{pH} 7.45$ ) at a final concentration of $1.0 \times 10^{8}$ platelets $/ \mathrm{ml}$. Erythrocytes were washed 3 times in the same Hepes buffer $(\mathrm{pH} 7.45)$ and resuspended at $1 \times 10^{8}$ cells $/ \mathrm{ml}$.

Data of platelets from M.S. presented in this study were obtained in 1996 on the last occasion that we received blood from this patient. Since M.S. deceased that same year, there was no opportunity to study the platelets from this patient with those from patient V.W. simultaneously. Experiments with blood cells from patient V.W. were performed in 2002.

EBV-transformed B-cells from M.S. and a control subject were available from previous studies ${ }^{27}$. EBV-transformed B-cells from patient V.W. were prepared by Professor E.G.D. Tuddenham (Imperial College School of Medicine, London). Before use, the EBV-infected cells were expanded in RPMI-glutamax I culture medium containing $10 \%(\mathrm{v} / \mathrm{v})$ fetal calf serum and antibiotic antimycotic solution. Cells were kept at $37^{\circ} \mathrm{C}$ in a humidified atmosphere with $5 \% \mathrm{CO}_{2}$, and were sub-cultured in 3 volumes fresh medium every 2 or 3 days. Data of EBV-transformed B-lymphocytes from both patients and two corresponding controls were collected from experiments performed in 2002.

\section{Procoagulant activity of platelets and erythrocytes in suspension}

Prothrombinase activity of washed platelets in suspension, either activated for 15 min with collagen $(10 \mu \mathrm{g} / \mathrm{ml})$ plus thrombin $(4 \mathrm{nM})$ or for 5 min with ionomycin $(1 \mu \mathrm{M})$, was determined by measuring the rate of conversion of prothrombin to thrombin by the enzyme complex factor Xa-factor $\mathrm{Va}$, as described before ${ }^{26}$. The assay conditions were: $3 \times 10^{6}$ platelets $/ \mathrm{ml}, 3 \mathrm{mM} \mathrm{CaCl}_{2}, 3 \mathrm{nM}$ factor $\mathrm{Xa}, 6 \mathrm{nM}$ factor $\mathrm{Va}$ and $4 \mu \mathrm{M}$ prothrombin (all final concentrations). Chromogenic thrombin substrate S2238 (250 $\mu \mathrm{M})$ was used to determine the amount of thrombin formed. To measure procoagulant activity of erythrocytes, washed cells at a concentration of $2 \times 10^{8} / \mathrm{ml}$ were incubated with $5 \mu \mathrm{M}$ ionomycin in the presence of $1 \mathrm{mM} \mathrm{CaCl}_{2}$ for $60 \mathrm{~min}$. Samples from this incubation are 
diluted to a cell count of $10^{7} / \mathrm{ml}$, and prothrombinase activity was measured using the conditions described above.

\section{Dual measurement of $\left[\mathrm{Ca}^{2+}\right]_{i}$ and phosphatidylserine exposure by fluorescence imaging microscopy}

Intracellular $\mathrm{Ca}^{2+}$ and PS exposure in was determined by a quasi-simultaneous measurement of fluorescence from Fura-2 and Fl-annexin $\mathrm{V}$ using a combined fluorescence imaging and microphotometric system as described previously ${ }^{15}$. Changes in fluorescence were measured in single platelets after 25 minutes adhering to a collagen-coated coverslip. The incubation chamber contained $5 \times 10^{7}$ Fura-2-loaded platelets in $300 \mu \mathrm{l}$ Hepes buffer with $2 \mathrm{mM} \mathrm{CaCl}_{2}$ and $0.5 \mu \mathrm{g} / \mathrm{ml} \mathrm{Fl-annexin} \mathrm{V.}$ Fluorescence of about 100 cells in three or more microscopic fields was measured. Conversion of Fura-2 fluorescence ratio to levels of $\left[\mathrm{Ca}^{2+}\right]$ i was made as described before $^{17}$. During the measurements in 1996 (patient M.S. and control 1) the optical pathway was slightly different from that used in 2002 (patient V.W. and control 2), resulting in slightly different calibration values of $\left[\mathrm{Ca}^{2+}\right]_{i}$. Platelets were considered to be elevated in $\left[\mathrm{Ca}^{2+}\right]_{i}$ when their Fura-2 ratio was increased with 0.2 compared to basal, corresponding to a rise of about $85 \mathrm{nM}$; annexin $\mathrm{V}$ positivity was defined as all localized fluorescence in the fluorescein channel of $>30$ pixels.

\section{Dual measurement of $\left[\mathrm{Ca}^{2+}\right]_{i}$ and phosphatidylserine exposure by flow cytometry}

Cultured EBV-transformed B-lymphocytes derived from patients and control subjects were centrifuged at $700 \mathrm{~g}$ for $10 \mathrm{~min}$, and resuspended in Hepes buffer $\mathrm{pH} 7.45$ and the cell count was adjusted to $10^{6} \mathrm{cells} / \mathrm{ml}$. Washed B-lymphoblasts were loaded with $3 \mu \mathrm{M}$ Fluo-3 acetoxymethyl ester in the presence of $1 \mathrm{mg} / \mathrm{ml}$ Pluronic F-127 at room temperature for $30 \mathrm{~min}$. Loaded cells were activated with $10 \mu \mathrm{M}$ ionomycin ( $5 \mathrm{~min}), 1 \mu \mathrm{M}$ thapsigargin $(5 \mathrm{~min})$, or $10 \mathrm{mM}$ caffeine $(10 \mathrm{~min})$. Activations were carried out in the presence of either $\mathrm{CaCl}_{2}(2 \mathrm{mM})$ or EGTA $(2 \mathrm{mM})$ to study total $\mathrm{Ca}^{2+}$ responses and $\mathrm{Ca}^{2+}$ mobilization separately. Where indicated, the loaded cells were pre-incubated with AFannexin V, as described by the manufacturer, to monitor PS exposure. After activation, Fluo-3 and Alexa Fluor 647 fluorescence were simultaneously measured using a FACScan flow cytometer, and Cell-Quest software (Becton-Dickinson, CA, USA). For analysis, viable B-cells were gated based on their forward and side scatter, to exclude apoptotic cells and cellular fragments. Per assay, a minimum of 5000 events was counted. Control measurements were always run with unlabeled/stimulated as well as 
labeled/unstimulated cells. Green (Fluo-3) and red (Alexa Fluor 647) fluorescence intensities were expressed as arbitrary units. Dot-plots of fluorescence versus forward scatter of control cells in the absence of fluorescent annexin $V$ were used to define the region containing $99 \%$ of the annexin V-negative cells. Events outside this region were considered to be positive. List-mode data were analyzed using WinMDI 2.8 software (http://facs.scripps.edu).

\section{Results}

\section{Procoagulant activity of platelets and erythrocytes in suspension}

First we established the Scott syndrome phenotype of the Welsh patient, V.W. As shown in Table 1, washed platelets of this patient in suspension activated by collagen plus thrombin resulted in a prothrombinase activity of $52 \%$ of that achieved with similarly activated platelets from the control subject, whereas stimulation with ionomycin induced a procoagulant response of only $17 \%$ of that of ionomycin-treated control platelets. Considering the normal levels of coagulation factors and normal platelet aggregation ${ }^{5}$, these findings confirm the phenotype of a Scott syndrome of patient V.W. This was further substantiated by the observation that washed erythrocytes of V.W., treated with ionomycin and $\mathrm{Ca}^{2+}$, were deficient in forming a procoagulant surface: prothrombinase activity was $5.6 \pm 1 \%$ (mean $\pm S D, n=5$ ) of that of control erythrocytes. When the prothrombinase activity of completely lysed cell preparations (obtained by sonication) of either platelets or erythrocytes was measured, there was no appreciable difference between patients and controls. This excludes that the decreased procoagulant activity in the patient's platelets and erythrocytes is due to alterations in the overall phospholipid

Prothrombinase (nM thrombin/min)

\begin{tabular}{lllll}
\cline { 2 - 4 } Activation & Control 1 & Patient M.S. & Control 2 & Patient V.W. \\
\hline None & $136 \pm 11$ & $54 \pm 3(40 \%)$ & $130 \pm 22$ & $84 \pm 16(65 \%)$ \\
Collagen + thrombin & $358 \pm 37$ & $119 \pm 44(33 \%)$ & $336 \pm 10$ & $176 \pm 30(52 \%)$ \\
lonomycin & $1159 \pm 247$ & $247 \pm 71(18 \%)$ & $1172 \pm 6$ & $200 \pm 6(17 \%)$
\end{tabular}

Table 1 Prothrombinase activity of suspensions of platelets from control subjects and Scott patients. Values presented are means $\pm S D$ of three independent measurements performed in 1996 for patient M.S and in 2002 for patient V.W., each with their corresponding control. In brackets is given the activity expressed as a percentage of the correspondingly treated control platelets. It should be emphasized that due to the time between collection of the blood and the prothrombinase measurement (24-48 hrs), the prothrombinase activity of the non-stimulated platelets is slightly increased compared to that of freshly prepared platelet suspensions. 
composition, i.e. a reduced content of PS.

Finally, similar to previous findings on the morphology of the erythrocytes of propositus M.S. ${ }^{2}$, the red cells of V.W. did not change into echinocytes after treatment with ionomycin and were unable to produce microvesicles.

\section{Relation between calcium responses and phosphatidylserine exposure of single platelets}

Fluorescence video microscopic imaging was used to examine whether the $\mathrm{Ca}^{2+}$ fluxes and PS exposure of the platelets from the patients differ from those of control subjects. In one set of experiments, Fura-2-loaded platelets from M.S. were compared with the simultaneously collected platelets from control 1. In a later set of experiments,

A Control 1

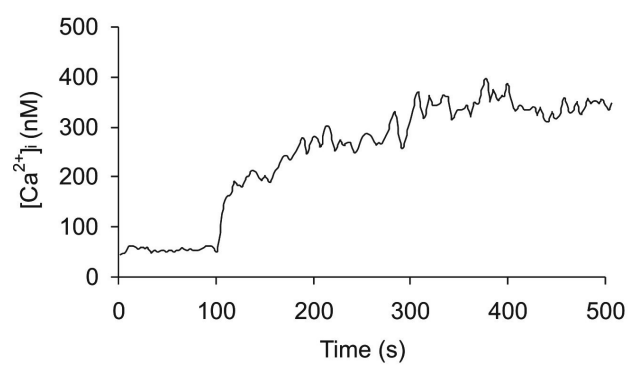

B Patient MS

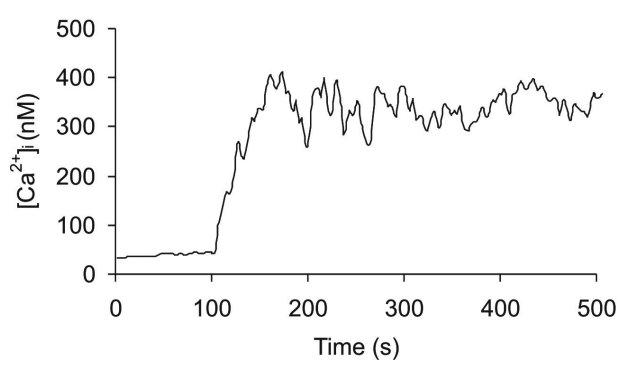

Control 2

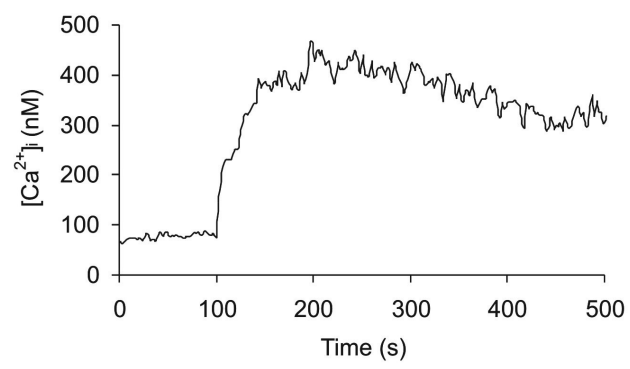

\section{Patient VW}

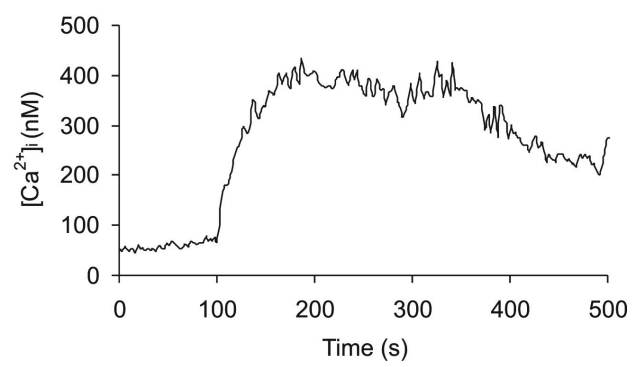

Figure 1 Collagen-induced $\mathrm{Ca}^{2+}$ responses of single platelets from control subjects and Scott patients. Fura-2-loaded platelets were allowed to adhere to collagen fibers in the presence of $\mathrm{CaCl}_{2}(2$ $\mathrm{mM}$ ). Changes in Fura-2 fluorescence ratio in single platelets were measured by fluorescence video imaging microscopy. (A) Experiments were performed in 1996 with platelets from control 1 and patient M.S. (B) Experiments with platelets from control 2 and patient V.W. were carried out in 2002. Changes in Fura-2 fluorescence ratio (340/380 nm excitation) were recorded during adhesion and activation, as described in Materials and Methods. Traces are averaged overlays of single traces obtained from at least twenty platelets per subject ( $\mathrm{n} \geq 3$ incubations/subject). 
platelets from V.W. were compared with those of control 2. The platelets were allowed to interact with collagen fibers, during which glycoprotein $\mathrm{VI}$-induced changes in $\left[\mathrm{Ca}^{2+}\right]_{i}$ were measured at a single-cell level by capturing fluorescence ratio images. Patient and control platelets showed prominent increases in $\left[\mathrm{Ca}^{2+}\right]_{\mathrm{i}}$ shortly after adhesion to collagen (Figure 1). It appeared that the collagen-induced rises in $\left[\mathrm{Ca}^{2+}\right]_{i}$ in the platelets from either patient were similar in magnitude to those of the platelets from the two controls.

As the glycoprotein VI-induced increase in $\left[\mathrm{Ca}^{2+}\right]_{i}$ is a major signal in the procoagulant response, i.e. PS exposure ${ }^{19}$, we determined in the same experiment also the binding to platelets of Fl-labeled annexin $\mathrm{V}$, which binds to surface-exposed PS ${ }^{28,29}$. After $25 \mathrm{~min}$ adhesion to collagen, $40 \%$ of the activated platelets of control 1 were annexin $\mathrm{V}$ positive, in comparison to less than $3 \%$ of the platelets of Scott patient M.S. (Figure 2A). Similarly, the collagen-activated platelets from patient V.W. showed a strongly reduced PS exposure in comparison to those of control 2 , although still $8 \%$ of the patient platelets did bind $\mathrm{Fl}$-annexin $\mathrm{V}$, i.e. slightly more than observed for patient M.S. (Figure 2B). These observations confirm the Scott syndrome phenotype in patient V.W.

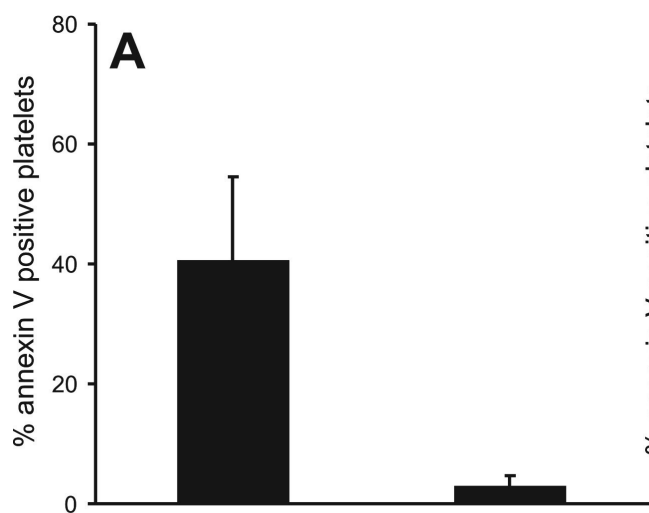

Control 1

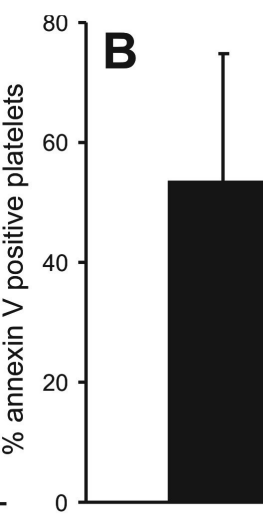

Control 2

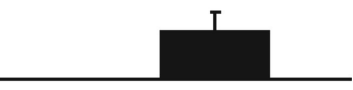

VW

Figure 2 Phosphatidylserine exposure of activated, collagen-adherent single platelets from control subjects and Scott patients. Fura-2-loaded platelets were allowed to adhere to collagen fibers in the presence of $\mathrm{Fl}$-annexin $\mathrm{V}$ and $\mathrm{CaCl}_{2}$, as described for Figure 1. Results given are percentages of annexin $\mathrm{V}$-positive platelets which exhibit an increased Fura-2 fluorescence ratio, i.e. elevated $\left[\mathrm{Ca}^{2+}\right]_{i}$. Values are means \pm SD from at least three independent incubations. (A) Experiments were performed in 1996 with platelets from control 1 and patient M.S. (B) Experiments with platelets from control 2 and patient V.W. were carried out in 2002. 


\section{Calcium responses of activated B-lymphoblasts}

Immortalized B-cells from patient M.S. and control subject 1 and from patient V.W. and control subject 2 were compared simultaneously. To analyze the $\mathrm{Ca}^{2+}$ responses of these four lymphoblast cell lines, the cells were loaded with the fluorescent probe Fluo-3 and then stimulated with agonists, reported to cause reduced SMCE in Blymphoblasts derived from the French Scott patient ${ }^{22}$. Activation was carried out in the presence of EGTA to measure $\mathrm{Ca}^{2+}$ mobilization from intracellular stores only, and in the presence of $\mathrm{CaCl}_{2}$ to allow complementary SMCE. Agonist-evoked changes in Fluo-3 fluorescence were measured in single cells by flow cytometry, using a gating profile so that only fluorescence from non-apoptotic, viable cells was analyzed. Treatment of lymphoblasts from patients and control subjects with a high dose of ionomycin (10 $\mu \mathrm{M})$ in the presence of EGTA caused the same increase in Fluo-3 fluorescence, indicative for a similar, maximal degree of $\mathrm{Ca}^{2+}$ store depletion (Table 2). Activation with the sarco/endoplasmic reticulum $\mathrm{Ca}^{2+}$-ATPase (SERCA) inhibitor thapsigargin $(1 \mu \mathrm{M})$ in the presence of EGTA to deplete SERCA-related store compartments, induced similar $\left[\mathrm{Ca}^{2+}\right]$ rises in control and patient cell lines, but the levels were slightly lower than obtained with ionomycin (Table 2). Addition of caffeine $(10 \mathrm{mM})$ in the presence of EGTA, which causes depletion of the ryanodine-sensitive $\mathrm{Ca}^{2+}$ stores (in which $\mathrm{Ca}^{2+}$ is released through ryanodine- rather than inositol-trisphosphate-activated receptors) ${ }^{22}$, had an effect on all cell lines comparable to that of thapsigargin. Together, these data indicate that the $\mathrm{Ca}^{2+}$ release from the intracellular store compartments is similar for the various control and patient B-cell lines.

Fluo-3 fluorescence (fold increase)

\begin{tabular}{lllll}
\cline { 2 - 5 } Condition & Control 1 & Control 2 & Patient M.S. & Patient V.W. \\
\hline Unstimulated & 1.00 & 1.00 & 1.00 & 1.00 \\
lonomycin, EGTA & $1.4 \pm 0.2$ & $1.5 \pm 0.1$ & $1.3 \pm 0.1$ & $1.4 \pm 0.2$ \\
Thapsigargin, EGTA & $1.3 \pm 0.2$ & $1.2 \pm 0.1$ & $1.2 \pm 0.1$ & $1.4 \pm 0.1$ \\
Caffeine, EGTA & $1.4 \pm 0.1$ & $1.3 \pm 0.2$ & $1.3 \pm 0.1$ & $1.5 \pm 0.3$ \\
lonomycin, $\mathrm{CaCl}_{2}$ & $7.5 \pm 1.4$ & $6.6 \pm 0.6$ & $6.6 \pm 1.1$ & $6.3 \pm 2.2$ \\
Thapsigargin, $\mathrm{CaCl}_{2}$ & $4.8 \pm 0.8$ & $5.0 \pm 0.8$ & $4.9 \pm 0.7$ & $4.2 \pm 1.6$ \\
Caffeine, $\mathrm{CaCl}_{2}$ & $2.9 \pm 1.1$ & $3.1 \pm 1.2$ & $2.3 \pm 0.9$ & $3.9 \pm 1.1$
\end{tabular}

Table 2 Total $\mathrm{Ca}^{2+}$ responses and $\mathrm{Ca}^{2+}$ mobilization in activated EVB-B lymphoblasts from two controls and two Scott patients. Flow cytometric results are expressed as fold increase in fluorescence intensity (arbitrary units) relative to the control (1.00). Under unstimulated conditions, averaged fluorescence intensities of the populations of Fluo-3-loaded cells were similar for all four cell lines. Values shown are means \pm SD from at least four independent experiments. 
To allow capacitative $\mathrm{Ca}^{2+}$ entry, the Fluo-3-loaded B-lymphoblasts were activated using the same agonists with extracellular $\mathrm{CaCl}_{2}$ present. Ionomycin/ $\mathrm{CaCl}_{2}$ caused a high increase in $\left[\mathrm{Ca}^{2+}\right]_{\mathrm{i}}$, which was similar for the control and patient $\mathrm{B}$ lymphoblasts (Table 2). Thapsigargin/ $\mathrm{CaCl}_{2}$ resulted in a smaller increase in $\left[\mathrm{Ca}^{2+}\right]_{i}$ due to SMCE. This response was somewhat lower in the V.W. cells in comparison to the control, but the difference was not statistically significant (Table 2). When capacitative $\mathrm{Ca}^{2+}$ entry was induced with caffeine/ $\mathrm{CaCl}_{2}$, the $\mathrm{Ca}^{2+}$ responses were lower than with thapsigargin $/ \mathrm{CaCl}_{2}$, but no differences in responsiveness were observed between the various cell lines. Combined treatment with thapsigargin/caffeine/ $\mathrm{CaCl}_{2}$ did not further increase the thapsigargin-induced $\mathrm{Ca}^{2+}$ response (fold fluorescence increase: $4.6 \pm 0.2$ for control 1, $4.7 \pm 0.4$ for M.S. (mean $\pm S D, n=3$ )), indicating efficient coupling of the thapsigargin-sensitive stores to the SMCE $\mathrm{Ca}^{2+}$ influx channels. These results typically differ from those obtained with EBV-transfected B-cells from the French Scott patient, in which case both $\mathrm{Ca}^{2+}$-ionophore $/ \mathrm{CaCl}_{2}$ and thapsigargin $/ \mathrm{CaCl}_{2}$ induced substantially lower $\mathrm{Ca}^{2+}$ responses ${ }^{22}$. Thus, the present observations show that $\mathrm{Ca}^{2+}$ release from intracellular stores and $\mathrm{Ca}^{2+}$ entry are not significantly altered in viable, non-apoptotic Blymphoblasts cells from these two different Scott patients.

\section{Relation between calcium responses and phosphatidylserine exposure in $B$ - lymphoblasts from patients}

To address the question whether the B-lymphoblasts from the patients have retained the Scott-type characteristics, we used a double-labelling procedure to directly compare $\mathrm{Ca}^{2+}$ responses (Fluo-3 loading) and PS exposure (AF-annexin $\mathrm{V}$ addition) by flow cytometric analysis. Knowing that apoptosis of B-lymphoblasts, even from Scott patients, is accompanied by PS exposure ${ }^{27}$, all analysis were performed exclusively on

$\%$ AF-annexin $\mathrm{V}$ binding cells

\begin{tabular}{lllll}
\cline { 2 - 5 } Condition & Control 1 & Control 2 & Patient M.S. & Patient V.W. \\
\hline Unstimulated & $4.0 \pm 1.8$ & $2.0 \pm 0.5$ & $1.0 \pm 0.1^{*}$ & $3.0 \pm 2.0$ \\
lonomycin, $\mathrm{CaCl}_{2}$ & $90.0 \pm 2.7$ & $85.0 \pm 18.0$ & $6.0 \pm 1.4^{*}$ & $11.0 \pm 2.1^{*}$ \\
Thapsigargin, $\mathrm{CaCl}_{2}$ & $5.0 \pm 2.5$ & $5.0 \pm 2.9$ & $2.0 \pm 0.7$ & $4.0 \pm 1.9$ \\
Caffeine, $\mathrm{CaCl}_{2}$ & $3.0 \pm 0.1$ & $2.0 \pm 1.4$ & $1.0 \pm 0.1$ & $1.0 \pm 1.3$
\end{tabular}

Table 3 Phosphatidylserine exposure in non-apoptotic Fluo-3-loaded B-lymphoblasts from two controls and two Scott patients. Data represent percentages of AF-annexin $\mathrm{V}$ positive cells (means $\pm \mathrm{SD}, \mathrm{n}=4-6$ ). ${ }^{*} P<0.05$ compared to value of corresponding control cells. 
the non-apoptotic cell population. In the absence of stimulation, both the control B-cells and the cells derived from patients M.S. and V.W. exhibited comparably low PS exposure (Table 3). When treated with ionomycin $(10 \mu \mathrm{M})$ in the presence of $\mathrm{CaCl}_{2}$, 85$90 \%$ of the B-lymphoblasts from the controls became PS-positive, versus only $6 \%$ and $11 \%$ of the B-lymphoblasts of patient M.S. and V.W., respectively.

When SMCE was induced by $\mathrm{CaCl}_{2}$ after emptying the $\mathrm{Ca}^{2+}$ stores with thapsigargin, no PS exposure was observed in either control or patient B-lymphoblasts (Table 3), despite the fact that the thapsigargin-induced $\mathrm{Ca}^{2+}$ responses were high (see Table 2). Similarly, addition of caffeine - either alone or in combination with thapsigargin - did not lead to significant PS exposure in viable cells for any of the cell lines.

Further analysis of the double label flow-cytometric data clearly indicate that the $\mathrm{Ca}^{2+}$ signals caused by thapsigargin/CaCl 2 were lower but in the same range as those evoked by ionomycin $/ \mathrm{CaCl}_{2}$, whereas only the latter agonist was capable to induce PS exposure in control B-lymphoblasts (Figure 3). Thus, in the control cells, ionomycin appears to be a much better stimulus for PS exposure than thapsigargin or caffeine,

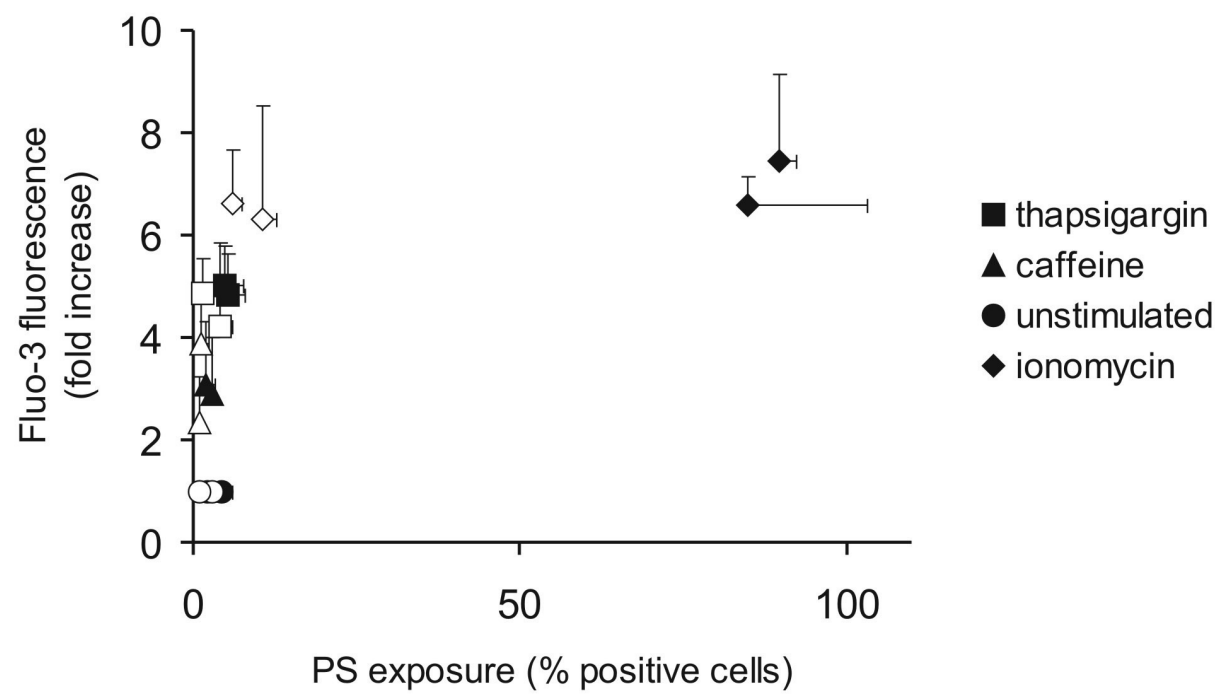

Figure 1 Collagen-induced $\mathrm{Ca}^{2+}$ responses of single platelets from control subjects and Scott patients. Fura-2-loaded platelets were allowed to adhere to collagen fibers in the presence of $\mathrm{CaCl}_{2}(2$ $\mathrm{mM}$ ). Changes in Fura-2 fluorescence ratio in single platelets were measured by fluorescence video imaging microscopy. (A) Experiments were performed in 1996 with platelets from control 1 and patient M.S. (B) Experiments with platelets from control 2 and patient V.W. were carried out in 2002. Changes in Fura-2 fluorescence ratio (340/380 nm excitation) were recorded during adhesion and activation, as described in Materials and Methods. Traces are averaged overlays of single traces obtained from at least twenty platelets per subject ( $n \geq 3$ incubations/subject). 
despite the fact that the latter agents cause substantial $\mathrm{Ca}^{2+}$ influx, suggesting a particular action of ionomycin/ $/ \mathrm{Ca}^{2+}$ on the phospholipid scrambling process.

\section{Discussion}

The transmembrane phospholipid asymmetry, characteristic of the plasma membrane of most mammalian cells, is maintained by two distinct plasma membrane proteins: the aminophospholipid translocase, which causes a rapid inward transport of aminophospholipids, and -as demonstrated for erythrocytes- the multidrug resistance protein MRP1, which facilitates a slow outward movement of membrane phospholipids, irrespective the composition of the polar headgroup. These proteins assure that procoagulant anionic phospholipids, such as PS, remain localized in the cytoplasmic leaflet of the plasma membrane (reviewed $\mathrm{n}^{30}$ ). A third protein is responsible for a rapid bidirectional transbilayer movement of the phospholipids in the plasma membrane. Activation of this protein causes a collaps of the asymmetric lipid distribution in the plasma membrane; hence this protein has been termed 'phospholipid scramblase',30. Activation of the scramblase causes exposure of PS at the cell surface, which serves an important function in the process of blood coagulation. Patients with an impaired scramblase activity suffer from a bleeding disorder, referred to as Scott syndrome, illustrating the importance of this membrane remodelling process. Scrambling activity has been demonstrated in most haematological cells; Sims and coworkers have cloned a protein from erythrocytes with Ca-dependent scrambling activity, a protein which is now referred to as human phospholipid scramblase (hPLSCR1, reviewed $\mathrm{in}^{31}$ ). However, there is increasing doubt about the true function of this protein. As was found recently, adult PLSCR1(-/-) mice showed no obvious haematologic or haemostatic abnormality, and blood cells from these animals normally mobilized phosphatidylserine to the cell surface upon stimulation ${ }^{32}$. Thus, the identity of the scramblase remains to be elucidated. The finding that the phenotype of defective PS exposure in the Scott syndrome affects all cells of the haematological lineage as well as the hereditary transmission of this disorder strongly suggest the involvement of a protein in the scrambling process. Although it has been demonstrated that lipid scrambling does not require hydrolysis of ATP and that activity of the scramblase requires a persistent elevation of intracellular $\mathrm{Ca}^{2+}$, the mode of action and the regulation of the scramblase remain to be elucidated.

In the present study, we introduce a new case with characteristics of the Scott syndrome. Patient V.W. has been described in an early study published in 1980 as the propositus of a family with a platelet-related bleeding disorder despite a normal 
coagulation profile ${ }^{5}$, but has not been recognised as having Scott syndrome. The data obtained in this study clearly demonstrate an impaired $\mathrm{Ca}^{2+}$-induced PS exposure in the patient's erythrocytes, platelets and lymphoblasts as judged from decreased prothrombinase activities and annexin $\mathrm{V}$ binding, confirming the Scott phenotype. Note that for patient V.W. the procoagulant response of platelets treated with ionophore seems to be more impaired than that of platelets activated with collagen plus thrombin. This has been a consistent finding over several years with the platelets of patient M.S. In both the French propositus with Scott syndrome and the canine model of Scott syndrome, platelet prothrombinase activity was virtually absent, independent of whether the cells were activated with ionophore or with collagen plus thrombin ${ }^{6,9}$. The reason for this difference in phenotype is as yet unclear. Whether the partially impaired procoagulant response after collagen plus thrombin stimulation of platelets of patients V.W. and M.S. illustrates different pathways of activation or the existence of more than one mechanism for phospholipid scrambling in platelets remains to be investigated. In this respect, it is of interest to mention that the defect in ionomycin-induced PS exposure in the EBV-transformed B cells of the two patients is not observed for the apoptotic cells from these patients (data not shown), in agreement with the suggestion that phospholipid scrambling in apoptotic cells is differently regulated from the scrambling caused by $\mathrm{Ca}^{2+}$ elevating agents ${ }^{27}$ ).

SMCE following $\mathrm{Ca}^{2+}$ mobilization from intracellular stores presents the most important $\mathrm{Ca}^{2+}$ entry pathway in platelets and lymphocytes. Recently, Martinez and coworkers have described that B-lymphoblasts from a French Scott patient exhibit normal $\mathrm{Ca}^{2+}$ release from the thapsigargin- and caffeine-depletable $\mathrm{Ca}^{2+}$ stores, but show a considerably reduced subsequent $\mathrm{Ca}^{2+}$ entry, along with a reduced PS exposure ${ }^{4,22}$. Interestingly, $\mathrm{Ca}^{2+}$ entry following depletion of both the thapsigargin and caffeinesensitive stores became normalized in these B-lymphoblasts. In the present study, we also measured thapsigargin- and caffeine-mediated release of $\mathrm{Ca}^{2+}$ from stores as well as subsequent $\mathrm{Ca}^{2+}$ entry. In agreement with their observations, we found no indications for disturbances in the release from stores. However, in contrast to the French Scott Blymphoblasts, the B-cells from both patients M.S. and V.W. appeared to have normal $\mathrm{Ca}^{2+}$ influx via SMCE with thapsigargin or caffeine as well as $\mathrm{Ca}^{2+}$ ionophore. Furthermore, the combination of thapsigargin and caffeine did not further increase the $\mathrm{Ca}^{2+}$ signal or the PS exposure. The reason for this discrepancy is not known, but may reflect a variant of the Scott syndrome.

The finding that $\mathrm{Ca}^{2+}$ responses in both the platelets and B-cells from patients M.S. and V.W. are unaltered indicates that aberrant $\mathrm{Ca}^{2+}$ signaling -at least in these two 
patients- is not part of the Scott phenotype. The double-labelling techniques applied with both platelets and non-apoptotic B-cells show that Scott cells of either type are greatly diminished in PS exposure although being high in $\left[\mathrm{Ca}^{2+}\right]_{\text {. }}$. Even for the control B-cells, there is no simple relationship between elevated $\left[\mathrm{Ca}^{2+}\right]_{i}$ and PS exposure (Figure 3 ), suggesting that the scrambling process is not dependent on high $\left[\mathrm{Ca}^{2+}\right]_{i}$ only, but relies on other intracellular processes as well, in agreement with previous findings ${ }^{16}$. This suggestion is supported by recent evidence that also in stimulated human T-lymphocytes the phospholipid scrambling with $\mathrm{Ca}^{2+}$ ionophore is mediated by factors other than elevated $\left[\mathrm{Ca}^{2+}\right]_{i}$ only ${ }^{33}$.

In summary, the present study shows that patient V.W. can be considered as having a Scott syndrome phenotype. The impaired lipid scrambling in platelets and B-cells from both Scott patients presented here, cannot be ascribed to alterations in $\mathrm{Ca}^{2+}$ release from intracellular stores or subsequent $\mathrm{Ca}^{2+}$ entry.

\section{Acknowledgement}

We thank Professor E.G.D. Tuddenham and his colleagues for making available the EBV-transformed B-cells from patient V.W. Professor H.J. Weiss is acknowledged for making available blood samples from patient M.S. for the part of the study that was carried out in 1996.

\section{References}

1. Weiss HJ, Vicic WJ, Lages BA, Rogers J. Isolated deficiency of platelet procoagulant activity. Am J Med. 1979;67:206-213.

2. Bevers EM, Wiedmer T, Comfurius P, Shattil SJ, Weiss HJ, R.F.A. Z, Sims PJ. Defective $\mathrm{Ca}^{2+}$-induced microvesiculation and deficient expression of procoagulant activity in erythrocytes from a patient with a bleeding disorder. A study of the red blood cells of Scott syndrome. Blood. 1992;79:380-388.

3. Kojima H, Newtonnash D, Weiss HJ, Zhao J, Sims PJ, Wiedmer T. Production and characterization of transformed B-lymphocytes expressing the membrane defect of Scott syndrome. J Clin Invest. 1994;94:2237-2244.

4. Martin S, Laude-Lemaire I, Kerbiriou-Nabias D, Freyssinet JM, Martinez MC. Relation between phosphatidylserine exposure and store-operated $\mathrm{Ca}^{2+}$ entry in stimulated cells. Biochem Biophys Res Commun. 2000;279:639-645.

5. Parry $\mathrm{DH}$, Giddings JC, Bloom AL. Familial haemostatic defect associated with reduced prothrombin consumption. Br J Haematol. 1980;44:323-334.

6. Toti F, Satta N, Fressinaud E, Meyer D, Freyssinet JM. Scott syndrome, characterized by impaired transmembrane migration of procoagulant phosphatidylserine and hemorrhagic complications, is an inherited disorder. Blood. 1996;87:1409-1415.

7. Dachary-Prigent J, Pasquet JM, Fressinaud E, Toti F, Freyssinet JM. Aminophospholipid exposure, microvesiculation and abnormal protein tyrosine phosphorylation in the platelets of 
a patient with Scott syndrome: a study using physiologic agonists and local anaesthetics. $\mathrm{Br} \mathrm{J}$ Haematol. 1997;99:959-967.

8. Bettache N, Gaffet P, Allegre N, Maurin L, Toti F, Freyssinet JM, Bienvenue A. Impaired redistribution of phospholipids with distinctive cell shape change during $\mathrm{Ca}^{2+}$-induced activation of platelets from a patient with Scott syndrome. Br J Haematol. 1998;101:50-58.

9. Brooks MB, Catalfamo JL, Brown HA, Ivanova P, Lovaglio J. A hereditary bleeding disorder of dogs caused by a lack of platelet procoagulant activity. Blood. 2002;99:2434-2441.

10. Berridge MJ. Inositol trisphosphate and calcium signaling. Nature. 1993;361:315-325.

11. Siess W. Molecular mechanisms of platelet activation. Physiol Rev. 1989;69:58-178.

12. Heemskerk JWM. Calcium and platelets. In: The Molecular Basis of Calcium Action in Biology and Medicine (Pochet, R, Donato, R, Haiech, J, Heinzmann, C and Gerke, V, eds), Kluwer Acad Publ, The Hague (the Netherlands). 2000:45-71.

13. Williamson P, Bevers EM, Smeets EF, Comfurius P, Schlegel RA, Zwaal RFA. Continuous analysis of the mechanism of activated transbilayer lipid movement in platelets. Biochemistry. 1995;34:10448-10455.

14. Siljander P, Farndale RW, Feijge MAH, Comfurius P, Kos S, Bevers EM, Heemskerk JWM. Platelet adhesion enhances the glycoprotein VI-dependent procoagulant response: involvement of p38 MAP kinase and calpain. Arterioscler Thromb Vasc Biol. 2001;21:618-627.

15. Heemskerk JWM, Vuist WMJ, Feijge MAH, Reutelingsperger CPM, Lindhout T. Collagen but not fibrinogen surfaces induce bleb formation, exposure of phosphatidylserine and procoagulant activity of adherent platelets. Evidence for regulation by protein tyrosine kinasedependent $\mathrm{Ca}^{2+}$ responses. Blood. 1997;90:2615-2625.

16. Smeets EF, Heemskerk JWM, Comfurius P, Bevers EM, Zwaal RFA. Thapsigargin amplifies the platelet procoagulant response caused by thrombin. Thromb Haemost. 1993;70:1024-1029.

17. Heemskerk JWM, Feijge MAH, Henneman L, Rosing J, Hemker HC. The $\mathrm{Ca}^{2+}$-mobilizing potency of $\alpha$-thrombin and thrombin-receptor-activating peptide on human platelets. Concentration and time effects of thrombin-induced $\mathrm{Ca}^{2+}$ signaling. Eur $\mathrm{J}$ Biochem. 1997;249:547-555.

18. Den Dekker E, Molin DGM, Breikers G, van Oerle R, Akkerman JWN, van Eys GJJM, Heemskerk JWM. Expression of transient receptor potential mRNA isoforms and $\mathrm{Ca}^{2+}$ influx in differentiating human stem cells and platelets. Biochim Biophys Acta. 2001;1539:243-255.

19. Heemskerk JWM, Siljander P, Vuist WMJ, Breikers G, Reutelingsperger CPM, Barnes MJ, Knight CG, Lassila R, Farndale RW. Function of glycoprotein VI and integrin $\alpha_{2} \beta_{1}$ in the procoagulant response of single, collagen-adherent platelets. Thromb Haemost. 1999;81:782-792.

20. Shcherbina A, Rosen FS, Remold-O' Donnell E. Pathological events in platelets of WiskottAldrich syndrome patients. Br J Haematol. 1999;106:875-883.

21. Pasquet JM, Quek L, Stevens C, Bobe R, Huber M, Duronio V, Krystal G, Watson SP. Phosphatidylinositol 3,4,5-trisphosphate regulates $\mathrm{Ca}^{2+}$ entry via Btk in platelets and megakaryocytes without increasing phospholipase C activity. EMBO J. 2000;19:2793-2802.

22. Martinez MC, Martin S, Toti F, Fressinaud E, Dachary-Prigent J, Meyer D, Freyssinet JM. The significance of capacitative $\mathrm{Ca}^{2+}$ entry in the regulation of phosphatidylserine expression at the surface of stimulated cells. Biochemistry. 1999;38:10092-10098.

23. Rosing J, Bevers EM, Comfurius P, Hemker HC, van Dieijen G, Weiss HJ, Zwaal RFA. Impaired factor $X$ - and prothrombin activation associated with decreased phospholipid exposure in platelets from a patient with a bleeding disorder. Blood. 1985;65:1557-1561.

24. Weiss HJ. Scott syndrome: a disorder of platelet coagulant activity. Sem Hematol. 1994;31:312-319.

25. Feijge MAH, van Pampus ECM, Lacabaratz-Porret C, Hamulyak K, Lévy-Toledano S, Enouf $\mathrm{J}$, Heemskerk JWM. Inter-individual varability in $\mathrm{Ca}^{2+}$ signaling in platelets from healthy volunteers, relation with expression of endomembrane $\mathrm{Ca}^{2+}$-ATPases. $\mathrm{Br} \mathrm{J}$ Haematol. 1998; 102:850-859. 
26. Rosing J, Rijn van JL, Bevers EM, van Dieijen G, Comfurius P, Zwaal RFA. The role of activated human platelets in prothrombin and factor $X$ activation. Blood. 1985;65:319-332.

27. Williamson P, Christie A, Kohlin T, Schlegel RA, Comfurius P, Harmsma M, Zwaal RFA, Bevers EM. Phospholipid scramblase activation pathways in lymphocytes. Biochemistry. 2001;40:8065-8072.

28. Andree HAM, Stuart MCA, Hermens WT, Reutelingsperger CPM, Hemker HC, Frederik PM, Willems GM. Clustering of lipid-bound annexin $\mathrm{V}$ may explain its anticoagulant effect. J Biol Chem. 1992;267:17907-17912.

29. Thiagarajan P, Tait JF. Collagen-induced exposure of anionic phospholipids in platelets and platelet-derived microparticles. J Biol Chem. 1991;266:24302-24307.

30. Bevers EM, Comfurius P, Dekkers DW, Zwaal RF. Lipid translocation across the plasma membrane of mammalian cells. Biochim Biophys Acta. 1999;1439:317-330.

31. Sims PJ, Wiedmer T. Unraveling the mysteries of phospholipid scrambling. Thromb Haemost. 2001;86:266-275.

32. Zhou Q, Zhao J, Wiedmer T, Sims PJ. Normal hemostasis but defective hematopoietic response to growth factors in mice deficient in phospholipid scramblase 1. Blood. 2002;99:4030-4038.

33. Wurth GA, Zweifach A. Evidence that cytosolic calcium increases are not sufficient to stimulate phospholipid scrambling in human T-lymphocytes. Biochem J. 2002;362:701-708. 



\section{Chapter 3}

\section{Specific roles of PI3K isoforms $\alpha$ and $\beta$ in glycoprotein VI-induced platelet signaling to procoagulant activity}

Imke C. A. Munnix, Judith M. E. M. Cosemans, Marion A. H. Feijge, Paola E. J. van der Meijden, Aafke P. A. van Montfoort, Richard W. Farndale, Shigeo Koyasu, Regine Heller, Stewart S. O. Sage, Shaun P. Jackson and Johan W. M. Heemskerk 


\section{Abstract}

Platelets contain various forms of phosphoinositide 3-kinase (PI3K), which contribute to platelet activation in a non-clarified way. Here, we investigated the roles of platelet $\mathrm{PI} 3 \mathrm{~K}$ isoforms in glycoprotein $\mathrm{VI}$ (GPVI)-induced $\mathrm{Ca}^{2+}$ signaling and procoagulant activity during thrombus formation. We used mouse platelets deficient in the $\mathrm{p} 85 \alpha$ regulatory $\mathrm{PI} 3 \mathrm{~K}$ subunit or the $\mathrm{p} 110 \%$ catalytic subunit, as well as high-affinity PI3K inhibitors, specifically blocking the $\mathrm{p} 110 \alpha, \beta, \gamma$ or $\delta$ catalytic subunits. Under highshear flow conditions, absence of murine $\mathrm{p} 85 \alpha$ or inhibition of PI3K $\alpha$ or $\beta$ lowered GPVIinduced $\mathrm{Ca}^{2+}$ responses and subsequent procoagulant activity (phosphatidylserine exposure). In contrast, absence of $\mathrm{p} 110 \gamma$ only delayed the GPVI-induced $\mathrm{Ca}^{2+}$ signal and did not influence procoagulant activity. Experiments with human platelets showed that the contribution of $\mathrm{PI} 3 \mathrm{~K}$ to GPVI-induced $\mathrm{Ca}^{2+}$ signaling and procoagulant activity was independent of autocrine released ADP. Furthermore, blockage of either PI3K $\alpha$ or $\beta$ catalytic activity was sufficient to completely suppress the enhancing effect of PI3K on mobilisation of $\mathrm{Ca}^{2+}$ from internal stores. Combined inhibition of $\mathrm{PI} 3 \mathrm{~K} \alpha$ and $\beta$ was without extra effect, while inhibition of PI3K $\delta$ was only partly effective. Taken together, the present results indicate that the principle mechanism of action of PI3K on GPVI-induced $\mathrm{Ca}^{2+}$ signaling and PS exposure is enhancement of phospholipase C $\gamma 2$-mediated stimulation of $\mathrm{Ca}^{2+}$ depletion from internal stores, and subsequent store-mediated $\mathrm{Ca}^{2+}$ entry. Furthermore, particularly the $\mathrm{PI} 3 \mathrm{~K} \alpha$ and $\beta$ isoforms, acting via p $85 \alpha$, appear to be involved in this activation pathway, with $\mathrm{PKI} 3 \delta$ playing a minor role.

\section{Introduction}

Cytosolic $\left[\mathrm{Ca}^{2+}\right]_{i}$ elevation is a key regulating signal for most platelet activation processes, such as shape change, release of autocoid mediators, aggregation and, particularly, development of procoagulant activity ${ }^{1,2}$. The signal transduction processes to the procoagulant platelet response are not well investigated, although it is clear that these require a high, threshold $\left[\mathrm{Ca}^{2+}\right]_{i}$ elevation, which mediates scrambling of plasma membrane phospholipids, exposure of the phosphatidylserine (PS) at the platelet surface, and shedding of microparticles ${ }^{3}$. The PS-exposing platelets and microparticles avidly assemble coagulation factors, and thus mediate massive formation of factor $\mathrm{Xa}$ and thrombin during the propagation phase of the coagulation process ${ }^{4}$.

In both human and mouse platelets, the $G_{q}$ protein-coupled receptor agonists thrombin, ADP and thromboxane $A_{2}$ activate phospholipase $C$ (PLC) $\beta$ and form inositol 
1,4,5-trisphosphate $\left(\mathrm{IP}_{3}\right)^{5,6}$. By themselves, these agonists are unable to trigger the platelet procoagulant response, likely because of the relative short duration of the $\mathrm{Ca}^{2+}$ signal. In contrast, platelet stimulation of the immunoglobulin family receptor, glycoprotein VI (GPVI) - using agonists as collagen, collagen peptide and convulxin results in a more prolonged elevation in $\left[\mathrm{Ca}^{2+}\right]_{\mathrm{i}}^{4,7,8}$. The GPVI receptor signals via Src and Syk tyrosine kinases to activate PLC $\gamma 2$ in a pathway that is supported by several other protein kinases, particularly of the Btk/Tec and phosphoinositide 3-kinase (PI3K) families $^{9,10}$.

In lymphocytes and mast cells, triggering of immunoglobulin receptors also leads to activation of PLC $\gamma$ isoforms, in a way promoted by PI3K activation ${ }^{11,12}$. In these cells, plasma membrane accumulation of the PI3K product, phosphatidylinositol 3,4,5trisphosphate $\left(\mathrm{PIP}_{3}\right)$, is assumed to function as an anchoring site of the activated PLC $\gamma$ via its $N$-terminal pleckstrin homology $(\mathrm{PH})$ domain. Accordingly, the $\mathrm{PIP}_{3}$ ensures sustained formation of $\mathrm{IP}_{3}$ and $\mathrm{Ca}^{2+}$ signals ${ }^{13}$.

Human and murine platelets contain various PI3K isoforms, which are distinguished according to their catalytic subunits. These are the class IA isoforms $\mathrm{PI} 3 \mathrm{~K} \alpha, \beta$ and $\delta(\mathrm{p} 110 \alpha, \mathrm{p} 110 \beta$ and $\mathrm{p} 110 \delta)$, and the class IB isoform PI3K $\gamma(\mathrm{p} 110 \gamma)^{14-16}$. Platelets further contain the class IA PI3K regulatory subunits, $p 85 \alpha, p 85 \beta$ and $p 55 \gamma$, and a unique class IB regulatory subunit, $\mathrm{p} 101 \gamma$.

In general, the class IA isoforms bind to $\mathrm{SH} 2$ domain-containing regulatory subunits, particularly $\mathrm{p} 85 \alpha$ and, therefore, are considered to be regulated by tyrosine kinases. In contrast, class IB isoforms are supposed to be activated by G-protein coupled receptors ${ }^{15}$. Whether this is also the case for platelets, has not yet been investigated. It is also not completely sure which regulatory subunit can bind to which catalytic subunit. As far as known, the inter-SH2 domains of p $85 \alpha, p 55 \alpha, p 50 \alpha, p 85 \beta$ and $p 55 \gamma$ constitutively interact with the $\mathrm{N}$-terminal domain of $\mathrm{p} 110 \alpha, \beta$ and $\delta$. Binding of the dual SH2 domains to tyrosine-phosphorylated adaptor proteins activates the kinase function of the p110 subunits. However, for platelets only little is known of the contribution of the individual PI3K isoforms in signal transduction. In mouse and human platelets, PI3K p85 $\alpha$ was found to play a role in GPVI/FcR $\gamma$-chain signaling ${ }^{8,17,18}$. This corroborates with the finding that $\mathrm{PI} 3 \mathrm{~K}$ inhibition reduces the $\mathrm{Ca}^{2+}$ signal evoked by collagen peptides ${ }^{8}$, although the mechanism of this is still unclear. Furthermore, both $\mathrm{PI} 3 \mathrm{~K} \beta$ and $\mathrm{PI} 3 \mathrm{~K} \gamma$ have been implicated in ADP-induced platelet aggregation and aggregate stabilization ${ }^{16,19,20}$, which deviates from the paradigm of class $1 \mathrm{~A}$ and $1 \mathrm{~B}$ isoforms being triggered by distinct signaling processes. To date, the role of individual 
PI3K catalytic isoform activities in regulating GPVI-induced $\mathrm{Ca}^{2+}$ signaling and procoagulant activity is still unknown.

There are several pieces of evidence that platelet PI3K contributes to $\mathrm{Ca}^{2+}$ signaling in response to collagen peptides in yet another way. The $\mathrm{PI} 3 \mathrm{~K}$ product $\mathrm{PIP}_{3}$ was found to mediate activation of $\mathrm{Ca}^{2+}$ entry either directly by influencing the $\mathrm{Ca}^{2+}$ channels themselves ${ }^{21}$, or via the Tec-family protein kinase, Btk, independently of PLC $\gamma^{22}$. This $\mathrm{Ca}^{2+}$ influx pathway was suggested to be responsible for collagen-evoked PS exposure ${ }^{22}$. However, the mechanism of inhibition has not further been studied.

In this paper, we studied the contribution of PI3K in GPVI-induced platelet $\mathrm{Ca}^{2+}$ responses, using mice deficient in distinct PI3K subunits, $\mathrm{p} 85 \alpha$ or $\mathrm{p} 110 \gamma$, and using a panel of isoform-specific PI3K inhibitors in combination with human platelets. Hereby, we focussed on monitoring of $\mathrm{Ca}^{2+}$ signaling and PS exposure under physiologically relevant flow conditions.

\section{Materials and methods}

\section{Animals}

Animal experiments were approved by the local animal experimental committees. Mice deficient in the $\mathrm{p} 85 \alpha$ regulatory $\mathrm{PI} 3 \mathrm{~K}$ subunit on $\mathrm{C} 57 \mathrm{BL} / 6$ genetic background were generated, as described ${ }^{23}$. Mice deficient in the $\mathrm{p} 110 \gamma$ catalytic subunit (PI3K $\gamma$ ) were bred on a $129 \mathrm{~Sv}$ background as described ${ }^{24}$. Wildtype mice of the same genetic background and same breeding programs were used as control animals.

\section{Materials}

Fibrillar type-1 collagen (Horm) from equine tendon was purchased from Nycomed. Collagen-related peptide (CRP), containing triple-helical polymers of Gly-ProHyp, was prepared and cross-linked, as described before ${ }^{25}$. The GPVI agonist, convulxin $^{26}$, was purified to homogeneity from the venom of Crotalus durissus terrificus (Latoxan), as described ${ }^{27}$. Fura-2 and Fluo-3 acetoxymethyl esters and Pluronic F-127 were purchased from Molecular Probes. Oregon green 488-labelled annexin A5 (OG488annexin A5) was from Nexins Research. Bovine serum albumin (BSA), apyrase (grade $\mathrm{V})$, aspirin, thrombin, wortmannin and MRS2179, a $\mathrm{P}_{2} \mathrm{Y}_{1}$ antagonist, were from Sigma. LY294002 and H-Phe-Pro-Arg chloromethyl ketone (PPACK) were from Calbiochem. Isoform-selective PI3K inhibitors were a kind gift from the Baker Heart Research 
Institute, and synthesized as described ${ }^{16,28}$. These were (with cell-free $I_{50}$ concentrations): PI103 and YM024, selective for $\mathrm{p} 110 \alpha(0.008$ and $0.3 \mu \mathrm{M}$, respectively); TGX221, selective for the $p 110 \beta$ isoform $(0.05 \mu \mathrm{M})$; AS252424, selective for $\mathrm{p} 110 \gamma(0.035 \mu \mathrm{M})$; and IC87114, selective for $\mathrm{p} 110 \delta(0.5 \mu \mathrm{M})$. Cangrelor (ARC69931MX), an antagonist of the $\mathrm{P}_{2} \mathrm{Y}_{12}$ receptor, was kindly provided by The Medicines Company. Acetylsalicylic acid (aspirin) was purchased from Lorex Synthelabo. Other reagents were of analytical grade and from sources as described ${ }^{29}$.

\section{Blood collection and platelet isolation}

For flow experiments, human blood was collected into $40 \mu \mathrm{M}$ PPACK, and mouse blood was collected into $40 \mu \mathrm{M}$ PPACK and $5 \mathrm{U} / \mathrm{ml}$ heparin, as described previously ${ }^{29,30}$. For measurements of cytosolic $\left[\mathrm{Ca}^{2+}\right]$, human or mouse blood was collected on one-sixth volume of acid-citrate-dextrose anticoagulant, composed of 85 $\mathrm{mM}$ sodium citrate, $78 \mathrm{mM}$ citric acid and $11 \mathrm{mM}$ D-glucose. Platelet-rich plasma and washed platelets were obtained by centrifugation, as described before for human ${ }^{30}$ and mouse ${ }^{29}$ platelets. Mouse platelets were finally resuspended in Hepes buffer I (5 mM Hepes, $136 \mathrm{mM} \mathrm{NaCl}, 2.7 \mathrm{mM} \mathrm{KCl}, 0.42 \mathrm{mM} \mathrm{NaH}_{2} \mathrm{PO}_{4}, 2 \mathrm{mM} \mathrm{MgCl}_{2}, 0.1 \%$ glucose and $0.1 \% \mathrm{BSA}, \mathrm{pH} 7.45)$. Cells were counted with a Coulter counter.

\section{Measurement of thrombus formation and procoagulant response under flow}

Whole blood perfusion experiments were performed, as described previously for human $^{30}$ and mouse ${ }^{29}$ blood. Briefly, coverslips were coated with collagen fibres (12.5 $\mu \mathrm{g} / \mathrm{cm}^{2}$ ) and blocked with Hepes buffer at $\mathrm{pH} 7.45$ containing $1 \%$ BSA. Blood anticoagulated with PPACK was perfused over the coverslip through a transparent 50$\mu \mathrm{m}$ deep flow chamber by using a 1-ml syringe and a pulse-free pump, at a shear rate of $1000 \mathrm{~s}^{-1}$ for $4 \mathrm{~min}$. The blood was incubated for $10 \mathrm{~min}$ prior to perfusion with various inhibitors, as indicated. During and after perfusion, microscopic phase-contrast and fluorescence images were recorded in real-time using a Visitech imaging system, equipped with two intensified CCD cameras. After 4 min of perfusion, flow chambers were rinsed with Hepes buffer I, supplemented with $1 \mathrm{U} / \mathrm{ml}$ heparin and $2 \mathrm{mM} \mathrm{CaCl}_{2}$ at the same shear rate for 4 min. Exposure of PS was detected with OG488-annexin A5 (1 $\mu \mathrm{g} / \mathrm{ml}$ ) in $\mathrm{CaCl}_{2}$ Hepes buffer I. Recorded images were analysed on surface area coverage, as described before ${ }^{31}$. 


\section{Measurement of $\mathrm{Ca}^{2+}$ responses under flow}

Human platelet-rich plasma was incubated with $7 \mu \mathrm{M}$ Fluo-3 acetoxymethyl ester for $45 \mathrm{~min}$ at $20^{\circ} \mathrm{C}$, gentle rotating. Washed mouse platelets were incubated with 5 $\mu \mathrm{M}$ Fluo-3 acetoxymethyl ester and $0.2 \mathrm{mg} / \mathrm{ml}$ Pluronic F-127 under the same conditions. After labelling, the platelets were added back to whole blood from the same donor or mouse strain to give $10 \%$ labelled platelets. Changes in fluorescence in Fluo3-loaded, collagen-adhered platelets were obtained using the Visitech imaging system by highspeed $(5 \mathrm{~Hz})$ recording of fluorescence images, and off-line analysis of regions-ofinterest representing single platelets ${ }^{32}$. Calibration to $\left[\mathrm{Ca}^{2+}\right]_{i}$ was by pseudo-ratioing to give $F / F_{o}$ values and fixed calibration values ${ }^{33}$. For quantitative data, traces from individual cells were superimposed, so that $\left[\mathrm{Ca}^{2+}\right]_{\mathrm{i}}$ initially increased after $3.0 \mathrm{~s}$.

\section{Measurements of $\mathrm{Ca}^{2+}$ responses in platelet suspension}

Human Fura-2-loaded platelets were prepared as described previously ${ }^{34}$. ACDanticoagulated platelet-rich plasma was incubated with aspirin $(100 \mu \mathrm{M})$ and apyrase (0.2 U ADPase $/ \mathrm{ml}$ ) at $37^{\circ} \mathrm{C}$ with $2.5 \mu \mathrm{M}$ Fura-2 acetoxymethyl ester for $45 \mathrm{~min}$. Platelets were collected by centrifugation at $350 \mathrm{~g}$ for $20 \mathrm{~min}$. The cells were resuspended in Hepes buffer II, containing $145 \mathrm{mM} \mathrm{NaCl}, 10 \mathrm{mM}$ Hepes, $10 \mathrm{mM}$ D-glucose, $5 \mathrm{mM} \mathrm{KCl}, 1$ $\mathrm{mM} \mathrm{MgSO}_{4}$ and $0.1 \%$ BSA, which was supplemented with $40 \mu \mathrm{g} / \mathrm{ml}$ apyrase. Concentrations of vehicle $\mathrm{Me}_{2} \mathrm{SO}$ did not exceed 0.2 vol\%, and equivalent volumes of $\mathrm{Me}_{2} \mathrm{SO}$ vehicle were present in control samples.

Fluorescence was recorded from $1.5 \mathrm{ml}$ aliquots of magnetically stirred platelet suspension $\left(10^{8}\right.$ cells $\left./ \mathrm{ml}\right)$ at $37^{\circ} \mathrm{C}$ using a Cairn Research spectrofluorometer ${ }^{35}$ or a SLM-Aminco spectrofluorometer ${ }^{1}$, at excitation wavelengths of 340 and $380 \mathrm{~nm}$ and emission at $500 \mathrm{~nm}$. Changes in $\left[\mathrm{Ca}^{2+}\right]_{\mathrm{i}}$ were determined using the calibrated $340 / 380$ fluorescence ratio method ${ }^{36}$. When coloured antagonists were used interfering with the Fura-2 fluorescence signal, calibrations were performed in the presence of these antagonists. Time plots were constructed of agonist-evoked increases in $\left[\mathrm{Ca}^{2+}\right]_{i}$ relative to basal level (i.e. the level before addition of agonist). Mobilisation and total $\mathrm{Ca}^{2+}$ influx induced by specific agonists were measured by comparing 2.5 min-integrals of the agonist-evoked rises in $\left[\mathrm{Ca}^{2+}\right]_{i}^{37}$. Therefore, $\mathrm{Ca}^{2+}$ response curves were determined in the presence of either $1 \mathrm{mM}$ EGTA (allowing only intracellular $\mathrm{Ca}^{2+}$ mobilisation) or $1 \mathrm{mM}$ $\mathrm{CaCl}_{2}$ (allowing $\mathrm{Ca}^{2+}$ mobilisation and $\mathrm{Ca}^{2+}$ influx). 


\section{Statistics}

Differences between experimental groups were statistically tested with the nonparametric Mann-Whitney $U$ test. Effects of inhibitors were tested in paired incubations using the Student's paired $t$ test. The statistical package for social sciences was used (SPSS 11.0). Data are presented as means \pm SEM.

\section{Results}

\section{Absence of murine $p 85 \alpha$ or blocking of PI3K $\beta$ reduces GPVI-evoked PS exposure under flow}

With mice lacking the $p 85 \alpha$ regulatory PI3K subunit (which links to class IA catalytic subunits) and mice deficient in the class IB catalytic subunit $\mathrm{p} 110 \gamma$, we studied the contribution of the PI3K isoform classes to GPVI-induced platelet responses. These mice had normal levels of platelets and, furthermore, their platelets expressed normal levels of adhesive receptors (data not shown, but see Refs. ${ }^{18,24}$ ). Whole blood of these mice, anticoagulated with PPACK-heparin, was used to measure collagen-induced thrombus formation and platelet procoagulant activity under high-shear perfusion. Earlier, we have shown for murine and human blood that, under these conditions, platelet activation, thrombus build-up and procoagulant activity are strictly GPVIdependent processes ${ }^{29-31,38}$. Perfusion of wildtype blood at a high shear rate of $1000 \mathrm{~s}^{-1}$ resulted in platelet aggregate formation on collagen, while staining with OG488-labeled annexin A5 indicated that many of the collagen-bound platelets expressed PS (Figure $1 \mathrm{~A})$. With blood from $\mathrm{p} 85 \alpha-/$ - or $\mathrm{p} 110 \gamma-/$ - mice, platelet aggregates were still formed, although in case of the $\mathrm{p} 110 \gamma \mathrm{-} /$ - platelet aggregate size was relatively small, such in agreement with earlier observations that this PI3K isoform is implicated in aggregate stability $^{20}$. Typically, for $p 85 \alpha-/$ - blood, platelet deposition on the collagen surface was unaltered, while the number of PS-exposing platelets was significantly reduced (Figure $1 \mathrm{~B}, \mathrm{C})$ With blood from $\mathrm{PI} 3 \mathrm{~K} \gamma-/-$ mice the number of PS-exposing platelets was unchanged in spite of reduced aggregate formation.

It has been shown, using the specific PI3K $\beta$ inhibitor, TGX221, that this isoform is involved in shear- and ADP-dependent platelet adhesion to VWF $^{16}$. We used this compound at a dose of $1 \mu \mathrm{M}$, shown to be selective in whole blood ${ }^{16}$, to study the contribution of $\mathrm{p} 110 \beta(\mathrm{PI} 3 \mathrm{~K} \beta)$ to thrombus formation and platelet procoagulant activity in wildtype and knockout blood. Addition of TGX221 to p85 $\alpha$-/- blood reduced platelet 
deposition but not PS exposure (Figure 1B, C). In contrast, with p110 $\gamma-/$ - blood, TGX221 lowered platelet PS exposure. These results thus demonstrate that both $p 85 \alpha$ and $p 110 \beta$ subunits, but not $\mathrm{p} 110 \gamma$, are involved in collagen- and GPVI-induced PS exposure under flow.

\section{Absence of murine $p 85 \alpha$ and blocking of PI3K $\beta$ reduces and delays GPVI-evoked $\mathrm{Ca}^{2+}$ signaling under flow}

Knowing the relation between GPVI-evoked rises in $\left[\mathrm{Ca}^{2+}\right]_{i}$ and extent of PS exposure under these flow conditions ${ }^{29,30}$, we measured the $\mathrm{Ca}^{2+}$ responses of platelets

A
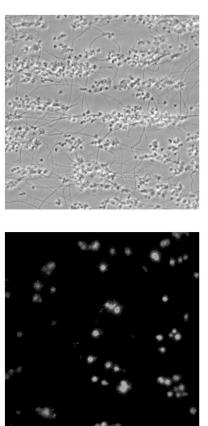

$\mathrm{p} 85 \alpha+/+$
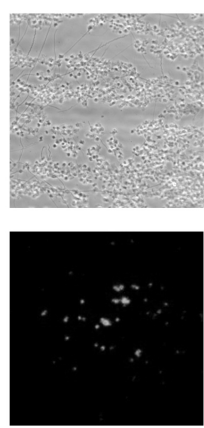

$\mathrm{p} 85 \alpha-/-$
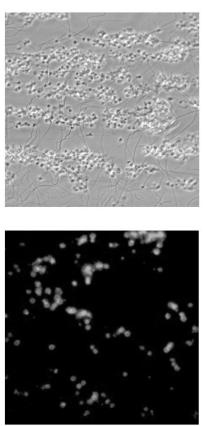

$\mathrm{p} 110 \gamma+/+$
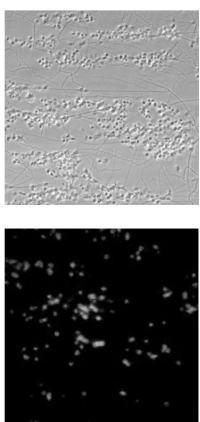

$\mathrm{p} 110 \gamma-/-$
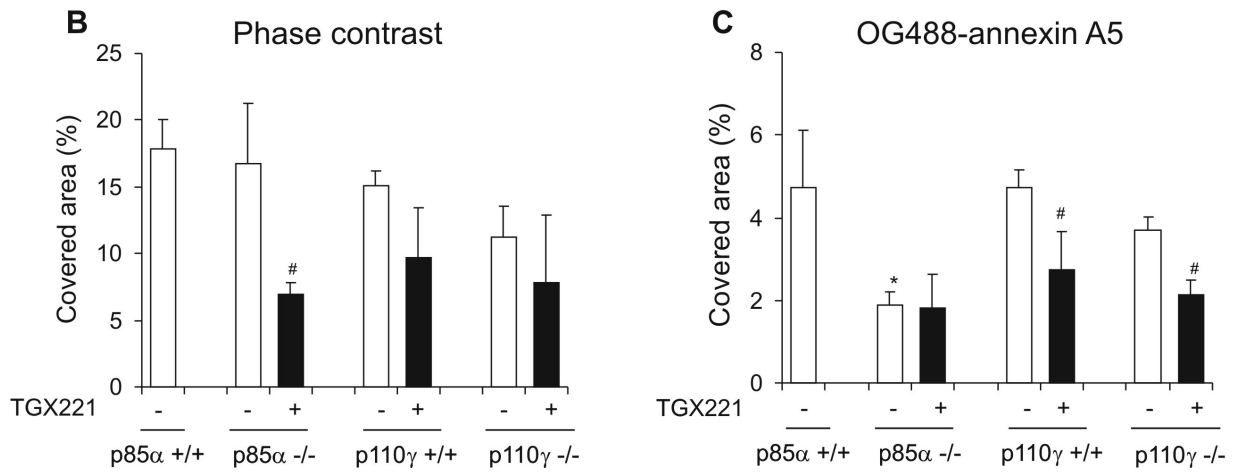

Figure 1 Absence of murine platelet $p 85 \alpha$ but not $p 110 \gamma$ restricts collagen-evoked procoagulant activity under flow. PPACK/heparin-anticoagulated blood from indicated mice was perfused over a collagen surface for $4 \mathrm{~min}$ at $1000 \mathrm{~s}^{-1}$, followed by a 4-min wash with buffer in the presence of fluorescently labelled annexin A5 $(0.5 \mu \mathrm{g} / \mathrm{ml})$. Blood was pre-incubated for $10 \mathrm{~min}$ with $\mathrm{Me}_{2} \mathrm{SO}$ vehicle or PI3K $\beta$ inhibitor TGX221 $(1 \mu \mathrm{M})$, as indicated. (A) Upper panels: representative phase-contrast microscope images of platelet thrombi formed after 4-min perfusion (120×120 $\mu \mathrm{m})$. Lower panels: representative fluorescence images after staining with OG488-labeled annexin A5, detecting PS-exposing platelets $(150 \times 150 \mu \mathrm{m})$. Surface area coverage of all platelets (B) and PSexposing platelets (C) with untreated blood (white bars) or blood treated with TGX221 (black bars). Data are mean \pm SEM $(n=4)$. ${ }^{*} p<0.05$ compared to wildtype; ${ }^{*} p<0.05$ compared to vehicle control. 
adhering to and activated by collagen under flow ${ }^{33}$. Whole blood was spiked with Fluo-3loaded platelets derived from the same mouse strain to reach a concentration of $10 \%$ labelled platelets. Upon perfusion of blood over collagen, wildtype platelets showed a potent and prolonged $\mathrm{Ca}^{2+}$ response (Figure $2 \mathrm{~A}$ ), as is required for PS exposure. Traces from single platelets indicated a rapid rise in $\left[\mathrm{Ca}^{2+}\right]_{\mathrm{i}}$ that was followed by a persistent, elevated plateau level. With blood from p85 $\alpha$ null mice, platelets on average showed lower $\mathrm{Ca}^{2+}$ responses compared to the wildtype cells (Figure 2A, B). Interestingly, averaged traces with platelets from $\mathrm{p} 110 \gamma-/-$ mice showed that initial but not later increases in $\left[\mathrm{Ca}^{2+}\right]_{i}$ were reduced, thus pointing to a delayed response. Indeed, in single cell traces, often a long delay time between stable adhesion and start of the $\mathrm{Ca}^{2+}$ response was observed (Figure $2 \mathrm{~A}$ ).
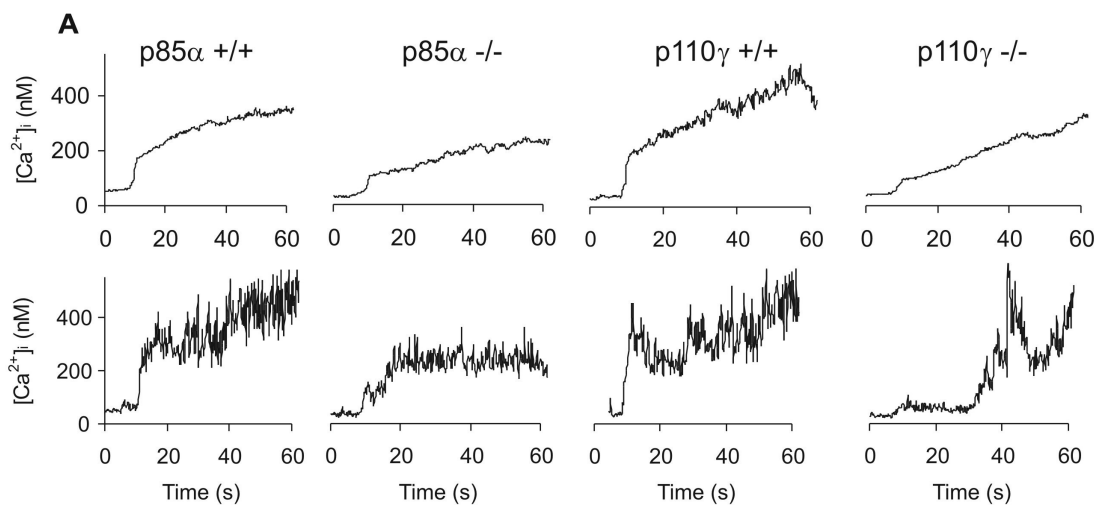

B

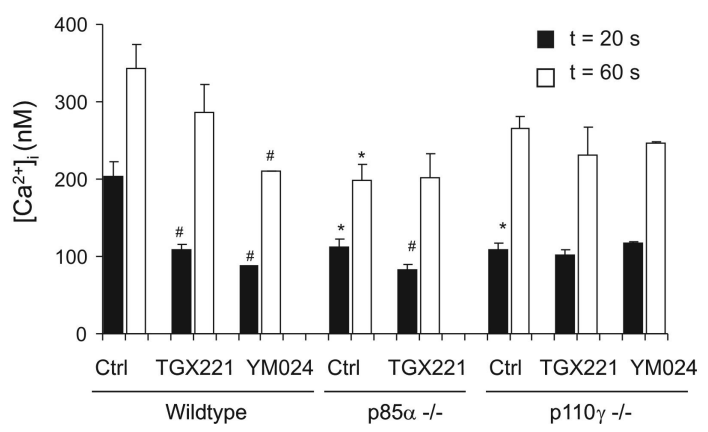

Figure 2 Absence of murine platelet $p 85 \alpha$ or blocking of PI3K $\alpha$ or $\beta$ suppresses collagenevoked $\mathrm{Ca}^{2+}$ responses under flow. Whole murine blood, spiked with $10 \%$ Fluo-3-loaded platelets from the same mouse strain, was perfused over collagen at $1000 \mathrm{~s}^{-1}$. Changes in fluorescence were measured during flow in single, adhered platelets. (A) Upper traces show averaged changes in $\left[\mathrm{Ca}^{2+}\right]_{\mathrm{i}}$, of $15-20$ platelets during $60 \mathrm{~s}$ ( $\geq 3$ mice per condition). Lower traces show $\mathrm{Ca}^{2+}$ responses of representative, single platelets. (B) Blood was pre-incubated with vehicle (Ctrl), PI3K $\alpha$ inhibitor YM024 $(1 \mu \mathrm{M})$ or PI3K $\beta$ inhibitor TGX221 $(1 \mu \mathrm{M})$, as indicated. Quantification is given of changes in $\left[\mathrm{Ca}^{2+}\right]_{\text {, }}$, at $20 \mathrm{~s}$ (black bars) and $60 \mathrm{~s}$ (white bars) after initial increase. Data are mean \pm SEM $(n=3-5)$. ${ }^{*} p<0.05$ compared to wildtype; ${ }^{*} p<0.05$ compared to vehicle control. 
To study the additional contribution of $\mathrm{PI} 3 \mathrm{~K} \beta$ and other class IA isoforms in the GPVI-induced $\mathrm{Ca}^{2+}$ signal generation under flow conditions, the PI3K $\beta$ inhibitor TGX221 and the PI3K $\alpha$ inhibitor YM024 were used. In wildtype mice, TGX221 only reduced the initial phase of the $\mathrm{Ca}^{2+}$ response, while YM024 significantly suppressed the full response to the level observed in platelets from p85 $\alpha-/-$ mice. In these cells, TGX221 still further reduced the initial $\mathrm{Ca}^{2+}$ signal. In platelets from $\mathrm{p} 110 \gamma-/-$ mice, no additional effect of TGX221 or YM024 was observed. Together, these data suggest that p85 $\alpha$ and $\mathrm{p} 110 \alpha(\mathrm{PI} 3 \mathrm{~K} \alpha)$ markedly contribute to the GPVI-evoked $\mathrm{Ca}^{2+}$ responses of platelets on collagen under flow, while the $\beta$ and $\gamma$ PI3K isoforms only contribute to the initial phase of this response.

A
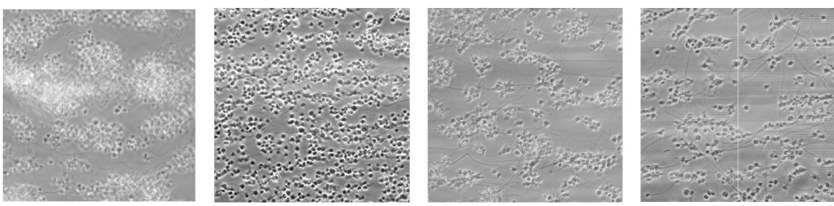

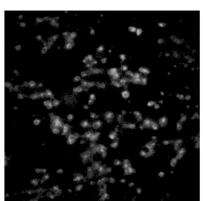

Control

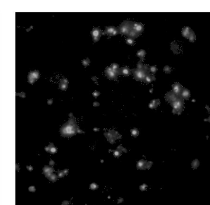

Wortmannin

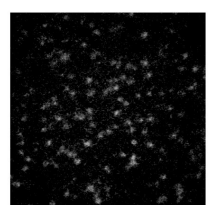

ADP-R block

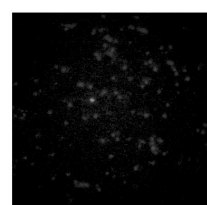

Wortmannin + ADP-R block

B

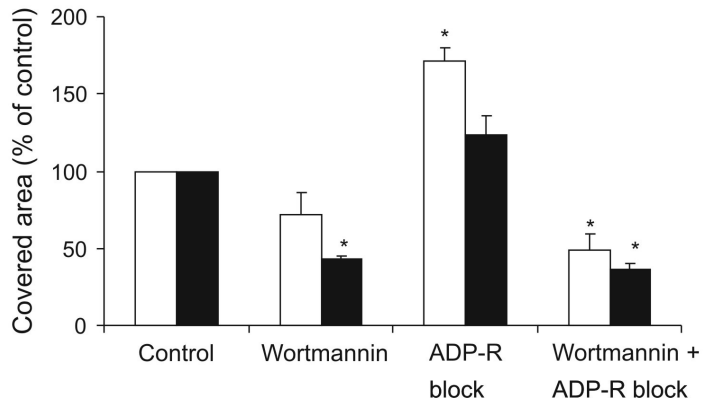

Figure 3 Blocking of human platelet PI3K suppresses collagen-evoked aggregate formation and procoagulant activity under flow. PPACK-anticoagulated human blood was perfused over a collagen surface at $1000 \mathrm{~s}^{-1}$, as indicated for Figure 1. Blood was pre-incubated for 10 min with vehicle (control), wortmannin $(1 \mu \mathrm{M})$ and/or ADP receptor blockers $(40 \mu \mathrm{M}$ MRS2179, $20 \mu \mathrm{M}$ cangrelor and $1 \mathrm{unit} / \mathrm{ml}$ apyrase), where indicated. (A) Upper pane/s: representative phase contrast images after 4-min of perfusion $(120 \times 120 \mu \mathrm{m})$. Lower panels: representative fluorescence images after staining with OG488-annexin A5, detecting PS-exposing platelets $(150 \times 150 \mu \mathrm{m})$. (B) Surface area coverage of all platelets (white bars) and PS-exposing platelets (black bars), expressed as percentages of control condition (mean \pm SEM, $n=4$ ). ${ }^{*} p<0.05$ compared to control. 
Human platelet PI3K contributes to GPVI-evoked aggregate formation, $\mathrm{Ca}^{2+}$ signaling and $P S$ exposure under flow

To investigate the importance of PI3K for the human system, we performed similar flow experiments with PPACK-anticoagulated human blood at a shear rate of $1000 \mathrm{~s}^{-1}$. Under control conditions, platelets rapidly adhered to the collagen fibres and assembled into aggregates, covering much of the collagen surface (Figure 3A). Poststaining with OG488-annexin A5 again revealed many PS-exposing platelets.

Pre-incubation of blood with the high-affinity general PI3K inhibitor wortmannin $(1 \mu \mathrm{M})$ profoundly inhibited the GPVI-evoked aggregation (Figure 3A), but did not affect platelet adhesion to the collagen surface, as surface area coverage of platelets was still about $75 \%$ of the control condition (Figure 3B). In contrast, wortmannin treatment significantly reduced the presence of PS-exposing platelets to $65 \%$ of the control. Similar effects were obtained with another general PI3K inhibitor, LY294002 (not shown).

Because paracrine ADP release contributes to thrombus formation via the ADP.

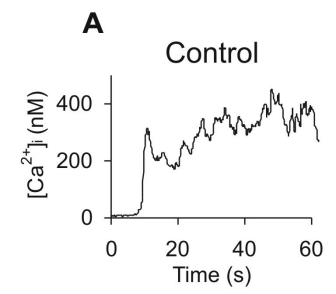

\section{Wortmannin}

\section{ADP-R block}

Wortmannin + ADP-R block
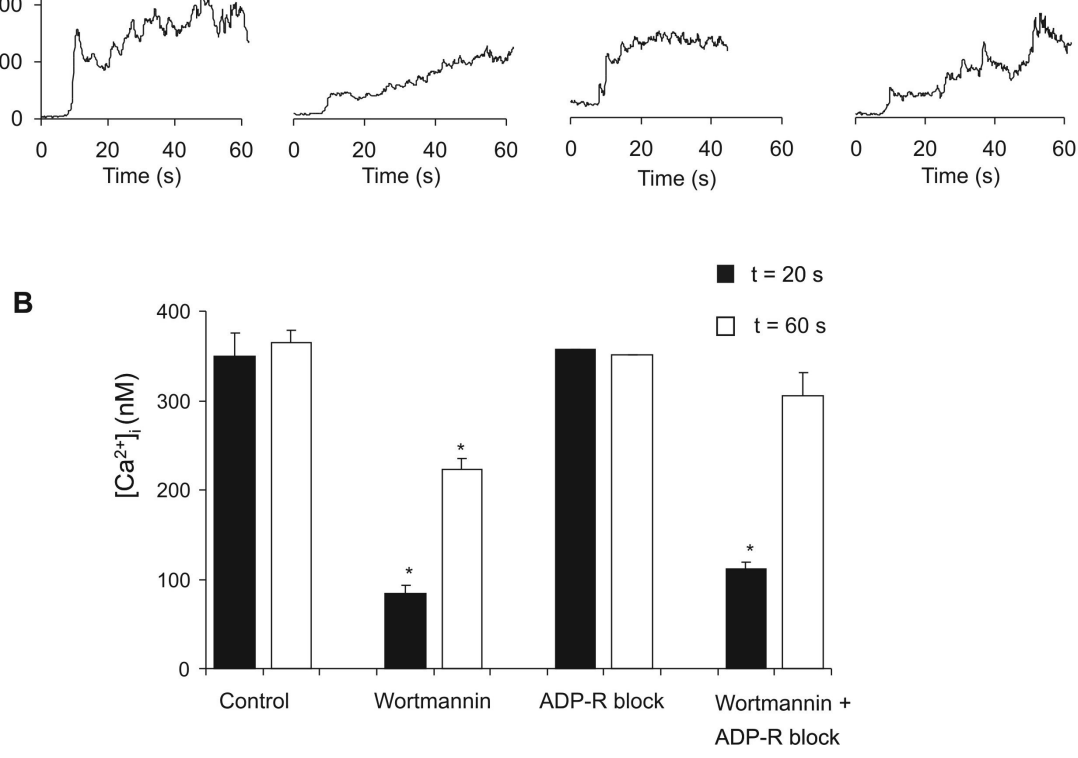

Figure 4 Blocking of human platelet $\mathrm{PI} 3 \mathrm{~K}$ inhibits collagen-evoked $\mathrm{Ca}^{2+}$ responses under flow. Human whole blood was spiked with autologous Fluo-3 loaded platelets, and perfused over collagen, as indicated for Figure 2. Blood was treated with vehicle (control), wortmannin $(1 \mu \mathrm{M})$ and/or ADP receptor blockers (40 $\mu \mathrm{M}$ MRS2179, $20 \mu \mathrm{M}$ cangrelor and $1 \mathrm{U} / \mathrm{ml}$ apyrase), as indicated. (A) Traces of $\left[\mathrm{Ca}^{2+}\right]_{\mathrm{i}}$ changes shown are averaged curves of single-cell responses from $15-25$ platelets. (B) Quantification of changes in $\left[\mathrm{Ca}^{2+}\right]$, at $20 \mathrm{~s}$ (black bars) and $60 \mathrm{~s}$ (white bars) after initial increase. Data are mean \pm SEM $(n=3) .{ }^{*} p<0.05$ compared to control. 
receptors $\mathrm{P}_{2} \mathrm{Y}_{12}$ and $\mathrm{P} 2 \mathrm{Y}_{1}{ }^{38,39}$, and because $\mathrm{PI} 3 \mathrm{~K}$ isoforms play a role in $\mathrm{P} 2 \mathrm{Y}_{12}$-mediated aggregation under flow ${ }^{20}$, we investigated whether ADP release and signaling interfered in the wortmannin effects. Therefore, blood was pre-incubated with saturating doses of ADP-degrading apyrase and the $\mathrm{P}_{2} \mathrm{Y}_{1}$ and $\mathrm{P}_{2} \mathrm{Y}_{12}$ receptor blockers, MRS2179 and cangrelor, respectively. Blockade of the ADP receptors resulted in high deposition of mostly single platelets and small aggregates at the collagen surface (Figure 3A), with as a result a higher surface area coverage with platelets (Figure 3B). However, the ADPreceptor blockade failed to reduce the number of PS-exposing platelets. Interestingly, treatment of wortmannin in combination with ADP receptor blockers reduced platelet deposition, and lowered PS exposure to the level obtained with wortmannin alone. Accordingly, the PI3K contribution to platelet procoagulant activity seems to be independent of indirect, ADP-mediated effects.

Using Fluo-3-loaded platelets, which were added to the human blood, effects of wortmannin and ADP receptor blockade were also investigated on the collagen-evoked $\mathrm{Ca}^{2+}$ responses. As indicated in Figure 4, treatment with wortmannin, but not with ADP receptor blockers, greatly reduces the increases in $\left[\mathrm{Ca}^{2+}\right]_{\mathrm{i}}$. Taken together, these data indicate that under flow blocking of PI3K with wortmannin suppresses collagen-evoked $\mathrm{Ca}^{2+}$ signaling and procoagulant activity, independently of secondary ADP effects.

\section{Human platelet PI3K $\alpha$ and $\beta$ isoforms contribute to GPVI- but not thrombin- evoked $\mathrm{Ca}^{2+}$ mobilisation and entry in platelet suspension}

To more directly investigate the involvement of $\mathrm{PI} 3 \mathrm{~K}$ in agonist-induced $\mathrm{Ca}^{2+}$ signal generation, suspension measurements were performed with washed, Fura-2loaded platelets, which were stimulated by near-maximal doses of the GPVI agonist, CRP $(5 \mu \mathrm{g} / \mathrm{ml})$ or the $\mathrm{G}_{\mathrm{q}}$ protein-coupled receptor agonist, thrombin (10 nM). Platelets were pre-treated with aspirin and contained apyrase to abolish secondary effects due to released thromboxane and ADP, respectively. Activations were in the presence of EGTA to measure only $\mathrm{Ca}^{2+}$ mobilisation from internal stores, while others were with $\mathrm{CaCl}_{2}$, where the $\mathrm{Ca}^{2+}$ signal consists of both internal mobilisation and $\mathrm{Ca}^{2+}$ entry. Doseresponse curves indicated that the general $\mathrm{PI} 3 \mathrm{~K}$ inhibitors reduced the $\mathrm{Ca}^{2+}$ signal evoked by CRP to about $50 \%$, at saturating concentrations of $100 \mathrm{nM}$ wortmannin and $10 \mu \mathrm{M}$ LY294002 (Figure 5A). Furthermore, with either compound a similar dosedependency of inhibition was seen for experiments in the presence of EGTA or $\mathrm{CaCl}_{2}$, thus indicating that internal $\mathrm{Ca}^{2+}$ mobilisation and $\mathrm{Ca}^{2+}$ influx were similarly influenced. Control experiments, performed in the presence of extra MRS2179 (40 $\mu \mathrm{M})$ plus 
cangrelor $(20 \mu \mathrm{M})$ to block $\mathrm{P} 2 \mathrm{Y}$ receptors, gave a similar, maximal inhibition with wortmannin and LY294002 of $45 \pm 1.4 \%$ and $52 \pm 2.8 \%$ of control, respectively. Similar results were obtained when platelets were stimulated with the GPVI agonist, convulxin instead of CRP: wortmannin (10 nM) and LY294002 (1 $\mu \mathrm{M})$ inhibited the $\mathrm{Ca}^{2+}$ response to $37 \pm 0.9$ and $58 \pm 10.4 \%$ of control, respectively. However, in contrast, platelet treatment with wortmannin or LY294002 no more than slightly lowered the $\mathrm{Ca}^{2+}$ responses evoked by thrombin (Figure $5 B$ ).

A panel of currently available high-affinity isoform-specific PI3K inhibitors was then used to established the isoforms contributing to the GPVI-induced $\mathrm{Ca}^{2+}$ response with convulxin in the presence of external $\mathrm{CaCl}_{2}$. The compounds were used at concentrations around their $\mathrm{IC}_{50}$ and higher, as was established in vitro using cell-free

A GPVI activation

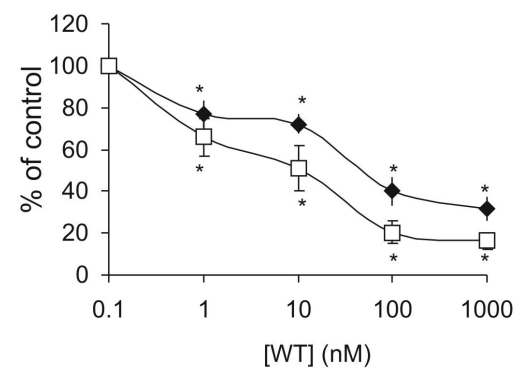

B

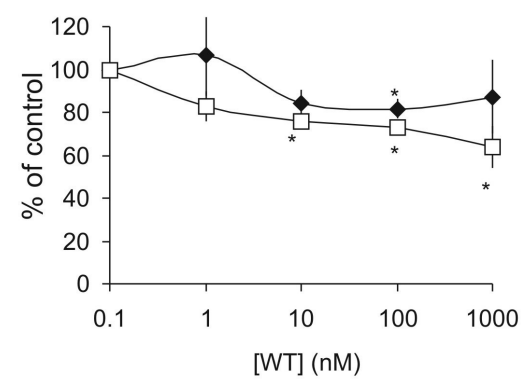

GPVI activation

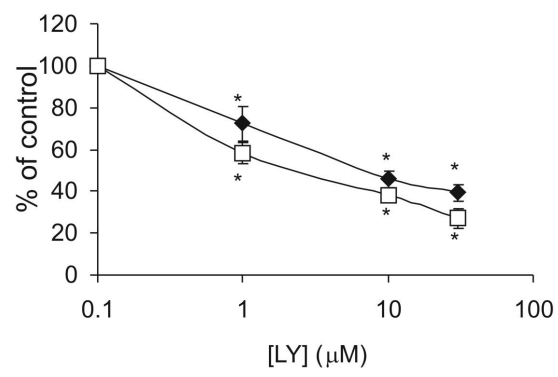

Thrombin

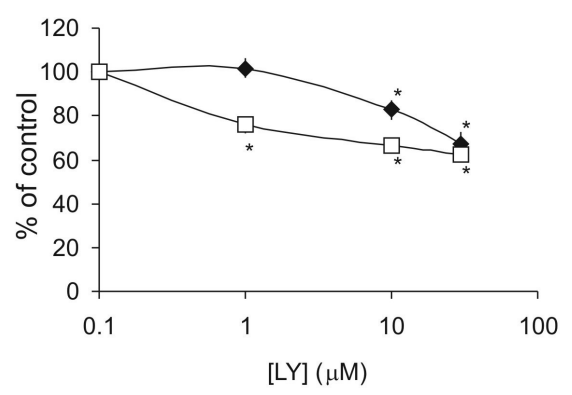

Figure 5 Inhibition of human platelet PI3K suppresses GPVI-, but not thrombin-evoked $\mathrm{Ca}^{2+}$ mobilisation and influx. Suspensions of human, Fura-2-loaded platelets were incubated for 10 min at $37^{\circ} \mathrm{C}$ with $\mathrm{Me}_{2} \mathrm{SO}$ vehicle, wortmannin (0.1-1000 nM) or LY294002 (0.1-30 $\left.\mu \mathrm{M}\right)$. Platelets were then stimulated with (A) GPVI-stimulating CRP $(5 \mu \mathrm{g} / \mathrm{ml})$, or (B) thrombin $(10 \mathrm{nM})$ in buffer containing $1 \mathrm{mM} \mathrm{Ca}^{2+}$ or $1 \mathrm{mM}$ EGTA. The platelets were pre-treated with aspirin while loading with Fura-2, and suspensions contained apyrase. Elevations in $\left[\mathrm{Ca}^{2+}\right]_{i}$ were measured as time$\left[\mathrm{Ca}^{2+}\right]_{i}$ integrals. Black diamonds represent total $\mathrm{Ca}^{2+}$ response with $\mathrm{CaCl}_{2}$, and open squares $\mathrm{Ca}^{2+}$ mobilization with EGTA. Results are expressed as percentages of the vehicle control condition (mean \pm SEM, $n=5)$. ${ }^{*} p<0.05$ compared to control. 
systems ${ }^{28}$. Platelet treatment with the PI3K $\alpha$ inhibitor PI103 (0.02-0.5 $\left.\mu \mathrm{M}\right)$, but not with the analogous control substance, PIK112, resulted in a dose-dependent inhibition of the $\mathrm{Ca}^{2+}$ response up to $50 \%$ of control (Figure $6 \mathrm{~A}$ ). A quite similar effect was obtained with the PI3K $\alpha$ inhibitor, YM024 (0.1-2.5 $\mu \mathrm{M})$.

Also, PI3K $\beta$ inhibition with TGX221 (0.1-2.5 $\mu \mathrm{M})$ gave a $50 \%$ reduction in $\mathrm{Ca}^{2+}$ response. Interestingly, combined inhibition of PI3K $\alpha$ and $\beta$ (PI103 + TGX221) did not have an additional effect, when compared to either inhibitor alone. Platelet treatment with the PI3K $\gamma$ inhibitor AS252424 (0.1-1 $\mu \mathrm{M})$ failed to have an effect on the $\mathrm{Ca}^{2+}$ response, but interfered with the Fura-2 fluorescence at high doses. The compound IC87114 (0.2-5

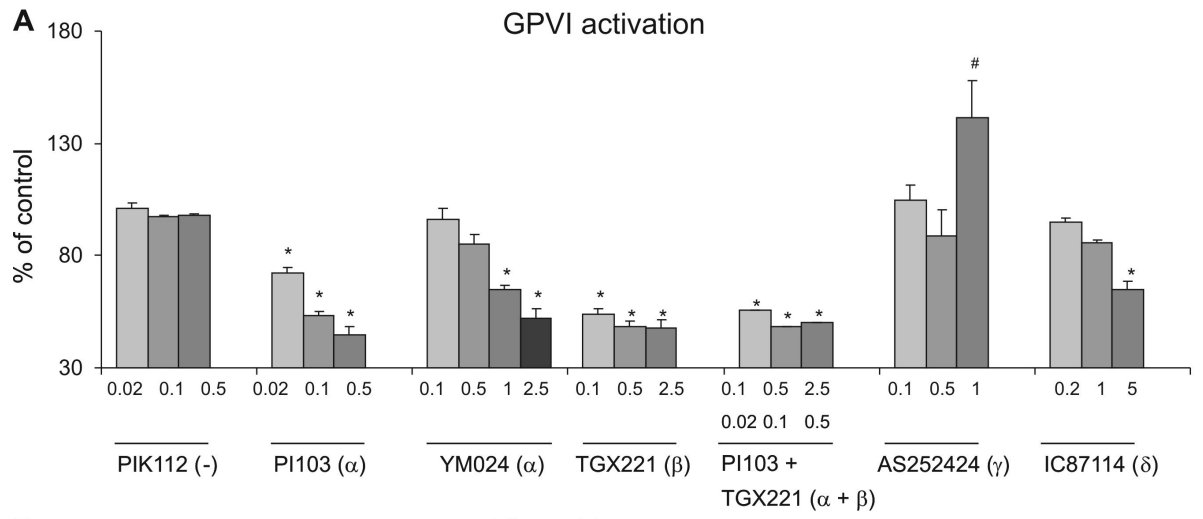

B

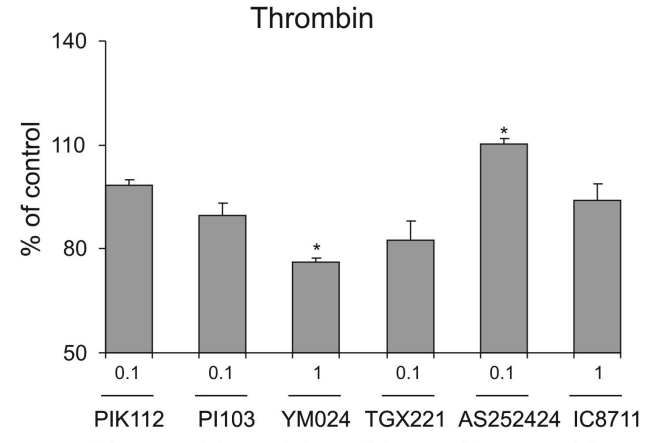
$(-)$
$(\alpha)$
$(\alpha)$
$(\beta)$
$(\gamma)$
(ס)

Figure 6 Inhibition of human platelet PI3K $\alpha$ or $\beta$ suppresses GPVI-, but not thrombin-evoked $\mathrm{Ca}^{2+}$ signaling. Suspensions of human Fura-2-loaded platelets were incubated for 10 min at $37^{\circ} \mathrm{C}$ in the presence of vehicle or one or more of the following inhibitory substances $(0.02-5 \mu \mathrm{M})$ : PIK112 (negative control), PI103 (PI3K $\alpha$ ), YM024 (PI3K $\alpha$ ), TGX221 (PI3K $\beta)$, AS252424 (PI3K $\gamma$ ) or IC87114 (PI3K $\delta$ ) to block indicated PI3K isoforms. Numbers below bars indicate concentrations of inhibitors. Cells were then stimulated with $(A)$ convulxin $(70 \mathrm{ng} / \mathrm{ml})$ or $(B)$ thrombin $(10 \mathrm{nM})$ in Hepes buffer containing $1 \mathrm{mM} \mathrm{CaCl}$. The platelets were pre-treated with aspirin, while loading with Fura-2, and suspensions contained apyrase, MRS2179 and cangrelor. Elevations in $\left[\mathrm{Ca}^{2+}\right]_{i}$ were determined as described for Figure 5. Histograms indicate percentage changes in $\left[\mathrm{Ca}^{2+}\right]_{\mathrm{i}}$ rises relative to control condition. Values are mean \pm SEM from three independent experiments. ${ }^{*} p<0.05$ versus vehicle control, ${ }^{*}$ interference with Fura-2 fluorescence. 
$\mu \mathrm{M})$ slightly, but significantly reduced the GPVI-evoked $\mathrm{Ca}^{2+}$ response only at the highest concentration of $5 \mu \mathrm{M}$, which is still specific for PI3K $\delta$ inhibition. In marked contrast to the profound effects of PI3K $\alpha$ and $\beta$ inhibitors with GPVI agonist, YM024 (1 $\mu \mathrm{M})$ only slightly lowered the $\mathrm{Ca}^{2+}$ response with thrombin (Figure 6B). Thus, inhibition of PI3K $\alpha$ and/or $\beta$, and only weakly of $\delta$, with fair specificity suppressed the $\mathrm{Ca}^{2+}$ response induced by GPVI agonists for up to $50 \%$.

\section{Discussion}

The present results with mouse platelets indicate that absence of the $p 85 \alpha$ regulatory $\mathrm{PI} 3 \mathrm{~K}$ subunit as well as blocking of the $\mathrm{p} 110 \alpha$ or $\mathrm{p} 110 \beta$ activity significantly suppresses $\mathrm{Ca}^{2+}$ signaling and PS exposure elicited by GPVI-induced platelet activation under flow. For platelets from these p $85 \alpha-/-$ mice, it has been established that selective disruption of the p85 $\alpha$ protein does not results in significant up-regulation of the isoform p55 $\alpha, p 50 \alpha$ and p85 $\beta$ proteins to compensate for the lack of p85 $\alpha$. However, in these knock-out platelets expression of the $\mathrm{p} 110 \alpha$ catalytic subunit $(\mathrm{PI} 3 \mathrm{~K} \alpha)$ is almost undetectable, along with a reduced $p 110 \beta$ and $\delta$ expression, resulting in only $5 \%$ kinase activity ${ }^{18,23,40}$. That the class IA isoforms PI3K $\alpha$ and $\beta$ play a role in GPVI-dependent $\mathrm{Ca}^{2+}$ signaling was confirmed by the suppressive effects of PI103/YM024 and TGX221 which block the $p 110 \alpha$ and $p 110 \beta$ subunits with preference, respectively. However, it should be noted that the PI3K $\alpha$ inhibitors, PI103 and YM024, also have limited inhibitory activity towards $\mathrm{PI} 3 \mathrm{~K} \beta$ (S. Jackson, unpublished results). The PI3K $\beta$ inhibitor TGX221 was unable to further suppress the lower $\mathrm{Ca}^{2+}$ signal in $\mathrm{p} 85 \alpha-/-$ platelets. Importantly, these compounds showed the same degree of inhibition on GPVI-induced (with convulxin) $\mathrm{Ca}^{2+}$ responses in human platelets, thus indicating that the isoform-specific regulation of this signaling pathway is conserved in mouse and human platelets. Earlier work has demonstrated that collagen activation results in association of p85 $\alpha$ with the LAT adaptor protein ${ }^{41}$, and that absence of $\mathrm{p} 85 \alpha$ results in defective collagen-induced platelet aggregation and degranulation ${ }^{18}$. The current findings significantly extend this, and indicate that $\mathrm{p} 85 \alpha$ acts by activating $\mathrm{p} 110 \alpha / \beta$, which potentiate GPVI-induced $\mathrm{Ca}^{2+}$ signaling and PS exposure.

Previous studies have shown that GPVI agonist like collagen and CRP stimulate the formation of $\mathrm{PIP}_{3}$ and $\mathrm{PI}(3,4) \mathrm{P}_{3}$ in human platelets, and that this stimulation is antagonized by wortmannin and LY294002, two structurally unrelated inhibitors of all platelet $\mathrm{PI} 3 \mathrm{~K}$ isoforms. Indeed, it has been shown that $\mathrm{PI} 3 \mathrm{~K}$ activity and $\mathrm{PIP}_{3}$ formation 
are required for full activation of PLC $\gamma 2$ in response to GPVI stimulation ${ }^{8,42,43}$. Interestingly, the present data with mouse and human platelets indicate that combined inhibition of $\mathrm{PI} 3 \mathrm{~K} \alpha$ and $\beta$ gives a similar reduction in $\mathrm{Ca}^{2+}$ response, and hence in PLC $\gamma 2$ activity, as inhibition of either isoform alone. While this finding agrees with the concept that the $\mathrm{PI} 3 \mathrm{~K}$ product $\mathrm{PIP}_{3}$ acts as a membrane anchoring site of $\mathrm{PLC} \gamma 2$, it argues against a redundancy in function of the two PI3K isoforms. One explanation is that threshold levels of $\mathrm{PIP}_{3}$ need to be formed - i.e. by simultaneous activity of either isoform - in order to anchor and stimulate PLC $\gamma 2$, perhaps because of its competition with other $\mathrm{PH}$-domain containing signaling proteins. Thus, the activity of both PI3K isoforms is needed to reach sufficient lipid kinase activity.

In contrast to $\mathrm{PI} 3 \mathrm{~K} \alpha$ and $\beta$, the class IA PI3K $\delta$ and the class IB PI3K $\gamma$ appeared to have a less prominent role in GPVI-induced $\mathrm{Ca}^{2+}$ responses. In human platelets, the PI3K $\delta$ inhibitor IC87114 provoked a small reduction of the $\mathrm{Ca}^{2+}$ signal, but not the PI3K $\gamma$ inhibitor AS252424. This is in agreement with recent data with platelets from PI3K $\delta$ deficient mice, which point to a small but detectable role for the $\delta$ isoform in mediating platelet activation by collagen ${ }^{44}$. Typically, under flow conditions, absence of murine p110 $\gamma$ resulted in a collagen-induced $\mathrm{Ca}^{2+}$ signal, which was only initially reduced in comparison to that of wildtype platelets. This appeared to be due to an often prolonged delay time between adhesion and start of the $\mathrm{Ca}^{2+}$ signal, thus pointing to a delayed onset in GPVI signaling under flow rather than to a reduction in GPVI signaling per se. This conclusion is also supported by the observation that GPVI-induced and $\mathrm{Ca}^{2+}$. mediated PS exposure of platelets is not reduced in the absence of $p 110 \gamma$.

We and others have shown that both the PI3K $\beta$ and $\gamma$ isoforms play an enhancing role in ADP-induced integrin $\alpha \operatorname{llb} \beta 3$ activation, stable adhesion and thrombus stabilization under static and flow conditions ${ }^{16,19,20}$. This was also apparent in the present experiments, i.e. from the reducing effects of wortmannin and ADP receptor blockage on human platelet aggregate formation under flow. However, these ADP-mediated effects of PI3K are independent of the GPVI-mediated effects, because wortmannin still suppresses collagen-induced $\mathrm{Ca}^{2+}$ responses and PS exposure under conditions of full blockade of the ADP receptor blockers (MRS2179, cangrelor and apyrase). Similarly, in platelet suspensions, the general PI3K inhibitors, wortmannin and LY294002, and the isoform-specific inhibitors, PI103, YM024 and TGX221, suppress GPVI-induced $\mathrm{Ca}^{2+}$ signaling up to $50 \%$, again under conditions where ADP receptors are blocked. This high involvement of $\mathrm{PI} 3 \mathrm{~K}$ in $\mathrm{Ca}^{2+}$ rises was specific for GPVI signaling, as the same inhibitors had only a small, reducing effect on thrombin-evoked $\mathrm{Ca}^{2+}$ rises. This agrees well with 
the earlier observation that thrombin mobilises $\mathrm{Ca}^{2+}$ nearly entirely via PLC $\beta$ isoforms with only little contribution of PLC $\gamma 1^{5,45}$.

Dose-response curves with either wortmannin or LY294002 showed a similar degree of inhibition of GPVI-mediated $\mathrm{Ca}^{2+}$ responses in the presence of EGTA (measuring only internal $\mathrm{Ca}^{2+}$ mobilisation) and $\mathrm{CaCl}_{2}$ (recording both $\mathrm{Ca}^{2+}$ mobilisation and $\mathrm{Ca}^{2+}$ influx from the external medium). This argues against a specific stimulation of platelet PI3Ks on $\mathrm{Ca}^{2+}$ entry processes. Moreover, wortmannin or LY294002 also failed to give extra inhibition of thrombin-induced $\mathrm{Ca}^{2+}$ responses, when $\mathrm{Ca}^{2+}$ entry was allowed in the presence of $\mathrm{CaCl}_{2}$. Accordingly, our results do not support the earlier suggestion by others that $\mathrm{PI} 3 \mathrm{~K}$ phosphoinositides, e.g. as generated by stimulation of GPVI or thrombin receptors, stimulate a specific pathway of $\mathrm{Ca}^{2+}$ entry ${ }^{21,22}$. This discrepancy may come from the higher doses of LY294002 or wortmannin used by Lu et al., at which also PI4-K activity and, thus, e.g. $\mathrm{PIP}_{2}$ formation is affected ${ }^{46}$. Further, it is possible that increased $\mathrm{Ca}^{2+}$ influx, noted in the absence of the $\mathrm{PIP}_{3}$-degrading $\mathrm{SH} 2$ domain-containing inositol 5-phosphatase $(\mathrm{SHIP})^{22}$, is caused by a distinct mechanism than that influenced by PI3Ks, e.g. related to the higher basal $\mathrm{Ca}^{2+}$ levels in SHIP -/- mice.

Taken together, the present results indicate that the principle mechanism of action of PI3K on GPVI-induced $\mathrm{Ca}^{2+}$ signaling and PS exposure is by enhancement of PLC $\gamma 2$-mediated stimulation of $\mathrm{Ca}^{2+}$ depletion from internal stores, and subsequent store-mediated $\mathrm{Ca}^{2+}$ entry. Furthermore, particularly the $\mathrm{PI} 3 \mathrm{~K} \alpha$ and $\beta$ isoforms, acting via $\mathrm{p} 85 \alpha$, appear to be involved in this activation pathway, with $\mathrm{PKI} 3 \delta$ playing a minor role.

\section{Acknowledgement}

We acknowledge dr. R. Wetzker for kindly providing PI3K $\gamma$ deficient mice. This work is supported by the Netherlands Heart Foundation (2002-B014) and the Netherlands Organization for Scientific Research (902-16-276). 


\section{References}

1. Heemskerk JWM. Calcium and platelets. In: The Molecular Basis of Calcium Action in Biology and Medicine (Pochet, R, Donato, R, Haiech, J, Heinzmann, C and Gerke, V, eds), Kluwer Acad Publ, The Hague (the Netherlands). 2000:45-71.

2. Rosado JA, Sage SO. The ERK cascade, a new pathway involved in the activation of storemediated calcium entry in human platelets. Trends Cardiovasc Med. 2002;12:229-232.

3. Heemskerk JWM, Kuijpers MJE, Munnix ICA, Siljander PRM. Platelet collagen receptors and coagulation. A characteristic platelet response as possible target for antithrombotic treatment. Trends Cardiovasc Med. 2005;15:86-92.

4. Heemskerk JWM, Bevers EM, Lindhout T. Platelet activation and blood coagulation. Thromb Haemost. 2002;88:186-193.

5. Offermanns S, Toombs CF, Hu YH, Simon MI. Defective platelet-activation in Gaq-deficient mice. Nature. 1997;389:183-186.

6. Rhee SG, Bae YS. Regulation of phosphoinositide-specific phospholipase C isozymes. J Biol Chem. 1997;272:15045-15048.

7. Smeets EF, Heemskerk JW, Comfurius P, Bevers EM, Zwaal RF. Thapsigargin amplifies the platelet procoagulant response caused by thrombin. Thromb Haemost. 1993;70:1024-1029.

8. Pasquet JM, Bobe R, Gross B, Gratacap MP, Tomlinson MG, Payrastre B, Watson SP. A collagen-related peptide regulates phospholipase $C_{\gamma} 2$ via phosphatidylinositol 3-kinase in human platelets. Biochem J. 1999;342:171-177.

9. Watson SP, Gibbins JM. Collagen receptor signaling in platelets: extending the role of the ITAM. Immunol Today. 1998;19

10. Nieswandt B, Watson SP. Platelet-collagen interaction: is GPVI the central receptor? Blood. 2003;102:449-461.

11. Bae YS, Cantley LG, Chen CS, Kim SR, Kwon KS, Rhee SG. Activation of phospholipase C $\gamma$ by phosphatidylinositol 3,4,5-trisphosphate. J Biol Chem. 1998;273:4465-4469.

12. Schlessinger J. Cell signaling by receptor tyrosine kinases. Cell. 2000;103:211-225.

13. Scharenberg AM, Kinet JP. Ptdlns-3,4,5- $\mathrm{P}_{3}$, a regulatory nexus between tyrosine kinases and sustained calcium signals. Cell. 1998;94:5-8.

14. Rittenhouse SE. Phosphoinositide 3-kinase activation and platelet function. Blood. 1996;88:4401-4414.

15. Vanhaesebroeck B, Waterfield MD. Signaling by distinct classes of phosphoinositide 3kinases. Exp Cell Res. 1999;253:239-254.

16. Jackson SP, Schoenwaelder SM, Goncalves I, Nesbitt WS, Yap CL, Wright CE, Kenche V, Anderson KE, Dopheide SM, Yuan Y, Sturgeon SA, Prabaharan H, Thompson PE, Smith GD, Shepherd PR, Daniele N, Kulkarni S, Abbott B, Saylik D, Jones C, Lu L, Giuliano S, Hughan SC, Angus JA, Robertson AD, Salem HH. PI 3-kinase p110ß: a new target for antithrombotic therapy. Nat Med. 2005;11:507-514.

17. Gratacap MP, Payrastre B, Viala C, Mauco G, Plantavid M, Chap H. Phosphatidylinositol 3,4,5-trisphosphate-dependent stimulation of phospholipase $\mathrm{C} \gamma 2$ is an early key event in FcyRIIA-mediated activation of human platelets. J Biol Chem. 1998;273:24314-24321.

18. Watanabe N, Nakajima H, Suzuki H, Oda A, Matsubara Y, Moroi M, Terauchi Y, Kadowaki T, Suzuki H, Koyasu S, Ikeda Y, Handa M. Functional phenotype of phosphoinositide 3-kinase p85 $\alpha$-null platelets characterized by an impaired response to GPVI stimulation. Blood. 2003;102:541-548.

19. Hirsch E, Bosco O, Tropel P, Laffargue M, Calvez R, Altruda F, Wymann M, Montrucchio G. Resistance to thromboembolism in PI3K $\gamma$-deficient mice. Faseb J. 2001;15:2019-2021.

20. Cosemans JMEM, Munnix ICA, Wetzker R, Heller R, Jackson SP, Heemskerk JWM Continuous signaling via PI3K isoforms $\beta$ and $\gamma$ is required for platelet ADP receptor function in dynamic thrombus stabilization. Blood. 2006;108:3045-3052. 
21. Lu PJ, Hsu AL, Wang DS, Chen CS. Phosphatidylinositol 3,4,5-trisphosphate triggers platelet aggregation by activating $\mathrm{Ca}^{2+}$ influx. Biochemistry. 1998;37:9776-9783.

22. Pasquet JM, Quek L, Stevens C, Bobe R, Huber M, Duronio V, Krystal G, Watson SP. Phosphatidylinositol 3,4,5-trisphosphate regulates $\mathrm{Ca}^{2+}$ entry via Btk in platelets and megakaryocytes without increasing phospholipase C activity. EMBO J. 2000;19:2793-2802.

23. Suzuki H, Terauchi Y, Fujiwara M, Aizawa S, Yazaki Y, Kadowaki T, Koyasu S. Xid-like immunodeficiency in mice with disruption of the p85 $\alpha$ subunit of phosphoinositide 3-kinase. Science. 1999;283:390-392.

24. Hirsch E, Katanaev VL, Garlanda C, Azzolino O, Pirola L, Silengo L, Sozzani S, Mantovani A, Altruda F, Wymann MP. Central role for G protein-coupled phosphoinositide 3-kinase $\gamma$ in inflammation. Science. 2000;287:1049-1053.

25. Morton LF, Hargreaves PG, Farndale RW, Young RD, Barnes MJ. Integrin $\alpha 2 \beta 1$-independent activation of platelets by simple collagen-like peptides, collagen tertiary (triple-helical) and quaternary (polymeric) structures are sufficient alone for $\alpha 2 \beta 1$-independent platelet reactivity. Biochem J. 1995;306:337-344.

26. Jandrot-Perrus M, Lagrue AH, Okuma M, Bon C. Adhesion and activation of human platelets induced by convulxin involve glycoprotein $\mathrm{VI}$ and integrin $\alpha 2 \beta 1 . \mathrm{J}$ Biol Chem. 1997;272:27035-27041.

27. Siljander P, Farndale RW, Feijge MAH, Comfurius P, Kos S, Bevers EM, Heemskerk JWM. Platelet adhesion enhances the glycoprotein VI-dependent procoagulant response: involvement of p38 MAP kinase and calpain. Arterioscler Thromb Vasc Biol. 2001;21:618-627.

28. Condliffe AM, Davidson K, Anderson KE, Ellson CD, Crabbe T, Okkenhaug K, Vanhaesebroeck B, Turner M, Webb L, Wymann MP, Hirsch E, Ruckle T, Camps M, Rommel C, Jackson SP, Chilvers ER, Stephens LR, Hawkins PT. Sequential activation of class IB and class IA PI3K is important for the primed respiratory burst of human but not murine neutrophils. Blood. 2005;106:1432-1440.

29. Kuijpers MJE, Schulte V, Bergmeier WG, Lindhout T, Brakebusch C, Offermanns S, Fässler R, Heemskerk JWM, Nieswandt B. Complementary roles of platelet glycoprotein VI and $\alpha 2 \beta 1$ integrin in collagen-dependent thrombus formation. FASEB J. 2003;17:685-687.

30. Siljander PRM, Munnix ICA, Smethurst PA, Deckmyn H, Lindhout T, Ouwehand WH, Farndale RW, Heemskerk JWM. Platelet receptor interplay regulates collagen-induced thrombus formation in flowing human blood. Blood. 2004;103:1333-1341.

31. Munnix ICA, Strehl A, Kuijpers MJE, Auger JM, van der Meijden PEJ, van Zandvoort MAM, oude Egbrink MGA, Nieswandt B, Heemskerk JWM. The glycoprotein VI-phospholipase C $\gamma 2$ signaling pathway controls thrombus formation induced by collagen and tissue factor in vitro and in vivo. Arterioscler Thromb Vasc Biol. 2005;25:2673-2678.

32. Auger JM, Kuijpers MJ, Senis YA, Watson SP, Heemskerk JW. Adhesion of human and mouse platelets to collagen under shear: a unifying model. FASEB J. 2005;19:825-827.

33. Heemskerk JWM, Willems GM, Rook MB, Sage SO. Ragged spiking of free calcium in ADPstimulated human platelets: regulation of puff-like calcium signals in vitro and ex vivo. $\mathrm{J}$ Physiol. 2001;535:625-635.

34. Sargeant $P$, Farndale RW, Sage SO. The tyrosine kinase inhibitors methyl 2,5dihydroxycinnamate and genistein reduce thrombin-evoked tyrosine phosphorylation and $\mathrm{Ca}^{2+}$ entry in human platelets. FEBS Lett. 1993;315:242-246.

35. Rosado JA, Borwnlow SL, Sage SO. Endogenously expressed Trp1 is involved in storemediated $\mathrm{Ca}^{2+}$ entry by conformational coupling in human platelets. J Biol Chem. 2002;277:42157-42163.

36. Grynkiewicz G, Poenie M, Tsien RY. A new generation of $\mathrm{Ca}^{2+}$ indicators with greatly improved fluorescence properties. J Biol Chem. 1985;260:3440-3450.

37. Heemskerk JWM, Feijge MAH, Henneman L, Rosing J, Hemker HC. The $\mathrm{Ca}^{2+}$-mobilizing potency of $\alpha$-thrombin and thrombin-receptor-activating peptide on human platelets. Eur $\mathrm{J}$ Biochem. 1997;249:547-555. 
38. Lecut C, Schoolmeester A, Kuijpers MJ, Broers JL, van Zandvoort MA, Vanhoorelbeke K, Deckmyn H, Jandrot-Perrus M, Heemskerk JW. Principal role of glycoprotein VI in $\alpha 2 \beta 1$ and $\alpha$ llb $\beta 3$ activation during collagen-induced thrombus formation. Arterioscler Thromb Vasc Biol. 2004;24:1727-1733.

39. Remijn JA, Wu YP, Heninga EH, IJsseldijk MJW, van Willigen G, de Groot PG, Sixma JJ, Nurden AT, Nurden P. Role of ADP receptor P2Y 12 in platelet adhesion and thrombus formation in flowing blood. Arterioscler Thromb Vasc Biol. 2002;22:686-691.

40. Terauchi $Y$, Tsuji $Y$, Satoh S, Minoura H, Murakami K, Okuno A, Inukai K, Asano T, Kaburagi Y, Ueki K, Nakajima H, Hanafusa T, Matsuzawa Y, Sekihara H, Yin Y, Barrett JC, Oda H, Ishikawa T, Akanuma Y, Komuro I, Suzuki M, Yamamura K, Kodama T, Suzuki H, Yamamura K, Kodama T, Suzuki H, Koyasu S, Aizawa S, Tobe K, Fukui Y, Yazaki Y, Kadowaki T. Increased insulin sensitivity and hypoglycaemia in mice lacking the p85 $\alpha$ subunit of phosphoinositide 3-kinase. Nat Genet. 1999;21:230-235.

41. Gibbins JM, Briddon S, Shutes A, van Vugt MJ, van de Winkel JG, Saito T, Watson SP. The p85 subunit of phosphatidylinositol 3-kinase associates with the Fc receptor $\gamma$-chain and linker for activitor of T cells (LAT) in platelets stimulated by collagen and convulxin. J Biol Chem. 1998;273:34437-34443.

42. Lagrue AH, Francischetti IM, Guimaraes JA, Jandrot-Perrus M. Phosphatidylinositol 3-kinase and tyrosine-phosphatase activation positively modulate convulxin-induced platelet activation. Comparison with collagen. FEBS Lett. 1999;448:95-100.

43. Falet H, Barkalow KL, Pivniouk VI, Barnes MJ, Geha RS, Hartwig JH. Roles of SLP-76, phosphoinositide 3-kinase, and gelsolin in the platelet shape changes initiated by the collagen receptor GPVI/FcR $\gamma$-chain complex. Blood. 2000;96:3786-3792.

44. Senis YA, Atkinson BT, Pearce AC, Wonerow P, Auger JM, Okkenhaug K, Pearce W, Vigorito E, Vanhaesebroeck B, Turner M, Watson SP. Role of the p110 PI 3-kinase in integrin and ITAM receptor signaling in platelets. Platelets. 2005;16:191-202.

45. Baldassare JJ, Henderson PA, Tarver A, Fisher GJ. Thrombin activation of human platelets dissociates a complex containing gelsolin and actin from phosphatidylinositide-specific phospholipase C $\gamma 1$. Biochem J. 1997;324:283-287.

46. Rosado JA, Sage SO. Phosphoinositides are required for store-mediated calcium entry in human platelets. J Biol Chem. 2000;275:9110-9113. 


\section{Chapter 4}

\section{Platelet receptor interplay regulates collagen-induced thrombus formation in flowing human blood}

Pia R. M. Siljander, Imke C. A. Munnix, Peter A. Smethurst, Hans Deckmyn, Theo Lindhout, Willem H. Ouwehand, Richard W. Farndale and Johan W. M. Heemskerk

This research was originally published in Blood

Blood 2004; 103:1333-1341

(c) the American Society of Hematology 


\section{Abstract}

The platelet glycoproteins (GPs) lb, integrin $\alpha 2 \beta 1$, and GPVI are considered central to thrombus formation. Recently, their relative importance has been re-evaluated based on data from murine knockout models. To examine their relationship during human thrombus formation on collagen type I fibers at high shear $\left(1000 \mathrm{~s}^{-1}\right)$, we tested a novel antibody against GPVI, an immunoglobulin single-chain variable fragment, 10B12, together with specific antagonists for GPIb $\alpha\left(12 \mathrm{G} 1 \mathrm{Fab}_{2}\right)$ and $\alpha 2 \beta 1$ (6F1 mAb or GFOGER-GPP peptide). GPVI was found to be crucial for aggregate formation, $\mathrm{Ca}^{2+}$ signaling, and phosphatidylserine (PS) exposure, but not for primary adhesion, even with more than $97 \%$ receptor blockade. Inhibiting $\alpha 2 \beta 1$ revealed its involvement in regulating $\mathrm{Ca}^{2+}$ signaling, PS exposure, and aggregate size. Both GPlb $\alpha$ and $\alpha 2 \beta 1$ contributed to primary adhesion, showing overlapping function. The coinhibition of receptors revealed synergism in thrombus formation: the coinhibition of adenosine diphosphate (ADP) receptors with collagen receptors further decreased adhesion and aggregation, and, crucially, the complete eradication of thrombus formation required the coinhibition of GPVI with either GPIb $\alpha$ or $\alpha 2 \beta 1$. In summary, human platelet deposition on collagen depends on the concerted interplay of several receptors: GPIb in synergy with $\alpha 2 \beta 1$ mediating primary adhesion, reinforced by activation through GPVI, which further regulates the thrombus formation.

\section{Introduction}

The platelet response to exposed subendothelial matrix is fundamental to thrombosis and hemostasis. Uniquely, collagen, the most abundant vessel wall protein, mediates platelet adhesion and activation, localizing and regulating the hemostatic response at sites of injury. Discovering the molecular mechanisms that control plateletcollagen interaction is crucial for understanding the pathogenesis of arteriothrombotic diseases such as stroke and myocardial infarction. Under high shear rate conditions, the glycoprotein (GP) lb/V/IX complex allows initial platelet rolling over von Willebrand factor (VWF) bound to subendothelial collagen fibers, and subsequently collagen receptors come into contact with their specific binding sequences in the collagen. For the next step, platelet arrest and activation, firm evidence exists of a role for only 2 receptors, integrin $\alpha 2 \beta 1$ and immunoglobulin superfamily member GPVI, despite the apparent redundancy in collagen receptors (for a review, see Siljander PRM and Farndale RW ${ }^{1}$ ). 
According to the 2-site, 2-step model, high-affinity interaction through $\alpha 2 \beta 1$ stops the platelet, allowing low-affinity binding of GPVI, which generates signaling required for the subsequent thrombus formation. Platelet deposition under flow was found to be dependent on GPIb/V/IX and $\alpha 2 \beta 1^{2-4}$, whereas no platelet deposition occurred on the GPVI-specific substrate collagen-related peptide (CRP), even under low shear rates $^{5}$. The limited number of studies with human platelets deficient in either GPVI or $\alpha 2 \beta 1$ support the 2-site, 2-step model. Blood depleted of functional GPVI showed only severe impairment of the collagen-induced "second-wave" aggregation response under flow $^{6}$. Although thrombus volume was reduced, the initial adhesive layer of platelets was fully preserved. The few patients with defective $\alpha 2 \beta 1$ displayed bleeding problems, suggesting a central role for the integrin in hemostasis ${ }^{7-10}$. Genetic diversity of $\alpha 2 \beta 1$ expression also correlates with predisposition to thrombotic events (for a review, see Kunicki $\mathrm{TJ}^{11}$ ). Recently, several lines of evidence strongly encouraged revision of the step-wise model, promoting the idea that GPVI is the primary collagen receptor. Integrin $\alpha 2 \beta 1$ was found to change its affinity for collagen when stimulated by noncollagenous agonists such as adenosine diphosphate (ADP) or thrombin, or through $\mathrm{GPVI}^{12}$, implying that high-affinity interaction through $\alpha 2 \beta 1$ requires the involvement of platelet receptors that induce secretion or inside-out signaling. Moreover, mice with Cre/loxP-mediated loss of $\alpha 2 \beta 1$ from the platelets displayed undisturbed bleeding times, and their platelets exhibited normal collagen adhesion and signaling ${ }^{13}$. Similarly, $\alpha 2(-/-)$ mice showed no changes in platelet aggregation and adhesion to fibrillar collagen ${ }^{14}$, whereas Fc $\gamma(-/-)$ mice, generating a deficiency in the coexpressed GPVI, completely lacked a response to collagen under flow, as did wild-type mouse blood incubated with an anti-GPVI monoclonal antibody (mAb), indicating a key role for GPVI ${ }^{13}$.

Following the deposition of platelets, their procoagulant response is essential for thrombus formation. Platelet aggregates are stabilized through fibrin formation, and newly generated thrombin recruits further platelets and activates other cells. At an advanced stage of activation, collagen-adherent platelets undergo a procoagulant transformation that includes the exposure of phosphatidylserine (PS), the secretion of coagulation factors, and the distinctive morphology of blebbing cells and microvesiculation ${ }^{15}$. We have previously shown that GPVI is essential for triggering this response in collagen-adherent platelets, which is preceded by extensive intracellular $\mathrm{Ca}^{2+}$-signaling ${ }^{16}$. Supporting this, prothrombinase activity was shown to correlate with GPVI density ${ }^{17}$ and genotype ${ }^{18}$. 
This study was undertaken to clarify the role of the human collagen receptors GPVI and $\alpha 2 \beta 1$ in thrombus formation under flow. Studies with GPVI have been hindered by the lack of antagonists of human GPVI. Recently, 10B12, an anti-GPVI, single-chain, variable domain antibody fragment (scFv) was cloned by phage display from a library of human immunoglobulin variable domains, using its capacity to block the recombinant GPVI-CRP interaction ${ }^{19}$. Because it blocks CRP- and fibrillar collageninduced platelet activation, 10B12 provides a small and efficient tool for human studies. To inhibit $\alpha 2 \beta 1$ function, a collagen-derived triple-helical peptide, GFOGER-GPP ${ }^{20}$, was used along with well-defined inhibitory $m \mathrm{Abs}^{21,22}$. Simultaneous ADP and collagen receptor antagonism were also studied. Under high shear rate conditions, specific parameters of thrombus formation-surface coverage of platelets, aggregate size distribution, and PS exposure-were monitored. Further, the intracellular $\mathrm{Ca}^{2+}$ response, which regulates these platelet processes and secretion and thromboxane $A_{2}\left(T x A_{2}\right)$ production, was measured from adherent platelets.

Our results show that GPVI is crucial to collagen-induced $\mathrm{Ca}^{2+}$ responses, aggregate formation, and PS expression but that $\alpha 2 \beta 1$ also contributes to these processes. Although GPVI is not directly involved in primary platelet adhesion to collagen, the inhibition of GPVI, along with GPIb and $\alpha 2 \beta 1$, was mandatory to eradicate thrombus formation.

\section{Materials and methods}

\section{Materials}

Fibrillar type I collagen (Horm) from equine tendon was obtained from Nycomed (Munich, Germany). Apyrase (grade 7), heparin, and MRS2179, a P2Y 1 antagonist, were from Sigma (St Louis, MO), H-Phe-Pro-Arg chloromethyl ketone (PPACK) was from Calbiochem (La Jolla, CA), and Fluo-3 and calcein acetoxymethyl esters were from Molecular Probes (Leiden, The Netherlands). Annexin V (Apoptest) labeled with Oregon Green 488 (OG488) was obtained from Nexins Research (Hoeven, The Netherlands). AR-C69931MX, an antagonist of the P2Y 12 receptor, was from Astra-Zeneca (Charnwood, United Kingdom). Acetylsalicylic acid (ASA) was from Lorex Synthelabo (Maarssen, The Netherlands), and low-molecular-weight heparin (Fragmin) was from Pharmacia N.V. (Puurs, Belgium). The GFOGER-GPP and CRP peptides were synthesized as described ${ }^{20,23}$. ScFv antibodies $10 \mathrm{~B} 12$ and $1 \mathrm{C} 3^{19}$ and $\mathrm{mAb} 12 \mathrm{G} 1$ against GPIb $\alpha$ has been previously described ${ }^{24,25}: 12 \mathrm{G} 1$ inhibits platelet deposition to type 1 72 
collagen by $90 \%$ at $5 \mu \mathrm{g} / \mathrm{mL}$, ristocetin-induced platelet aggregation with an $\mathrm{IC}_{50}$ of 1.25 $\mu \mathrm{g} / \mathrm{mL}$, ristocetin-induced VWF binding to GPIb by $35 \%{ }^{24}$, and $35 \%$ of thrombin generation under intermediate shear ${ }^{25}$. $\mathrm{Fab}_{2}$ fragments were generated by standard methodology. The mAb 6F1 against $\alpha 2$ was a generous gift from Prof B. Coller (Mount Sinai Hospital, New York, NY) ${ }^{21}$. The anti- $\beta 1$ mAb 4B4 was from Beckman Coulter (High Wycombe, United Kingdom). Saratin was kindly provided by $\operatorname{Dr}$ M. Hoylaerts (KU, Leuven, Belgium) ${ }^{26}$.

\section{Blood collection}

Blood from 9 healthy volunteers was collected in $40 \mu \mathrm{M}$ PPACK in 0.1 vol saline, supplemented hourly with $10 \mu \mathrm{M}$ PPACK. Donors had not taken medication for 2 weeks. Platelet counts were determined with a Coulter counter (Coulter Electronics, Hialeah, FL). Donors were genotyped for receptor polymorphisms: GPVI (a/b), $\alpha 2 \beta 1$ ( $\alpha 2$ $807 \mathrm{C} / \mathrm{T}$ ), and GPIb (5-C/T) using TaqMan at the National Blood Service (Cambridge, United Kingdom). All donors expressed high GPVI levels (7 aa, $2 \mathrm{ab})^{18}$. Five donors were CT for C807T $\alpha 2$ polymorphism, implying an average density of $\alpha 2 \beta 1$ on the platelet surface. Three donors were low expressors of $\alpha 2 \beta 1$ (CC), and one was a high expressor (TT). In this small population, C807T $\alpha 2$ polymorphism had no apparent effect on any of the platelet responses. Two donors were CT for GPIb C5T.

\section{Static platelet adhesion}

Static platelet adhesion to CRP and fibrillar collagen was performed exactly as previously described ${ }^{27}$, using cation-free conditions to examine the adhesive role of GPVI in the absence of $\alpha 2 \beta 1$.

\section{Intracellular $\mathrm{Ca}^{2+}$ and thrombus volume measurements}

Acid citrate dextrose-platelet-rich plasma (ACD-PRP) was incubated with $7 \mu \mathrm{M}$ Fluo-3 acetoxymethyl ester or calcein for 30 minutes at $37^{\circ} \mathrm{C}$. Platelets were centrifuged with 0.1 vol ACD, washed once with HEPES ( $N$-2-hydroxyethylpiperazine- $N$ '-2ethanesulfonic acid) buffer containing $10 \mathrm{mM}$ HEPES, $136 \mathrm{mM} \mathrm{NaCl}, 2.7 \mathrm{mM} \mathrm{KCl}, 2 \mathrm{mM}$ $\mathrm{MgCl}_{2}, 0.1 \%$ glucose, $0.1 \%$ bovine serum albumin (BSA), $\mathrm{pH} 6.6$, centrifuged again with 0.1 vol ACD, and suspended in the original volume of PRP with HEPES buffer, $\mathrm{pH} 7.45$. PPACK-anticoagulated blood was spiked with Fluo-3-labeled platelets at $10 \%$ of the original platelet count and with $30 \mu \mathrm{M}$ PPACK. 
In control perfusions over collagen, $30 \%$ of $7 \mu \mathrm{M}$ calcein-prelabeled autologous platelets were added. In real-time, Z-stacks of $x-y$ scans were taken during the perfusion (box volume of $171.8 \times 171.8 \times 50 \mu \mathrm{m}$ ) at a 2-photon excitation wavelength of $800 \mathrm{~nm}$ and an emission of 485 to $515 \mathrm{~nm}$ ( $8 \%$ of full power) using a Radiance 2000 multiphoton laser scanning fluorescence microscope system (BioRad, Hemel Hempstead, United Kingdom), equipped with a pulsed sub-picosecond Tsunami Ti:sapphire laser (SpectraPhysics, Mountain View, CA). Two-photon images were analyzed with Laserpix software (Bio-Rad).

\section{Flow experiments and image recording}

Whole blood perfusion experiments were performed essentially as described for mouse blood ${ }^{28}$. Briefly, glass coverslips were coated with collagen fibers $\left(12.5 \mu \mathrm{g} / \mathrm{cm}^{2}\right)$ and blocked with HEPES buffer, $\mathrm{pH} 7.45$, containing $1 \% \mathrm{BSA}$ and $1 \%$ glucose. The blood was placed in a syringe and perfused over the coverslip through a transparent $50 \mu \mathrm{m}$ deep chamber using a pulse-free pump ${ }^{29}$, at a shear rate of $1000 \mathrm{~s}^{-1}$ for 4 minutes. Blood was incubated for 15 minutes before perfusion with various concentrations of scFv 10B12 or $1 \mathrm{C} 3,10$ to $20 \mu \mathrm{g} / \mathrm{mL} 6 \mathrm{~F} 1,500 \mu \mathrm{g} / \mathrm{mL}$ GFOGER-GPP, $10 \mu \mathrm{g} / \mathrm{mL}$ 4B4, $20 \mu \mathrm{g} / \mathrm{mL}$ Fab $_{2}$ fragment 12G1, ASA $(100 \mu \mathrm{M})$, MRS2179 $(40 \mu \mathrm{M})$, and AR-C69931MX $(20 \mu \mathrm{M})$ or $1 \mathrm{U} / \mathrm{mL}$ apyrase, as described. Where indicated, autologous Fluo-3-labeled platelets were added to the blood before antagonists.

Microscopic phase-contrast and fluorescent images from Fluo-3-labeled platelets were recorded in real-time using a Visitech digital imaging system (Sunderland, United Kingdom) equipped with 2 intensified, charge-coupled device (CCD) cameras ${ }^{30}$. After perfusion, flow chambers were rinsed at the same flow rate for 4 minutes with HEPES buffer, pH 7.45, supplemented with $1 \mathrm{U} / \mathrm{mL}$ heparin and $2 \mathrm{mM} \mathrm{CaCl} 2$. Phasecontrast and fluorescent images were collected with a 40x UV-transparent objective and $15 x$ to $20 x$ image magnification. Exposure of PS was detected after incubation of the slide with $100 \mu \mathrm{L} \mathrm{HEPES} / \mathrm{CaCl}_{2}$ buffer, $\mathrm{pH} 7.45$, containing OG488-labeled annexin V (1 $\mu \mathrm{g} / \mathrm{mL}$ ) for 5 minutes. Antibodies and antagonists were also added to the rinsing buffer and the annexin $\mathrm{V}$ incubation.

\section{Image analysis}

Surface coverage from phase-contrast images was analyzed using Image-Pro (Silver Spring, MD) software version 4.1, and it was analyzed from platelets stained with OG488-annexin V using Quanticell software (Visitech). Distribution of aggregate sizes in 
phase-contrast images was measured using Leica QWin image analysis software (Leica Imaging Systems, Cambridge, United Kingdom). Changes in Fluo-3 fluorescence from individual platelets were converted to $\left[\mathrm{Ca}^{2+}\right]_{i}$ as described ${ }^{31}$. To provide a measure of the proportion of procoagulant cells independent of platelet deposition, the ratio of annexin $\mathrm{V}$-binding surface coverage to phase-contrast surface coverage was calculated and was termed procoagulant index $(\mathrm{Pi})$. Although the procoagulant area was overestimated through fluorescent glare in the optics, Pi provided a means of distinguishing the effects of treatments on procoagulant expression from those on platelet deposition.

\section{Experimental design and statistics}

Each experimental condition was tested on at least 3 occasions using blood from different donors, and each donor provided blood for at least 10 perfusion experiments. Control conditions were included for each blood sample, together with other permutations of conditions. For each perfusion surface, images from 9 random microscopic fields were collected, and the average percentage area covered by adherent platelets was measured either by phase-contrast or by OG-labeled annexin $V$ fluorescence. Phase-contrast, fluorescent surface coverage (mean $\pm \mathrm{SE}$ ) and Pi were compared among all experimental groups using analysis of variance (ANOVA), with Newman-Keuls or Dunnett posttesting. Data derived from the same donors were compared by paired sample $t$ tests or ANOVA. The effect of ADP blockade under different conditions was tested by 2-way ANOVA. Image analysis provided estimates (area and roundness of separate features, such as platelets and aggregates) of thrombus size and shape. Features were segmented digitally and measured with minimal operator intervention. From an average of 9 images, using 3 different donors, at least 200 different features were measured for each treatment, the effects of which were determined by $x^{2}$ analysis. Data are plotted as frequency distributions with mean values per field $( \pm$ SE). Prism (GraphPad Software, San Diego, CA) was used throughout for multiple comparisons and linear regression. 


\section{Results}

\section{Blocking of GPVI abolishes aggregate formation, $\mathrm{Ca}^{2+}$ signaling, and PS exposure without eradicating primary platelet adhesion}

PPACK-anticoagulated whole blood was perfused at high shear rate $\left(1000 \mathrm{~s}^{-1}\right)$ over a surface covered with native collagen type I fibrils. Phase-contrast and fluorescence microscopic images were captured to monitor 2 independent parameters of thrombus formation measured as the surface coverage of deposited platelets and of procoagulant, PS-exposing platelets that stained with OG488-conjugated annexin V. In control perfusions, platelets rapidly adhered to the collagen fibers, forming aggregates that later coalesced (Figure 1A). The deposition of platelets measured by surface coverage was linear in time, indicating regular and continuous scavenging of platelets (Figure 2A). To confirm that the measuring surface area represents a linear progression of thrombus build-up, the thrombus volume was measured by using calcein-labeled platelets from the same donor and real-time scanning of the 2-photon fluorescence signal, which even at more than $50 \mu \mathrm{m}$ penetration was typically not distorted by the

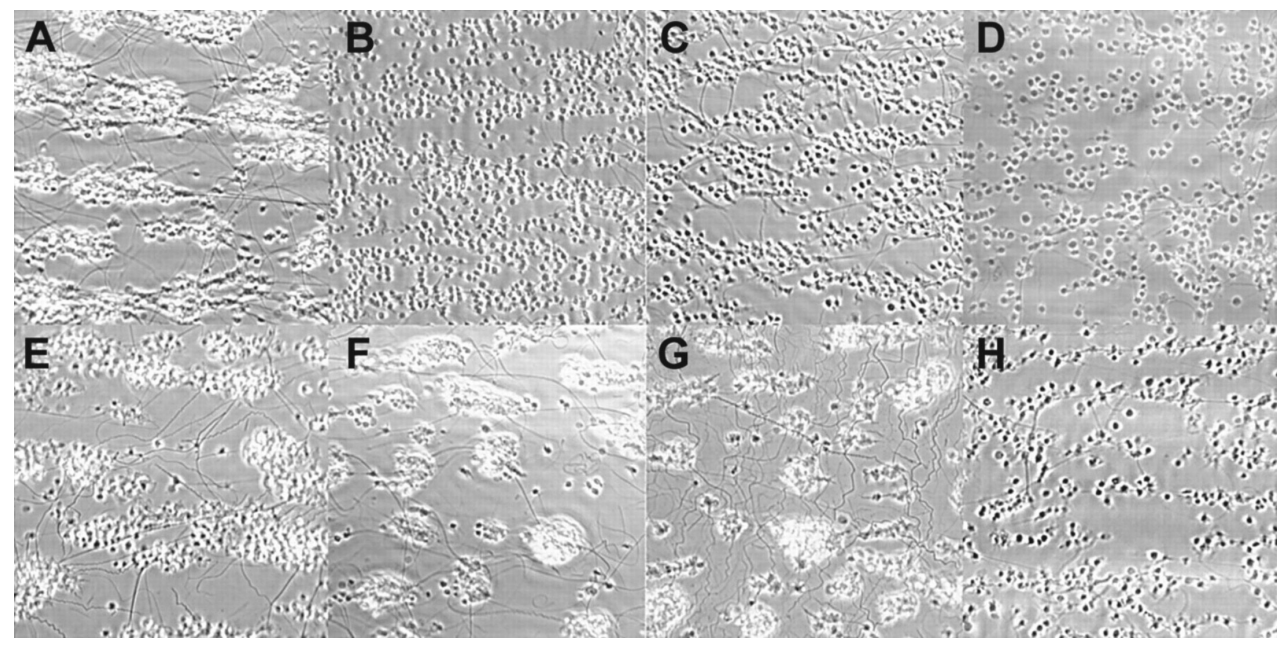

Figure 1 Effects of inhibitory antibodies and receptor antagonists on thrombus formation. Images $(120 \times 120 \mu \mathrm{m})$ were recorded using a phase-contrast microscope after the perfusion of PPACK-anticoagulated whole blood over a collagen-coated surface for 4 minutes at a shear rate of $1000 \mathrm{~s}^{-1}$ Antibodies or inhibitors were added 15 minutes before perfusion. (A) Control. (B-D) 10B12 at 50,100 , or $300 \mu \mathrm{g} / \mathrm{mL}$, respectively. (E) scFv $1 \mathrm{C} 3$ at $100 \mu \mathrm{g} / \mathrm{mL}$. (F) $6 \mathrm{~F} 1$ at $20 \mu \mathrm{g} / \mathrm{mL}$. (G) GFOGERGPP at $500 \mu \mathrm{g} / \mathrm{mL}$. (H) ADP-receptor and TxA $\mathrm{T}_{2}$ blockade by $40 \mu \mathrm{M}$ MRS2179, $20 \mu \mathrm{M}$ AR-C69931MX, $1 \mathrm{U} / \mathrm{mL}$ apyrase, and $100 \mu \mathrm{M}$ ASA. Images shown are representative of 3 to 9 independent experiments. Collagen fibers are visible in some of the panels. Original magnification, $x 60$. 
flowing blood. Again, thrombus volume increased linearly in time (Figure 2B). No differences in platelet deposition were observed within the donor population, relating to genetic polymorphisms of GPVI, $\alpha 2 \beta 1$, or GPIb $\alpha$. By the 4 -minute end point, $17.9 \% \pm$ $0.8 \%$ of the surface was covered by platelets. Most platelets were deposited as interconnected islets originating from individual aggregates. The mean feature size was $176 \pm 16 \mu^{2}$, an area corresponding to approximately 40 platelets. Single platelets made up $22 \%$ of features, whereas $10 \%$ were large aggregates corresponding to 130 platelets or more (Figure 3A). Large numbers of blebbing platelets were observed in direct contact with collagen fibers, and staining with OG488-annexin $\mathrm{V}$ revealed $8.3 \% \pm$ $0.7 \%$ coverage of PS-exposing platelets. To provide a measure of procoagulant platelets independent of the total number of adherent cells, the ratio of the 2 surface parameters was expressed as $\mathrm{Pi}$, giving a value of $0.43 \pm 0.03$. Thrombin generation was absent during and after perfusion because no fibrin or D-dimer was observed. Including Fragmin $(0.5 \mathrm{U} / \mathrm{mL})$ as an additional anticoagulant did not change platelet deposition or annexin $\mathrm{V}$ binding from PPACK-only controls (data not shown).

Blocking GPVI by 10B12 inhibited CRP- and collagen-induced platelet aggregation in vitro ${ }^{19}$. Static platelet adhesion to CRP was abolished at $5 \mu \mathrm{g} / \mathrm{mL}$ and decreased by $80 \% \pm 4 \%(n=4)$ to collagen fibers at $25 \mu \mathrm{g} / \mathrm{mL}$. However, under flow, $a$ concentration curve for 10B12 (Figure 4) showed that, up to $300 \mu \mathrm{g} / \mathrm{mL}$, surface coverage with platelets did not significantly decrease $\left(r^{2}=0.22 ; P=.42\right)$, though,

A

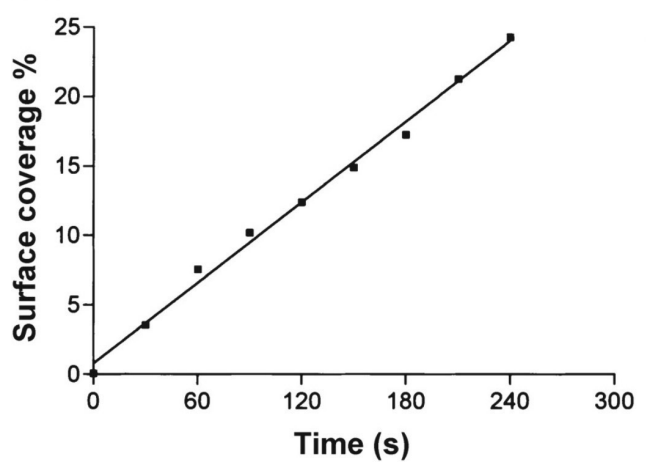

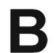

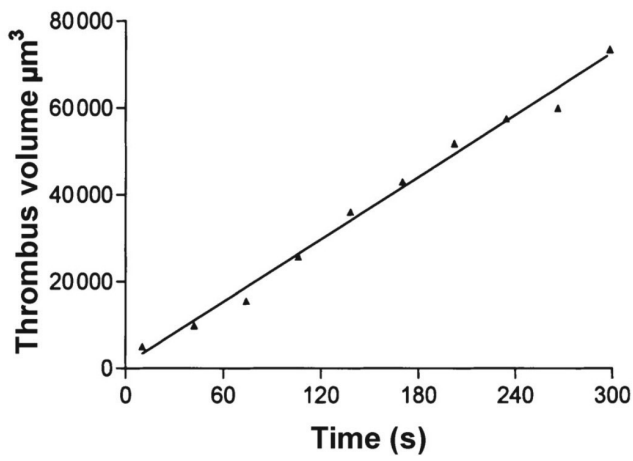

Figure 2 Thrombus formation measured by surface area coverage or thrombus volume is linear in time. (A) Phase-contrast video images captured during the flow of PPACK-anticoagulated whole blood over collagen at $1000 \mathrm{~s}^{-1}$ were analyzed for platelet surface area coverage, which was plotted against perfusion time. Linear regression showed $R^{2}=0.97-0.99(n=3)$. (B) Thrombus volume was measured using blood supplemented with $30 \%$ of calcein-labeled autologous platelets. Z-stacks of $x-y$ scans were measured in real-time by 2 -photon laser scanning microscopy. Fluorescence image stacks were reconstructed 3 dimensionally and analyzed. Plots of thrombus volume compared with time were linear up to $300 \mathrm{~s}\left(R^{2}=0.99\right)$. Representative plots are shown in panels $\mathrm{A}$ and $\mathrm{B}$. 
dramatically, platelet aggregates were absent (Figure 1B-D).

Biosensor data indicated that at $300 \mu \mathrm{g} / \mathrm{mL} 10 \mathrm{~B} 12$, occupancy of recombinant GPVI had reached more than $97 \%$ (data not shown). The predominance of single platelets with increasing 10B12 concentrations, obvious to the eye, was quantified by image analysis as almost complete elimination of larger aggregates $(P<.0001)$ at 50 $\mu \mathrm{g} / \mathrm{mL} 10 \mathrm{~B} 12$, and the mean area was reduced to $37 \pm 2 \mu \mathrm{m}^{2}$ from $176 \pm 16 \mu \mathrm{m}^{2}(P<$ .001) (Figure 3B). In contrast to platelet adhesion, surface coverage of PS-exposing platelets decreased progressively with the $10 \mathrm{~B} 12$ concentration with an $\mathrm{IC}_{50}$ value of 23 $\mu \mathrm{g} / \mathrm{mL}(\mathrm{r} 2=0.94 ; \mathrm{P}<.01)$ (Figure 4 ), and blebbing platelets were no longer visible. At the highest concentration of 10B12 tested, the Pi was reduced to $0.02 \pm 0.005(P<.001)$, indicating strong blockade of GPVI function.

ScFvs $1 \mathrm{C} 3$ and 10B12 recognizes distinct epitopes, and 1C3 is incapable of blocking static platelet adhesion to CRP or collagen-induced platelet aggregation ${ }^{19}$. As expected, $1 \mathrm{C} 3(100 \mu \mathrm{g} / \mathrm{mL})$ did not alter either the surface coverage (Figure 1E) or the size and morphology (Figure $3 \mathrm{C}$ ) of the formed thrombi. However, 1C3 halved the PS expressing surface coverage (Figure 4), suggesting that the 1C3-binding site is relevant for GPVI function, possibly by influencing receptor clustering or dimerization. The $\mathrm{Pi}$ obtained with $1 \mathrm{C} 3$ was reduced to $0.24 \pm 0.07(P<.05$, relative to control), a significantly higher Pi than with $100 \mu \mathrm{g} / \mathrm{mL}$ 10B12 $(P<.001)$. Coinhibition with $10 \mathrm{~B} 12$ and $1 \mathrm{C} 3 \mathrm{did}$ not change surface coverage from that of 10B12 alone (data not shown).

To study the dynamics of platelet activation, $\mathrm{Ca}^{2+}$ signal generation was measured in real-time under flow from single, Fluo-3-labeled platelets coming in contact with collagen. Control platelets exhibited a strong $\mathrm{Ca}^{2+}$ response, sometimes preceded by an initial $\mathrm{Ca}^{2+}$ spike (Figure $\left.5 \mathrm{~A}\right)$. A submaximal dose $(50 \mu \mathrm{g} / \mathrm{mL})$ of $10 \mathrm{~B} 12$ decreased the $\mathrm{Ca}^{2+}$ signal amplitude (Figure 5B). Although blocking GPVI did not abolish primary adhesion, the increased translocation of platelets across the collagen surface was observed during $\mathrm{Ca}^{2+}$ measurements. Increasing the $10 \mathrm{~B} 12$ concentration to $300 \mu \mathrm{g} / \mathrm{mL}$ reduced the $\mathrm{Ca}^{2+}$ signal slightly further (Figure $5 \mathrm{C}$ ). No difference from controls was observed in the averaged $\mathrm{Ca}^{2+}$ response with $1 \mathrm{C} 3(100 \mu \mathrm{g} / \mathrm{mL})$, though $\mathrm{Ca}^{2+-}$ spiking occurred in individual platelets (Figure 5D). Together, these data indicate that blocking of GPVI with 10B12 potently suppressed collagen-dependent platelet activation pathways without eradicating primary adhesion. 
A

\section{Control}

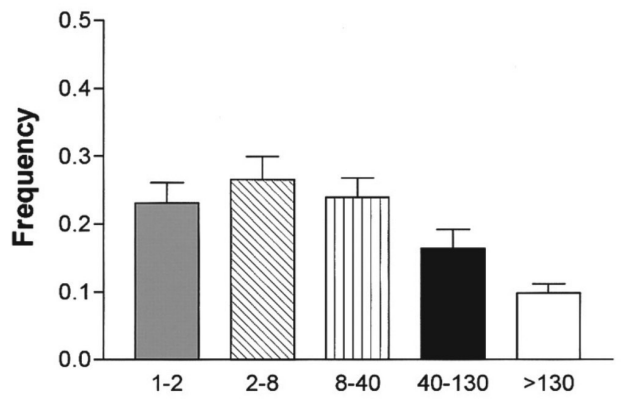

C

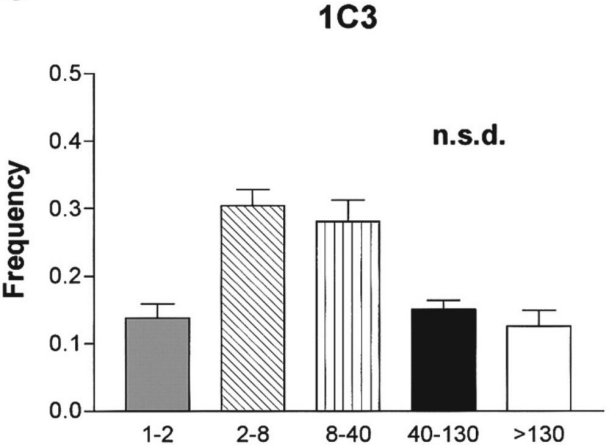

E

6F1

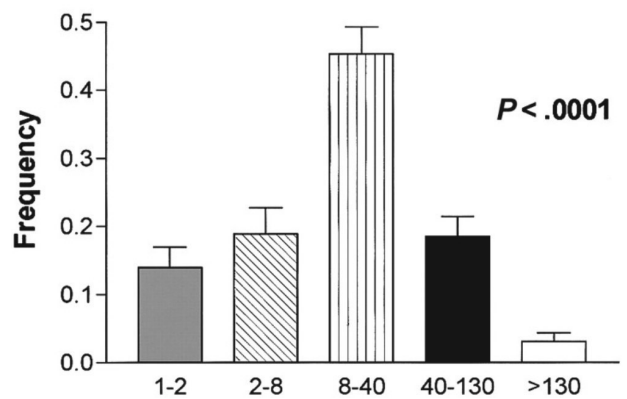

B

10B12

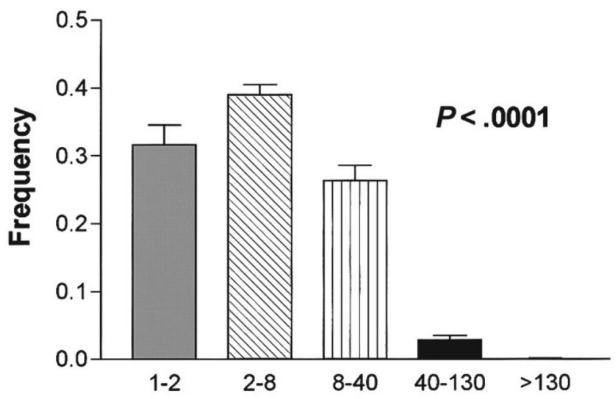

D

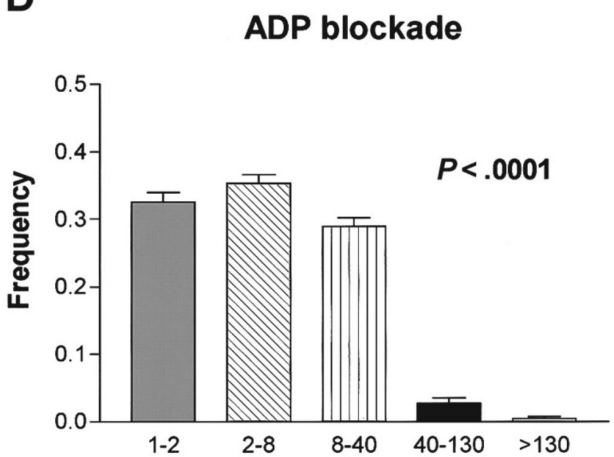

F

\section{GFOGER}

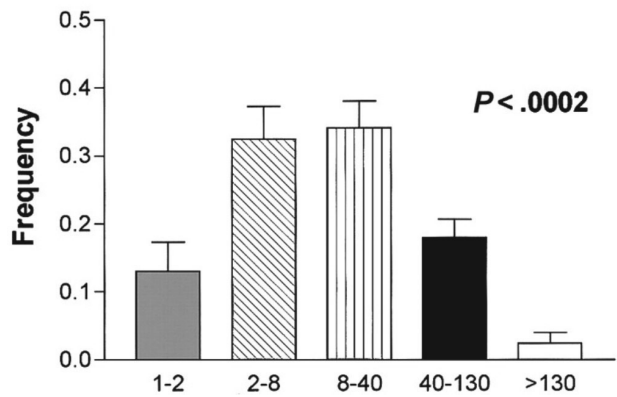

Figure 3 Effects of inhibitory antibodies and receptor antagonists on size distribution of platelet aggregates during thrombus formation. Histograms were obtained by image analysis of phase-contrast micrographs obtained from perfused collagen surfaces. Estimated numbers of platelets per feature

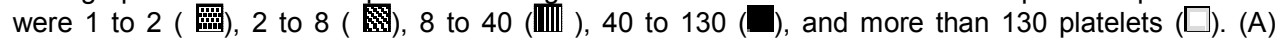
Control. (B) $10 B 12$ at $50 \mu \mathrm{g} / \mathrm{mL}$. (C) $1 \mathrm{C} 3$ at $100 \mu \mathrm{g} / \mathrm{mL}$. (D) ADP receptor and $\mathrm{TxA}_{2}$ blockade. (E) $6 \mathrm{~F} 1$ at $20 \mu \mathrm{g} / \mathrm{mL}$. (F) GFOGER-GPP at $500 \mu \mathrm{g} / \mathrm{mL}$. Data (A-F) are mean \pm SE from 3 donors. Statistical significance compared with the control was established from contingency tables ( $X^{2}$ analysis). 


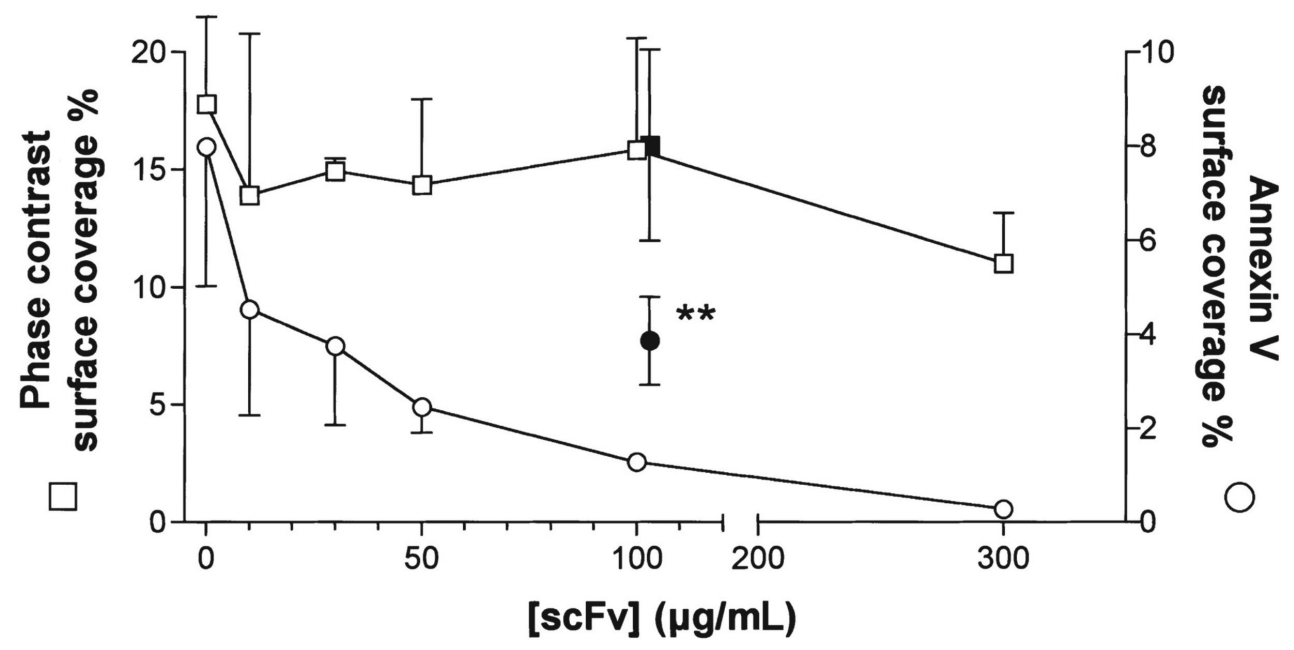

Figure 4 Inhibition of GPVI causes dose-dependent reduction in platelet PS exposure but not in total surface coverage. Blood was treated with $10 \mathrm{~B} 12$ at $10-300 \mu \mathrm{g} / \mathrm{mL}$ (white symbols) or $1 \mathrm{C} 3$ at $100 \mu \mathrm{g} / \mathrm{mL}$ (black symbols). Total surface coverage of platelets (squares) and surface coverage of OG488-labeled annexin $\mathrm{V}$ binding platelets (circles) were measured after 4 minutes of perfusion. Data represent mean \pm SE from 3 to 17 experiments performed on the blood of 3 donors. ${ }^{* *}$ Significant difference from 10B12 treatment $(P<.001)$ and from control $(P<.05)$.

Blocking of GPIb or $\alpha 2 \beta 1$ reduces primary adhesion and aggregate formation, but blocking only $\alpha 2 \beta 1$ inhibits PS exposure

High levels of VWF and high $\alpha 2 \beta 1$ density have been correlated with increased platelet deposition on collagen ${ }^{32,33}$, whereas patients with VWF concomitant with low $\alpha 2 \beta 1$ expression bleed more than patients with either condition alone ${ }^{34}$. The essential nature of GPIb and $\alpha 2 \beta 1$ in human platelet deposition on collagen under flow has been emphasized ${ }^{23,32,35}$, though other studies failed to detect consistent involvement of $\alpha 2 \beta 1^{4}$. This prompted us to revisit the topic in the context of molecular interplay with GPVI using the following antagonists: $12 \mathrm{G} 1 \mathrm{Fab}_{2}$ fragment, recognizing amino acids 1 to 59 of GPIb $\alpha$, hinders platelet adhesion to collagen by inhibiting VWF-GPIb interaction at highshear $^{24,25}$; anti- $\alpha 2 \mathrm{mAb} 6 \mathrm{~F} 1$, whose epitope within the I-domain is separate from the MIDAS motif and lies between residues 173 and $259^{36}$; and the GFOGER-GPP peptide, which inhibits collagen binding through the $\alpha 2$ MIDAS $^{37}$. 


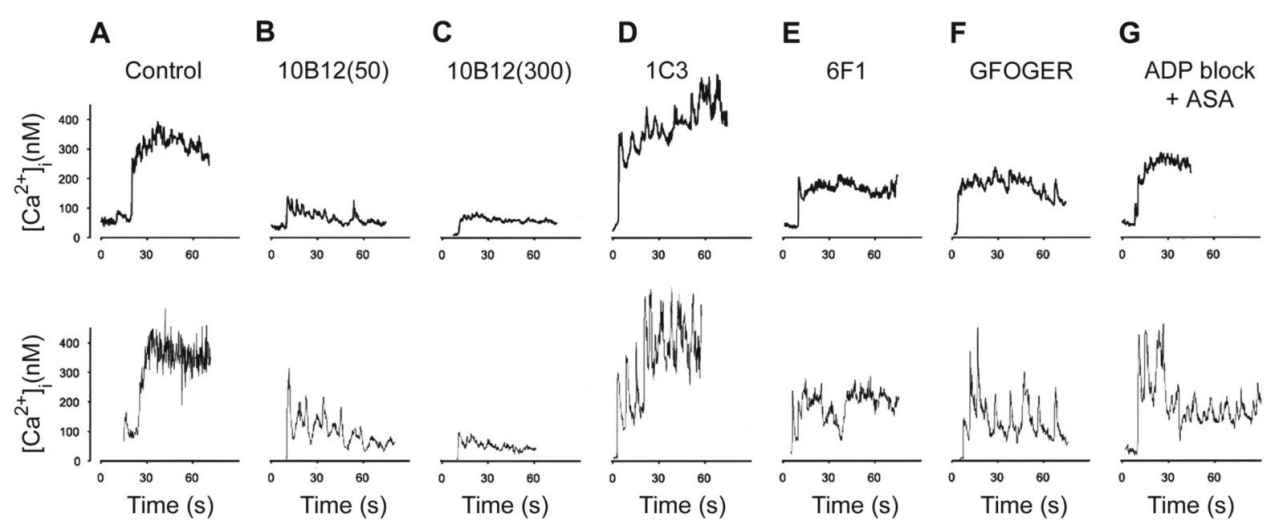

Figure 5 Effects of inhibitory antibodies and receptor antagonists on $\mathrm{Ca}^{2+}$ responses of platelets interacting with collagen under flow. Blood was spiked with $10 \%$ Fluo-3-loaded autologous platelets, incubated with antagonists, and perfused over collagen, as indicated for Figure 1. Changes in $\left[\mathrm{Ca}^{2+}\right]_{\mathrm{i}}$ were recorded during perfusion in single collagen-adherent platelets. Traces above are averaged curves from 15 to 25 platelets ( 3 donors); traces below are representative curves from single platelets. (A) Control. (B) $10 \mathrm{~B} 12$ at $50 \mu \mathrm{g} / \mathrm{mL}$. (C) $10 \mathrm{~B} 12$ at $300 \mu \mathrm{g} / \mathrm{mL}$. (D) $1 \mathrm{C} 3$ at $100 \mu \mathrm{g} / \mathrm{mL}$. (E) $6 \mathrm{~F} 1$ at 20 $\mu \mathrm{g} / \mathrm{mL}$. (F) GFOGER-GPP at $500 \mu \mathrm{g} / \mathrm{mL}$. (G) ADP-receptor and TxA2 blockade, as in Figure 1.

The importance of GPIb in primary adhesion ${ }^{4}$ was reconfirmed under the shear rate conditions used here. Using $12 \mathrm{G} 1 \mathrm{Fab}_{2}$ at a maximally effective dose of $40 \mu \mathrm{g} / \mathrm{mL}$, the overall surface coverage was reduced by $50 \% \pm 14 \%$ (Figure 6 ), which confirms that at (arterial) shear rates of approximately $1000 \mathrm{~s}^{-1}$, platelet adhesion to collagen is only partially dependent on VWF-GPIb interaction ${ }^{38,39}$. Although in 2 donors surface coverage was strongly inhibited (63\% and $67 \%), 2$ gave a weaker reduction in thrombus formation (38\% and $45 \%$ ), but the differential response did not correlate with $-5 \mathrm{C} / \mathrm{T}$ polymorphism. For all donors, blocking of GPIb strongly influenced platelet tethering. GPIbe-blocked platelets moved swiftly over the collagen surface, but, once adherent, they became fully activated. Adding $12 \mathrm{G} 1 \mathrm{Fab}_{2}$ reduced the PS exposure of platelets, but this simply reflected the decrease in surface coverage (Figure 6A) without a change in Pi. Like $12 \mathrm{G} 1$, saratin, which blocks the binding of VWF to collagen ${ }^{40}$, caused only a partial reduction of platelet surface coverage $(68 \% \pm 14.5 \%)$ and annexin $V$ staining $(27 \% \pm$ $0.3 \% ; n=2)$. 


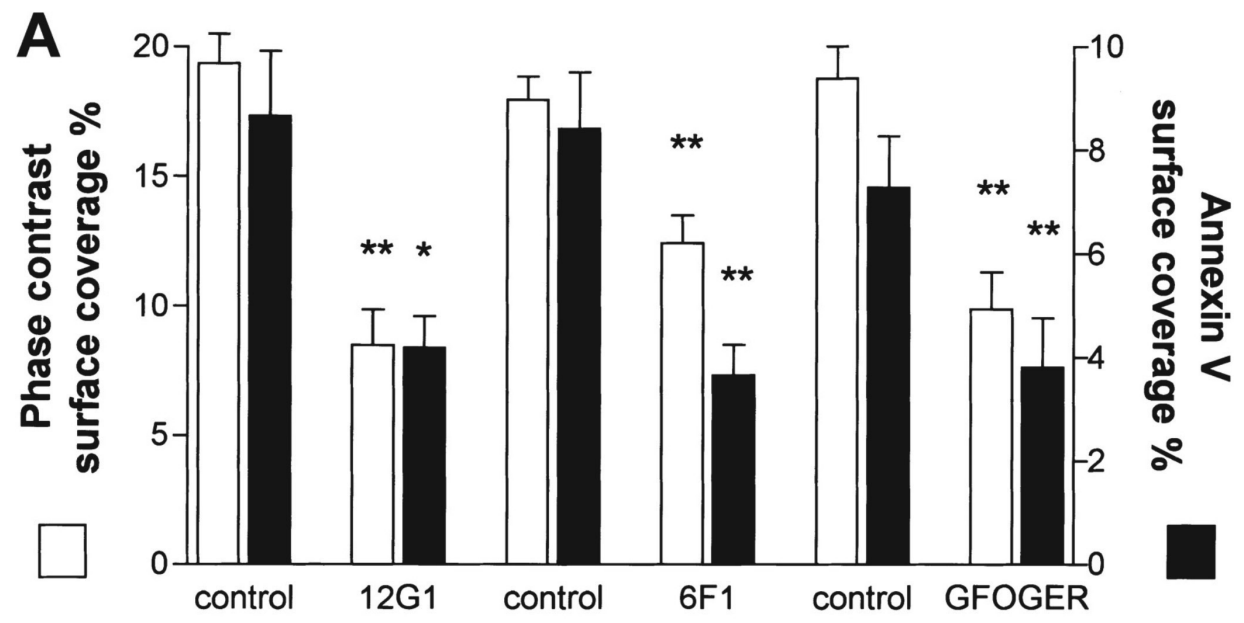

B

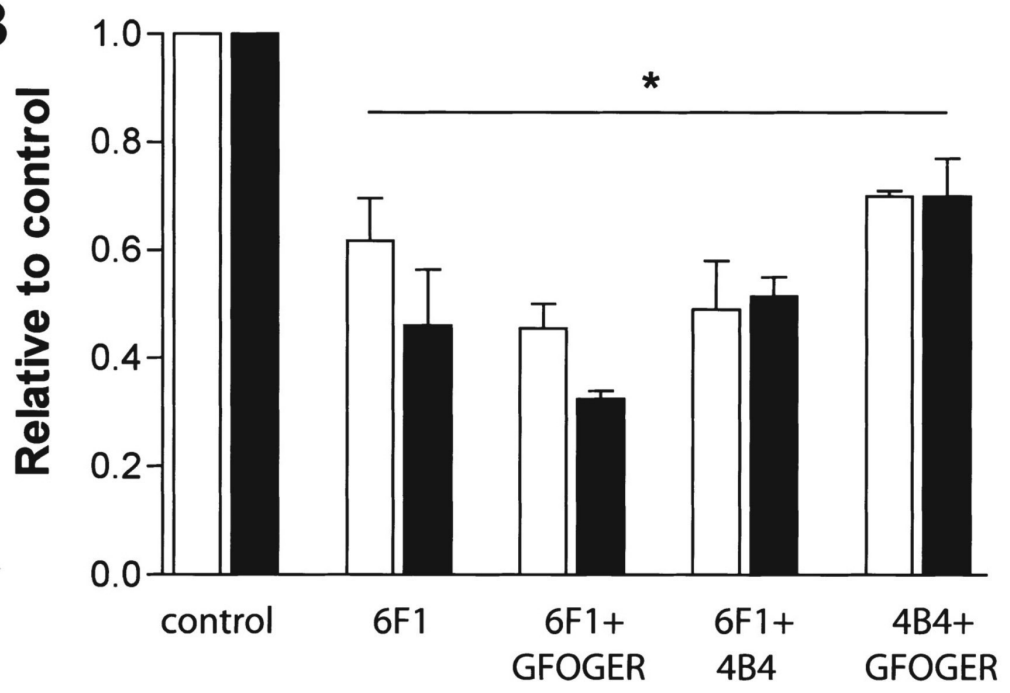

Figure 6 Blocking of GPIb $\alpha$ or $\alpha 2 \beta 1$ partially reduces surface coverage on collagen, but blocking only of $\alpha 2 \beta 1$ affects PS exposure. (A) Blood was treated with $12 \mathrm{G} 1 \mathrm{Fab}_{2}$ at $40 \mu \mathrm{g} / \mathrm{mL}$ and $6 \mathrm{~F} 1$ at $20 \mu \mathrm{g} / \mathrm{mL}$ or GFOGER-GPP at $500 \mu \mathrm{g} / \mathrm{mL}$ and was perfused over collagen, as described for Figure 1. Data present surface coverage of platelet deposition or OG488-labeled annexin $\mathrm{V}$ binding (mean $\pm \mathrm{SE}$, from 4-6 experiments). ${ }^{* *} P<.01$, and ${ }^{*} P<.05$ compared with matched controls. (B) Blood was treated with combinations of anti- $\alpha 2$ 6F1 or GFOGER and anti- $\beta 1$ 4B4 $(10 \mu \mathrm{g} / \mathrm{mL})$. Data (mean $\pm \mathrm{SE}$ ) present the proportion of phase- or annexin $V$-positive surface coverage relative to matched controls. All combinations significantly inhibited platelet responses compared with respective controls $\left({ }^{*} P<.05 ; n=2\right)$ but not with each other.

Inhibition of $\alpha 2 \beta 1$ integrin by mAb 6F1, at a saturating concentration of 10 to 20 $\mu \mathrm{g} / \mathrm{mL}$, reduced surface coverage in all donors by approximately $30 \% \pm 11 \%$ (Figure $6 \mathrm{~A}$ ). The tethering platelets reluctantly anchored to collagen fibers and, on arrest, formed only small, dense aggregates (Figure $1 \mathrm{~F}$ ). Image analysis indicated a smaller mean 
aggregate size of $117 \pm 9 \mu \mathrm{m}^{2}$ with a shift toward round structures $(\mathrm{P}<.001)$. Aggregate sizes showed a kurtotic distribution $(P<.0001)$, with a $50 \%$ increase in mid-sized features (Figure 3E). Similarly, GFOGER-GPP significantly reduced surface coverage by approximately $45 \% \pm 13 \%$ at a maximally effective dose of $500 \mu \mathrm{g} / \mathrm{mL}$ (Figure $6 \mathrm{~A}$ ). Changes in aggregate morphology closely matched those obtained with $6 \mathrm{~F} 1 \mathrm{mAb}$-that is, aggregates appeared as round structures (Figure 1G), of smaller, average size (Figure 3F).

Inhibition of $\alpha 2 \beta 1$ with either mAb 6F1 or GFOGER-GPP had a small but significant effect $(P<.01)$ on the exposure of PS (Figure 6A). The Pi was reduced from $0.43 \pm 0.03$ to $0.30 \pm 0.04(P<.05)$ and $0.37 \pm 0.08$ (not significant), respectively. To ensure maximal blocking of $\alpha 2 \beta 1$, we tested combinations of antagonists binding different epitopes. The most effective of 3 anti- $\beta 1$ mAbs tested, $4 \mathrm{~B} 4$-against the activatory hinge region 207 to 21822-caused less inhibition than GFOGER or 6F1 (data not shown). Slight further inhibition was seen when 6F1 was combined with 4B4 or GFOGER, but these reductions were not significant (Figure 6B). A role of $\alpha 2 \beta 1$ in platelet signaling was also supported by the decreased $\mathrm{Ca}^{2+}$ response of the collagenadherent platelets. With both 6F1 (Figure 5E) and GFOGER-GPP (Figure 5F), the average $\mathrm{Ca}^{2+}$ response was decreased, and the responses of most single platelets showed transient or spiking increases in intracellular $\mathrm{Ca}^{2+}$. These findings reconfirm the contribution of GPIb and $\alpha 2 \beta 1$ to collagen-induced thrombus formation but underscore their different roles. Blocking GPIb interfered with platelet tethering and initial anchorage and dispersed aggregates with little effect on PS exposure, but $\alpha 2 \beta 1$ blockade reduced primary adhesion (partially by prolonging firm anchorage) and restricted thrombus size, platelet activation, $\mathrm{Ca}^{2+}$ signaling, and PS exposure.

\section{Combined inhibition of GPVI with either GPIb or $\alpha 2 \beta 1$ integrin completely abolishes thrombus formation}

Coinhibition of GPVI with 10B12 $(100 \mu \mathrm{g} / \mathrm{mL})$ and of GPIb with 12G1 Fab 2 (40 $\mu \mathrm{g} / \mathrm{mL}$ ) resulted in almost complete abolition of platelet adhesion, with remaining single platelets covering not more than $2 \%$ of the surface; PS-exposing platelets were hardly detected (Figure 7A-B). Similarly, coinhibition of GPVI and $\alpha 2 \beta 1$ with $6 \mathrm{~F} 1(20 \mu \mathrm{g} / \mathrm{mL})$ or GFOGER-GPP $(500 \mu \mathrm{g} / \mathrm{mL})$ completely inhibited stable platelet adhesion and all subsequent activation events, eradicating thrombus formation (Figure 7A-B). Calcium responses, measured in platelets adhering in the presence of $6 \mathrm{~F} 1$ and 10B12, resembled the responses measured in the presence of 10B12 alone (data not shown). 


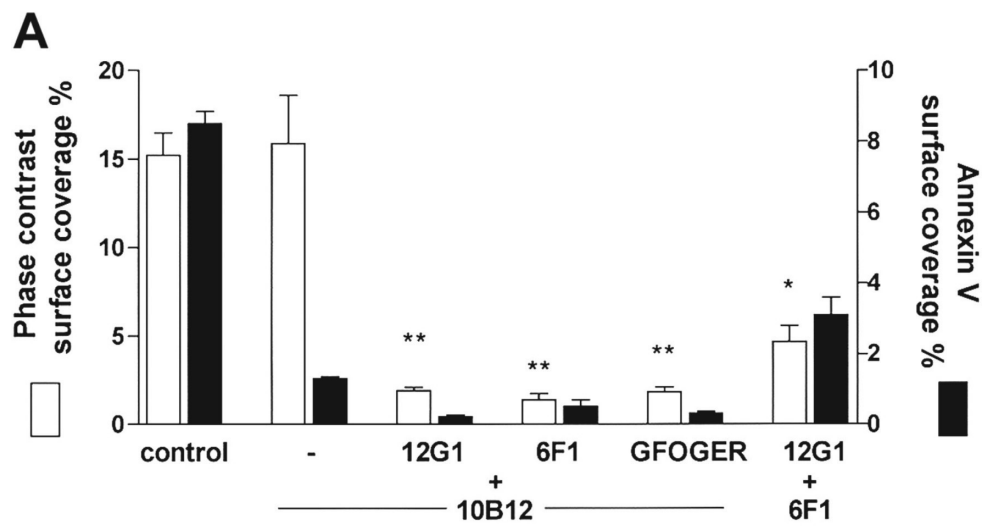

B
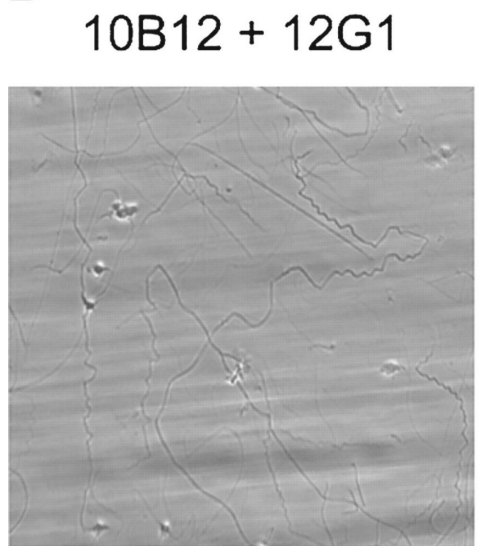

\section{$10 \mathrm{~B} 12+6 \mathrm{~F} 1$}

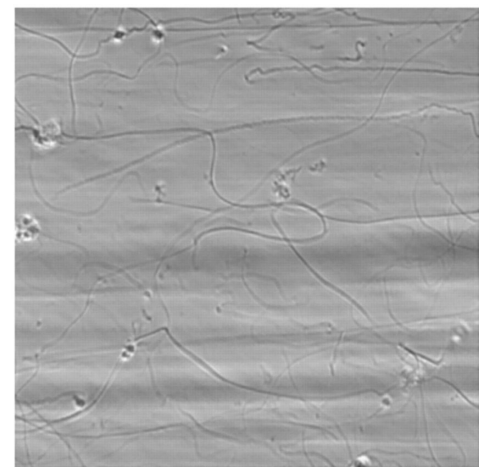

Figure 7 Combined inhibition of GPVI with GPIb or $\alpha 2 \beta 1$ abolishes collagen-induced thrombus formation. Blood was treated with the indicated combination of antagonists before perfusion over collagen: $10 \mathrm{~B} 12$ at $100 \mu \mathrm{g} / \mathrm{mL}$ and $6 \mathrm{~F} 1$ at 10 to $20 \mu \mathrm{g} / \mathrm{mL}$, GFOGER-GPP at 500 $\mu \mathrm{g} / \mathrm{mL}$ or $12 \mathrm{G}_{1} \mathrm{Fab}_{2}$ at $40 \mu \mathrm{g} / \mathrm{mL}$ perfused over collagen as in Figure 1. (A) Surface coverage of platelet deposition or OG488-labeled annexin $V$ binding (mean $\pm \mathrm{SE}$, from $4-6$ donors). ${ }^{* *} P<.001$, and ${ }^{*} P<.05$ compared with single antibody controls. (B) Representative phase-contrast images after perfusion, also showing visible collagen fibers. Original magnification, $x 60$.

In contrast, combined blocking of GPIb and $\alpha 2 \beta 1$ had a less dramatic effect on platelet deposition and aggregation because significant numbers of small aggregates could still be observed. Surface coverage after combined blockade of GPIb with $\alpha 2 \beta 1$ was reduced by approximately $70 \%$ (Figure $7 \mathrm{~A}$ ), a greater effect than achieved by blocking either receptor individually $(P<.05)$. The remaining platelets were in an activated state, judged by the relatively high surface coverage of PS-exposing platelets and the apparent increase in Pi to 0.72. In conclusion, our data show that GPIb and $\alpha 2 \beta 1$ have partially overlapping functions in mediating human platelet adhesion and GPVIdependent thrombus formation. 

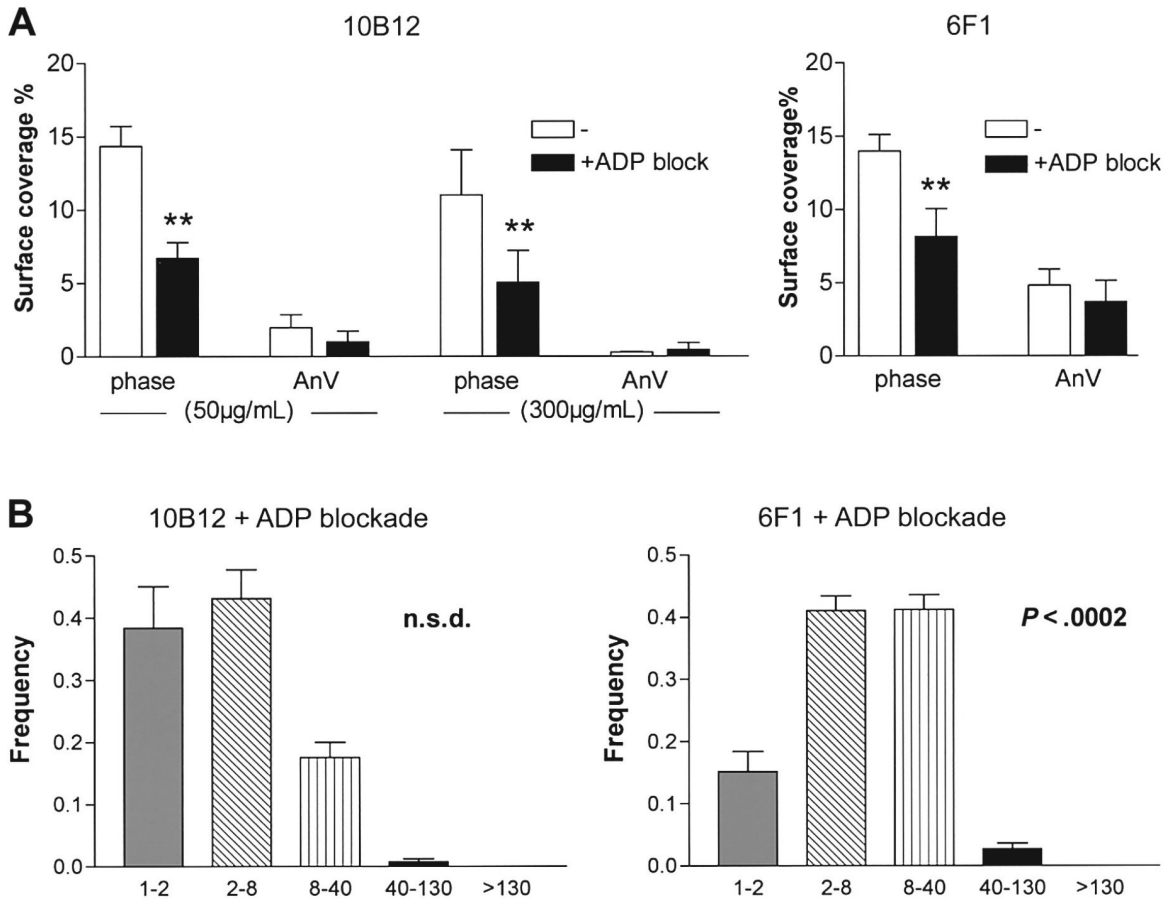

Figure 8 ADP antagonism further reduces thrombus formation after the inhibition of GPVI or $\alpha 2 \beta 1$. Blood was treated with $10 \mathrm{~B} 12$ at 50 or $300 \mu \mathrm{g} / \mathrm{mL}, 6 \mathrm{~F} 1$ at $20 \mu \mathrm{g} / \mathrm{mL}$ with or without ADP receptor antagonism (40 $\mu \mathrm{M}$ MRS2179, $20 \mu \mathrm{M}$ AR-C69 931MX, and $1 \mathrm{U} / \mathrm{mL}$ apyrase). (A) Total surface coverage of platelets and of annexin $\mathrm{V}$-positive platelets was measured (mean $\pm \mathrm{SE}$ from 4-6 donors). ${ }^{* *} P<.01$ compared with control condition. (B) Histograms of feature sizes from phase-contrast micrographs, determined as in Figure 2, where individual antibody effects are

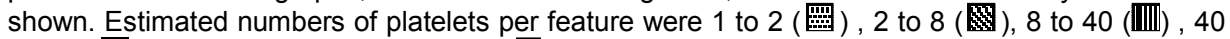
to $130(\square)$, and more than 130 platelets $(\square)$. Data are means \pm SE from 3 donors.

\section{Blocking of ADP receptors further inhibits thrombus formation restricted by GPVI or $\alpha 2 \beta 1$ blockade}

$A D P$ regulation of thrombus size has been attributed to the platelet $P 2 Y_{12}$ purinergic receptor; $P 2 Y_{1}$ regulates the onset of thrombus formation ${ }^{41}$. To obliterate any effects of ADP, we used apyrase in conjunction with specific $P 2 Y_{12}$ and $P 2 Y_{1}$ inhibitors. Full inhibition of ADP- or TxA2-mediated (inhibited by ASA) effects reduced the surface coverage by $43 \%(P<.001)$. The morphology of platelet deposition was similar to that under GPVI blockade: a layer of single platelets remained on the collagen (Figure $1 \mathrm{H}$ ), and aggregates were eradicated (Figure 3E). However, combined blockade of ADP and TxA2 actions had no effect on $\mathrm{Pi}(0.53 \pm 0.15$ [not significant]) or platelet blebbing, though it slightly reduced the $\mathrm{Ca}^{2+}$ response (Figure $5 \mathrm{G}$ ). 
Inhibiting the ADP pathway further decreased surface coverage when combined with GPVI blockade. Irrespective of the $10 \mathrm{~B} 12$ concentration (50 or $300 \mu \mathrm{g} / \mathrm{mL}$ ), ADP receptor antagonism caused an additional reduction in platelet surface coverage $(55 \%$; $P$ $<.001$ ) (Figure 8A), suggesting that the presence of ADP was not solely derived from GPVI-dependent secretion. Because GPVI inhibition itself abolished aggregate formation, the additional blockade of ADP receptors had no further effect on the mean feature size: $24 \pm 2.6 \mu \mathrm{m} 2$ (ADP + GPVI blockage) and $23 \pm 1.8 \mu \mathrm{m} 2$ (GPVI blockade alone) (Figure 8B). When applied together with 10B12, ADP receptor blockade reduced the number of PS-exposing platelets by attenuating platelet deposition because the $\mathrm{Pi}$ did not significantly decrease.

When the ADP receptors were coinhibited with $\alpha 2 \beta 1(20 \mu \mathrm{g} / \mathrm{mL} 6 \mathrm{~F} 1)$, surface coverage decreased by $41 \%$ (Figure $8 \mathrm{~A}$ ), and the mean aggregate size decreased from $121 \pm 8$ to $44 \pm 4 \mu \mathrm{m} 2(\mathrm{P}<.0002)$ (Figure $8 \mathrm{~B})$. Again, this was accompanied by a small decrease in PS-exposing platelets and an unaltered $\mathrm{Pi}$ value. These results let us conclude that ADP (from various sources) stimulates GPVI- and $\alpha 2 \beta 1$-dependent adhesion and contributes to aggregate formation but is insufficient to promote PS exposure. Thus, platelets respond to ADP by inducing one of the thrombus end points, aggregation, in contrast to full activation through GPVI.

\section{Discussion}

The present study shows that, in humans, collagen-induced thrombus formation under high shear rate requires the orchestrated interplay of several platelet receptors. Using antibodies and peptides allowed clarification of the complementary and overlapping roles of the GPIb/V/IX complex, $\alpha 2 \beta 1$ integrin, GPVI, and the platelet purinergic receptors in the processes of platelet adhesion, aggregation, and procoagulant activity. Our results, though formally in line with the original 2-step adhesion-activation model, also revealed its oversimplification. Although the main role of GPIb is to provide initial contact with collagen-bound VWF, it stabilizes the anchorage of thrombi on collagen together with $\alpha 2 \beta 1$. GPVI is involved in GPIb- and $\alpha 2 \beta 1$-mediated adhesion through activation, and it is the main signaling receptor during thrombus formation. Conversely, $\alpha 2 \beta 1$ assists GPVI in signaling. Complete abrogation of adhesion and subsequent activation thus requires simultaneous inhibition of GPVI together with either GPIb or with $\alpha 2 \beta 1$.

We find that GPVI has a crucial role in regulating human thrombus growth. Inhibiting GPVI resulted in the complete loss of platelet aggregates and the full inhibition 86 
of collagen-induced $\mathrm{Ca}^{2+}$ mobilization and PS exposure. In contrast, the adhesion of single, nonaggregated platelets was not significantly diminished unless ADP was also antagonized, probably eliminating the contribution of $\alpha 2 \beta 1$. These results corroborate findings from earlier flow studies with GPVI-deficient platelets in which the surface coverage equaled that obtained with $\alpha \operatorname{llb} \beta 3$ antagonists $^{6}$. A recent study using the blood of patients with GPVI deficiency also showed the obliteration of collagen-induced thrombus formation though a layer of single platelets was still visible in the PDF-format micrographs ${ }^{42}$, supporting our conclusions. In contrast, these results clearly deviate from those obtained in the first flow study using GPVI-deficient mice ${ }^{13}$, which showed the total abolition of platelet-collagen adhesion. In mice, GPVI function was severely impaired when more than $90 \%$ of receptors are blocked. At the highest level of the scFv 10B12 used here $(300 \mu \mathrm{g} / \mathrm{mL})$, calculated receptor occupancy was $97 \%$, supporting the idea that unaltered platelet adhesion was not caused by the inadequate inhibition of GPVI. Although it is possible that antibody dissociation or displacement by ligand may allow a proportion of GPVI to remain functional during multireceptor interaction under flow, 10B12 caused the near-complete, concentration-dependent abolition of platelet activation processes such as PS exposure, $\mathrm{Ca}^{2+}$ response, and aggregate formation. While this paper was in preparation, a true GPVI knockout model was generated in mice in which thrombus formation was similar to that observed in our study ${ }^{43}$. The reasons for the discrepancies regarding the different mouse data remain to be elucidated.

Both GPIb and $\alpha 2 \beta 1$ were implicated in the primary adhesive step at high shear rate, as others suggested after using recombinant receptors in liposomes ${ }^{44}$. Inhibiting GPIb or $\alpha 2 \beta 1$ on its own, but not GPVI, dramatically reduced the number of collagenadherent platelets, though those remaining became activated. The interplay of GPVI with both receptors is implicit in the near-complete suppression of adhesion using the combined blockade of GPIb and GPVI or $\alpha 2 \beta 1$ and GPVI. This indicates that all 3 receptors are required for optimal adhesion. As a first step, GPIb tethers the platelet, allowing other receptors to interact, which perhaps further regulates GPIb function, as recently reported ${ }^{42,45}$. Adhesion through $\alpha 2 \beta 1$ follows closely, with GPVI and $\alpha 2 \beta 1$ acting interdependently. Initial $\alpha 2 \beta 1$ binding to high-affinity collagen sequences, not requiring activation, supports the weak GPVI-collagen interaction, which, in turn, mediates the switch of the integrin to the high affinity required for stable adhesion. In line with this, blocking GPVI with 10B12 caused a more dramatic (but not full) reduction in surface coverage on collagen type III containing only low-affinity xxxGER sequences, but not on collagen type I containing the high-affinity GFOGER sequence used in this study (P.A.S., 
unpublished data, 2002). Collagen-dependent differences in GPVI inhibition were also observed elsewhere ${ }^{6}$. The failure of $\alpha 2 \beta 1$ blockade to cause further reduction in $\mathrm{Ca}^{2+}$ response and PS exposure in the presence of 10B12 implies that $\alpha 2 \beta 1$ signaling occurs downstream from GPVI. This conclusion was reinforced by almost complete loss of binding to adherent platelets, in the presence of $300 \mu \mathrm{g} / \mathrm{mL} \mathrm{10B12}$, of an antibody that recognizes only the fully activated state of $\alpha 2$-integrin, IAC-1 (7F6) ${ }^{46}$. However, the signaling end points of this study $\left(\mathrm{Ca}^{2+}\right.$, PS exposure, and aggregate size) were measured to identify the contribution of specific receptors rather than to study the detail of the signaling processes, which will be subject to further study.

The present model of human thrombus formation deviates in certain respects from that derived from murine data. Although murine thrombus formation seems to rely more on GPVI, it was recently shown that the interplay of $\alpha 2 \beta 1$ with GPVI is required for full GPVI-induced platelet activation and procoagulant activity, using $\beta 1$-deficient mouse platelets $^{28}$. In addition, in another $\alpha 2(-/-)$ mouse flow model, platelet-collagen interaction was severely impaired ${ }^{47}$. Thus, the main deviation between human and mouse concerns the role of primary receptors in platelet adhesion to collagen under flow. There may be several nonexclusive reasons for discrepancy. First, human $\alpha 2 \beta 1$ may be competent to bind GFOGER sequences in type I collagen but not those of lower affinity, such as GASGER $^{48}$, before GPVI involvement. Second, human $\alpha 2 \beta 1$ may become activated independently of GPVI, perhaps caused by GPIb activity. It has been proposed that GPIb uses the same Fc $\gamma$-mediated signaling pathway as $\mathrm{GPVI}^{49}$, and it reportedly induces rapid $\mathrm{Ca}^{2+}$ signaling under flow ${ }^{50}$. Similarly, the GPVI-independent presence of ADP in the blood may activate $\alpha 2 \beta 1$ at an early stage. Third, the threshold for $\alpha 2 \beta 1$ activation of human platelets may be low, that is, small signals from the slight percentage of GPVI not blocked by $10 \mathrm{~B} 12$ may still be sufficient to trigger $\alpha 2 \beta 1$ for adhesion. Fourth, the human integrin-collagen contact—-though dependent on GPIb and GPVI-may be more prone to autocrine signaling than that in mouse platelets. Finally, the considerable differences in human and murine GPVI structures may influence their contribution to the plateletcollagen interaction. Murine GPVI shares only $64 \%$ homology with the human receptor, and its cytoplasmic domain, half the length of the human 51-amino acid tail, lacks signaling motifs ${ }^{51,52}$. A human-to-mouse mutation, K59E, was shown to decrease GPVI binding to CRP, indicating important differences in the function of human and murine receptors $^{19}$.

After the primary platelet-collagen contact, platelets form aggregates or become procoagulant; both processes contribute to full-blown thrombus formation. We defined 2 
conditions in which the formation of thrombi was inhibited: blocking GPVI and blocking ADP- and $\mathrm{TxA}_{2}$-mediated events. Inhibiting GPVI suppressed aggregate formation and signaling processes, detected as the greatly reduced $\mathrm{Ca}^{2+}$ and procoagulant response. However, ADP/TxA 2 antagonism reduced $\mathrm{Ca}^{2+}$ signaling only slightly, though no aggregates were formed, with no effect on Pi. GPVI regulates aggregate formation through autocrine $A D P / T \times A_{2}$ secretion, in part through synergism with $\mathrm{G}_{\mathrm{i} / \mathrm{q}}$-coupled receptors ${ }^{53}$. We found that ADP contributed to aggregation and primary adhesion but that its influence was not eliminated by GPVI inhibition. This implies that ADP was derived from sources other than GPVI-stimulated platelets.

Platelet aggregation was mostly accompanied by high $\mathrm{Ca}^{2+}$ signaling and PS exposure, even when blocking shear-dependent adhesion through GPIb. The platelets that escaped inhibition were activated, as demonstrated by an unchanged $\mathrm{Pi}$. A notable exception occurred with the blocking of $\alpha 2 \beta 1$ function. $\mathrm{Ca}^{2+}$ signaling, PS exposure, and aggregate formation were all affected. This implies that $\alpha 2 \beta 1$ has an activatory effect on these processes, in synergy with GPVI. Most, if not all, integrins exhibit inside-out and outside-in signaling ${ }^{54}$, suggesting that outside-in signaling from activated $\alpha 2 \beta 1$ can participate in platelet activation. We have previously shown that integrin-mediated adhesion to fibrinogen or collagen increases the responsiveness of platelets toward GPVI agonists ${ }^{55}$. Similar cross-talk between GPVI and $\alpha 2 \beta 1$ also likely controls platelet activation in the present experiments. Previously, others have linked $\alpha 2 \beta 1$ activation with $\alpha \operatorname{llb} \beta 3$ up-regulation ${ }^{56,57}$ and established cross-talk between $\alpha 2 \beta 1$ and $\alpha \operatorname{llb} \beta 3^{58}$.

Together, the results presented here advance the idea that human thrombus formation occurs through the concerted action of several receptors: the interplay of GPIb/V/IX, integrin $\alpha 2 \beta 1$ and GPVI enables platelet deposition, and GPVI in cross-talk with $\alpha 2 \beta 1$ mediates subsequent thrombus formation, additionally supported by ADP. Yet these receptors may not be the only determinants of human platelet collagen interaction because other collagen receptors ${ }^{35,57,59,60}$ may participate in the early stages of platelet contact with collagen, and new receptors are being discovered ${ }^{61,62}$. Ultimately, these other receptors may participate in the interaction and may be shown to allow further finetuning of the receptor cross-talk identified in this study.

\section{Acknowledgements}

We thank Dr Angela Rankin for kindly genotyping the donor blood and Dr Marc van Zandvoort for assisting with multiphoton microscopy. 


\section{References}

1. Siljander PRM, Farndale RW. Platelet receptors: collagen. In: Gresele P, Page CP, Fuster V, Vermylen J, eds. Platelets in thrombotic and non-thrombotic disorders: pathophysiology, pharmacology and therapeutics. Cambridge, United Kingdom: Cambridge University Press. 2002:158-178.

2. Gralnick HR, Kramer WS, McKeown LP, Garfinkel L, Pinot A, Williams SB, Krutzsch H. Platelet adhesion at high shear rates: the roles of von Willebrand factor/GPIb and the $\beta 1$ integrin $\alpha 2 \beta 1$. Thromb Res. 1996;81:113-119.

3. Saelman EU, Nieuwenhuis HK, Hese KM, de Groot PG, Heijnen HF, Sage EH, Williams S, McKeown L, Gralnick HR, Sixma JJ. Platelet adhesion to collagen types I through VIII under conditions of stasis and flow is mediated by GPla/lla ( $\alpha 2 \beta 1$-integrin). Blood. 1994;83:1244-1250.

4. Savage B, Almus-Jacobs F, Ruggeri ZM. Specific synergy of multiple substrate-receptor interactions in platelet thrombus formation under flow. Cell. 1998;94:657-666.

5. Verkleij MW, Morton LF, Knight CG, de Groot PG, Barnes MJ, Sixma JJ. Simple collagen-like peptides support platelet adhesion under static but not under flow conditions, interaction via $\alpha 2 \beta 1$ and von Willebrand factor with specific sequences in native collagen is a requirement to resist shear forces. Blood. 1998;91:3808-3816.

6. Moroi M, Jung SM, Shinmyozu K, Tomiyama Y, Ordinas A, Diaz-Ricart M. Analysis of platelet adhesion to a collagen-coated surface under flow conditions, the involvement of glycoprotein $\mathrm{VI}$ in the platelet adhesion. Blood. 1996;88:2081-2092.

7. Nieuwenhuis HK, Akkerman JW, Houdijk WP, Sixma JJ. Human blood platelets showing no response to collagen fail to express surface glycoprotein la. Nature. 1985;318:470-472.

8. Kehrel B, Balleisen L, Kokott R, Mesters R, Stenzinger W, Clemetson KJ, van de Loo J. Deficiency of intact thrombospondin and membrane glycoprotein la in platelets with defective collagen-induced aggregation and spontaneous loss of disorder. Blood. 1988;71:1074-1078.

9. Handa M, Watanabe K, Kawai Y, Kamata T, Koyama T, Nagai H, Ikeda Y. Platelet unresponsiveness to collagen: involvement of glycoprotein la-lla ( $\alpha 2 \beta 1$ integrin) deficiency associated with a myeloproliferative disorder. Thromb Haemost. 1995;73:521-528.

10. Deckmyn H, Chew SL, Vermylen J. Lack of platelet response to collagen associated with an autoantibody against glycoprotein la: a novel cause of acquired qualitative platelet dysfunction. Thromb Haemost. 1990;64:74-79.

11. Kunicki TJ. The role of platelet collagen receptor (glycoprotein la/lla; integrin $\alpha 2 \beta 1$ ) polymorphisms in thrombotic disease. Curr Opin Hematol. 2001;8:277-285.

12. Jung SM, Moroi M. Signal-transducing mechanisms involved in activation of the platelet collagen receptor integrin $\alpha 2 \beta 1$. J Biol Chem. 2000;275:8016-8026.

13. Nieswandt B, Brakebusch C, Bergmeier W, Schulte V, Bouvard D, Mohtari-Nejad R, Lindhout T, Heemskerk JWM, Zirngibl H, Fässler R. Glycoprotein VI but not $\alpha 2 \beta 1$ integrin is essential for platelet interaction with collagen. EMBO J. 2001;20:2120-2130.

14. Holtkötter O, Nieswandt B, Smyth N, Müller W, Hafner M, Schulte V, Krieg T, Eckes B. Integrin a2-deficient mice develop normally, are fertile, but display partially defective platelet interaction with collagen. J Biol Chem. 2002;277:10789-10794.

15. Heemskerk JWM, Siljander PRM, Bevers EM, Farndale RW, Lindhout T. Receptors and signaling mechanisms in the procoagulant response of platelets. Platelets. 2000;11:301-306.

16. Heemskerk JWM, Siljander P, Vuist WMJ, Breikers G, Reutelingsperger CPM, Barnes MJ, Knight CG, Lassila R, Farndale RW. Function of glycoprotein VI and integrin $\alpha 2 \beta 1$ in the procoagulant response of single, collagen-adherent platelets. Thromb Haemost. 1999;81:782-792.

17. Furihata K, Clemetson KJ, Deguchi H, Kunicki TJ. Variation in human platelet glycoprotein VI content modulates glycoprotein VI-specific prothrombinase activity. Arterioscler Thromb Vasc Biol. 2001;21:1857-1863. 
18. Joutsi-Korhonen L, Smethurst PA, Rankin A, Gray E, IJsseldijk M, Onley CM, Watkins NA, Williamson LM, Goodall AH, de Groot PG, Farndale RW, Ouwehand WH. The low-frequency allele of the platelet collagen signaling receptor glycoprotein $\mathrm{VI}$ is associated with reduced functional responses and expression. Blood. 2003;101:4372-4379.

19. Smethurst PA, Joutsi-Korhonen L, O'Connor MN, Wilson E, Jennings NS, Garner SF, Zhang Y, Knight CG, Dafforn TR, Buckle A, IJsseldijk MJW, de Groot PG, Watkins NA, Farndale $\mathrm{RW}$, Ouwehand $\mathrm{WH}$. Identification of the primary collagen-binding surface on human glycoprotein VI by site-directed mutagenesis and by a blocking phage antibody. Blood. 2004;103:903-911.

20. Knight CG, Morton LF, Peachey AR, Tuckwell DS, Farndale RW, Barnes MJ. The collagenbinding A-domains of integrins $\alpha 1 \beta 1$ and $\alpha 2 \beta 1$ recognize the same specific amino acid sequence, GFOGER, in native (triple-helical) collagens. J Biol Chem. 2000;275:35-40.

21. Coller BS, Beer JH, Scudder LE, Steinberg MH. Collagen-platelet interactions, evidence for a direct interaction of collagen with platelet GP la/lla and an indirect interaction with platelet GP Ilb/Illa mediated by adhesive proteins. Blood. 1989;74:182-192.

22. Takada $\mathrm{Y}$, Puzon W. Identification of a regulatory region of integrin $\beta 1$ subunit using activating and inhibiting antibodies. J Biol Chem. 1993;268:17597-17601.

23. Morton LF, Hargreaves PG, Farndale RW, Young RD, Barnes MJ. Integrin $\alpha 2 \beta 1$-independent activation of platelets by simple collagen-like peptides, collagen teriary (triple-helical) and quaternary (polymeric) structures are sufficient alone for $\alpha 2 \beta 1$-independent platelet reactivity. Biochem J. 1995;306:337-344.

24. Cauwenberghs N, Vanhoorelbeke K, Vauterin S, Westra DF, Romo G, Huizinga EG, Lopez JA, Berndt MC, Harsfalvi J, Deckmyn H. Epitope mapping of inhibitory antibodies against platelet glycoprotein Ib $\alpha$ reveals interaction between the leucine-rich repeat $\mathrm{N}$-terminal and $\mathrm{C}$ terminal flanking domains of glycoprotein Ib $\alpha$. Blood. 2001;98:652-660.

25. Keuren JFW, Ulrichts H, Feijge MAH, Hamulyak K, Deckmyn H, Lindhout T, Heemskerk JWM. Integrin $\alpha \mathrm{llb} \beta 3$ and shear-dependent action of glycoprotein $\mathrm{lb} \alpha$ stimulate plateletdependent thrombin formation in stirred plasma. J Lab Clin Med. 2003;141:350-358.

26. Barnes CS, Krafft B, Frech M, Hofmann UR, Papendieck A, Dahlems U, Gellissen G, Hoylaerts MF. Production and characterization of saratin, an inhibitor of von Willebrand factor-dependent platelet adhesion to collagen. Semin Thromb Hemost. 2001;27:337-348.

27. Onley DJ, Knight CG, Tuckwell DS, Barnes MJ, Farndale RW. Micromolar $\mathrm{Ca}^{2+}$ concentrations are essential for $\mathrm{Mg}^{2+}$-dependent binding of collagen by the integrin $\alpha 2 \beta 1$ in human platelets. J Biol Chem. 2000;275:24560-24564

28. Kuijpers MJE, Schulte V, Bergmeier W, Lindhout T, Brakebusch C, Offermanns S, Fässler R, Heemskerk JWM, Nieswandt B. Complementary roles of glycoprotein VI and $\alpha 2 \beta 1$ integrin in collagen-induced thrombus formation in flowing whole blood ex vivo. FASEB J. 2003;17:685687.

29. Billy D, Briedé JJ, Heemskerk JWM, Hemker HC, Lindhout T. Prothrombin conversion under flow conditions by prothrombinase assembled on adherent platelets. Blood Coagul Fibrinolysis. 1997;8:168-174.

30. Heemskerk JWM, Vuist WMJ, Feijge MAH, Reutelingsperger CPM, Lindhout T. Collagen but not fibrinogen surfaces induce bleb formation, exposure of phosphatidylserine and procoagulant activity of adherent platelets. Evidence for regulation by protein tyrosine kinasedependent $\mathrm{Ca}^{2+}$ responses. Blood. 1997;90:2615-2625.

31. Heemskerk JWM, Willems GM, Rook MB, Sage SO. Ragged spiking in free calcium in ADPstimulated platelets: regulation of puff-like calcium signal in vitro and ex vivo. J Physiol. 2001;535:625-635.

32. Roest M, Sixma JJ, Wu YP, IJsseldijk MJ, Tempelman M, Slootweg PJ, de Groot PG, van Zanten $\mathrm{GH}$. Platelet adhesion to collagen in healthy volunteers is influenced by variation of both $\alpha 2 \beta 1$ density and von Willebrand factor. Blood. 2000;96:1433-1437. 
33. Cadroy Y, Sakariassen KS, Charlet JP, Thalamas C, Boneu B, Sie P. Role of 4 platelet membrane glocoprotein polymorphisms on experimental arterial thrombus formation in men. Blood. 2001;98:3159-5161.

34. Di Paola J, Federici AB, Mannucci PM, Canciani MT, Kritzik M, Kunicki TJ, Nugent D. Low platelet $\alpha 2 \beta 1$ levels in type I von Willebrand disease correlate with impaired platelet function in a high shear stress system. Blood. 1999;93:3578-3582.

35. Siljander $\mathrm{P}$, Lassila R. Studies of adhesion-dependent platelet activation: distinct roles for different participating receptors can be dissociated by proteolysis of collagen. Arterioscler Thromb Vasc Biol. 1999;19:3033-3043.

36. Kamata $\mathrm{T}$, Puzon W, Takada Y. Identification of putative ligand binding sites within I domain of integrin $\alpha 2 \beta 1$ (VLA-2, CD49b/CD29). J Biol Chem. 1994;269:9659-9663.

37. Emsley J, Knight CG, Farndale RW, Barnes MJ, Liddington RC. Structural basis of collagen recognition by integrin $\alpha 2 \beta 1$. Cell. 2000;101:47-56.

38. Alevriadou BR, Moake JL, Turner NA, Ruggeri ZM, Folie BJ, Phillips MD, Schreiber AB, Hrinda ME, McIntire LV. Real-time analysis of shear-dependent thrombus formation and its blockade by inhibitors of von Willebrand factor binding to platelets. Blood. 1993;81:1263-1276.

39. Cauwenberghs N, Meiring M, Vauterin S, van Wyk V, Lamprecht S, Roodt JP, Novak L, Harsfalvi J, Deckmyn H, Kotze HF. Antithrombotic effect of platelet glycoprotein Ib-blocking monoclonal antibody Fab fragments in nonhuman primates. Arterioscler Thromb Vasc Biol. 2000;20:1347-1353.

40. Oury C, Kuijpers MJE, Toth-Zsamboki E, Bonnefoy A, Danloy S, Vreys I, Feijge MAH, De Vos R, Vermylen J, Heemskerk JWM, Hoylaerts MF. Overexpression of the platelet P2X $\mathrm{X}_{1}$ ion channel in transgenic mice generates a novel prothrombotic phenotype. Blood. 2003;101:3969-3976.

41. Remijn JA, Wu YP, Heninga EH, IJsseldijk MJW, van Willigen G, de Groot PG, Sixma JJ, Nurden AT, Nurden P. Role of ADP receptor $P 2 Y_{12}$ in platelet adhesion and thrombus formation in flowing blood. Arterioscler Thromb Vasc Biol. 2002;22:686-691.

42. Goto S, Tamura N, Handa S, Arai M, Kodama K, Takayama H. Involvement of glycoprotein VI in platelet thrombus formation on both collagen and von Willebrand factor surfaces under flow conditions. Circulation. 2002;106:266-272.

43. Kato K, Kanaji T, Russell S, Kunicki TJ, Furihata K, Kanaji S, Marchese P, Reininger A, Ruggeri ZM, Ware J. The contribution of glycoprotein VI to stable platelet adhesion and thrombus formation illustrated by targeted gene deletion. Blood. 2003;102:170-1707.

44. Nishiya T, Kainoh M, Maurata M, Handa M, Ikeda Y. Reconstitution of adhesive properties of human platelets in liposomes carrying both recombinant glycoproteins la/lla and Ib $\alpha$ under flow conditions: specific synergy of receptor-ligand interactions. Blood. 2002;100:136-142.

45. Massberg S, Gawaz M, Grüner S, Schulte V, Konrad I, Zohlhöfer D, Heinzmann U, Nieswandt B. A crucial role of glycoprotein VI for platelet recruitment to the injured arterial wall in vivo. J Exp Med. 2003;197:41-49.

46. Schoolmeester A, Vanhoorelbeke K, Feys $\mathrm{H}$, et. a. Identification of a monoclonal antibody specific for the activated integrin $\alpha 2 \beta 1$ [abstract]. Platelets. 2002;13:359.

47. Chen J, Diacovo TG, Grenache DG, Santoro SA, Zutter MM. The $\alpha 2$ integrin subunit-deficient mouse. A multifaceted phenotype including defects of branching morphogenesis and hemostasis. Am J Pathol. 2002;161:337-344.

48. Xu Y, Gurusiddappa S, Rich RL, Owens RT, Keene DR, Mayne R, Hook A, Hook M. Multiple binding sites in collagen type I for the integrins $\alpha 1 \beta 1$ and $\alpha 2 \beta 1$. J Biol Chem. 2000;275:38981-38989.

49. Wu Y, Suzuki-Inoue K, Satoh K, Asazuma N, Yatomi Y, Berndt MC, Ozaki Y. Role of Fc receptor $\gamma$-chain in platelet glycoprotein Ib-mediated signaling. Blood. 2001;97:3836-3845.

50. Mazzucato M, Pradella P, Cozzi MR, De Marco L, Ruggeri ZM. Sequential cytoplasmic calcium signals in a 2-stage platelet activation process induced by the glycoprotein Ib $\alpha$ mechanoreceptor. Blood. 2002;100:2793-2800. 
51. Clemetson JM, Polgar J, Magnenat E, Wells TN, Clemetson KJ. The platelet collagen receptor glycoprotein $\mathrm{VI}$ is a member of the immunoglobulin superfamily closely related to Fc $\alpha$ R and the natural killer receptors. J Biol Chem. 1999;274:29019-29024.

52. Jandrot-Perrus $M$, Busfield $S$, Lagrue AH, Xiong $X$, Debili $N$, Chickering $T$, Le Couedic JP, Goodearl A, Dussault B, Fraser C, Vainchenker W, Villeval JL. Cloning, characterization, and functional studies of human and mouse glycoprotein VI: a platelet-specific collagen receptor from the immunoglobulin superfamily. Blood. 2000;96:1798-1807.

53. Nieswandt B, Bergmeier WG, Eckly A, Schulte V, Ohlmann P, Cazenave JP, Zirngibl H, Offermanns S, Gachet C. Evidence for cross-talk between glycoprotein VI and Gi-coupled receptors during collagen-induced platelet aggregation. Blood. 2001;97:3829-3835.

54. Hynes RO. Integrins: bidirectional, allosteric signaling machines. Cell. 2002;110:673-687.

55. Siljander P, Farndale RW, Feijge MAH, Comfurius P, Kos S, Bevers EM, Heemskerk JWM. Platelet adhesion enhances the glycoprotein VI-dependent procoagulant response: involvement of p38 MAP kinase and calpain. Arterioscler Thromb Vasc Biol. 2001;21:618-627.

56. Kehrel B, Wierwille S, Clemetson KJ, Anders O, Steiner M, Knight CG, Farndale RW, Okuma $M$, Barnes MJ. Glycoprotein VI is a major collagen receptor for platelet activation: it recognizes the platelet-activating quaternary structure of collagen, whereas CD36, glycoprotein Ilb/llla, and von Willebrand factor do not. Blood. 1998;91:491-499.

57. Nakamura T, Kambayashi JI, Okuma M, Tandon NN. Activation of the GPIIb/IIla complex induced by platelet adhesion to collagen is mediated by both $\alpha 2 \beta 1$ integrin and GPVI. J Biol Chem. 1999;274:11897-11903.

58. Riederer MA, Ginsberg MH, Steiner B. Blockade of platelet GPIIB-IIIA (Integrin $\alpha$ llb $\beta 3$ ) in flowing human blood leads to passivation of prothrombotic surfaces. Thromb Haemost. 2002;88:858-864.

59. Monnet E, Fauvel-Lefève F. A new platelet receptor specific to type III collagen: type III collagen-binding protein. J Biol Chem. 2000;275:10912-10917.

60. Monnet E, Sizaret P, Arbeille B, Fauvel-Lafeve F. Different role of platelet glycoprotein GP Ia/lla in platelet contact and activation induced by type I and type III collagens. Thromb Res. 2000;98:423-433.

61. Moog S, Mangin P, Lenain N, Strassel C, Ravanat C, Schuhler S, Freund M, Santer M, Kahn M, Nieswandt B, Gachet C, Cazenave JP, Lanza F. Platelet glycoprotein V binds to collagen and participates in platelet adhesion and aggregation. Blood. 2001;98:1038-1046.

62. Chiang TM, Cole F, Woo-Rasberry V. Cloning, characterization, and functional studies of a 47-kDa platelet receptor for type III collagen. J Biol Chem. 2002;277:34896-34901. 



\section{Chapter 5}

\section{The glycoprotein VI-phospholipase $\mathbf{C} \gamma \mathbf{2}$}

signaling pathway controls thrombus formation induced by collagen and tissue factor in vitro and in vivo

Imke C. A. Munnix, Amrei Strehl, Marijke J. E. Kuijpers, Jocelyn M. Auger, Paola E. J. van der Meijden, Marc A. M. van Zandvoort, Mirjam G. A. oude Egbrink, Bernhard Nieswandt and Johan W. M. Heemskerk

Arterioscler Thromb Vasc Biol 2005; 25: 2673-2678

Reprinted with permission 


\begin{abstract}
Both collagen and tissue factor can be initiating factors in thrombus formation. We investigated the signaling pathway of collagen-induced platelet activation in interaction with tissue factor-triggered coagulation during the thrombus-forming process. In murine blood flowing over collagen, platelet exposure of phosphatidylserine and procoagulant activity, but not adhesion, completely relied on each of the following signaling modules: glycoprotein VI (GPVI), FcR $\gamma$-chain, Src kinases, adaptor protein LAT, and phospholipase C $\gamma 2$ (PLCY2). Upon flow in the presence of tissue factor, these signaling components were essential for platelet aggregation and greatly enhanced fibrin clot formation. Collagen-stimulated thrombin generation relied on the presence and activity of GPVI, FCR $\gamma$-chain, Src kinase, LAT and PLCY2. The physiological importance of this GPVI pathway was shown in a $\mathrm{FeCl}_{3}$-induced in vivo murine thrombosis model. In both venules and arterioles, signaling through GPVI, FcR $\gamma$-chain and Src kinases enhanced the formation of phosphatidylserine-exposing and fibrin-rich thrombi. In conclusion, the GPVI-PLCY2 activation pathway regulates collagen-dependent coagulation in venous and arterial thrombus formation.
\end{abstract}

\title{
Introduction
}

Thrombus formation can be initiated by both platelet- and coagulationactivating factors. Collagens in the extracellular matrix and other vascular layers are though to act as principal platelet-activating components of the damaged vessel wall; they also provide a surface for von Willebrand factor (vWf) adhesion ${ }^{1}$. Tissue factor, also exposed in damaged vessels, is a key trigger of the coagulation process ${ }^{2}$. Because of the proposed major role of platelets in arterial thrombosis and the importance of coagulation in venous thrombosis, current understanding is that collagen/vWf-mediated events are more important in arteries, while tissue factor plays a more prominent role in venous thrombus formation.

Flow studies with human and mouse blood have established that the signaling receptor, glycoprotein VI (GPVI), exclusively mediates collagen-induced platelet procoagulant activity, thus linking the processes of platelet activation and coagulation ${ }^{3-5}$. This procoagulant platelet response is mediated by a prolonged and potent rise in cytosolic $\left[\mathrm{Ca}^{2+}\right]_{\mathrm{i}}$, which results in exposure of procoagulant phosphatidylserine (PS) at the platelet outer surface ${ }^{6}$. PS exposure is a key regulating factor in the coagulation process. For instance, PS-containing membrane surfaces dramatically increase the 
formation of factor Xa and thrombin ${ }^{7}$. However, several authors have argued that this platelet response has only an assistant role in coagulation and that, in vivo, other platelet reactions may play important roles as well ${ }^{2,8}$. Thus, while there is no doubt that platelets enhance thrombin generation (coagulation) in plasma or whole blood, the precise mechanism is still a matter of debate.

The platelet immunoreceptor GPVI is co-expressed with the Fc receptor (FcR) $\gamma$-chain, although the latter also interacts with other platelet receptors, e.g. GPIb ${ }^{9}$ In human and mouse platelets, activation of GPVI by collagen or other ligands results in a complex cascade of signaling events ${ }^{10-12}$. The initial step is tyrosine phosphorylation of the FcR $\gamma$-chain by the Src family kinases, Fyn and Lyn. Subsequent activation of the tyrosine kinase Syk leads to phosphorylation of multiple signaling proteins, including the adaptor proteins LAT, SLP-76 and SLAP-130, and further the G-protein regulator Vav and phospholipase C- $\gamma 2(\mathrm{PLC} \gamma 2)^{13}$. GPVI stimulation activates various other protein kinases, including Btk, Tec, phosphoinositide 3-kinase and, further downstream, protein kinase $C$, Erk1/2 and focal adhesion kinase, as a result of which platelets respond by integrin activation, $\mathrm{Ca}^{2+}$ increase, aggregation, shape change, secretion and procoagulant activity. Although earlier work has shown that GPVI plays a key role in the collagen-induced platelet procoagulant activity in both stasis and flow ${ }^{14}$, it is still unclear which signaling elements downstream of GPVI contribute to this platelet reaction.

Evidence that GPVI plays a key role in arterial thrombosis comes from recent in vivo studies with mice, where the platelet aggregation in vivo was followed after ligation of arteries, causing exposure of vascular collagen ${ }^{1,15}$. Absence of GPVI (as in FcR $\gamma$ chain null mice) or down-regulation of GPVI (as in mice treated with JAQ1 antibody) appeared to suppress intravascular formation of platelet aggregates. Thus, knowing the in vitro evidence for a procoagulant effect of GPVI, we hypothesized that GPVI can also drive the coagulation process during thrombus formation.

In the present study, we used mice deficient in GPVI or in one of the signaling proteins downstream of GPVI to investigate the signal transduction route leading to GPVI-induced PS exposure, coagulation stimulation and fibrin formation both in vitro and in vivo. We performed whole-blood flow studies partly in the presence of tissue factortriggered coagulation to determine the functional effects of PS exposure. Furthermore, in vivo experiments where thrombus formation was induced with free radical-forming $\mathrm{FeCl}_{3}$, allowed us to study the importance of this process in a thrombosis model known to rely on thrombin generation and coagulation ${ }^{16}$. The data showed that also in vivo the 
signaling cascade from GPVI to PLC $\gamma 2$ led to coagulant activity and enhanced thrombus formation.

\section{Materials and Methods}

\section{Materials}

Fibrillar type-I collagen (Horm) was purchased from Nycomed (Munich, Germany). MRS2179, a P2Y 1 antagonist, was from Sigma (St. Louis, Mo, USA). Annexin A5 labeled with Oregon green 488 (OG488) came from Nexins Research (Hoeven, The Netherlands). OG488-conjugated fibrinogen and annexin A5 labeled with Alexa fluor 647 (AF647) were from Molecular Probes (Leiden, The Netherlands). PD173952 was a gift from Pfizer (Ann Arbor, MI, and Sandwich, UK).Lotrafiban was a gift from GlaxoSmithKline (Middlesex, UK). Anti-GPVI antibody JAQ1 was produced and modified as described ${ }^{9}$; Fab fragments were generated and in part used for fluorescein labeling ${ }^{3}$. Blocking anti-murine GPIb monoclonal antibody (mAb) Xia.B2 was from Emfret Analytics (Würzburg, Germany). ARC69931MX, an antagonist of the P2Y 12 receptor, was from AstraZeneca R\&D (Charnwood, UK). Aspirin was from Lorex Synthélabo (Maarssen, The Netherlands). Recombinant tissue factor came from Dade (Düdingen, Switzerland); ZGly-Gly-Arg aminomethyl coumarin (Z-GGR-AMC) from Bachem (Bubendorf, Switzerland); H-Phe-Pro-Arg chloromethyl ketone (PPACK) from Calbiochem (La Jolla, $\mathrm{CA}$ ); $\mathrm{FeCl}_{3}$ from Merck (Darmstadt, Germany). Other materials were obtained from sources described before ${ }^{3}$.

\section{Animals and blood collection}

Healthy 4-5 weeks old (11-21 g) or 12 week old C57BI/6 (20-25 g) (wildtype) mice of either sex were obtained from Charles River (Maastricht, The Netherlands). C57BI/6 mice deficient in the FcR Y-chain (-/-) were obtained from Taconics (Germantown, NY). Mice homozygously deficient in LAT or PLCY2 were generated as described previously ${ }^{17,18}$, and bred from heterozygotes on a B6 background. Wildtype littermates were used as controls. Where indicated, wildtype mice were injected under anesthesia with $100 \mu \mathrm{g}$ anti-GPVI JAQ1 antibody (in $100 \mu \mathrm{L}$ saline) at 5 days before start of the experiment. Other anesthetized animals were injected with $100 \mu \mathrm{L}$ of $1 \mathrm{mM} \mathrm{Src}$ kinase inhibitor, PD173952 (diluted in saline), at $10 \mathrm{~min}$ before experimentation. Efficacy of these treatments was verified with collected blood by flow cytometry and platelet aggregation measurements. For experiments in the absence of coagulation, blood was 98 
collected under anesthesia by orbital puncture in $40 \mu \mathrm{M}$ PPACK and $5 \mathrm{U} / \mathrm{mL}$ heparin, as described $^{3}$. For experiments involving coagulation, blood was collected into $10 \% 0.129$ $\mathrm{M}$ citrate. Studies were approved by the local animal care and use committees.

\section{Thrombus formation on collagen under flow}

Thrombus formation was measured ex vivo with blood from 12 week old mice which was perfused over a collagen surface as described before ${ }^{4}$. Briefly, an area of $20 \times 5 \mathrm{~mm}$ in the centre of a glass coverslip was coated with fibrillar Horm type-I collagen $\left(50 \mu \mathrm{g} / \mathrm{mL}\right.$ for $20 \mathrm{~min}$ at $37^{\circ} \mathrm{C}$ ), blocked with Hepes buffer $\mathrm{pH} 7.45$ (5 mM Hepes, 136 $\mathrm{mM} \mathrm{NaCl}, 2.7 \mathrm{mM} \mathrm{KCl}, 0.42 \mathrm{mM} \mathrm{NaH}_{2} \mathrm{PO}_{4}$ and $1 \%$ bovine serum albumin (BSA), and then placed in a parallel plate flow chamber (slit depth of $50 \mu \mathrm{m}$ ). Blood was incubated for $15 \mathrm{~min}$ with various inhibitors and/or fluorescent probes, and then perfused over the coverslip at a shear rate of $150-1000 \mathrm{~s}^{-1}$ for $4 \mathrm{~min}$. Thereafter, the flow chamber was perfused with Hepes buffer $\mathrm{pH} 7.45$ with $2 \mathrm{mM} \mathrm{CaCl}_{2}$ and $1 \mathrm{U} / \mathrm{mL}$ heparin and containing fluorescent-labeled annexin A5 $(0.5 \mu \mathrm{g} / \mathrm{mL})$ for $4 \mathrm{~min}$. Bright-field phase contrast as well as non-confocal fluorescence images of adherent platelets were recorded using a Visitech microscope system equipped with two cameras ${ }^{5}$ or an inverted stage video microscope system (DM-IRB, Leica, UK) ${ }^{19}$. To inhibit GPIb activity we used the blocking anti-murine GPIb $\alpha$ mAb Xia.B2 $(40 \mu \mathrm{g} / \mathrm{ml})$, which was demonstrated to be equally effective as the earlier used blocking anti-GPIb antibody p0p/B (B. Nieswandt, unpublished results).

For flow experiments without coagulation, blood collected in PPACK/heparin was used. For coagulation experiments, citrated whole blood was used, which was during perfusion exposed to $10 \%$ volume of $20 \mathrm{pM}$ tissue factor in $200 \mathrm{mM} \mathrm{CaCl}_{2}$ upon entry into the flow chamber, as described for rat and human blood ${ }^{5}$. Platelet surface coverage of images was analyzed using ImagePro software (Media Cybernetics, Silver Spring, MD) for phase contrast images and Quanticell software (Visitech, Sunderland, UK) for fluorescent annexin A5 images. At least 10 different fields of view were averaged per experiment (no image processing).

\section{Two-photon laser scanning microscopy (TPLSM)}

For two-photon laser scanning microscopy (TPLSM), coverslips with thrombi were observed with a Bio-Rad 2100 multiphoton system. Excitation was by a SpectraPhysics Tsunami Ti:Sapphire laser, tuned and mode-locked at $800 \mathrm{~nm}$, producing pulses of $100 \mathrm{fs}$ wide (repetition rate $82 \mathrm{MHz}$ ). Excitation at $647 \mathrm{~nm}$ was by a parallel-placed red 
diode laser. Fluorescence was detected at 508 to $523 \mathrm{~nm}$ and above $660 \mathrm{~nm}$. Thrombi in flow chambers, double labeled with OG-488 fibrinogen (green) and AF647-annexin A5 (red), were scanned at the end of perfusions. Optical sections were recorded in Kalman filtering mode; no further image processing was performed. Mouse mesenteric vessels were imaged in situ using TPLSM, taking advantage of the high penetration depth and intrinsically high optical sectioning of this technique ${ }^{20}$.

\section{Thrombin generation measurement}

Murine platelet-rich plasma (PRP) and platelet-poor plasma (PPP) collected on citrate were used to measure thrombin generation with the thrombogram method ${ }^{21}$, adapted for murine plasma. Briefly, normalized PRP $\left(1.5 \times 10^{8}\right.$ platelets $\left./ \mathrm{mL}\right)$ was preincubated with an antagonist for $15 \mathrm{~min}$ and then with collagen for $10 \mathrm{~min}$. Samples of $40 \mu \mathrm{L}$ PRP or PPP were pipetted into wells of a 96-well plate (Immulon 2HB; Dynex Technologies, Chantilly, VA), containing $10 \mu \mathrm{L}$ tissue factor (6 pM) in buffer A (20 mM Hepes, $140 \mathrm{mM} \mathrm{NaCl}, 5 \mathrm{mg} / \mathrm{mL}$ BSA, pH 7.35). Coagulation was started by addition of $10 \mu \mathrm{L}$ Z-GGR-AMC (2.5 mM), dissolved in buffer B (20 mM Hepes, $100 \mathrm{mM} \mathrm{CaCl}_{2}, 60$ $\mathrm{mg} / \mathrm{mL}$ BSA, $\mathrm{pH}$ 7.35). Plates were immediately inserted into a fluorescence well-plate reader (Thermolab Systems, Helsinki, Finland or Molecular Devices, Spectra Max Gemini XS) and processed at $37^{\circ} \mathrm{C}^{22}$. Fluorescence accumulation from cleaved AMC was measured, and first derivative curves of accumulation of fluorescence were generated; calibrations were performed with human thrombin.

\section{Animal preparation and intravital microscopy}

Four to 5-week old mice were anesthetized by subcutaneous injection of 0.1 $\mathrm{mg} / \mathrm{g}$ body weight ketamine and $0.02 \mathrm{mg} / \mathrm{g}$ xylazine. Anesthesia was maintained by continuous infusion of ketamine $(0.07 \mathrm{mg} / \mathrm{g} / \mathrm{h})$ through a subcutaneous polyethylene (PE)-10 catheter in the neck. Pharmacological agents were administered intravenously through a PE-10 catheter in the tail vein. Body temperature was kept at $37^{\circ} \mathrm{C}$ using an infrared heating lamp, controlled by a thermoanalyzer system connected to a rectal probe.

A segment of the ileum was exteriorized through a right side abdominal incision. The mesentery was spread over a siliconized glass plate mounted on an electrically heated table $\left(37^{\circ} \mathrm{C}\right)$ of a Leitz (Jena, Germany) intravital microscope, and continuously superfused with a Tyrode solution $(130 \mathrm{mM} \mathrm{NaCl}, 5.6 \mathrm{mM} \mathrm{KCl}, 2.2 \mathrm{mM} \mathrm{CaCl}, 0.56 \mathrm{mM}$ $\mathrm{MgCl}_{2}, 11 \mathrm{mM}$ glucose, $13 \mathrm{mM}$ sucrose, $25 \mathrm{mM} \mathrm{NaHCO}_{3}$ and $1.2 \mathrm{mM} \mathrm{NaH}_{2} \mathrm{PO}_{4}$; pH 7.35 
at $37^{\circ} \mathrm{C}$ ), supplemented with $1 \mu \mathrm{g} / \mathrm{mL}$ isoprenaline and saturated with $95 \% \mathrm{~N}_{2}$ and $5 \%$ $\mathrm{CO}_{2}$. The exteriorized ileum was kept moist with overlying wet gauze. Where indicated, fluorescently labeled compounds were infused (bolus, $100 \mu \mathrm{L}$ ) via the tail vein catheter either before or after $\mathrm{FeCl}_{3}$ application.

\section{Thrombus formation in vivo}

For in vivo experiments, fat-free mesenteric arterioles and proximate venules were selected. Before start of $\mathrm{FeCl}_{3}$ application, superfusion with Tyrode solution was stopped, and remaining fluid was carefully removed from the selected mesenteric tissue. Vessel wall damage was induced by topical application of $30 \mu \mathrm{L} \mathrm{FeCl}_{3}(500 \mathrm{mM})$, which remained on the tissue during experimentation. The intravascular reactions were observed by trans-illumination and fluorescence microscopy using a LL25x objective (NA 0.35) and a CCD camera (Hamamatsu) for $600 \mathrm{~s}^{23}$. For each vessel, the following parameters were quantified off-line: lagtime to first observation of thrombus formation, thrombus height perpendicular to the vessel wall (percentage of the vessel diameter) at 2, 5 and 10 min after $\mathrm{FeCl}_{3}$ application. Damaged mesenteric vessels were observed in situ, as described above, while specimens for histology were fixed in formaldehyde $(10 \%$ in PBS), routinely processed and embedded in paraffin. Sections of $4 \mu \mathrm{m}$ were cut and stained with hematoxylin and eosin.

To determine wall shear rates in representative mesenteric arterioles and venules, several mice were injected with rhodamin $6 \mathrm{G}$ (30 $\mu \mathrm{L}$ of $1 \mathrm{mg} / \mathrm{mL}$, intravenous) for labeling of circulating leucocytes. Fluorescence microscopy was applied to quantify centerline blood flow velocities of passing leucocytes, as described. Mean wall shear rates were $1183 \mathrm{~s}^{-1}$ in arterioles and $344 \mathrm{~s}^{-1}$ in venules.

\section{Statistical analysis}

Data from in vivo experiments displayed non-symmetrical distribution and are presented as median values with interquartile ranges. Differences between experimental groups were tested on significance with a non-parametric Mann-Whitney $U$ test using the statistical package for social sciences (SPSS 11.0, Chicago, IL). 


\section{Results}

\section{Components of the GPVI-PLC $\gamma 2$ signaling pathway required for collagen-induced}

\section{procoagulant activity of platelets in flowing blood}

In mouse and human platelets, functional activity of GPVI is required for collagen-induced aggregation and surface exposure of procoagulant $P S^{4,5}$. To investigate which signaling proteins downstream of GPVI are involved in the procoagulant platelet response, we used genetically modified mice and specific blockers

A
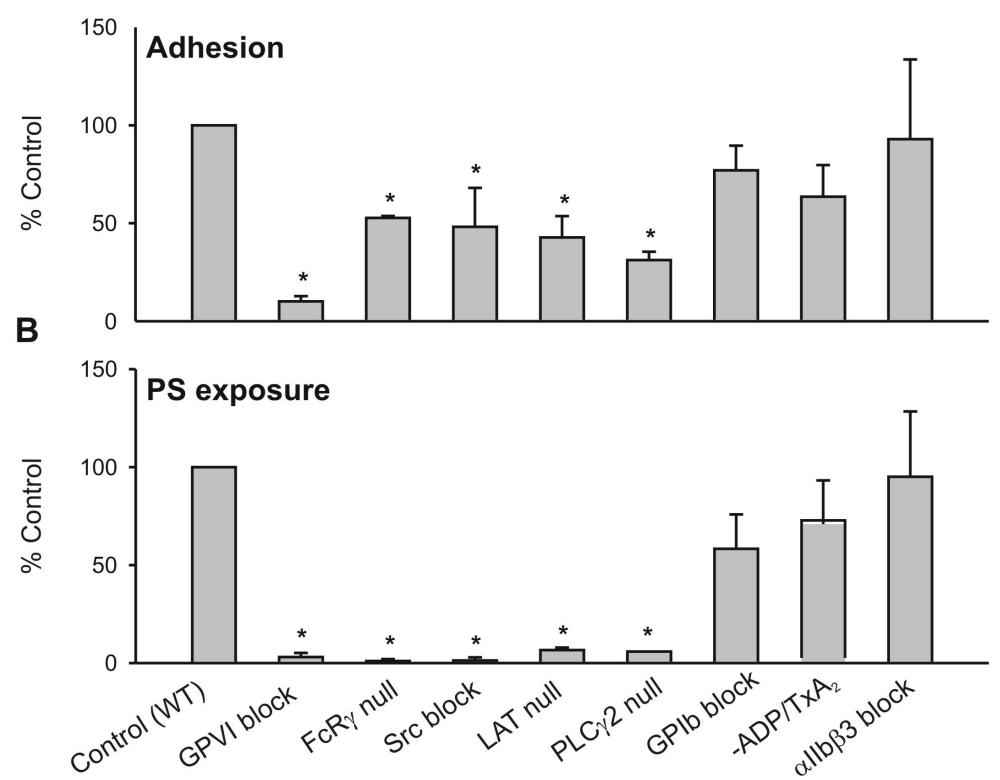

GPVI signalling pathway

Secondary responses

Figure 1 GPVI-PLC $\gamma 2$ signaling pathway is required for collagen-induced PS exposure in flowing blood. PPACK-anticoagulated blood was perfused over collagen in the absence of coagulation. Perfusion was at $1000 \mathrm{~s}^{-1}$ for $4 \mathrm{~min}$, followed by staining with fluorescent annexin A5 $(0.5 \mu \mathrm{g} / \mathrm{mL})$. Wildtype blood was pre-incubated for $15 \mathrm{~min}$ with vehicle (control), $40 \mu \mathrm{g} / \mathrm{mL} \mathrm{JAQ1}$ Fab (blocking GPVI) or $25 \mu \mathrm{M}$ PD173952 (blocking Src kinases). Blood from mice lacking FcR $\gamma$ chain, LAT or PLC $\gamma 2$ was compared to blood from genetically matched wildtype mice. Otherwise, wildtype blood was pre-treated with vehicle or $40 \mu \mathrm{g} / \mathrm{mL}$ Xia.B2 mAb (blocking GPIba), $10 \mu \mathrm{M}$ lotrafiban (blocking integrin $\alpha$ llb $\beta 3$ ) or $20 \mu \mathrm{M}$ MRS2179, $50 \mu \mathrm{M}$ AR-C69931MX and $100 \mu \mathrm{M}$ aspirin (blocking effects of autocrine ADP/thromboxane $A_{2}$ ). Data represent surface area coverage of all platelets (A) and of PS-exposing platelets (B), expressed as percentage of corresponding controls. Surface area coverage with wildtype platelets under control conditions was $17.5 \pm 5.5 \%$, and coverage with fluorescent annexin A5 was $7.2 \pm 4.1 \%$. Mean \pm SD ( $n=5-7)$; ${ }^{*} P \leq 0.05$ compared to control. 
of key proteins in the PLC $\gamma 2$ activation pathway. We used Fab fragments of JAQ1 mAb to block GPVI receptors and, in comparison, GPVI-null mice lacking the FcR $\gamma$-chain. Src kinase activity was abolished with the compound PD173952, which has recently been identified as a selective and specific inhibitor of Src-family kinases that is still active in blood. It essentially abolishes all collagen- but not thrombin-induced tyrosine phosphorylation events in platelets ${ }^{19}$. Furthermore, mice deficient in $\mathrm{LAT}^{18}$ or PLCY2 ${ }^{17}$ were used to study the contribution of these downstream signaling entities.

In the first experiments, PPACK-anticoagulated whole blood from wildtype or genetically modified mice was perfused over a collagen surface at a shear rate of $1000 \mathrm{~s}^{-1}$, i.e. representative of that found in murine arterioles. Using wildtype blood, platelets rapidly adhered to the collagen surface and partly assembled into aggregates. As shown before ${ }^{4,24}$, platelet deposition and aggregate growth on collagen increased about linearly with time. Blocking of GPVI with JAQ1 Fab fragments abolished platelet adhesion and aggregation (Figure 1A), also confirming earlier results ${ }^{4,15}$. Absence of FcR $\gamma$ or treatment with Src kinase inhibitor resulted in a moderately reduced deposition of platelets on collagen; these platelets remained single and showed little tendency to aggregate. Similar results were obtained with blood from LAT-null or PLCY2-null mice (Figure 1A).

Post-staining of wildtype/control thrombi with OG488-annexin A5 revealed many single PS-exposing platelets (Figure 1B). Strikingly, virtually no PS-exposing platelets were detected when: GPVI was blocked (with JAQ1 Fab), FcR $\gamma$-chain was absent, Src kinases were blocked (with PD173952), or LAT or PLCY2 was absent (Figure 1B). In sharp contrast, platelet deposition was only little affected by either blocking of GPIb-vWf interactions (with Xia.B2 $\mathrm{mAb}$ ), secondary platelet responses due to release of ADP (with receptor antagonists MRS2179 and AR-C69931MX), thromboxane $A_{2}$ (aspirin), or by blocking integrin $\alpha$ llb $\beta 3$ (with lotrafiban) (Figure $1 \mathrm{~A}$ ). Also, these blocking conditions did not significantly influence PS exposure compared to the control situation (Figure 1B).

A typical observation under control conditions was that wildtype platelets on the collagen surface only showed PS exposure when not assembled into aggregates. Conversely, aggregated platelets did not expose PS. We used the high resolution of TPLSM, allowing simultaneous detection of two fluorescent probes, to better characterize the populations of PS-exposing and aggregated platelets. With OG488fibrinogen and AF647-annexin A5 added to wildtype blood, fibrinogen label exclusively incorporated into platelet aggregates, whereas labeled annexin A5 was differently localized, only staining single platelets around the aggregates. After perfusion, platelets from FcR $\gamma$-chain null mice and also wildtype platelets treated with PD173952 failed to 
bind fibrinogen, pointing to the requirement of the FcR $\gamma$-chain and Src kinases to the aggregate-forming process ${ }^{19}$. Together, these results indicate that the signaling components of the GPVI-PLCy2 pathway (involving Src kinases, FcR $\gamma$, Syk and LAT) are indispensable for PS exposure on collagen under flow. The PS-exposing platelets typically represent a different population than the platelets assembled into aggregates and binding fibrinogen.

\section{Components of the GPVI signaling pathway determining platelet procoagulant} activity and thrombus formation in flowing blood triggered with tissue factor

To induce coagulation under flow conditions, citrated blood was mixed with tissue factor and $\mathrm{CaCl}_{2}$ just before entering the flow chamber. The perfusion protocol was such that coagulation occurred at physiological, millimolar $\mathrm{Mg}^{2+}$ and $\mathrm{Ca}^{2+}$ concentrations ${ }^{25}$. With wildtype blood, perfusion in the presence of tissue factor resulted in PS exposure and the formation of platelet aggregates, which gradually transformed to

\section{Tissue factor}
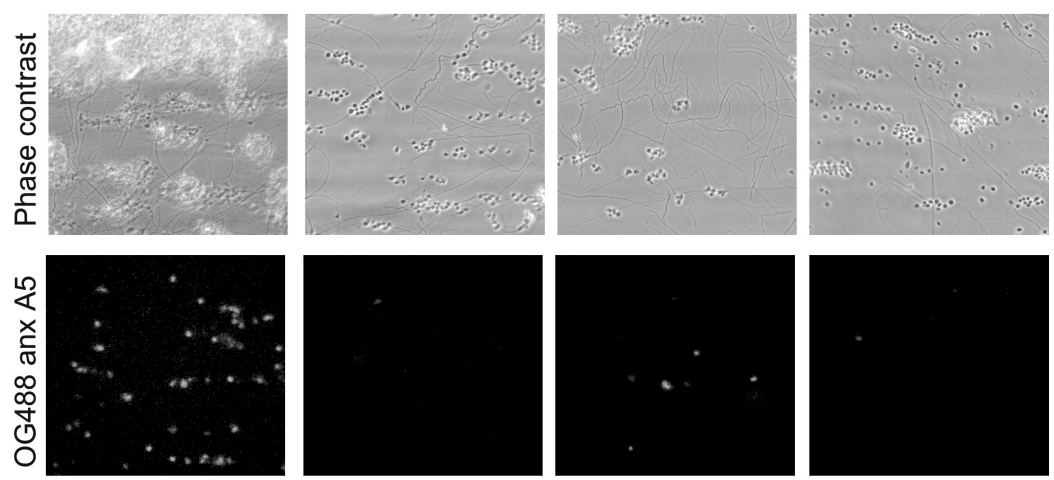

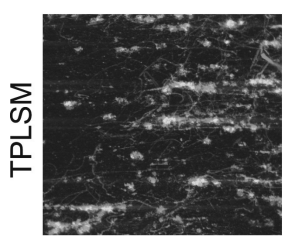

WT control

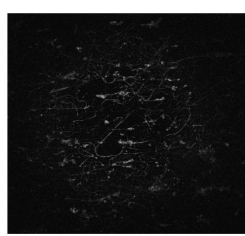

GPVI block

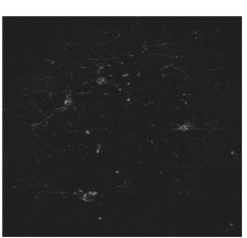

FcR $\gamma$ null

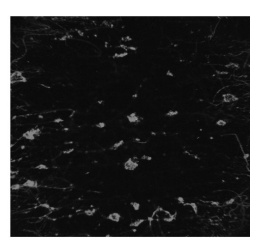

Src block

Figure 2 GPVI/FcR $\gamma$-chain signaling pathway controls tissue factor-induced fibrin formation and platelet activation in flowing blood. Citrate blood from wildtype mice was incubated for 15 min with vehicle, GPVI-blocking JAQ1 Fab, or Src kinase inhibitor PD173952 (see Figure 1). Blood was then perfused over collagen together with tissue factor (2 pM, f.c.) and $\mathrm{CaCl}_{2}\left(2 \mathrm{mM}\right.$ free $\mathrm{Ca}^{2+}$, f.c.) to allow coagulation. Standard perfusion time was $4 \mathrm{~min}$ at shear rate of $1000 \mathrm{~s}^{-1}$. Postlabeling was with OG488-annexin A5 $(0.5 \mu \mathrm{g} / \mathrm{mL})$. Upper panels: phase-contrast images after perfusion $(120 \times 120 \mu \mathrm{m})$; middle panels: images of OG488-annexin A5 fluorescence (different fields, $150 \times 150 \mu \mathrm{m})$; lower panels: TPLSM images of OG488-fibrinogen and AF647-annexin A5 fluorescence $(77 \times 77 \mu \mathrm{m})$. Images are representative of 5-10 experiments. 
clots trapping erythrocytes (Figure 2). TPLSM analysis indicated that the thrombi contained extensive networks of fibrin and aggregated platelets, which were surrounded by single PS-exposing platelets. Perfusion of JAQ1-treated blood (with blocked GPVI) or blood from FcR $\gamma$-null mice in the presence of tissue factor gave only limited platelet adhesion without aggregate formation. Fibrin formation was greatly suppressed, and only few PS-exposing platelets were observed (Figure 2). PD173952 was somewhat less inhibitory in the presence of tissue factor, with small fibrin(ogen)-binding aggregates still being formed (Figure 3). This reflects the presence of Src kinase-independent pathways of platelet aggregation. Pre-treatment of blood from FcR $\gamma$-chain null mice with PD173952 did not further reduce platelet adhesion.

Quantitative image analysis indicated that platelet deposition and PS exposure were significantly reduced by the various treatments (Figure 3). Pre-treatment of wildtype blood with the anti-GPVI Fab JAQ1 reduced total surface area coverage of platelets from $25.8 \%$ (control) to $6.3 \%$ and PS exposure from $7.9 \%$ (control) to $0.1 \%$ (Figure 3 ). This was also the case when using FcR $\gamma$-chain null blood or PD173952-treated blood, where platelet deposition was decreased to $3.8 \%$ and $4.9 \%$, and annexin A5 binding was even more reduced to $0.5 \%$ and $0.7 \%$, respectively (Figure 3 ). Reduced thrombus formation and coagulant activity under all above conditions was also seen at a lower shear rate of

\section{$1000 \mathrm{~s}^{-1}$}

\section{Tissue factor}

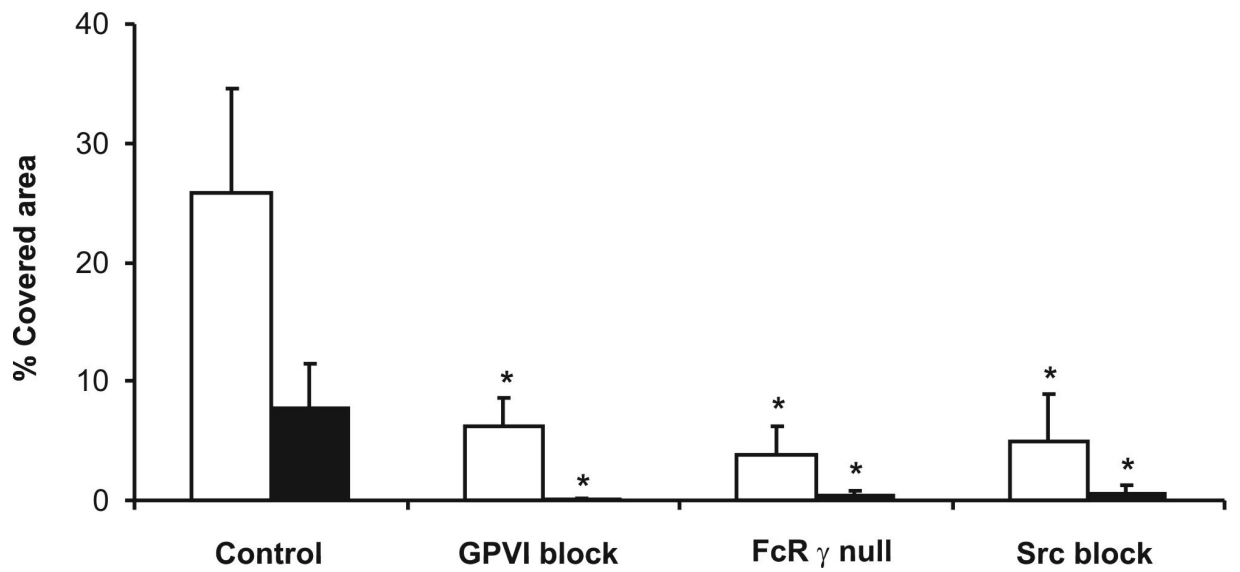

Figure $3 \mathrm{GPVI} / \mathrm{FcR} \gamma$-chain signaling pathway controls platelet deposition and procoagulant activity in blood triggered with tissue factor under flow. Citrate blood was perfused over collagen in the presence of tissue factor and $\mathrm{CaCl}_{2}$, as described for Figure 2. Post-perfusion was with AF647-labeled annexin A5. Data are percentages of area coverage of all platelets (white bars) or PS-exposing platelets (black bars). Mean $\pm S D(n=5)$; ${ }^{*} P \leq 0.05$ as compared to control. 
$150 \mathrm{~s}^{-1}$ (data not shown), which is representative of that in venules.

Together, these results stress the importance of the GPVI pathway in aggregate formation on collagen under flow. They also significantly extend earlier work by showing that, independently of the shear rate, GPVI signaling plays a key role in the coagulation process, i.e. in thrombin and fibrin formation triggered by tissue factor. Apparently, collagen-induced PS exposure via the FcR $\gamma$-chain is a key regulatory factor in coagulation.

\section{Components of the GPVI-PLC $\gamma 2$ signaling pathway involved in collagen-enhanced thrombin generation}

To investigate more directly how coagulation is controlled by collagen-GPVI interaction and subsequent signaling, we examined the effect of collagen on thrombin generation in mouse PRP triggered with tissue factor under static conditions. Addition of tissue factor/ $\mathrm{CaCl}_{2}$ to wildtype PRP resulted in high thrombin generation, a process which was greatly enhanced with a submaximal dose of collagen (peak level increased by $97 \%$, (Figure 4). Control experiments demonstrated that essentially no thrombin was formed during $60 \mathrm{~min}$, when platelets or tissue factor were absent (not shown). Collagen did not alter the thrombin generation curve with PRP from FcR $\gamma$-chain null mice (Figure 4). In agreement with this, in PRP from wildtype mice, blocking of GPVI (with JAQ1 Fab)

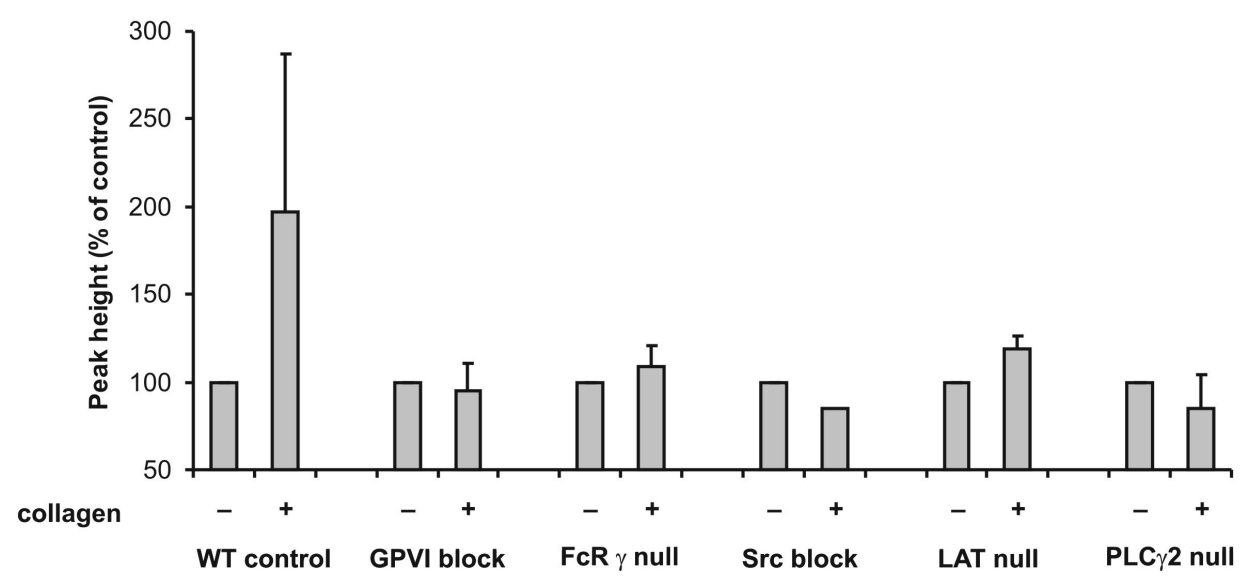

Figure 4 GPVI-PLC $\gamma 2$ signaling pathway mediates collagen-enhanced thrombin generation. Mouse PRP $\left(1 \times 10^{8}\right.$ platelets $/ \mathrm{mL}$, f.c.) was pre-incubated with vehicle (control), JAQ1 Fab (40 $\mu \mathrm{g} / \mathrm{mL}$ ) or Src kinase inhibitor, PD173952 (25 $\mu \mathrm{M})$. PRP was activated with vehicle (control) or 5 $\mu \mathrm{g} / \mathrm{mL}$ collagen, after which coagulation was initiated with tissue factor $(1 \mathrm{pM})$ and $\mathrm{CaCl}_{2}$. PRP $\left(1 \times 10^{8}\right.$ platelets $/ \mathrm{mL}$, f.c.) from mice deficient in FCR $\gamma$-chain, LAT or PLC $\gamma 2$, or from matched wildtype mice was similarly activated. Enhancing effect of collagen on thrombin peak height; peak height normalized to control condition or wildtype PRP (mean $\pm S D, n=4)$. 
or Src kinases (with PD173952) completely abolished the enhancing effect of collagen on thrombin generation. These interventions did not affect thrombin generation in PRP from FcR $\gamma$-chain null mice. In the absence of collagen, PRP from mice deficient in LAT or PLC $\gamma 2$ showed normal thrombin generation curves compared to wildtypes. Collagen addition did not increase the thrombin-generating activity in this PRP (Figure 4). Accordingly, the enhancing effect of collagen on thrombin generation was lost in case one of these components of the GPVI-PLC $\gamma 2$ signaling pathway was missing.

\section{Absence of GPVI signaling diminishes thrombus formation in venules and arterioles on exposed extracellular matrix}

To determine the physiological relevance of the collagen-induced activation pathway, we used an in vivo mouse model of microvascular thrombus formation that relies on exposure of the extracellular matrix and ensuing thrombin generation ${ }^{26}$. Injury of the mesenteric vessels of anesthetized mice was induced by topical application of $\mathrm{FeCl}_{3}$, which caused local, but complete denudation of the endothelium in venules and nearby arterioles. Intravital microscopy was used for real-time imaging of thrombus formation in the damaged vessels (Figure 5).

To study the involvement of GPVI, wildtype mice were injected with JAQ1 antibody, which causes biphasic, long-term in vivo depletion of GPVI on platelets, without affecting other platelet glycoproteins ${ }^{15,27}$. After $10 \mathrm{~min}$, this injection resulted in a

Wildtype

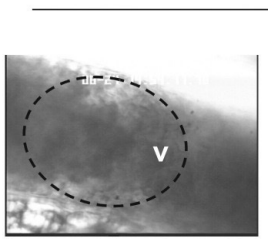

$4 \mathrm{sec}$

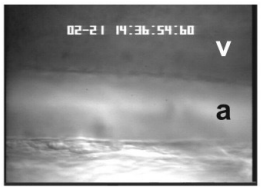

$4 \mathrm{sec}$

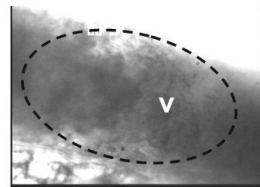

$20 \mathrm{sec}$

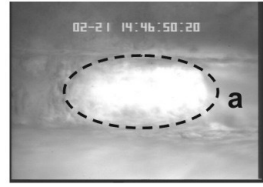

$10 \mathrm{~min}$

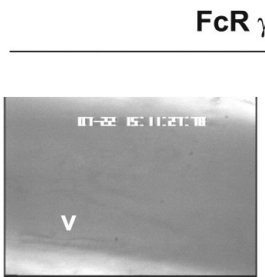

$4 \mathrm{sec}$

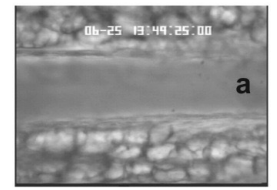

$4 \mathrm{sec}$

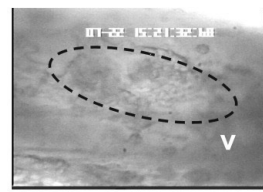

$10 \mathrm{~min}$

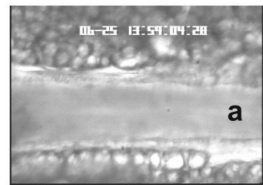

$10 \mathrm{~min}$

Figure 5 In vivo thrombus formation in venules and arterioles of wildtype and FcR $\gamma$-chain null mice. Thrombi were raised in vivo by application of $\mathrm{FeCl}_{3}$ on selected mesenterial venules (v) and arterioles (a) from wildtype or FcR $\gamma$-chain null mice. Shown are representative transillumination images $(280 \times 350 \mu \mathrm{m})$ from damaged venules and arterioles, captured at indicated times after $\mathrm{FeCl}_{3}$ application; thrombus area is indicated by dotted lines. 
greatly reduced platelet concentration ( $20 \%$ of normal platelet count) and a specific disappearance of GPVI on the platelet surface with other platelet glycoproteins remaining unchanged (not shown) ${ }^{15}$. At 5 days after injection, however, platelet count was normalized, while GPVI expression on platelets was still completely absent.

In venules from wildtype mice, thrombus formation started after seconds, while in arterioles there was a lagtime of several minutes. Thrombus size, quantified as thrombus height perpendicular to the vessel wall, increased with time in the vessels from wildtype mice. After $10 \mathrm{~min}, 39 \%$ and $31 \%$ of the venules and arterioles were occluded, respectively. When $\mathrm{FeCl}_{3}$ was applied to vessels from mice that were injected with JAQ1 antibody ( 5 days before), thrombus formation in both venules and arterioles was greatly delayed and reduced (Figure 6). Similarly, in FcR $\gamma$-chain null mice, thrombus formation induced by $\mathrm{FeCl}_{3}$ was markedly delayed in both venules and arterioles. Thrombi in this case remained small in size in venules, and were not formed at all in arterioles $(P \leq 0.05)$. No occlusion was observed within $10 \mathrm{~min}$. Furthermore, pre-injection of mice with $\mathrm{PD} 173952$ at $10 \mathrm{~min}$ before $\mathrm{FeCl}_{3}$ application (estimated final plasma concentration of $50 \mu \mathrm{M})$, resulted in a significant decrease in arterial thrombus size $(P \leq 0.05)$, but not in venular thrombus size (Figure 6). PD173952 injection caused full blockage of collageninduced aggregation in vitro. We conclude that, in this microvascular model of extracellular matrix exposure, the presence of GPVI, FcR $\gamma$ and Src kinase signaling are critical for venous and arterial thrombosis.
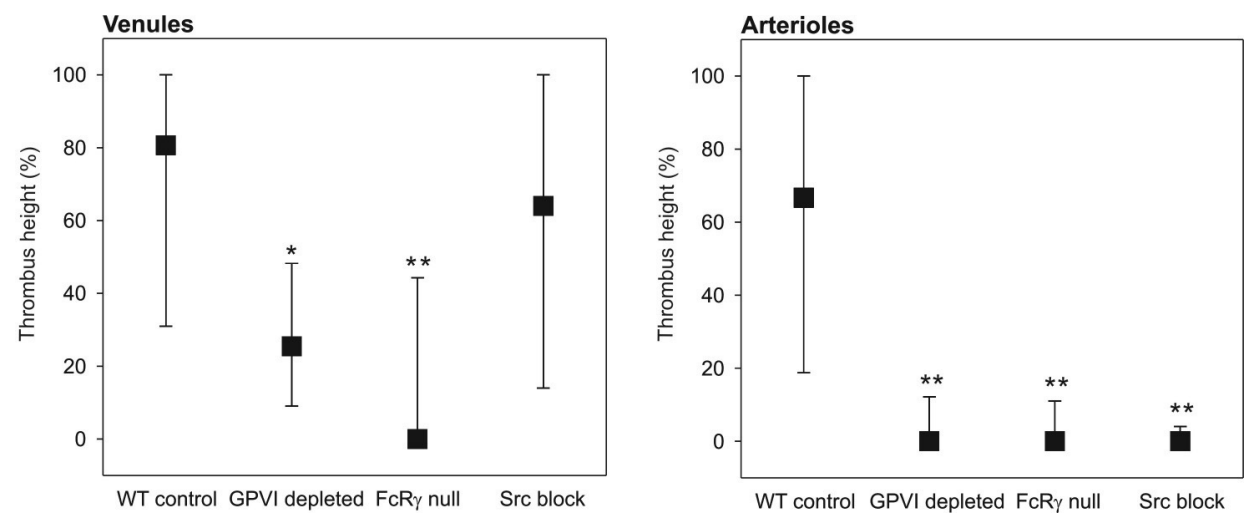

Figure 6 Reduced thrombus formation in arterioles and venules in the absence of GPVI signaling. Wildtype mice were pre-infused with saline vehicle (WT control) or Src kinase inhibitor PD173952 (100 $\mu \mathrm{L}$ of $1 \mathrm{mM}$ in saline) at $10 \mathrm{~min}$ before start. Other mice were injected with antiGPVI JAQ1 mAb (100 $\mu \mathrm{g}$ in saline) at 5 days before experimentation. Thrombi were raised by topical application of $\mathrm{FeCl}_{3}$ of adjacent mesenteric arterioles and venules. Thrombus size was measured at $10 \mathrm{~min}$ after $\mathrm{FeCl}_{3}$ application, and expressed as percentage of the local vessel diameter. Data are median values with interquartile ranges $(n=6) .{ }^{*} P \leq 0.1 ;{ }^{* *} P \leq 0.05$ compared to control. 


\section{Reduced fibrin formation and PS exposure in arterial thrombi after GPVI depletion}

TPLSM was used for better visualization of platelet activation and coagulation in arterioles after $\mathrm{FeCl}_{3}$ application. Wildtype mice were pre-injected with OG488-labeled fibrinogen or annexin $\mathrm{A} 5$, and fluorescent thrombi were subsequently scanned. In $\mathrm{FeCl}_{3}-$ treated arterioles from control mice, extensive deposition of OG488-fibrin(ogen) was detected and smaller spots of labeled annexin A5 (Figure 7). In contrast, in arterioles from mice pretreated with JAQ1 antibody (5 days) to down-regulate GPVI, $\mathrm{FeCl}_{3}$ application led to formation of only small domains of fibrin labeling and no annexin A5 labeling. Thus, both fibrin formation and PS exposure were reduced after downregulation of platelet GPVI.

\section{Discussion}

The present results indicate that the GPVI receptor, acting via a straightforward signaling pathway, acts as principal mediator of PS exposure, platelet-dependent thrombin generation and fibrin formation/coagulation in the presence of tissue factor. The signaling modules involved in the procoagulant platelet response are the FcR $\gamma$, Src

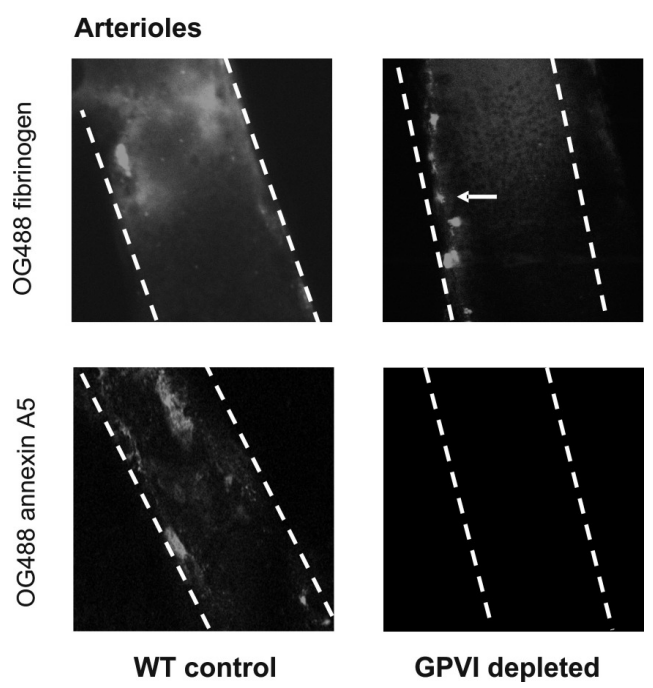

Figure 7 Decreased accumulation of fluorescent fibrin(ogen) and annexin A5 in arteriolar thrombi from GPVI-depleted mice. Wildtype mice were untreated (control) or depleted in GPVI by injection of $100 \mu \mathrm{g} \mathrm{JAQ} 1 \mathrm{mAb}$ at 5 days before start of experimentation. Prior to thrombus induction, mice were infused with either $200 \mu \mathrm{g}$ OG488-labeled fibrinogen or $200 \mu \mathrm{g} \mathrm{OG488-labeled} \mathrm{annexin} \mathrm{A5} \mathrm{in} 100 \mu \mathrm{l}$ saline. Mesenteric arterioles were exposed to $\mathrm{FeCl}_{3}$ for 10 min, after which fluorescence was observed in situ by TPLSM. Small fibrin clots were formed after GPVI depletion (arrow). Images $(206 \times 206 \mu \mathrm{m})$ are from representative damaged arterioles. 
kinases (likely Fyn/Lyn), the adaptor protein LAT and PLC $\gamma 2$, the latter of which is responsible for $\mathrm{Ca}^{2+}$ mobilization. In addition, we find that under flow this signaling pathway mediates the build-up of a platelet-fibrin thrombus. Evidence comes from a number of approaches to eliminate GPVI or subsequent activation steps. Blocking antiGPVI JAQ1 Fab fragments were used. Further, the Src kinase inhibitor, PD173952, which completely inhibits collagen-induced aggregation and tyrosine phosphorylation of mouse platelets in plasma, but leaves platelet responses to $G$ protein-coupled receptor agonists unchanged ${ }^{19}$. Abolished PS exposure and thrombus formation was also seen in blood from mice lacking either the FcR $\gamma$-chain, the adaptor protein LAT or the effector protein PLCY2. Especially the recognition that LAT is required for the procoagulant response is important, because earlier work suggested that LAT is dispensable for collagen- and convulxin-induced platelet aggregation ${ }^{28}$.

Interestingly, addition of JAQ1 antibody fragments resulted in lower platelet adhesion than with FcR $\gamma$-chain deficient blood. This can be explained by the recent observation that GPVI and GPIb-IX-V associate on platelets ${ }^{29}$; and the possibility that the JAQ1 antibody can thereby interfere with GPIb-mediated effects, while GPIb remains functionally active under flow in the absence of $\mathrm{FCR}^{30}$. We have shown before that GPIb plays a more prominent role in platelet-collagen interaction at reduced levels of GPVI and $\mathrm{FcR} \gamma$, which argues against a significant role of the FcR $\gamma$-chain in thrombus formation independently of GPVI, such as others have proposed ${ }^{31}$.

Earlier perfusion studies have indicated that platelet-collagen interaction via GPVI is the principal trigger of platelet activation and aggregation in mouse and human blood $^{5,15}$. Here, we significantly extend this observation by showing that GPVI signaling also controls thrombus formation on collagen in the presence of coagulation. We found that not only platelet aggregate formation, but also PS exposure and fibrin formation were greatly suppressed in blood from FcR $\gamma$-chain null mice, both at high (arteriolar) and low (venular) shear rates. This was also the case when GPVI or Src kinases were blocked with JAQ1 Fab or PD173952, respectively. During flow in the absence of GPVI activity, tissue factor was still active in triggering thrombin formation, as deduced from the traces of fibrin that still were formed, but apparently propagation of the coagulation process and fibrin clot formation were prevented. Accordingly, platelet activation by GPVI, most likely via PS exposure, is required for full coagulation activity.

In a macrovascular thrombosis model triggered by mechanical damage of the carotid artery, it has been demonstrated that GPVI is required for platelet adhesion to the vessel wall ${ }^{1}$. Whether or not coagulation contributes to the thrombotic process in that 
model is unknown. Here, we used a microvascular model, relying on free radical formation with $\mathrm{FeCl}_{3}$, known to be driven by thrombin formation and coagulation ${ }^{26}$. The application of $\mathrm{FeCl}_{3}$ resulted in almost complete disappearance of the endothelium in both arterioles and venules, causing exposure of the collagen-containing extracellular matrix (M. Kuijpers, unpublished data 2004). In either vessel type GPVI activity appeared to control the thrombus-forming process. For instance, in venules and arterioles from FcR $\gamma$-chain null mice, thrombi remained small in size (venules) or were not formed at all (arterioles). Long-term injection with anti-GPVI JAQ1 mAb, which completely downregulates GPVI on the platelet surface ${ }^{15}$, delayed and reduced the thrombus formation in venules and arterioles to a similar extent. Furthermore, observation with TPLSM indicated that in vessels from mice pre-injected with JAQ1 mAb only small spots of labeled fibrin were present, while labeled annexin A5 was not detectable at all. Finally, injection of PD173952 into mice to block (GPVI-activated) Src kinases suppressed the thrombotic process in arterioles.

Together, these data provide first in vivo evidence that GPVI, acting via a relatively simple signaling pathway (Src kinase, FcR $\gamma$, Syk, LAT, PLC $\gamma 2$ ) has a key role

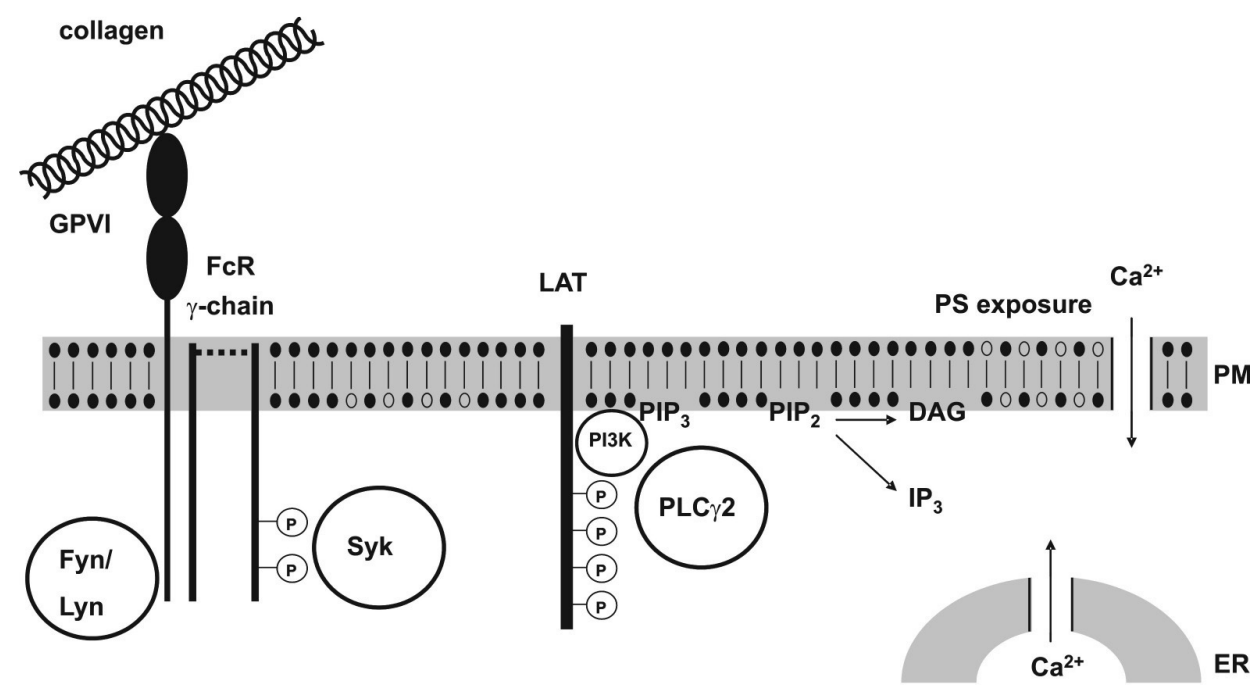

Src kinases $\longrightarrow$ Syk $\longrightarrow$ LAT $\longrightarrow$ PLC $\gamma 2 \longrightarrow \mathrm{Ca}^{2+} \longrightarrow$ PS exposure

Figure 8 GPVI signaling cascade. Crosslinking of GPVI induces tyrosine phosphorylation of the FCR $\gamma$-chain ITAM by the Src kinases, Fyn and Lyn. This initiates a Syk-dependent signaling cascade that leads to formation of a LAT complex and activation of PLC $\gamma 2$. PLC $\gamma 2$ associates directly with LAT, and with the membrane via binding of its PH domain to PIP3. PLC $\gamma 2$ activation causes $\mathrm{Ca}^{2+}$ mobilization as well as $\mathrm{Ca}^{2+}$ entry via plasma membrane channels, which subsequently leads to phosphatidylserine (PS) exposure. 
in platelet procoagulant activity and subsequent thrombin and fibrin formation. The procoagulant function of GPVI appears to contribute to arterial thrombus formation and, interestingly, also to venous thrombus formation. These findings thus point to a dual role of GPVI, both procoagulant and aggregatory, in collagen-induced thrombus formation in vivo.

\section{Acknowledgements}

We thank Pfizer Global Research and Development for supplying PD173952. This work was supported by the Netherlands Heart Foundation (2002B014) and the Netherlands Organization for Scientific Research (902-16-276). AS and JA were supported by a Marie Curie fellowship from the European Community (QLK5-CT-200060007). JA holds a BHF Studentship.

\section{References}

1. Massberg S, Gawaz M, Grüner S, Schulte V, Konrad I, Zohlnhofer D, Heinzmann U, Nieswandt B. A crucial role of glycoprotein VI for platelet recruitment to the injured arterial wall in vivo. J Exp Med. 2003;197:41-49.

2. Butenas S, Cawthern KM, van 't Veer C, Dilorenzo ME, Lock JB, Mann KG. Antiplatelet agents in tissue factor-induced blood coagulation. Blood. 2001;97:2314-2322.

3. Nieswandt B, Brakebusch C, Bergmeier W, Schulte V, Bouvard D, Mohtari-Nejad R, Lindhout T, Heemskerk JWM, Zirngibl H, Fässler R. Glycoprotein VI but not $\alpha 2 \beta 1$ integrin is essential for platelet interaction with collagen. EMBO J. 2001;20:2120-2130.

4. Kuijpers MJE, Schulte V, Bergmeier W, Lindhout T, Brakebusch C, Offermanns S, Fässler R, Heemskerk JWM, Nieswandt B. Complementary roles of glycoprotein VI and $\alpha 2 \beta 1$ integrin in collagen-induced thrombus formation in flowing whole blood ex vivo. FASEB J. 2003;17:685687.

5. Siljander PRM, Munnix ICA, Smethurst PA, Deckmyn H, Lindhout T, Ouwehand WH, Farndale RW, Heemskerk JWM. Platelet receptor interplay regulates collagen-induced thrombus formation in flowing human blood. Blood. 2004;103:1333-1341.

6. Heemskerk JWM, Kuijpers MJE, Munnix ICA, Siljander PRM. Platelet collagen receptors and coagulation. Trends Cardiovasc Med. 2005;15:86-92.

7. Zwaal RFA, Schroit AJ. Pathophysiological implications of membrane phospholipid asymmetry in blood cells. Blood. 1997;89:1121-1132.

8. Monroe DM, Hoffman M, Roberts HR. Platelets and thrombin generation. Arterioscler Thromb Vasc Biol. 2002;22:1381-1389.

9. Nieswandt B, Bergmeier W, Schulte V, Rackebrandt K, Gessner JE, Zirngibl H. Expression and function of the mouse collagen receptor glycoprotein VI is strictly dependent on its association with the FcR $\gamma$ chain. J Biol Chem. 2000;275:23998-234002.

10. Ezumi Y, Shindoh K, Tsuji M, Takayama H. Physical and functional association of the Src family kinases Fyn and Lyn with the collagen receptor glycoprotein VI-Fc receptor $\gamma$-chain complex on human platelets. J Exp Med. 1998;188:267-276.

11. Watson SP. Collagen receptor signaling in platelets and megakaryocytes. Thromb Haemost. 1999;82:365-376. 
12. Nieswandt B, Watson SP. Platelet-collagen interaction: is GPVI the central receptor? Blood. 2003;102:449-461.

13. Wonerow P, Pearce AC, Vaux DJ, Watson SP. A critical role for phospholipase $C \gamma 2$ in $\alpha$ llb $\beta 3$ mediated platelet spreading. J Biol Chem. 2003;278:37520-37529.

14. Heemskerk JWM, Bevers EM, Lindhout T. Platelet activation and blood coagulation. Thromb Haemost. 2002;88:186-193.

15. Nieswandt B, Schulte V, Bergmeier W, Mokhtari-Nejad R, Rackebrandt K, Cazenave JP, Ohlmann P, Gachet C, Zirngibl H. Long-term antithrombotic protection by in vivo depletion of platelet glycoprotein VI in mice. J Exp Med. 2001;193:459-469.

16. Ni H, Papalia JM, Degen JL, Wagner DD. Control of thrombus embolization and fibronectin internalization by integrin $\alpha$ llb $\beta 3$ engagement of the fibrinogen- $\gamma$ chain. Blood. 2003;102:3609-3614.

17. Wang D, Feng J, Wen R, Marine JC, Sangster MY, Parganas E, Hoffmeyer A, Jackson CW, Cleveland JL, Murray PJ, Ihle JN. Phopholipase $\mathrm{C} \gamma 2$ is essential in the functions of B cell and several Fc receptors. Immunity. 2000;13:25-35.

18. Zhang W, Irvin BJ, Trible RP, Abraham RT, Samelson LE. Functional analysis of LAT in TCRmediated signaling pathways using a LAT-deficient Jurkat cell line. Int Immunol. 1999;11:943950.

19. Auger JM, Kuijpers MJE, Senis YA, Watson SP, Heemskerk JWM. Adhesion of human and mouse platelets to collagen under shear. FASEB J. 2005;19:825-827.

20. Van Zandvoort M, Engels W, Douma K, Beckers L, oude Egbrink M, Daemen M, Slaaf DW. Two-photon microscopy for imaging of the (atherosclerotic) vascular wall. J Vasc Res. 2004;41:54-63.

21. Hemker HC, Giesen P, Al Dieri R, Regnault V, de Smedt E, Wagenvoord R, Lecompte T, Béguin S. Calibrated automated thrombin generation measurement in clotting plasma. Pathophysiol Haemost Thromb. 2003;33:4-15.

22. Vanschoonbeek K, Feijge MAH, van Kampen RJW, Kenis H, Hemker HC, Giesen PLA, Heemskerk JWM. Initiating and potentiating roles of platelets in tissue factor-induced thrombin generation in the presence of plasma. J Thromb Haemost. 2004;2:476-484.

23. Van Gestel M, Heemskerk JWM, Slaaf DW, Heijnen VVT, Sage SO, Reneman RS, oude Egbrink MGA. Real-time detection of activation patterns in individual platelets during thromboembolism in vivo. J Vasc Res. 2002;39:534-543.

24. Lecut C, Schoolmeester A, Kuijpers MJE, Broers JLV, van Zandvoort MAMJ, Vanhoorelbeke $\mathrm{K}$, Deckmyn H, Jandrot-Perrus M, Heemskerk JWM. Principal role of glycoprotein VI in $\alpha 2 \beta 1$ and $\alpha \mathrm{llb} \beta 3$ activation during collagen-induced thrombus formation. Arterioscler Thromb Vasc Biol. 2004;24:1727-1733.

25. Kuijpers MJE, Nieuwenhuys CMA, Feijge MAH, Giesen PLA, oude Egbrink MGA, Heemskerk JWM. Regulation of tissue factor-induced coagulation and platelet aggregation in flowing whole blood. Thromb Haemost. 2005;93:97-105.

26. Ni H, Denis CV, Subbarao S, Degen JL, Sato TN, Hynes RO, Wagner DD. Persistence of platelet thrombus formation in arterioles of mice lacking both von Willebrand factor and fibrinogen. J Clin Invest. 2000;106:385-392.

27. Schulte V, Rabie T, Prostredna M, Aktas B, Grüner S, Nieswandt B. Targeting of the collagen-binding site on glycoprotein $\mathrm{VI}$ is not essential for in vivo depletion of the receptor. Blood. 2003;101:3948-3952.

28. Judd BA, Myung PS, Obergfell A, Myers EE, Cheng AM, Watson SP, Pear WS, Allman D, Shattil SJ, Koretzky GA. Differential requirement for LAT and SLP-76 in GPVI versus T cell receptor signaling. J Exp Med. 2002;195:705-717.

29. Arthur JF, Gardiner EE, Matzaris M, Taylor SG, Wijeyewickrema L, Ozaki Y, Kahn M, Andrews R, Berndt MC. Glycoprotein VI is associated with GPIb-IX-V on the membrane of resting and activated platelets. Thromb Haemost. 2005;93:716-723. 
30. Kuijpers MJE, Schulte V, Oury C, Lindhout T, Broers J, Hoylaerts MF, Nieswandt B, Heemskerk JWM. Facilitating roles of murine platelet glycoprotein $\mathrm{lb}$ and $\alpha \mathrm{llb} \beta 3$ in phosphatidylserine exposure during vWF-collagen-induced thrombus formation. J Physiol. 2004;558:403-415.

31. Liu J, Pestina TI, Berndt MC, Jackson CW, Gartner TK. Botrocetin/vWf-induced signaling through GPIb-IX-V produces $\mathrm{TXA}_{2}$ in an $\alpha$ llb $\beta 3$ and aggregation-independent manner. Blood. 2005;106:2750-2756. 


\section{Chapter 6}

\section{Key role of platelet procoagulant activity}

in tissue-factor- and collagen-induced thrombus formation in arteries and veins in vivo

Marijke, E. J. Kuijpers ${ }^{\star}$, Imke C. A. Munnix ${ }^{\star}$, Judith M. E. M. Cosemans, Bart J. M. van Vlijmen, Chris P. M. Reutelingsperger, Mirjam G. A. oude Egbrink and Johan W. M. Heemskerk

Submitted for publication 


\begin{abstract}
Blood coagulation and platelet activation are mutually dependent processes, but contribute with different extent to venous and arterial thrombosis. The processes of platelet activation and thrombin generation have been extensively studied in vitro, but the precise interactions between these processes are unclear in vivo. We investigated the interplay of platelet activation and coagulation in a mouse model of both arterial and venous thrombosis. Thrombus formation was studied in vivo by topical application of $\mathrm{FeCl}_{3}$ on mouse mesenteric vessels. Both in arteries and veins, the thrombotic process relied on tissue factor-factor VII(a) interaction and collagen exposure, followed by glycoprotein VI-mediated platelet activation. Mild thrombin inhibition or platelet inhibition suppressed arterial thrombus formation, while strong thrombin inhibition or mild thrombin inhibition in combination with platelet inhibition was necessary to suppress venous thrombosis. Thrombus formation in both vessel types was characterized by the presence of phosphatidylserine (PS)-exposing platelets, detected with fluorescently labeled annexin A5. Shielding of exposed PS by injected annexin A5 abolished formation of both arterial and venous thrombi, while mutant M1234-annexin A5 was ineffective. Decreased anticoagulant activity by using mice carrying the factor $\vee$ Leiden mutation had only little effect. In this microvascular model of combined tissue factor/collagen-induced thrombosis, propagation of thrombin generation by PS-exposing platelets is a key regulatory process in the formation of thrombi. Platelet-dependent thrombin generation is most active in venous thrombus formation and may be a clinically relevant target to reduce thrombosis.
\end{abstract}

\title{
Introduction
}

Cardiovascular disease is still the leading cause of death in Western countries. Current understanding is that pathological thrombosis in veins and arteries is caused by the interplay between activated platelets and the coagulation system. However, these two processes contribute differently to either arterial or venous thrombus formation. Thrombi formed in the venous system are mostly rich in fibrin and trapped red cells, though relatively poor in platelets. This is in paradox with the fact the thrombin is one of the most potent platelet agonists ${ }^{1}$, which implicates that platelets must become activated by thrombin in thrombotic veins. On the other hand, arterial thrombosis is associated with undesired platelet activation. 'White' thrombi formed in atherothrombotic arteries are rich in aggregated platelets, although fibrin is detectable here as well. This is in agreement with the fact that -in clinical practice- anticoagulant drugs such as heparins and active- 
site thrombin inhibitors are preferentially used to reduce venous thromboembolism, while platelet inhibition is preferred in case of arterial thrombosis. Intriguingly, recent in vivo experiments, using several animal thrombosis models, have shown that thrombin is also a key regulator of thrombus formation in arteries ${ }^{1-5}$. How this finding relates to the assumed more predominant role of thrombin in venous thrombosis is unclear.

In vitro studies on the regulation of thrombin generation in platelet-rich plasma (PRP) have clearly shown that platelet inhibition, e.g. with cAMP-elevating agents or integrin $\alpha$ llb $\beta 3$ antagonists, have an anticoagulant action by slowing down the formation of thrombin and fibrin ${ }^{6,7}$. Although there is evidence that (activated) platelets stimulate the coagulation process ${ }^{8,9}$, the mechanism behind this effect is disputed. Studies in vitro have pointed to specific binding of coagulation factors (prothrombin and factors $V, X$ and $\mathrm{XI})$ to integrins and other receptor proteins on platelets ${ }^{10,11}$. The binding of activated factor $V$ is of interest, as platelets are supposed to play a role in the inactivation of factor $\mathrm{Va}$ by activated protein $\mathrm{C}^{12}$. Also, tissue factor can bind to platelet aggregates and thrombi, and then stimulate the coagulation process ${ }^{2}$. Another proposed mechanism concerns the exposure of procoagulant phosphatidylserine (PS) at the outer surface of activated platelets. At least in vitro, PS serves as a site for the assembly of coagulation factor complexes that greatly enhance thrombin generation ${ }^{13}$. A strong trigger of PS exposure is platelet interaction with immobilized collagen, mediated by glycoprotein $\mathrm{VI}$ $(\mathrm{GPVI})^{14,15}$, while platelet stimulation via thrombin receptors is less effective ${ }^{16}$. Whether and how these platelet-dependent processes indeed contribute to pathological thrombus formation in arteries and veins in vivo is poorly understood.

In the present study the importance and the mechanism of platelet-dependent coagulation was investigated in arterial and venous thrombosis. We used an established murine thrombosis model of $\mathrm{FeCl}_{3}$-induced vascular damage, known to be sensitive to both platelet and thrombin inhibition ${ }^{1,4,17-19}$. The data show that thrombin and PSexposing platelets play prominent, but different roles in the thrombotic process in arteries and veins. This platelet procoagulant response may constitute an attractive novel target for antithrombotic therapies.

\section{Materials and Methods}

\section{Animals}

C57BI/6 mice of 4-5 weeks old (11-21 g) or 12 weeks old $(20-25 \mathrm{~g})$ of either sex were obtained from Charles River (Maastricht, the Netherlands). Mice deficient in FcR $\gamma$ - 
chain of the same age and background were from Taconics (Germantown, NY, USA) ${ }^{20}$. Mice carrying the Factor $V$ Leiden mutation (Arg 504 to Gln) were described previously ${ }^{21}$. Factor V R504Q mice were backcrossed to C57BL/6J mice (Jackson Labs, Bar Harbor, $\mathrm{ME}$ ) for at least 8 generations (N8), and N8 heterozygous mice were intercrossed to produce homozygous $\left(\mathrm{FV}^{\mathrm{Q} / \mathrm{Q}}\right)$, heterozygous $\left(\mathrm{FV}^{\mathrm{Q} /+}\right)$, and wildtype offspring $\left(\mathrm{FV}^{+/+}\right)$. The $\mathrm{FV}^{\mathrm{Q} / \mathrm{Q}}$ and $\mathrm{FV}^{+/+}$were intercrossed to produce the $\mathrm{FV}^{\mathrm{Q} / \mathrm{Q}}$ and $\mathrm{FV}^{+/+}$littermates used in the present study. Genotyping for Factor $V$ Leiden was performed by PCR analysis of tail DNA with the primers previously described ${ }^{21}$. Local animal care and use committees approved the experiments.

\section{Materials}

Fibrillar Horm collagen (type-I) was purchased from Nycomed Pharma (Munich, Germany). Unfractionated heparin (ISH 1), prostaglandin $E_{1}$ and rhodamin $6 G$ were from Sigma (St. Louis, MO, USA). Annexin A5, unlabeled and labeled with fluorescein isothiocyanate (FITC), and M1234-annexin A5 were from Nexins Research (Hoeven, the Netherlands); acridine red came from Chroma (Stuttgart, Germany). Recombinant human tissue factor was from Dade (Düdingen, Switzerland); Z-Gly-Gly-Arg aminomethyl coumarin (Z-GGR-AMC) and Gly-Pro-Arg-Pro (GPRP, Pefablock) were from Bachem (Bubendorf, Switzerland); $\mathrm{FeCl}_{3}$ was from Merck (Darmstadt, Germany). Hematoxylin and eosin came from Klinipath (Duiven, the Netherlands). Ketamine and xylazine were from Eurovet (Bladel, the Netherlands). Transfected cells expressing cDNA encoding for the annexin A5 mutant M1234 were provided by dr. F. Russo-Marie (BionexinsPharmaceuticals, France). Melagatran was kindly provided by dr. M. Elg (AstraZeneca, Mölndal, Sweden). Mouse tissue factor, anti-mouse tissue factor antibody and mouse factor VIlai (active site-inhibited factor seven, ASIS) ${ }^{22}$ were kindly provided by dr. P. Tijburg (Novo Nordisk, Bagsværd, Denmark).

\section{Perfusion of whole blood under coagulant conditions}

Collagen- and tissue factor-induced thrombus formation under coagulant and flow conditions was measured as described ${ }^{23}$. Briefly, mice were bled retro-orbitally, and blood (9 volumes) was collected in $0.129 \mathrm{M}$ citrate (1 volume). The blood was supplemented with FITC-labeled annexin A5 $(0.5 \mu \mathrm{g} / \mathrm{ml})$ and perfused through a parallelplate transparent flow chamber that contained a coverslip coated with collagen. Coagulation was introduced by co-perfusion with 0.1 volume of $\mathrm{CaCl}_{2}(200 \mathrm{mM})$ and 
tissue factor (20 pM). Final wall shear rate was $1000 \mathrm{~s}^{-1}$. Recording of bright-field and fluorescent images was performed with a non-confocal microscopic imaging system.

\section{Thrombus formation in vivo}

Four- to 5-week-old mice were subjected to $\mathrm{FeCl}_{3}$-induced thrombus formation in mesenteric blood vessels as described ${ }^{23}$. Topical application of $\mathrm{FeCl}_{3}(30 \mu \mathrm{L}, 500 \mathrm{mM})$ damaged the vessel wall of selected arteries and veins. At baseline, the wildtype arteries had a diameter of $68 \pm 4 \mu \mathrm{m}(n=30)$, while the venous diameter was $107 \pm 8 \mu \mathrm{m}(n=20)$. Diameters of the vessels monitored in genetically modified animals were not different (not shown). An intravital microscopic imaging system allowed continuous recording of thrombus formation in arteries and veins for at least 10 minutes (min). For each vessel, the following parameters were quantified from video recordings off-line: lag-time to first observation of thrombus formation, thrombus height perpendicular to the vessel wall (expressed relative to the local vessel diameter) at 2, 5 and $10 \mathrm{~min}$ after $\mathrm{FeCl}_{3}$ application, and time to occlusion.

Where indicated, inhibitors were injected intravenously (bolus, $100 \mu \mathrm{l}$ ) at 5-10 min before application of $\mathrm{FeCl}_{3}$. Control mice received the same volume of saline (vehicle). Injection of FITC-labeled annexin A5 $(0.16 \mu \mathrm{g} / \mathrm{g}$ body weight (bw)) shortly after $\mathrm{FeCl}_{3}$ application, visualized PS exposure in vivo. Epi-illumination with a Xenon lamp using a sensitive, high-resolution fluorescence imaging system and an intensified CCD camera (Photonic Sciences), enabled capture of high-resolution fluorescence images as described ${ }^{24}$. Centerline blood flow velocities $(v)$ of labeled leukocytes were measured in 8 arteries and 8 veins after injection of rhodamin $6 \mathrm{G}(30 \mu \mathrm{l}, 1 \mathrm{mg} / \mathrm{ml}$; i.v.). This was converted to wall shear rates $(r)$ according to the Newtonian equation, $r=8 \times(v / 1.6) /$ vessel diameter.

\section{Thrombin generation measurements}

Murine platelet-poor plasma (PPP) or PRP was prepared from blood from 12 week old mice ${ }^{25}$. Thrombin generation was measured using the thrombogram method ${ }^{26}$, adapted for murine plasma. Normalized PRP $\left(1.5 \times 10^{8}\right.$ platelets $\left./ \mathrm{ml}\right)$ or PPP supplemented with $4.0 \mu \mathrm{M}$ phospholipid vesicles of phosphatidylserine : phosphatidylcholine : phosphatidylethanolamine $(1: 3: 1, \mathrm{~mol} / \mathrm{mol})$ was used. Plasmas were preincubated with inhibitors for $10 \mathrm{~min}$ at room temperature, and subsequently added to a 96-well plate, containing tissue factor (1 pM, final concentration) in Hepes buffer (20 mM Hepes, $140 \mathrm{mM} \mathrm{NaCl}, 5 \mathrm{mg} / \mathrm{ml}$ bovine serum albumin, $\mathrm{pH}$ 7.35). 
Thrombin formation was started by addition of $\mathrm{CaCl}_{2}(16.6 \mathrm{mM})$ and Z-GGR-AMC (2.5 $\mathrm{mM}$ ) in Hepes buffer. Fluorescence was continuously measured in time at $37^{\circ} \mathrm{C}$ with a Fluoroscan Ascent well-plate reader (Thermolab Systems). First-derivative curves of accumulation of fluorescence were generated as described ${ }^{27}$. Assays were run in duplicates or triplicates; calibrations were performed with human thrombin. Effects on peak height of thrombin generation curves (maximal levels) were measured, which parameter is proportional to the maximal rate of thrombin generation.

\section{Statistical analysis}

Data are presented as means \pm SEM. Differences between experimental groups were tested with the Mann-Whitney $U$ test, using the statistical package for social sciences (SPSS 11.0).

\section{Results}

Interaction between tissue factor-induced thrombin formation and platelet phosphatidylserine exposure in blood flowing over collagen

The importance of interactions between platelet activation and coagulation in thrombus formation under flow was evaluated with mouse blood. Thrombin generation was triggered by co-infusion of citrate-anticoagulated blood with a low dose of tissue factor (2 $\mathrm{pM}$ ) in the presence of $\mathrm{CaCl}_{2}$, directly before entering a collagen-containing flow chamber. At an arterial shear rate of $1,000 \mathrm{~s}^{-1}$, this resulted in early platelet deposition, subsequent aggregate formation and appearance of fibrin fibers after 2-3 min. At a more advanced stage (7-8 $\mathrm{min}$ ), the chamber occluded with large fibrin-platelet thrombi and trapped red cells (Figure 1A). Labeling of the blood with FITC-annexin A5 $(0.5 \mu \mathrm{g} / \mathrm{ml}$, a low dose not influencing coagulation) indicated that many of the platelets on collagen and on aggregates exposed PS, covering about $20 \%$ of the surface area (Figure 1B). In the presence of melagatran $(10 \mu \mathrm{M})$, a high affinity, active-site thrombin inhibitor ${ }^{28}$, aggregate formation still occurred, but fibrin fibers and occlusive thrombi did not form (Figure $1 \mathrm{C}$ ). In this case, only collagen-bound platelets exposed PS, covering $5 \%$ of the surface area (Figure 1D). Quantitative analysis indicated that this melagatran concentration markedly but incompletely delayed and reduced the appearance of PSexposing platelets during the flow experiment (Figure 1E), while at the same time it suppressed thrombin generation in PRP by $95 \pm 2 \%$ (mean \pm SEM, $n=3$ ). Thus, under these high shear flow conditions, melagatran suppressed the formation of PS-expressing 120 
platelets in parallel with the formation of platelet-fibrin clots. Previously, using anticoagulated murine blood, we have shown that the (remaining) platelet aggregate formation and PS exposure results from collagen-induced GPVI activation ${ }^{25}$. Together with the present results, this indicates that the processes of GPVI-induced platelet activation and coagulation activation cooperate in generating procoagulant platelets.

\section{Tissue factor and collagen trigger thrombus formation in arteries and veins}

To investigate the role of procoagulant platelets in arterial and venous thrombus formation in vivo, we used a $\mathrm{FeCl}_{3}$ model of thrombosis induction in wildtype mouse mesenteric vessels, as described earlier ${ }^{23}$. Wall shear rates in the mesenteric arteries and veins were $1183 \pm 187(n=8)$ and $344 \pm 77 \mathrm{~s}^{-1}(n=8)$, respectively. Topical application of $\mathrm{FeCl}_{3}$ resulted in damage of adjacent mesenteric arteries and veins. Histochemical staining indicated that in both vessel types the endothelial layer completely disappeared after $\mathrm{FeCl}_{3}$ treatment, while the vascular structure remained intact (not shown). Real-time visualization by intravital microscopy showed that $\mathrm{FeCl}_{3}$

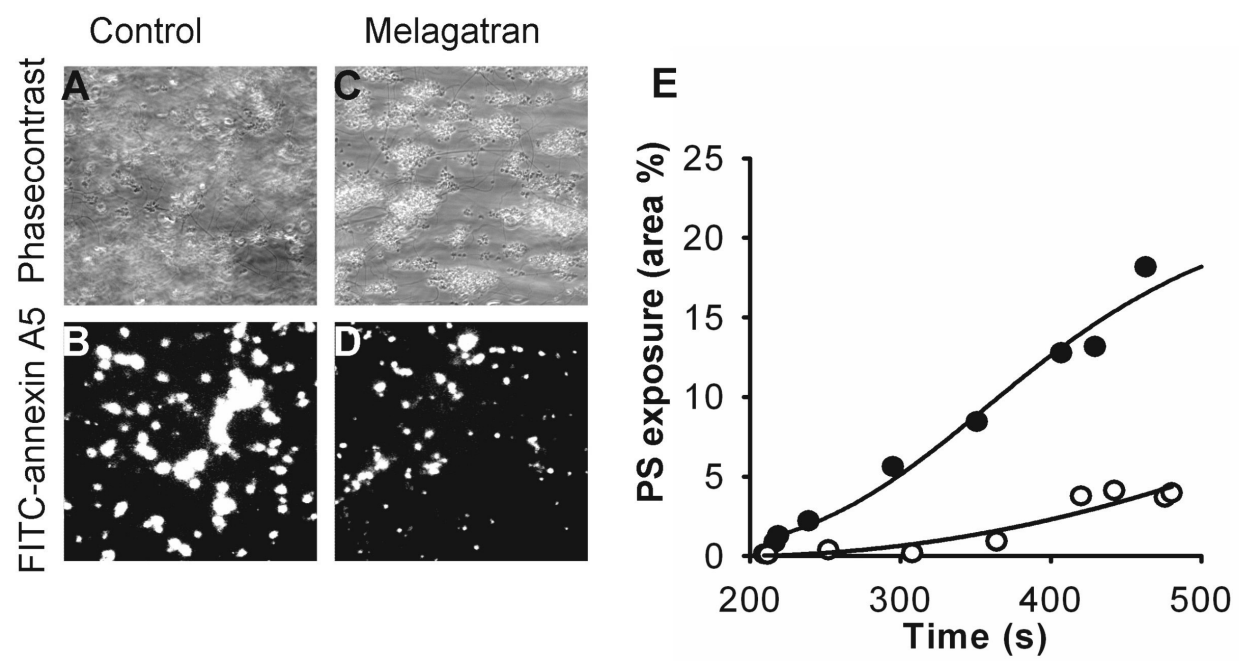

Figure 1 Role of procoagulant platelets in collagen- and tissue factor-induced thrombus formation under shear. Citrated mouse blood was perfused for 4 min over a collagen surface at a shear rate of $1,000 \mathrm{~s}^{-1}$. During perfusion, coagulation was triggered with $2 \mathrm{pM}$ tissue factor and $20 \mathrm{mM}$ $\mathrm{CaCl}_{2}$ (resulting in about $2 \mathrm{mM}$ free $\mathrm{Ca}^{2+}$ ) in the absence $(\mathrm{A}, \mathrm{B})$ or presence $(C, D)$ of $10 \mu \mathrm{M}$ melagatran. Shown are representative phase-contrast images $(A, C)$ and fluorescence images of PSexposing platelets $(B, D)$, taken at 4 min after perfusion of blood labeled with $0.5 \mu \mathrm{g} / \mathrm{ml}$ FITC-annexin A5 $(n=3)$. (E) Inhibitory effect of melagatran on PS exposure under flow. Surface area coverage with fluorescence is given during perfusion with blood labeled with $0.5 \mu \mathrm{g} / \mathrm{ml}$ FITC-annexin A5 and triggered with tissue factor/ $\mathrm{CaCl}_{2}$. Control condition $(\bullet)$, melagatran condition $(\mathrm{o})(\mathrm{n}=3)$. 
caused rapid adhesion of platelets in veins, followed by formation of thrombi, while these processes started only after several minutes in arteries (Figure 2A). Under these control conditions, thrombus formation was progressive in both vessel types (Figure 2B). At 10 min after $\mathrm{FeCl}_{3}$ application, $33 \%$ of the arteries and $42 \%$ of the veins were fully occluded.

To establish the involvement of tissue factor in this thrombosis model, we inhibited tissue factor activity or, alternatively, its ligand factor VII(a) in wildtype mice. Intravenous administration of anti-murine tissue factor antibody ( $3 \mu \mathrm{g} / \mathrm{g} \mathrm{bw}$ ) significantly delayed (Figure 2A) and reduced (Figure 2B) the thrombotic process in both arteries and veins. Injection of mouse active site-inhibited factor VII (factor VIlai, $10 \mu \mathrm{g} / \mathrm{g} \mathrm{bw}$ ) had similar inhibitory effects (Figure 2). Ex vivo experiments, using plasma samples from mice injected with factor VIlai, showed that tissue factor-induced (1 pM) thrombin generation was severely delayed and reduced to $6.8 \pm 2.4 \%$ of control level $(n=3)$. In

A

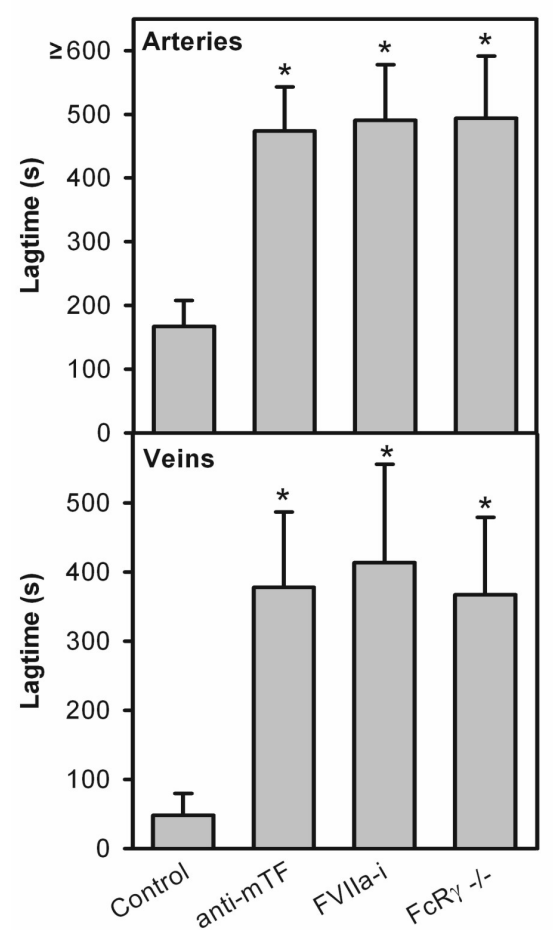

B

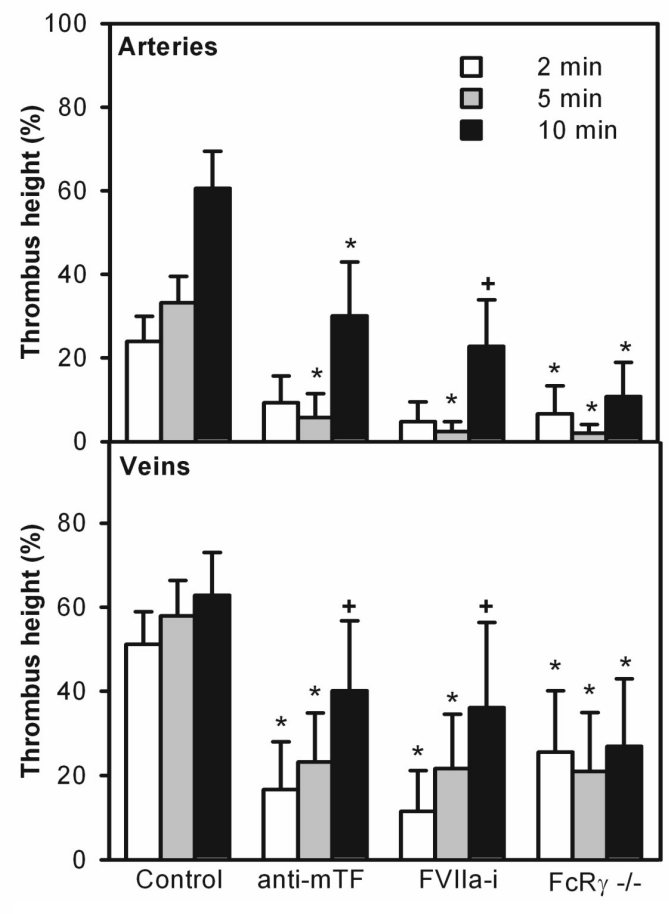

Figure 2 Complementary contribution of tissue factor and collagen in $\mathrm{FeCl}_{3}$-induced thrombus formation in mesenteric arteries and veins in vivo. Wildtype mice were injected intravenously with vehicle (control), $3 \mu \mathrm{g} / \mathrm{g}$ bw anti-mouse tissue factor antibody (anti-mTF) or $10 \mu \mathrm{g} / \mathrm{g}$ bw factor VIlai (FVIlai). Mesenteric vessels of wildtype and FcR $\gamma$-chain -/- mice were damaged by topical application of $\mathrm{FeCl}_{3}$. (A) Lag-time to thrombus formation after $\mathrm{FeCl}_{3}$ application. (B) Thrombus height measured at indicated times after $\mathrm{FeCl}_{3}$ application (\% of vessel diameter). Data are means $\pm \mathrm{SEM}(\mathrm{n}=6-12)$. ${ }^{*} p<0.05 ;{ }^{+} p<0.1$ compared to control. 
vitro experiments confirmed that anti-tissue factor antibody or factor VIlai (each $20 \mu \mathrm{g} / \mathrm{ml}$ ) blocked thrombin generation in mouse plasma by $>85 \%$. To demonstrate the involvement of platelet-collagen interaction in this model, we used mice deficient in the FcR $\gamma$-chain, whose platelets do not express the GPVI collagen receptor ${ }^{29}$. In comparison to wildtypes, application of $\mathrm{FeCl}_{3}$ resulted in a greatly delayed and reduced thrombus buildup in both arteries and veins (Figure 2). Earlier results show that injection of wildtype mice with inhibitory anti-GPVI antibody JAQ1 also suppresses thrombus formation in these arteries ${ }^{23}$. We therefore conclude that, in this model, the thrombotic process is regulated by both coagulation activation by exposed tissue factor/factor VII(a) and interaction of collagen with platelets. Interestingly, the role of tissue factor in this process was similar in arterial and venous thrombus formation.

\section{Stronger inhibition of thrombin is required to affect thrombus formation in veins}

To investigate how thrombin generation and coagulation drive the thrombotic process in arteries and veins, wildtype mice were injected with a moderate or higher dose of melagatran ( 0.175 or $0.5 \mu \mathrm{g} / \mathrm{g}$ bw, respectively). Ex vivo analysis indicated that these doses gave 3-fold and higher prolongation in clotting times (see also below). In comparison to control mice, injected with saline vehicle, injection of $0.175 \mu \mathrm{g} / \mathrm{g} \mathrm{bw}$ melagatran did not influence the lag-time to thrombus formation in arteries (Figure $3 \mathrm{~A}$ ), but thrombus height was significantly reduced (Figure 3B). After administration of the higher melagatran dose $(0.5 \mu \mathrm{g} / \mathrm{g} \mathrm{bw})$, the arterial lag-time to thrombus formation was prolonged to $514 \pm 86 \mathrm{~s}$ (mean \pm SEM, $n=7$, Figure $3 \mathrm{~A}$ ), while thrombus build-up was again greatly reduced (Figure $3 \mathrm{~B}$ ). Strikingly, venous thrombus formation was inhibited only by the higher dose of melagatran (Figure 3A, B). None of the veins occluded within $10 \mathrm{~min}$ with the moderate or high dose of melagatran. Similar observations were made after injection of $0.05 \mathrm{U} / \mathrm{g}$ bw unfractionated heparin, an indirect thrombin inhibitor. This only inhibited thrombus formation in arteries $(p<0.05)$, but not significantly in veins (not shown).

Plasma samples were obtained from blood collected after 30 min of melagatran administration. The thrombogram method was used to determine the activity of melagatran in ex vivo mouse plasma and indicated that thrombin peak height was diminished to $18 \%$ and $4 \%$ of control, respectively (Figure $3 \mathrm{C}$ ). 
A
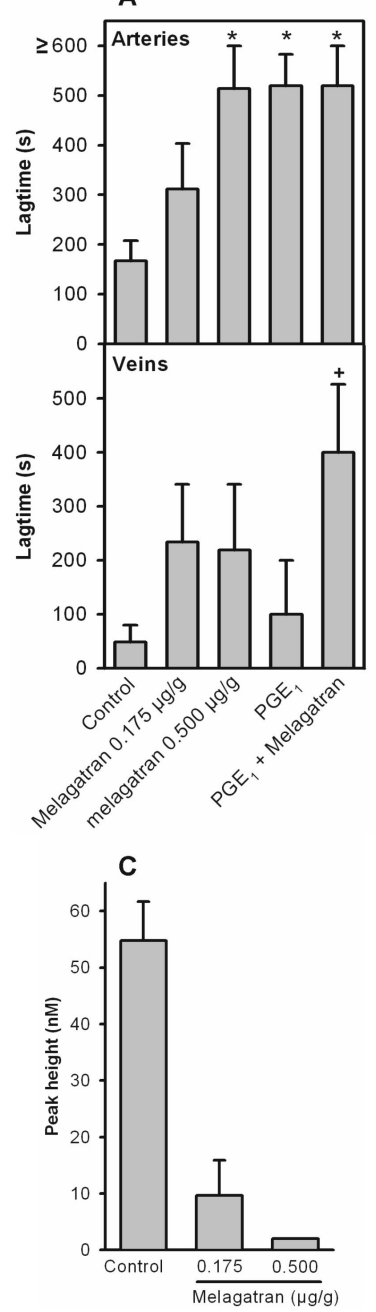

B
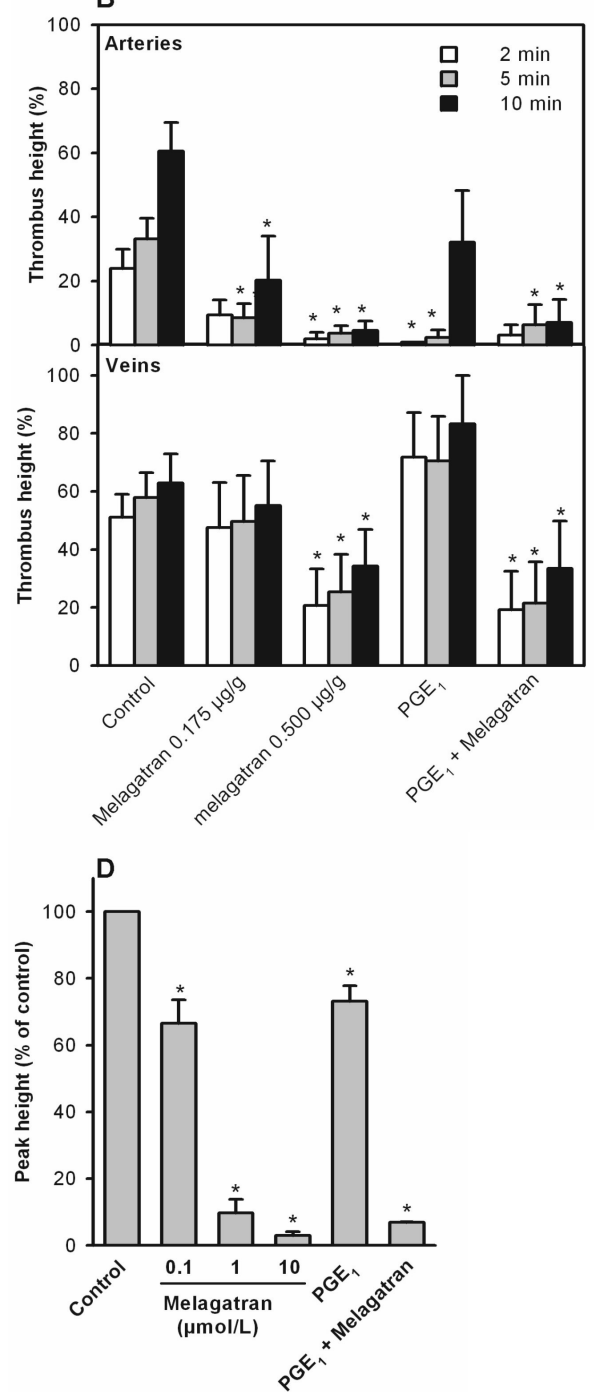

Figure 3 Complementary roles of thrombin and platelet activation in $\mathrm{FeCl}_{3}$-induced thrombus formation in arteries and veins. Mice were injected with saline vehicle (control), melagatran (0.175$0.500 \mu \mathrm{g} / \mathrm{g} \mathrm{bw}$ ) and/or prostaglandin $\mathrm{E}_{1}\left(\mathrm{PGE}_{1}, 0.4 \mathrm{mg} / \mathrm{g} \mathrm{bw}\right)$. Mesenteric vessels were damaged by topical application of $\mathrm{FeCl}_{3}$ as in Figure 1. (A) Lag-time to thrombus formation after $\mathrm{FeCl}_{3}$ application. (B) Thrombus height measured at indicated times after $\mathrm{FeCl}_{3}$ application (\% of vessel diameter). Data are means \pm SEM $(n=4-9) .{ }^{*} p<0.05 ;{ }^{+} p<0.07$ compared to control. (C) Effect of in vivo injection of melagatran $(0.175-0.5 \mu \mathrm{g} / \mathrm{g} \mathrm{bw})$ on thrombin generation. After in vivo experimentation, blood was collected, and PPP was prepared and supplemented with $4.0 \mu \mathrm{M}$ phospholipid vesicles. Thrombin generation was triggered with tissue factor/ $\mathrm{CaCl}_{2}$. (D) Effect of in vitro added inhibitors on thrombin generation. Mouse PRP $\left(1.5 \times 10^{8}\right.$ platelets $\left./ \mathrm{ml}\right)$ was pre-incubated with melagatran $(0.1-10 \mu \mathrm{M})$ and/or $\mathrm{PGE}_{1}(10 \mu \mathrm{M})$, and thrombin generation was triggered with tissue factor/CaCl . Data show effects on peak height relative to control condition; means \pm SEM $(n=3-5) ;{ }^{*} p<0.05$ compared to control. 
A

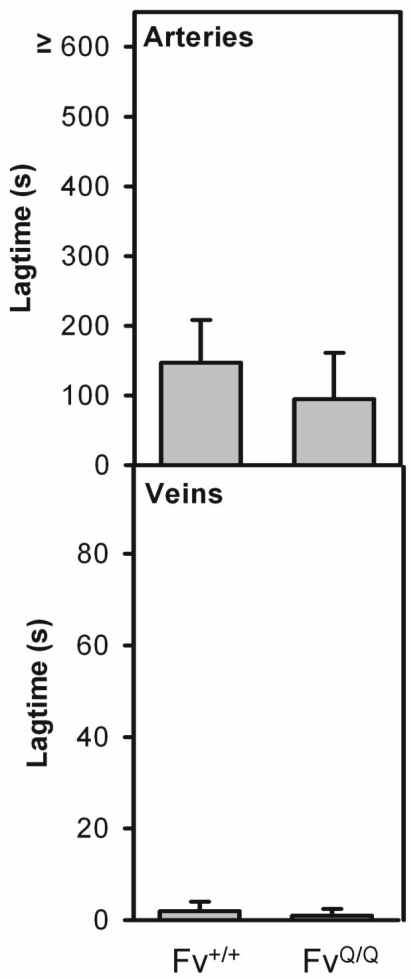

B

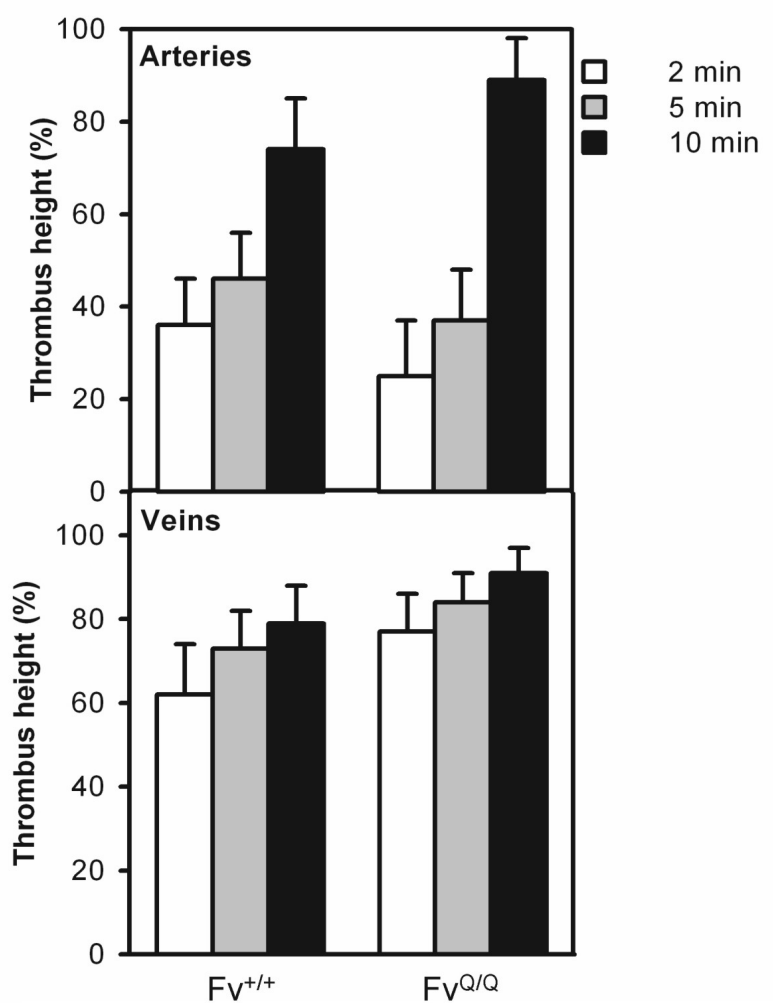

Figure 4 Normal $\mathrm{FeCl}_{3}$-induced thrombus formation in arteries and veins of factor $\mathrm{V}$ Leiden mice. Mesenteric vessels of homozygous factor $\mathrm{V}$ Leiden $\left(\mathrm{Fv}^{\mathrm{Q} / \mathrm{Q}}\right)$ and wildtype $\left(\mathrm{Fv}^{+/+}\right)$mice were subjected to $\mathrm{FeCl}_{3}$-induced thrombus formation. (A) Lag-time to thrombus formation after $\mathrm{FeCl}_{3}$ application. (B) Thrombus height at indicated times after $\mathrm{FeCl}_{3}$ application (\% of vessel diameter). Data are means \pm SEM $(n=8-13)$.

Similarly, when added to PRP in vitro, melagatran (Figure 3D) or heparin (not shown) dose-dependently reduced tissue factor-triggered thrombin generation; the $\mathrm{IC}_{50}$ for melagatran was about $0.5 \mu \mathrm{M}$. Together, these data stress the importance of thrombin generation and coagulation in this mouse thrombosis model, and, furthermore show that stronger inhibition of the thrombin-generating process is required to affect venous compared to arterial thrombus formation.

\section{Additive effect of platelet and thrombin inhibition on venous thrombus formation}

To inhibit platelet activation, the cAMP-elevating agent prostaglandin $E_{1}\left(P E_{1}\right)$ was used. In isolated mouse PRP, $10 \mu \mathrm{M} \mathrm{PGE}_{1}$ substantially reduced platelet aggregation (not shown) and platelet-dependent thrombin generation (Figure 3D, peak 
height reduced to $73 \pm 5 \%, p=0.003$ ). This corresponds to results obtained with human $\mathrm{PRP}^{6,27}$. In vivo treatment of mice with $0.4 \mathrm{mg} / \mathrm{g}$ bw $\mathrm{PGE}_{1}$ (giving a plasma concentration of about $10 \mu \mathrm{M}$ ) significantly delayed and reduced thrombus formation in arteries, but not in veins (Figure $3 \mathrm{~A}, \mathrm{~B}$ ). Ex vivo measurements demonstrated that the injected $\mathrm{PGE}_{1}$ caused a $40 \%$ reduction in thrombin formation.

Combined administration of $\mathrm{PGE}_{1}(0.4 \mathrm{mg} / \mathrm{g} \mathrm{bw})$ and the lower dose of melagatran $(0.175 \mu \mathrm{g} / \mathrm{g} \mathrm{bw})$ resulted in significant retardation and reduction of the thrombotic process, not only in arteries, but also in veins (Figure $3 \mathrm{~A}, \mathrm{~B}$ ). Thus, in veins, the combined administration was much more effective than that of $\mathrm{PGE}_{1}$ or moderate melagatran alone. Or stated otherwise, platelet inhibition by $\mathrm{PGE}_{1}$ or moderate thrombin inhibition by melagatran alone was sufficient to inhibit arterial thrombus formation, but the combined action was needed for reducing venous thrombosis.

\section{Unchanged thrombus formation in arteries and veins of factor $V$ Leiden mice}

To investigate the involvement of anticoagulant activity in the thrombus-forming process, we used transgenic mice carrying the factor $\mathrm{V}$ Leiden mutation (homozygous $\mathrm{FV}^{\mathrm{Q} / \mathrm{Q}}$ ), which renders factor $\mathrm{Va}$ relatively resistant to inactivation by activated protein $\mathrm{C}$ and hence enhances thrombin generation ${ }^{21,30}$. When compared to wildtype controls $\left(\mathrm{FV}^{+/+}\right.$), in $\mathrm{FV}^{\mathrm{Q} / \mathrm{Q}}$ mice neither the lag-time to thrombus formation (Figure $4 \mathrm{~A}$ ) nor the extent of thrombus formation (Figure 4B) was altered in arteries or veins. However, the time to arterial occlusion of $\mathrm{FV}^{\mathrm{Q} / \mathrm{Q}}$ mice was significantly shorter than that of $\mathrm{FV}^{+/+}$mice (462 \pm 62 vs. $531 \pm 41 \mathrm{~s}, \mathrm{n}=8, \mathrm{p}<0.05$ ). Apparently, in spite of the key role of thrombin in this process, resistance of factor $V a$ to inactivation by activated protein $C$, as in $F V^{Q / Q}$ mice, did not have a major effect on arterial and venous thrombus formation.

\section{Procoagulant platelets control thrombus formation in arteries and veins}

To investigate the role of procoagulant platelets in the thrombus-forming process, $\mathrm{FeCl}_{3}$ was applied to induce thrombus formation, and mice were subsequently injected with a tracer amount of FITC-labeled annexin A5 $(0.16 \mu \mathrm{g} / \mathrm{g} \mathrm{bw})$, which detects cell surface-exposed PS. Overlays of transmission and fluorescence images indicated that the thrombi in both arteries and veins incorporated labeled annexin A5 (Figure 5A), pointing to the presence of PS-exposing platelets. During the experiments no staining with FITC-annexin A5 was observed inside the vessel wall or in vessels without thrombi (not shown). 
A

\section{Baseline}
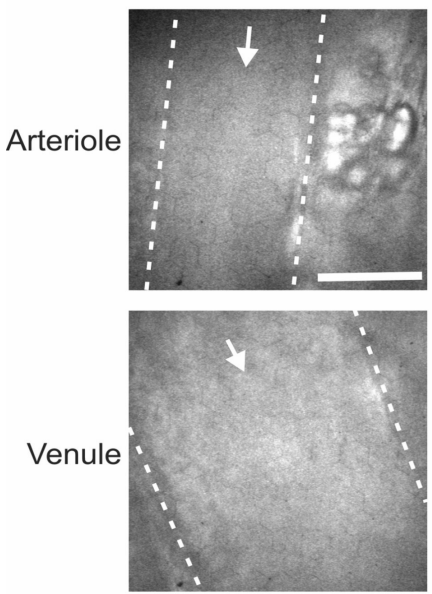

B

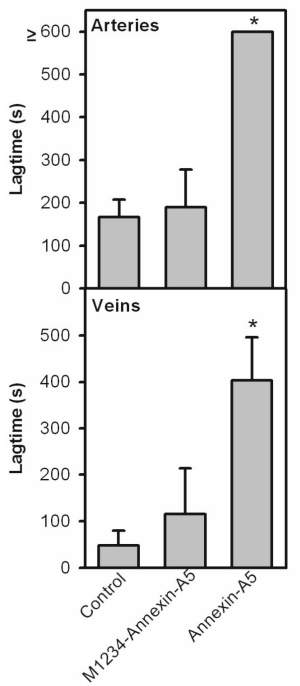

$5 \min$
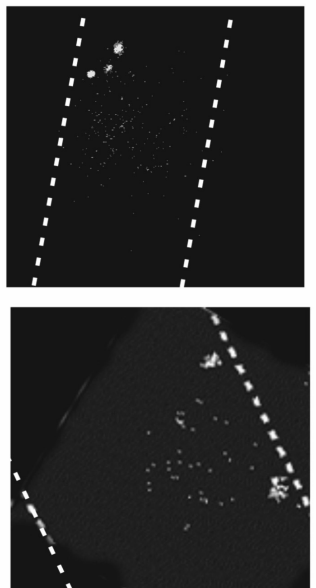

C
$10 \min$
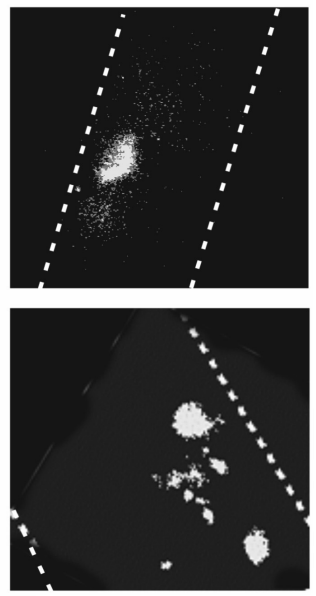

D

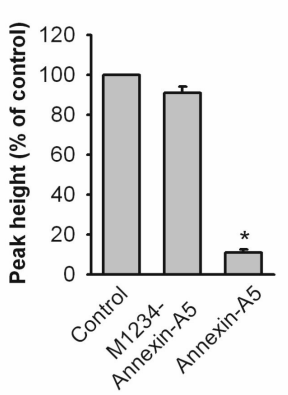

Figure $\mathbf{5}$ Role of platelet procoagulant activity in arterial and venous thrombus formation in vivo. (A) Vessel wall damage was induced by topical $\mathrm{FeCl}_{3}$ application, directly after which FITCannexin A5 $(0.16 \mu \mathrm{g} / \mathrm{g})$ was infused intravenously. Trans-illumination images were taken at baseline; fluorescence images were taken at 5 and 10 minutes after $\mathrm{FeCl}_{3}$ application. Dotted lines indicate vessel wall, arrows indicate direction of flow; bar represents $50 \mu \mathrm{m}$. (B) Mice were infused with a high dose of $7.7 \mu \mathrm{g} / \mathrm{g}$ bw annexin A5 or mutated M1234-annexin A5, resulting in plasma concentration of $70 \mu \mathrm{g} / \mathrm{ml}$. Mesenteric vessels were damaged by topical application of $\mathrm{FeCl}_{3}$. (B) Lag-time to thrombus formation after $\mathrm{FeCl}_{3}$ application. (C) Thrombus height measured at indicated time points after $\mathrm{FeCl}_{3}$ application (\% of vessel diameter). Data are means $\left.\pm \mathrm{SEM} \mathrm{(} n=6-7\right) ;{ }^{*} \mathrm{p}<0.05$ compared to control. Note that M1234-annexin A5 infusion led to a similar thrombus build-up in arteries and veins as vehicle (control) infusion $(p=0.179)$. (D) In vitro effect of annexin A5 on thrombin generation in PRP. Thrombin generation was measured in PRP, treated with a moderate dose $(10 \mu \mathrm{g} / \mathrm{ml})$ mutated M1234-annexin A5 or wildtype annexin A5. Values are thrombin peak heights as $\%$ of control (means \pm SEM, $n=3-4$ ). 
The importance of PS exposure was further investigated by injecting mice with a saturating dose $(7.7 \mu \mathrm{g} / \mathrm{g} \mathrm{bw})$ of unlabeled annexin A5. Quadruple-mutated annexin A5 (M1234-annexin A5, $7.7 \mu \mathrm{g} / \mathrm{g}$ bw) was used as a negative control. The M1234-annexin A5 has single amino acid mutations in each of the four $\mathrm{Ca}^{2+}$ binding sites that greatly reduces its affinity for binding to $\mathrm{PS}^{31}$. Whereas injection of M1234-annexin did not influence thrombus formation as compared to vehicle control ( $p \geq 0.18)$, wildtype annexin A5 almost completely inhibited this process in both arteries and veins (Figure 5B, C). In fact, in none of the 7 damaged arterioles more than little platelet deposition was detected within the 10-min time frame, while in 3 out of 6 venules only very small thrombi assembled.

Thrombin generation experiments in vitro showed that addition of $10 \mu \mathrm{g} / \mathrm{ml}$ annexin A5 to PRP was sufficient to reduce the thrombin peak to $11 \pm 1.6 \%(n=3)$ of control, while M1234-annexin A5 was without effect (Figure 5D). In plasma collected from mice injected with annexin A5 $(7.7 \mu \mathrm{g} / \mathrm{g} \mathrm{bw})$, thrombin generation was reduced to $17 \pm 4 \%(n=4)$ of control plasma. Thus, in either vessel type, thrombus formation appears to rely on PS exposure and ensuing thrombin generation by (activated) platelets. Similarly, in in vitro flow experiments (see Figure 1), addition of annexin A5 reduced PS exposure by platelets and clot formation (not shown).

\section{Discussion}

In this paper, we investigated the interaction mechanisms of platelets and coagulation in thrombus formation under in vivo conditions, using an established murine thrombosis model of vascular damage induced by $\mathrm{FeCl}_{3}$. In both arteries and veins, we detected substantial externalized PS on platelets trapped into thrombi, using fluorescently labeled annexin A5. This probe has previously also been used for in vivo monitoring of PS-exposing, apoptotic cardiomyocytes in a mouse model of ischemia/reperfusion of the heart ${ }^{32}$. A major finding was that injection of a high dose of annexin A5, sufficient to suppress PS-dependent thrombin generation in plasma, results in a profound delay in initiation and in an almost complete suppression of arterial and venous thrombus formation. In contrast, a mutated non-binding annexin A5, was without any effect. These in vivo data are in good agreement with results from in vitro flow experiments, where PS-exposing platelets were found to accumulate under conditions of high thrombin generation and clot formation. Together, this is first evidence for a key role of PS exposure and platelet-dependent coagulation in the thrombotic process in vivo, in both arteries and veins. This work thereby significantly extends knowledge from 
experiments in test tubes that PS-exposing platelets promote prothrombin cleavage ${ }^{9,13}$. Indirect evidence for the clinical importance of this process comes from the finding that Scott patients, whose platelets are deficient in PS exposure upon activation, are characterized by a mild bleeding defect ${ }^{33}$.

Strikingly, in this $\mathrm{FeCl}_{3}$-induced microvascular model the same initiating factors appear to be involved in the thrombus-forming process in arteries and veins. Accordingly, in both vessel types blocking of tissue factor with a monoclonal antibody or injection of inactivated factor VIla (both of which interventions block the tissue factor pathway of coagulation) delayed and suppressed thrombus formation. Others have shown that tissue factor, platelets and fibrin gradually accumulate into developing murine thrombi, produced in microvascular arterioles ${ }^{2}$. For the current model, we cannot answer the question whether ${ }^{34}$ or not ${ }^{35}$ blood-borne tissue factor is involved in the thrombotic process. However, the data do support the proposal that tissue factor is a promising target for new antithrombotic treatment ${ }^{36}$.

Another similarity between arteries and veins we found in this model, is that the absence of FcR $\gamma$-chain and GPVI delays and reduces thrombus formation in both vessel types. The arterial results agree with those of others, who found diminished arterial thrombus formation in mice lacking the FcR $\gamma$-chain, using a similar model ${ }^{3,37}$. This also holds for high shear flow studies showing impaired thrombus formation with blocked or absent GPVI signaling in vitro, regardless of the presence of coagulation ${ }^{23,25}$. In contrast, laser-induced thrombosis is not diminished in arteries of FcR $\gamma$-chain deficient mice, likely to due a high generation of thrombin after this type of injury ${ }^{3,4}$.

Furthermore, our results show that, in arteries as well as veins, thrombin is an important mediator of the thrombotic process. In both vessel types, thrombus formation is abrogated by infusion of the thrombin inhibitor melagatran at an established fully effective concentration. Interestingly, however, while in arteries also a lower, partly active melagatran concentration is inhibiting, in veins this concentration is without effect, except when given in combination with platelet-inhibiting $\mathrm{PGE}_{1}$. For arterial thrombus formation induced by $\mathrm{FeCl}_{3}$, laser or mechanical damage, significant contribution of thrombin is also noted by others ${ }^{1,4,5,18}$.

The importance of anticoagulation was investigated using $\mathrm{FV}^{\mathrm{Q} / \mathrm{Q}}$ mice carrying the factor $V$ Leiden mutation, rendering factor $V a$ relatively resistant to inactivation by activated protein $\mathrm{C}^{21}$. It has been proposed that factor $\mathrm{Va}$ inactivation is controlled by binding to the platelet surface ${ }^{12}$, implicating that thrombus formation is potentially regulated by factor $V a-p l a t e l e t$ binding. Here, we found that $F V^{Q / Q}$ vessels had no more than a small increase in arterial or venous thrombus formation; significant effects, i.e. on 
arterial occlusion, were only present at a late stage of thrombus formation. Thus, although in the present model arterial and venous thrombosis is controlled by coagulation factor activation (thrombin), factor $\mathrm{Va}$ inactivation only appears to play a significant role at later stages of the process. Therefore, our results do not support the observation that the factor $\mathrm{V}$ Leiden mutation enhances arterial thrombosis in mice ${ }^{38}$.

Taken together, the present data indicate that the thrombotic process in arteries as well as veins involves: (i) platelet-collagen interaction via GPVI/FcR $\gamma$-chain, (ii) tissue factor-induced initiation of thrombin generation, (iii) platelet activation and aggregation, and (iv) development of platelet procoagulant activity, i.e. PS exposure, to potentiate thrombin generation and clot formation. Apparently, in both arteries and veins the thrombotic process is driven by sequential loops of thrombin generation, platelet activation and PS exposure.

While the mechanisms of arterial and venous thrombus formation are strikingly similar, the present data also point to typical quantitative differences. Thrombus formation in veins was faster in onset than in arteries. Such differences between arteries and veins were also found in other, non- $\mathrm{FeCl}_{3}$ thrombosis models ${ }^{39}$. In the present model, one of the reasons of the faster onset of venous thrombosis may be a quicker penetration of $\mathrm{FeCl}_{3}$ through the relatively thin venous vessel wall. Another possible explanation is the slower dilution in veins of locally formed prothrombotic substances (factor VII, ADP, thrombin). Support for the latter comes from the observation that stronger inhibition of thrombin, or combined inhibition of thrombin and platelets, is required to suppress thrombus formation in veins in comparison to arteries. This points to a relatively high accumulation of thrombin in the slowly flowing venous blood. A third possibility is that more thrombin is formed in damaged veins, for instance because they may express more tissue factor, which is known to be distributed through the vascular system in a non-uniform way ${ }^{40}$.

In conclusion, the present study provides new insights into similarities and differences in the dynamic process of arterial and venous thrombus formation. In this murine model, platelet PS exposure appears to be an important regulatory process in either vessel type, integrating platelet activation and thrombin generation. This in vivo study thus indicates that platelet procoagulant activity may be a clinically relevant target for antithrombotic therapy. 


\section{Acknowledgments}

We thank M. Feijge for expert technical assistance. We acknowledge dr. M. Elg (Astra-Zeneca) for supply of melagatran, and dr. P. Tijburg (Novo Nordisk) for anti-tissue factor antibody and active site-inhibited factor VIla. This work was supported by grant 2002-B014 from the Netherlands Heart Foundation.

\section{References}

1. Sambrano GR, Weiss EJ, Zheng YW, Huang W, Coughlin SR. Role of thrombin signaling in platelets in haemostasis and thrombosis. Nature. 2001;413:74-78.

2. Falati S, Gross P, Merrill-Skoloff G, Furie BC, Furie B. Real-time in vivo imaging of platelets, tissue factor and fibrin during arterial thrombus formation in the mouse. Nat Med. 2002;8:1175-1181.

3. Dubois C, Panicot-Dubois L, Merrill-Skoloff G, Furie B, Furie BC. Glycoprotein VI-dependent and -independent pathways of thrombus formation in vivo. Blood. 2006;107:3902-3906.

4. Mangin P, Yap CL, Nonne C, Sturgeon SA, Goncalves I, Yuan Y, Schoenwaelder SM, Wright $\mathrm{CE}$, Lanza F, Jackson SP. Thrombin overcomes the thrombosis defect associated with platelet GPVI/FcR $\gamma$ deficiency. Blood. 2006;107:4346-4353.

5. van Gestel MA, Reitsma S, Slaaf DW, Heijnen VVT, Feijge MAH, Lindhout T, van Zandvoort MAMJ, Elg M, Reneman RS, Heemskerk JWM, oude Egbrink MGA. Both ADP and thrombin regulate arteriolar thrombus stabilization and embolization, but are not involved in initial hemostasis. Microcirculation. 2007;in press.

6. Reverter JC, Beguin S, Kessels H, Kumar R, Hemker HC, Coller BS. Inhibition of plateletmediated, tissue factor-induced thrombin generation by the mouse/human chimeric 7E3 antibody. Potential implications for the effect of c7E3 Fab treatment on acute thrombosis and "clinical restenosis". J Clin Invest. 1996;98:863-874.

7. Beguin S, Kumar R. Thrombin, fibrin and platelets: a resonance loop in which von Willebrand factor is a necessary link. Thromb Haemost. 1997;78:590-594.

8. Butenas S, Cawthern KM, van't Veer C, DiLorenzo ME, Lock JB, Mann KG. Antiplatelet agents in tissue factor-induced blood coagulation. Blood. 2001;97:2314-2322.

9. Heemskerk JWM, Bevers EM, Lindhout T. Platelet activation and blood coagulation. Thromb Haemost. 2002;88:186-193.

10. Swords NA, Mann KG. The assembly of the prothrombinase complex on adherent platelets. Arterioscler Thromb. 1993;13:1602-1612.

11. Baird TR, Walsh PN. The interaction of factor Xla with activated platelets but not endothelial cells promotes the activation of factor IX in the consolidation phase of blood coagulation. $\mathrm{J}$ Biol Chem. 2002;277:38462-38467.

12. Camire RM, Kalafatis M, Simioni P, Girolami A, Tracy PB. Platelet-derived factor Va/ Va Leiden cofactor activities are sustained on the surface of activated platelets despite the presence of activated protein C. Blood. 1998;91:2818-2829.

13. Zwaal RFA, Schroit AJ. Pathophysiological implications of membrane phospholipid asymmetry in blood cells. Blood. 1997;89:1121-1132.

14. Heemskerk JW, Vuist WM, Feijge MA, Reutelingsperger CP, Lindhout T. Collagen but not fibrinogen surfaces induce bleb formation, exposure of phosphatidylserine, and procoagulant activity of adherent platelets: evidence for regulation by protein tyrosine kinase-dependent $\mathrm{Ca}^{2+}$ responses. Blood. 1997;90:2615-2625. 
15. Siljander PRM, Munnix ICA, Smethurst PA, Deckmyn H, Lindhout T, Ouwehand WH, Farndale RW, Heemskerk JWM. Platelet receptor interplay regulates collagen-induced thrombus formation in flowing human blood. Blood. 2004;103:1333-1341.

16. Andersen H, Greenberg DL, Fujikawa K, Xu WF, Chung DW, Davie EW. Protease-activated receptor 1 is the primary mediator of thrombin-stimulated platelet procoagulant activity. Proceedings of the National Academy of Sciences of the United States of America. 1999;96:11189-11193.

17. Denis C, Methia N, Frenette PS, Rayburn H, Ullman Cullere M, Hynes RO, Wagner DD. A mouse model of severe von Willebrand disease: defects in hemostasis and thrombosis. Proc Natl Acad Sci U S A. 1998;95:9524-9529.

18. Ni H, Ramakrishnan V, Ruggeri ZM, Papalia JM, Phillips DR, Wagner DD. Increased thrombogenesis and embolus formation in mice lacking glycoprotein V. Blood. 2001;98:368-373.

19. André P, Delaney SM, LaRocca T, Vincent D, DeGuzman F, Jurek M, Koller B, Phillips DR, Conley PB. P2 $\mathrm{Y}_{12}$ regulates platelet adhesion/ activation, thrombus growth, and thrombus stability in injured arteries. J Clin Invest. 2003;112:398-406.

20. Takai T, Li M, Sylvestre D, Clynes R, Ravetch JV. FcR $\gamma$-chain deletion results in pleiotrophic effector cell defects. Cell. 1994;76:519-529.

21. Cui J, Eitzman DT, Westrick RJ, Christie PD, Xu ZJ, Yang AY, Purkayastha AA, Yang TL, Metz AL, Gallagher KP, Tyson JA, Rosenberg RD, Ginsburg D. Spontaneous thrombosis in mice carrying the factor $\vee$ Leiden mutation. Blood. 2000;96:4222-4226.

22. Sorensen BB, Rao LV. Interaction of activated factor VII and active site-inhibited activated factor VII with tissue factor. Blood Coagul Fibrinolysis. 1998;9 Suppl 1:S67-71.

23. Munnix ICA, Strehl A, Kuijpers MJE, Auger JM, van der Meijden PEJ, van Zandvoort MAM, oude Egbrink MGA, Nieswandt B, Heemskerk JWM. The glycoprotein VI-phospholipase C $\gamma 2$ signaling pathway controls thrombus formation induced by collagen and tissue factor in vitro and in vivo. Arterioscler Thromb Vasc Biol. 2005;25:2673-2678.

24. van Gestel MA, Heemskerk JW, Slaaf DW, Heijnen VV, Sage SO, Reneman RS, oude Egbrink MG. Real-time detection of activation patterns in individual platelets during thromboembolism in vivo: differences between thrombus growth and embolus formation. $\mathrm{J}$ Vasc Res. 2002;39:534-543.

25. Kuijpers MJ, Schulte V, Bergmeier W, Lindhout T, Brakebusch C, Offermanns S, Fassler R, Heemskerk JW, Nieswandt B. Complementary roles of glycoprotein VI and $\alpha 2 \beta 1$ integrin in collagen-induced thrombus formation in flowing whole blood ex vivo. Faseb J. 2003;17:685-687.

26. Hemker HC, Giesen P, Al Dieri R, Regnault V, de Smedt E, Wagenvoord R, Lecompte T, Beguin S. Calibrated automated thrombin generation measurement in clotting plasma. Pathophysiol Haemost Thromb. 2003;33:4-15.

27. Vanschoonbeek K, Feijge MA, Van Kampen RJ, Kenis H, Hemker HC, Giesen PL, Heemskerk JW. Initiating and potentiating role of platelets in tissue factor-induced thrombin generation in the presence of plasma: subject-dependent variation in thrombogram characteristics. J Thromb Haemost. 2004;2:476-484.

28. Gustafsson D, Elg M. The pharmacodynamics and pharmacokinetics of the oral direct thrombin inhibitor ximelagatran and its active metabolite melagatran: a mini-review. Thromb Res. 2003;109 Suppl 1:S9-15.

29. Poole A, Gibbins JM, Turner M, van Vugt MJ, van de Winkel JG, Saito T, Tybulewicz VL, Watson SP. The Fc receptor $\gamma$-chain and the tyrosine kinase Syk are essential for activation of mouse platelets by collagen. EMBO J. 1997;16:2333-2341.

30. Nicolaes GA, Dahlback B. Factor $V$ and thrombotic disease: description of a janus-faced protein. Arterioscler Thromb Vasc Biol. 2002;22:530-538.

31. Kenis H, Van Genderen H, Bennaghmouch A, Rinia HA, Frederik P, Narula J, Hofstra L, Reutelingsperger CP. Cell surface expressed phosphatidylserine and Annexin A5 open a novel portal of cell entry. J Biol Chem. 2004;279:52623-52629. 
32. Dumont EA, Reutelingsperger CPM, Smits JFM, Daemen MJAP, Doevendans PAF, Wellens HJJ, Hofstra L. Real-time imaging of apoptotic cell-membrane changes at the single-cell level in the beating murine heart. Nature Med. 2001;7:1352-1355.

33. Weiss HJ. Scott syndrome: a disorder of platelet coagulant activity. Semin Hematol. 1994;31:312-319.

34. Chou J, Mackman N, Merrill-Skoloff G, Pedersen B, Furie BC, Furie B. Hematopoietic cellderived microparticle tissue factor contributes to fibrin formation during thrombus propagation. Blood. 2004;104:3190-3197.

35. Day SM, Reeve JL, Pedersen B, Farris DM, Myers DD, Im M, Wakefield TW, Mackman N, Fay WP. Macrovascular thrombosis is driven by tissue factor derived primarily from the blood vessel wall. Blood. 2005;105:192-198.

36. Golino P, Cimmino G. Targeting tissue factor as an antithrombotic strategy. Semin Vasc Med. 2003;3:205-214.

37. Nieswandt B, Watson SP. Platelet collagen interaction: is GPVI the central receptor? Blood. 2003;102:449-461.

38. Eitzman DT, Westrick RJ, Shen Y, Bodary PF, Gu S, Manning SL, Dobies SL, Ginsburg D. Homozygosity for factor $V$ Leiden leads to enhanced thrombosis and atherosclerosis in mice. Circulation. 2005;111:1822-1825.

39. oude Egbrink MGA, van Gestel MA, Broeders MD, Tangelder GJ, Heemskerk JWM, Reneman RS, Slaaf DW. Regulation of microvascular thromboembolism in vivo. Microcirculation. 2005;12:287-300. 



\title{
Chapter 7
}

\section{Signaling-induced transient integrin} activation controls segregation of procoagulant and aggregatory microdomains in thrombus formation

\author{
Imke C. A. Munnix, Marijke J. E. Kuijpers, Jocelyn Auger, Christella M. L. G. D. \\ Thomassen, Peter Panizzi, Marc A. M. van Zandvoort, Jan Rosing, Paul E. Bock, Steve \\ P. Watson and Johan W. M. Heemskerk
}

Submitted for publication 


\begin{abstract}
Platelets play a dual role in thrombosis by forming aggregates and stimulating coagulation. We investigated the commitment of platelets to these separate functions during thrombus formation in vitro and in vivo. Flow of human or mouse blood over collagen under coagulant conditions in vitro results in fibrin-rich thrombi with platelets exposing phosphatidylserine (PS). Two-photon microscopy reveals these thrombi to be heterogeneous in composition. They partly consist of microdomains of aggregated, fibrin(ogen)-binding platelets with activated $\alpha$ llb $\beta 3$ integrins. These are segregated from strings of PS-exposing platelets, low in $\alpha \mathrm{llb} \beta 3$ activation but displaying increased binding of all components of the prothrombinase complex (factor $\mathrm{Va}$, factor $\mathrm{Xa}$ and prothrombin). Typically, "coated" platelets, binding factor Va, overlap both types of microdomains. In vivo, damage of the murine carotid artery leads to production of thrombi with a similar, patch-like composition. A key regulatory event in the appearance of PS-exposing platelets is the secondary down-regulation of active $\alpha \mathrm{llb} \beta 3$, which is mediated by increased tyrosine kinase activity. Together, these results point to a local segregation within thrombi of aggregated and coagulation-active platelets, whereby tyrosine kinases trigger to integrin inactivation, thus reducing the aggregatory properties of procoagulant platelets.
\end{abstract}

\title{
Introduction
}

Activated platelets have a dual role in hemostasis and thrombosis. They form the building blocks of a thrombus and provide the membrane surface for coagulation factor activation, which results in thrombin and fibrin formation ${ }^{1,2}$. Once formed, thrombin greatly enhances the activation and aggregation of platelets. Given this strong interdependency of thrombin generation and platelet activation, it is intuitively assumed that the platelets that participate in aggregate formation are also involved in coagulation.

The mechanism(s) by which platelets contribute to the coagulation process are still incompletely identified. Kinetic evidence shows that collagen/thrombin-activated platelets expose phosphatidylserine (PS) at their outer surface and then bind Gla domain-containing coagulation factors, mediating factor $\mathrm{Xa}$ and thrombin generation ${ }^{3}$. However, even after activation with strong $\mathrm{Ca}^{2+}$-mobilizing agonists, not all platelets expose $\mathrm{PS}^{4-6}$. Conversely, there is evidence that PS exposure alone is insufficient to fully explain the procoagulant effect of platelets ${ }^{7,8}$. Another point of debate is whether subfractions of activated platelets have specific functions in the coagulation process. Several reports indicate that only part of the PS-exposing platelets are capable to bind 136 
one or more of the coagulation factors $\mathrm{Va}$, VIIIa, IXa and $\mathrm{Xa}^{9-11}$. One study identifies a subpopulation of activated platelets with so-called SCIP morphology (for sustained calcium-induced platelet), which are targets for factor XIIla or other transglutaminases and partly express PS ${ }^{12}$. Some authors describe a subpopulation of collagen- and thrombin-activated (COAT or 'coated') platelets, which express serotonin binding sites at their outer surface that function in the assembly of sheets of fibrinogen, von Willebrand factor (VWF) and factor $\mathrm{Va}^{13-15}$. However, others conclude that factor XIIla is not required for generation of the coated platelet phenotype ${ }^{16}$. Thus, there is substantial evidence that individual platelets respond in a different way to collagen/thrombin activation by binding to coagulation factors. However, the mechanism of origin and the function of these differences are still unclear. Moreover, the relevance of this for the thrombus forming process is completely unknown.

Recently, we and others have shown that platelets which adhere to collagen under high shear flow conditions are heterogeneous with respect to $\mathrm{Ca}^{2+}$ signaling and PS exposure ${ }^{12,17}$. Here, we aimed to extend this work by hypothesizing that differences in intracellular signaling properties determine the 'fate' of a platelet to become either procoagulant or proaggregatory. Our results show that, both in flow chambers in vitro and in arterial thrombosis models in vivo, platelets in a thrombus appear to segregate into distinct microdomains with aggregatory or procoagulant functions. A key discriminatory event in the segregation process is the activation and subsequent inactivation of integrin $\alpha \mathrm{llb} \beta 3$.

\section{Materials and methods}

\section{Materials}

Convulxin was purified to homogeneity from the venom of Crotalus durissus terrificus (Latoxan, France) ${ }^{4}$. Annexin A5 labeled with Oregon Green (OG)-488, Alexa Fluor-568 (AF568) or AF647 was from Molecular Probes (Leiden, The Netherlands), as were OG488-conjugated human fibrinogen, Syto-44 and AF532-labeled streptavidin. Fluorescein isothiocyanate (FITC)-labeled monoclonal antibody against human Pselectin ( $\alpha$-CD62 mAb) was from WAK Chemie (Steinbach, Germany); FITC-labeled PAC1 antibody from BD Biosciences (San Jose, CA); (FITC-labeled) antiphosphotyrosine mAb 4G10 from Upstate Biotechnology (Dundee, UK); anti-actin mAb AC-40 from Sigma (St. Louis, MO). Lotrafiban was a gift from GlaxoSmithKline (Middlesex, UK). Biotin-pentylamine-succinylated bovine serum albumin (BPA-sBSA), 
prepared by reacting succinylated BSA with biotin-pentylamine, was kindly provided by dr. G. Dale (Dept. of Medicine, Health Science Center, Oklahoma). BPA-sBSA recognizes serotonin binding sites on coated platelets and is less sensitive to oxidation than the parent compound, biotin-BSA- $(5 \mathrm{HT})_{n}{ }^{14}$. Biotin was detected with AF488- or AF532-labeled streptavidin. Other materials were from sources described earlier ${ }^{17}$.

\section{Fluorescent coagulation factors}

Active site OG-labeled, human factor Xa was prepared by inactivation of native factor Xa with $N^{\alpha}$-[(acetylthio)acetyl]-(D-Phe)-Pro-Arg- $\mathrm{CH}_{2} \mathrm{Cl}$, and covalent modification with OG488-iodoacetamide following mild $\mathrm{NH}_{2} \mathrm{OH}$ treatment, as described ${ }^{18}$. OGprothrombin was labeled at the active site by a similar method, following formation of the catalytic site on the prothrombin zymogen by the use of a staphylocoagulase fragment ${ }^{19}$. Stoichiometries of $O G$ incorporation into factor $\mathrm{Xa}$ and prothrombin were 0.8 and $0.9 \mathrm{~mol}$ probe per mol protein, respectively. OG-prothrombin had $0.1 \%$ residual native prothrombin, determined as described ${ }^{19}$. Bovine factor $V$, purified as described ${ }^{20}$, was suspended in phosphate-buffered saline and labeled with AF488 protein labeling kit using a PD-10 column (Molecular Probes). The AF-488 labeled factor $\mathrm{V}$ contained 15 mol probe per mol protein. After activation with thrombin, the labeled factor $V a$ had retained its cofactor function in enhancing factor Xa activity. SDS-gelelectrophoretic analysis under reducing conditions showed that both the heavy and light chains of factor $\mathrm{Va}$ were labeled. Concentrations of labeled coagulation factors were confirmed by protein assay.

\section{Collection of human and mouse blood}

Blood was obtained from healthy volunteers with full informed consent. For experiments in the absence of coagulation, blood was collected into $40 \mu \mathrm{M} D$-Phe-ProArg-chloromethyl ketone (PPACK) in 10\% saline, and supplemented hourly with additional $20 \mu \mathrm{M}$ PPACK. For experiments involving coagulation, blood was collected in $10 \% 0.129 \mathrm{M}$ trisodium citrate.

Wildtype 12-week-old C57BI/6 mice of either sex (20-25 g) were obtained from Charles River (Maastricht, The Netherlands). Blood was collected under anesthesia with ketamine and xylazine (Eurovet, Bladel, The Netherlands) by orbital puncture. For experiments in the absence of coagulation, blood was collected in PPACK/heparin ${ }^{21}$; for experiments involving coagulation, blood was collected into $0.129 \mathrm{M}$ trisodium citrate. Experiments were approved by the local animal care and use committees. 


\section{Two-photon laser scanning microscopy (TPLSM) and confocal microscopy}

TPLSM was performed with a BioRad 2100 multiphoton system. Excitation was with a Spectra Physics Tsunami Ti:Sapphire laser, tuned and mode-locked at $800 \mathrm{~nm}$, producing pulses of $100 \mathrm{fs}$ wide (repetition rate $82 \mathrm{MHz}$ ), which was connected to an upright Nikon E600FN fluorescence microscope ${ }^{22}$. Two photomultipliers with separate pinholes detected fluorescence, selected by optical filters, at 508-523 nm and 570-620 $\mathrm{nm}$. A third photomultiplier detected fluorescence above $660 \mathrm{~nm}$ from a parallel-placed red diode laser, exciting at $647 \mathrm{~nm}$. This system was used for confocal scanning of thrombi in flow chambers during or after perfusion, and for deep scanning of intact carotid arteries, mounted in a home-build perfusion chamber. Thrombi were double or triple labeled to detect fluorescence from the probes OG488 (color-coded green), AF568 or Syto-44 (color-coded blue), and AF647 (color-coded red). Optical sections were scanned in Kalman filtering mode without further image processing. Single-photon, twocolor confocal laser scanning microscopy, using a Leica confocal microscope (DM, IRE2; Leica, Milton Keynes, UK), was performed as described ${ }^{23}$. Analysis of all confocal images (gray level bit maps) and 3D reconstruction of images were with ImagePro/LaserPix software (Media Cybernetics, Silver Spring, MD). Degree of colocalization of two fluorophores was evaluated using the Pearson's correlation coefficient $\left(R_{r}\right)$, which describes the overlap between two colored patterns, and is independent upon pixel intensity values. The overlap coefficient $(R)$ and the sub-coefficients $k_{1}$ and $k_{2}$, which vary with differences in color intensities, were also calculated.

\section{Thrombus formation on collagen under flow}

Human or murine blood was perfused at shear rate of $150-1000 \mathrm{~s}^{-1}$ over a collagen surface, as described ${ }^{24}$. Briefly, glass coverslips were coated with fibrillar Horm type-I collagen, blocked with Hepes buffer pH 7.45 (5 mM Hepes, 136 mM NaCl, 2.7 mM $\mathrm{KCl}, 0.42 \mathrm{mM} \mathrm{NaH}_{2} \mathrm{PO}_{4}$ and $1 \% \mathrm{BSA}$ ), and then placed in a parallel plate flow chamber (slit depth of $50 \mu \mathrm{m}$ ). Blood pre-incubated for 15 minutes with inhibitors and/or probes, was perfused for up to 4 minutes over the collagen. Thereafter, the flow chamber was post-perfused for a further 4 minutes with Hepes buffer, $\mathrm{pH} 7.45$ containing $2 \mathrm{mM} \mathrm{CaCl}$ and $1 \mathrm{U} / \mathrm{mL}$ heparin. For coagulation experiments, citrate-anticoagulated blood was coperfused with 10 vol\% of Hepes buffer, pH 7.45 containing 20 pM tissue factor and 200 $\mathrm{mM} \mathrm{CaCl} 2$ upon entry into the flow chamber ${ }^{24}$.

Bright-field phase-contrast and fluorescence images of adherent platelets were also recorded using a non-confocal two camera system ${ }^{25}$. Surface coverage with 
platelets was analyzed using ImagePro software. Data from $>10$ different fields of view were averaged per experiment without image processing.

\section{Thrombus formation in vivo}

Twelve-week-old mice were anesthetized by subcutaneous injection of ketamine and xylazine, followed by continuous infusion of ketamine. Fluorescently labeled compounds were administered intravenously through a PE-10 catheter in the tail vein $^{26}$. Carotid arteries were dissected free and ligated vigorously for 5 minutes to induce vascular injury. In other animals, the adventitial surface of the carotid artery was damaged by local application of a filter paper $(0.5 \times 1.0 \mathrm{~mm})$ with $1 \mathrm{M} \mathrm{FeCl}_{3}$ for 5 minutes. With either method, thrombus formation was allowed to proceed for 10 minutes, after which fluorescence in the still intact vessel was monitored by TPLSM. For ex vivo evaluation, $5 \mathrm{~mm}$ of the artery was carefully removed, mounted between two micropipettes in a perfusion chamber, and subjected to 1.0 atmosphere pressure ${ }^{22}$. Mounted arteries were post-labeled for 30 minutes with Syto-44 $(2 \mu \mathrm{M}$ in phosphatebuffered saline), to stain for nuclei.

\section{Flow cytometry}

Diluted PRP or washed platelets $\left(1 \times 10^{8}\right.$ platelets $\left./ \mathrm{mL}\right)$ were activated with 50 $\mathrm{ng} / \mathrm{mL}$ convulxin and $4 \mathrm{nM}$ thrombin in the presence of $2 \mathrm{mM} \mathrm{CaCl}_{2}$ for $5-30$ minutes. Samples were incubated with fluorescent labels and/or antibodies, as described in the text. For double labeling experiments, probes exciting at 488 and $647 \mathrm{~nm}$ were added simultaneously at saturating concentrations. Detection of fluorescence was with a FACScan flow cytometer, equipped with an argon and a red diode laser (BectonDickinson, Franklin Lakes, NJ). For analysis, platelets were gated based on their forward scatter/side scatter (FSC/SSC) characteristics. A minimum of 10,000 events was counted per assay. Control measurements were performed with unlabeled/stimulated and labeled/unstimulated platelets. List-mode data were analyzed using WinMDI 2.8 software (http://facs.scripps.edu).

\section{Protein tyrosine phosphorylation in adherent platelets}

After flow experiments, adherent platelets on collagen-coated coverslips were stained with AF647-annexin A5, and then fixed for staining with FITC-4G10 antiphosphotyrosine $\mathrm{mAb}$. Alternatively, platelets on coverslips were carefully lysed with icecold NP-40-based lysis buffer pH 7.4 (300 mM NaCl, 20 mM Tris-HCl, 2 mM EGTA, 2 
$\mathrm{mM}$ EDTA, $2 \mathrm{mM} \mathrm{Na}_{3} \mathrm{VO}_{4}, 1 \mathrm{mM}$ 4-(2-aminoethyl)-bezenesulfonylfluoride, $10 \mu \mathrm{g} / \mathrm{ml}$ leupeptin, $10 \mu \mathrm{g} / \mathrm{ml}$ aprotinin, $1 \mu \mathrm{g} / \mathrm{ml}$ pepstatin, $2 \% \mathrm{NP}-40)$. Protein was quantified in the lysates with a BioRad DC protein kit. Lysates with calculated equal protein amounts were resolved on $10 \%$ SDS-PAGE gels, then transferred to blotting membranes by semi-dry transfer. Membranes were immuno-blotted using an ECL system (Amersham Biosciences, Bucks, UK) with 4G10 mAb followed by stripping of the membranes and reprobing with AC-40 anti-actin mAb to verify equivalent loading ${ }^{27}$.

\section{Statistics}

Differences were tested on significance with the Mann-Whitney $U$ test using the statistical package for social sciences (SPSS 11.0, Chicago, IL). Results are given as mean values $\pm S D$, unless otherwise indicated.

\section{Results}

\section{Microdomains of aggregated and procoagulant platelets in thrombi formed under flow}

In the absence of coagulation, flow of human or murine blood over collagen leads to GPVI-dependent formation of thrombi containing PS-exposing platelets ${ }^{21,25,26}$. We studied how the tissue factor coagulation pathway contributed to this thrombus formation, by flowing human blood over collagen under high shear conditions in the presence of different fluorescent labels. Using PPACK-treated blood, OG-labeled fibrinogen $(0.2 \mathrm{mg} / \mathrm{mL})$ slowly, but steadily incorporated into platelet aggregates that were formed on collagen (Figure $1 \mathrm{~A})$. The probe OG-annexin A5 $(0.5 \mu \mathrm{g} / \mathrm{mL})$, which labels exposed $\mathrm{PS}^{4}$, only started to accumulate after a delay of 200 seconds (Figure 1B). When coagulation was triggered by co-perfusion of citrate blood together with tissue factor $/ \mathrm{CaCl}_{2}$, the formation of platelet aggregates and fibrin fibers was followed by that of larger clots containing erythrocytes. The incorporation of OG-fibrinogen was increased in this condition, and it further enhanced at the time point ( 170 seconds) of clot formation (Figure $1 \mathrm{~A})$. The addition of OG-annexin $\mathrm{A5}$, which is an anticoagulant ${ }^{28}$, typically delayed the clotting time to 200 seconds. After this time point, annexin A5 labeling greatly increased (Figure 1B, see also below). 

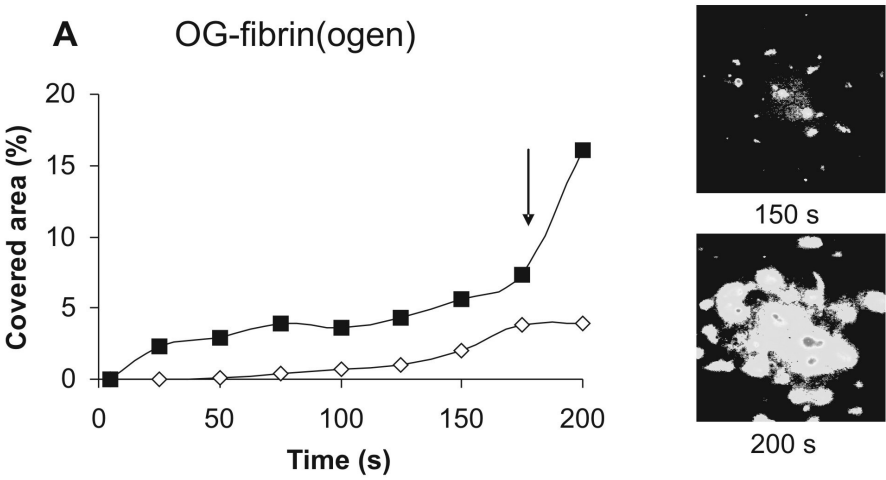

$150 \mathrm{~s}$

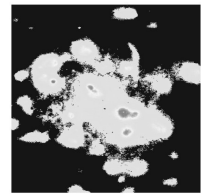

$200 \mathrm{~s}$

B OG-annexin A5

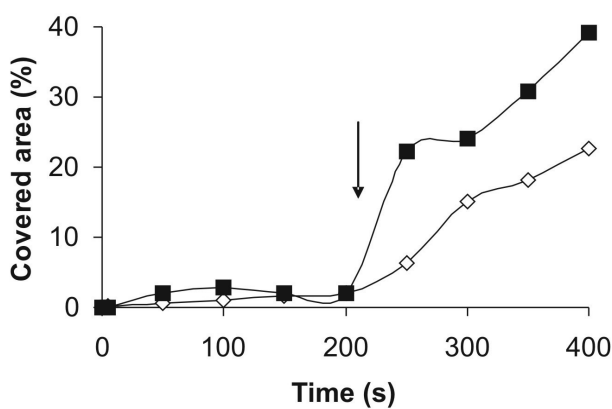

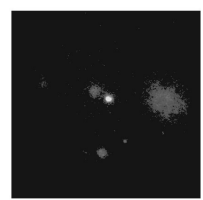

$200 \mathrm{~s}$

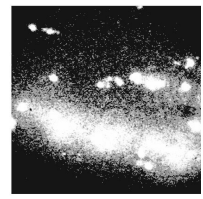

$250 \mathrm{~s}$

Figure 1 Time-dependent accumulation of labeled fibrin(ogen) and annexin A5 in thrombi formed in the absence or presence of coagulation. Human blood containing $0.2 \mathrm{mg} / \mathrm{mL} \mathrm{OG-}$ fibrinogen (A) or $0.5 \mu \mathrm{g} / \mathrm{mL}$ OG-annexin A5 (B) was perfused over collagen at a shear rate of 1000 $\mathrm{s}^{-1}$, and fluorescent images were captured from the collagen surface. PPACK-anticoagulated blood was used (open diamonds) or, alternatively, citrate-anticoagulated blood that was co-perfused with $2 \mathrm{pM}$ tissue factor and $2 \mathrm{mM}$ free $\mathrm{CaCl}_{2}$ (final concentrations) to reach physiological $\mathrm{Ca}^{2+} / \mathrm{Mg}^{2+}$ concentrations (filled squares). Surface area coverage with fluorescence of a representative experiment out of 4 performed is shown; arrows indicate appearance of microscopic clots. Images $(150 \times 150 \mu \mathrm{m})$ shown are examples of experiments in which coagulation occurred (150-250 s).

Multicolor TPLSM with high optical resolution and high penetration power was used to better localize the bound OG-fibrin(ogen) and AF647-annexin A5 within human and murine thrombi formed on collagen. These labels were simultaneously or sequentially added to the blood, either during or after flow, with essentially the same results (data not shown). Comparison of bright-field contrast images and two-color fluorescent images indicated that OG-fibrinogen was only present on aggregated platelets, whilst AF647-annexin A5 bound a distinct population of single platelets (Figure 2, upper and middle rows). Triggering of coagulation with tissue factor $/ \mathrm{CaCl}_{2}$ did not influence the labeling of OG-fibrin(ogen), still binding to aggregated platelets. Again, AF647-annexin A5 labeled a different population of platelets around the clots. The same 
staining patterns were obtained with both human and murine blood (Figure 2), including when any one of the two labels was omitted (data not shown). Thus, the heterogeneous labeling pattern was not due to competition between labels for the same binding sites on platelets.

'Coated' platelets are recognized by their property to bind multi-amine, serotonin-like compounds such as BPA-sBSA, and may participate in coagulation ${ }^{13,14}$. To detect the formation of coated platelets under flow, we allowed thrombi to form on collagen in the presence of labeled BPA-sBSA. Simultaneously, AF647-annexin A5 was present in this experiment to detect PS-exposing platelets. Surprisingly, the BPA-sBSA labeling pattern was markedly different from that of annexin A5 in both human and

A
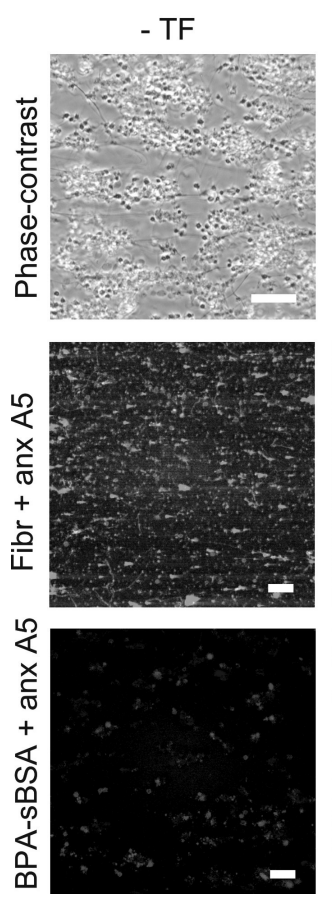

Human
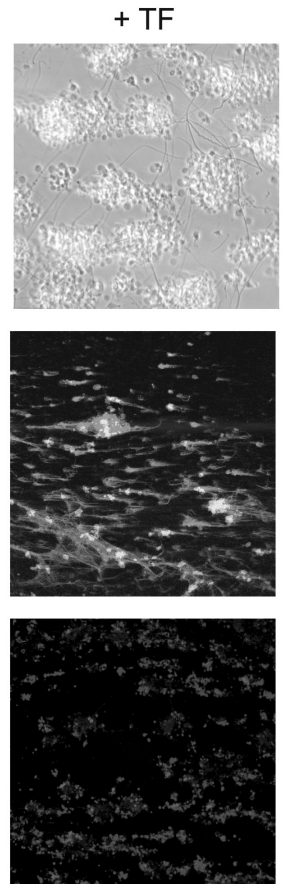

B
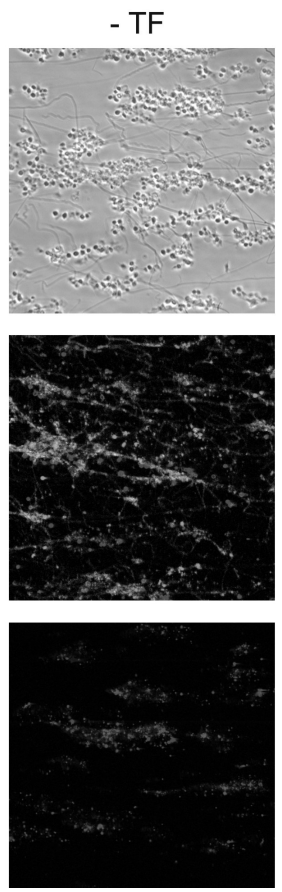

Mouse
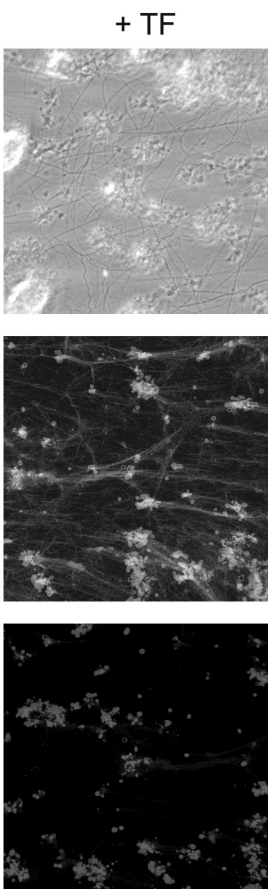

Figure 2 Heterogeneity in human and murine thrombi formed on collagen. Flow experiments were performed with human (A) or murine (B) blood in the absence of tissue factor (-TF) using PPACK-anticoagulated blood (left columns); or with citrate blood that was perfused together with tissue factor (+TF, $2 \mathrm{pM}$, f.c.) and $\mathrm{CaCl}_{2}\left(2 \mathrm{mM}\right.$ free $\mathrm{Ca}^{2+}$, f.c.) to allow coagulation (right columns). Standard perfusion time was 4 minutes at a shear rate of $1000 \mathrm{~s}^{-1}$. Blood was preincubated with 0.2 $\mathrm{mg} / \mathrm{mL}$ OG-fibrinogen. Alternatively, preincubation was with $50 \mu \mathrm{g} / \mathrm{mL}$ BPA-sBSA and post-labeling with $1 \mu \mathrm{g} / \mathrm{mL}$ AF532-labeled streptavidin. In both cases, AF647-annexin A5 was also present. Upper panels: bright-field phase-contrast images after perfusion. Middle panels: TPLSM images of OG-fibrinogen and AF647-annexin A5 fluorescence. Lower panels: TPLSM images of BPA-sBSA and AF647-annexin A5 staining. Images are representative of 4-8 experiments; bars indicate 20 $\mu \mathrm{m}$. 
mouse blood, with many of the fluorescent BPS-sBSA corresponding to platelets in aggregates (Figure 2, lower row). Clot (thrombin) formation affected the labeling pattern only slightly, although some of the label coincided with annexin A5. Control experiments indicated that BPS-sBSA labeling was not affected by the presence of annexin A5 (not shown). This pointed to a clear difference between coated and PS-exposing platelets.

The biphasic increase in annexin A5 labeling under coagulant conditions suggested that platelets expose PS after interaction with either collagen or clot material (e.g. fibrin). This was indeed visible in high magnification images (Figure 3 ). In the absence of clots, or prior to their formation, only isolated, collagen-bound platelets with a bleb-shaped appearance bound annexin A5. A few minutes after coagulation, strings or patches of annexin A5-positive, bleb-shaped platelets appeared around the clots. Interestingly, the majority of aggregated platelets did not form blebs nor stained positively for annexin A5. Thus, microdomains of PS-exposing platelets are clearly separated from the microdomains of aggregated platelets.

\section{Heterogeneity of integrin activation and PS exposure upon stimulation of collagen and thrombin receptors}

To search for the mechanism responsible for the heterogeneity, other dual labeling flow studies were performed under coagulant conditions in the presence of FITC-PAC1 mAb (detecting activated $\alpha \mathrm{llb} \beta 3$ ) and AF647-annexin A5 (for PS exposure).
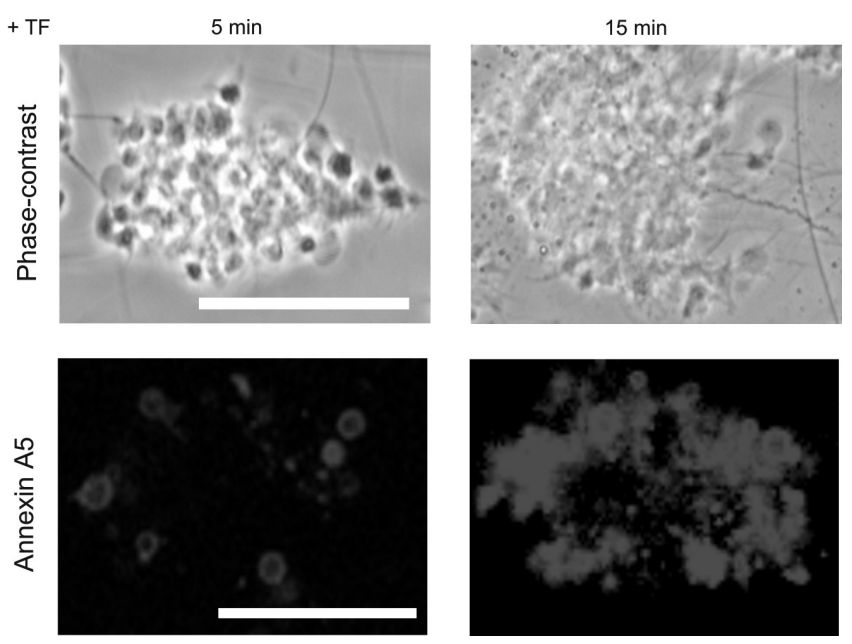

Figure 3 Bleb-shaped annexin A5-binding platelets on fibrin-containing aggregates. Human thrombi were formed on collagen during perfusion with tissue factor, and stained as described for Figure 2. Representative high-resolution phase-contrast and fluorescence images are shown after 5 (left) and 15 minutes (right) of perfusion. Bars indicate $20 \mu \mathrm{m}$. 
TPLSM showed that platelets assembled into aggregates and clots expressed activated $\alpha$ llb $\beta 3$ (Figure 4A). These platelets were well separated from the annexin A5-binding platelets (which did not bind PAC1), e.g. around clots. Again the same labeling patterns were obtained, when the experiments were performed with either probe alone (not shown). Control experiments indicated that the aggregated and bleb-shaped platelets both bound $\mathrm{mAb}$, directed against activation-independent epitopes of $\alpha \mathrm{llb} \beta 3$, indicating that integrins were still present on the PS-exposing platelets.

To validate these findings, also platelets in suspension were stimulated with a GPVI agonist, convulxin, alone or in combination with thrombin. Two-color flow cytometry showed that populations of FITC-PAC1 positive and negative platelets were well separated in the FL1 channel, while those of AF647-annexin A5 positive and negative cells were separated in the FL4 channel (Figure 4B). Time curves indicated that shortly after stimulation, most of the platelets bound FITC-PAC1, but were negative for AF647annexin A5 (Figure 4B,C). After 10-15 minutes, PAC1 binding was down-regulated in the

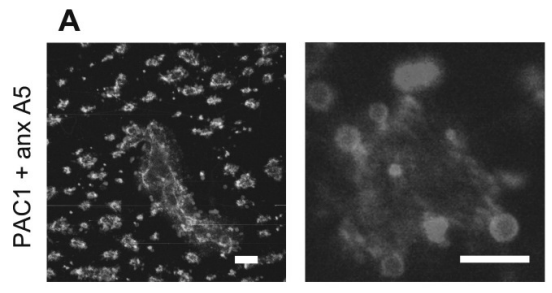

C convulxin

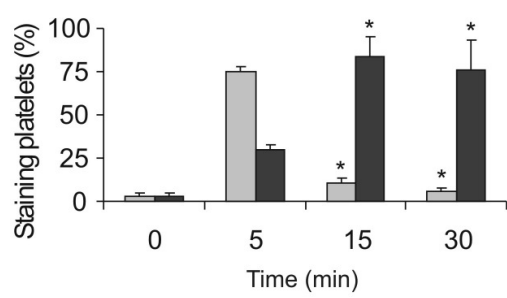

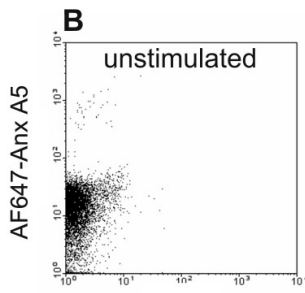

FITC-PAC1

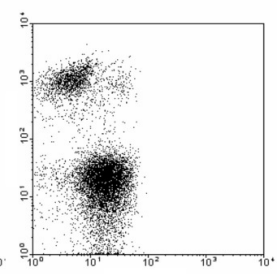

FITC-PAC1

convulxin + thrombin

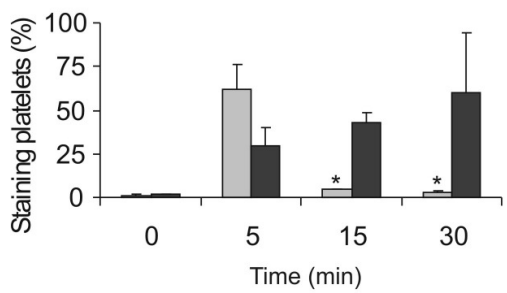

Figure 4 Temporary integrin activation state in procoagulant platelets. (A) Human thrombi were formed on collagen during tissue factor-induced coagulation, as described for Figure 2. Stains were $0.6 \mu \mathrm{g} / \mathrm{mL}$ FITC-PAC1 and $0.5 \mu \mathrm{g} / \mathrm{mL}$ AF647-annexin A5. Representative two-photon images are shown of FITC and AF647 fluorescence at lower and higher magnifications. Bars indicate $20 \mu \mathrm{m}$. (B, C) Washed platelets were stimulated in the presence of $2 \mathrm{mM} \mathrm{CaCl}_{2}$ with $50 \mathrm{ng} / \mathrm{mL}$ convulxin alone or with $4 \mathrm{nM}$ thrombin, for 5-30 minutes. (B) Representative dot plots are given of FL1 (FITC) versus FL4 (AF647) after 5 minutes of stimulation with convulxin. (C) Two-color flow cytometry after co-staining at indicated times with FITC-PAC1 and AF647-annexin A5, showing transient appearance of PAC1 binding sites and persistent PS exposure. Data are percentages of platelets staining with FITC-PAC1 (grey bars) or OG-annexin A5 (black bars). Mean $\pm S D(n=4)$, ${ }^{*} p<0.05$ compared to $t=5$ minutes. 
majority of the platelets, which now bound annexin A5. Pretreatment of platelets with the transglutaminase inhibitor, mono-dansyl cadaverine (MDC), or the calpain inhibitor, calpeptin, left annexin A5 binding unchanged, but caused a $30 \%$ or $3 \%$ decrease in PAC1 binding, respectively. Apparently, transglutaminase and calpain are not major factors in regulating the inactivation of integrins and the heterogeneity in PS exposure.

\section{Further characterization of microdomains of PS-exposing platelets in thrombi}

It was shown earlier that PS-exposing membranes function as assembly sites for the prothrombinase complex, to form thrombin ${ }^{29}$. To investigate this further, flow studies were performed with blood containing labeled factors of this complex, i.e. AF488factor Va, OG-factor Xa or OG-prothrombin, always in the simultaneous presence of AF647-annexin A5. Without coagulation, weak staining was visible at the aggregated platelets (not shown). In the presence of tissue factor and coagulation, the labeling of thrombi with these factors increased, e.g. AF488-factor Va fluorescence per pixel increased by 2.3 fold $(n=4)$. High-magnification images showed that particularly patches of (bleb-formed) platelets were double-stained with annexin A5 and the coagulation factors (Figure 5A). The PS-exposing platelets also stained positively for CD62. Further evidence that especially the PS-exposing platelets may have a function in coagulation

A
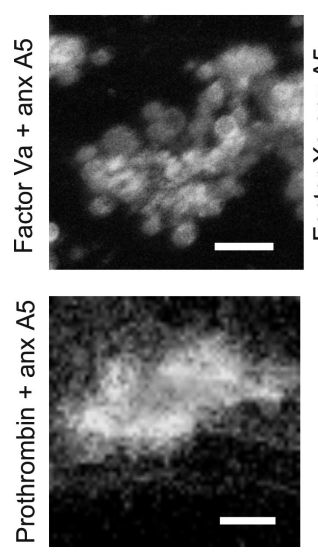
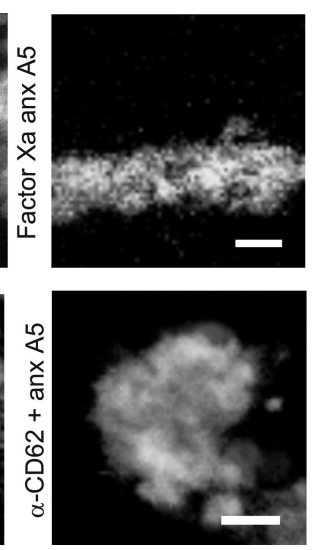

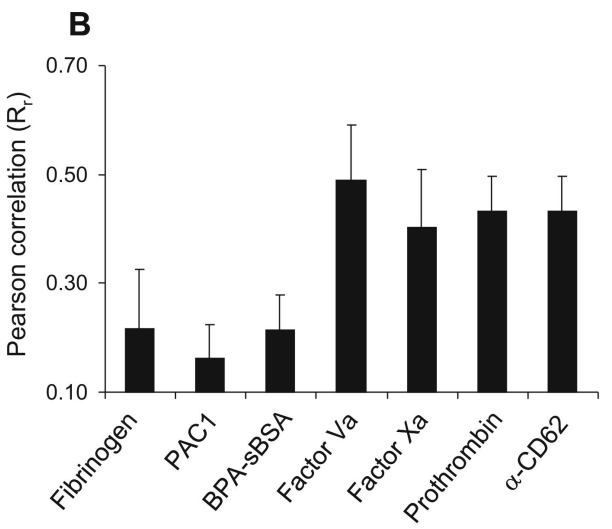

Figure 5 Partial overlap of coagulation factor and annexin A5 binding to stimulated platelets. Human thrombi were generated on collagen under coagulant conditions in the presence of AF647annexin A5 (see Figure 2) in combination with either 20 nM AF488-factor Va, 200 nM OG-prothrombin, $100 \mathrm{nM}$ OG-factor Xa or $1.25 \mu \mathrm{g} / \mathrm{mL}$ FITC- $\alpha$-CD62 mAb. (A) Representative TPLSM fluorescence images are shown of AF647-annexin A5 and indicated coagulation factor or antibody. Bars indicate 20 $\mu \mathrm{m}$. (B) Pattern overlap analysis of TPLSM images with annexin A5 and indicated factor or antibody. Pearson's correlation coefficients $\left(R_{r}\right)$ of corresponding green and red bit maps are given. Data are from at least 4 experiments. 
came from quantitative overlap analysis of the various sets of two-colored fluorescence images. The Pearson's correlation coefficient $\left(R_{r}\right)$ was calculated to determine the pattern overlap of complementary images of red annexin A5 and green probe. Strikingly, this coefficient was low for green fibrinogen, PAC1 or BPA-sBSA, but much higher for green factor $\mathrm{Va}$, factor $\mathrm{Xa}$, prothrombin or anti-CD62 mAb (Figure 5B). Quite similar results were obtained when the overlap coefficient $(R)$ was calculated for the same image sets (not shown), although it is sensitive for color intensity variation.

Two-color flow cytometric analysis was performed, following platelet stimulation with convulxin and thrombin, to confirm the separation of platelets into groups with different properties. On average, the population of stimulated, annexin A5-negative platelets relatively weakly bound the fluorescent-labeled factor $\mathrm{Va}$, factor $\mathrm{Xa}$ and

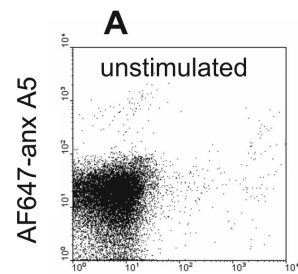

AF488-Factor Va

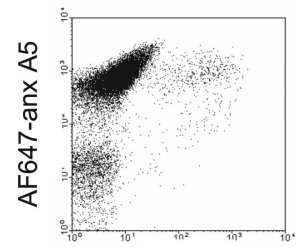

OG-Factor Xa

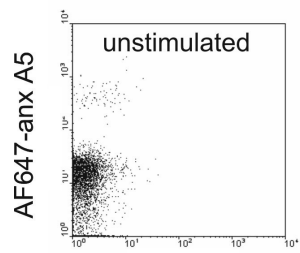

FITC- $\alpha-C D 62$

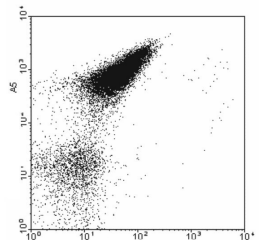

AF488-Factor Va

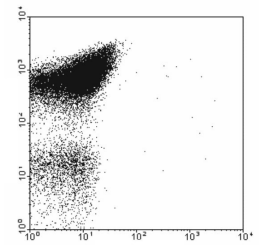

OG-Prothrombin

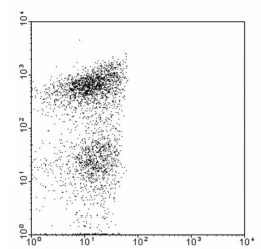

FITC- $\alpha-C D 62$

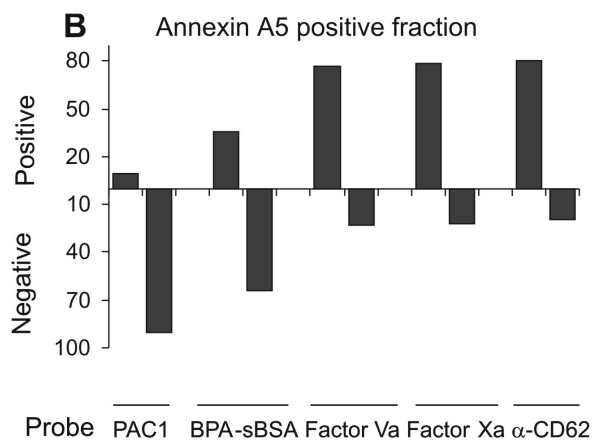

Annexin A5 negative fraction

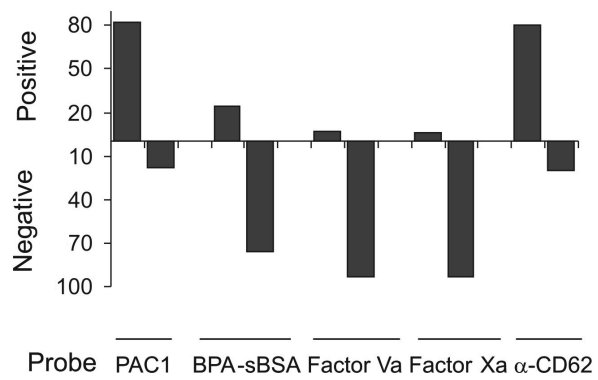

Figure 6 Heterogeneity in binding properties of PS-exposing platelets. Platelets in suspension were either unstimulated or stimulated with $50 \mathrm{ng} / \mathrm{mL}$ convulxin, $4 \mathrm{nM}$ thrombin and $2 \mathrm{mM} \mathrm{CaCl} \mathrm{Cor}_{2} 10$ minutes. Two-color flow cytometry was performed after staining with AF647-annexin A5 in combination with either $20 \mathrm{nM}$ AF488-factor Va, $100 \mathrm{nM}$ OG-factor Xa, $200 \mathrm{nM}$ OG-prothrombin or $1.25 \mu \mathrm{g} / \mathrm{mL}$ FITC- $\alpha-C D 62$ mAb. (A) Shown are dot plots of FL1 (AF488, OG) versus FL4 (AF647), representative of at least 4 experiments. (B) Characterization of the annexin A5 positive and annexin A5 negative fractions of platelets after 10 minutes of activation. Data are percentages of platelets staining positively (upside bars) or negatively (downside bars) with indicated probe: FITC-PAC1, AF532-streptavidin BPA-sBSA, AF488-factor Va, OG-factor Xa, or FITC- $\alpha-C D 62$. Data are representative for 4 independent experiments. 
prothrombin, whereas the annexin A5-positive platelets showed increased binding of these coagulation factors by $2.7,3.1$ and 2.0 fold, respectively (Figure $6 \mathrm{~A}$ ). In contrast, both populations of activated platelets were similarly high in CD62 expression.

For further analysis of these populations of AF647-annexin A5 positive and negative platelets, threshold levels of green fluorescence were set to indicate activationinduced binding of labeled antibodies and coagulation factors (Figure 6B). Comparison showed that hardly any of the PS-exposing (annexin A5-positive) platelets bound PAC1, while only a minority bound BPA-sBSA (probing coated platelets). In contrast, a large fraction of the PS-exposing platelets had increased binding of factor $\mathrm{Va}$, factor $\mathrm{Xa}$ and anti-CD62 mAb. On the other hand, the PS-negative platelets preferentially bound PAC1, anti-CD62, and to a moderate extent PBA-sBSA, but they were low in factor Va and factor Xa binding. Taken together, these data provide strong indications that platelets in a thrombus are segregated into aggregates that bind fibrin(ogen), PAC1 and BPA-sBSA and, at the other hand, patches of PS-exposing platelets with increased binding of all components of the prothrombinase complex (factor $\mathrm{Va}$, factor $\mathrm{Xa}$, and prothrombin) at the expense of integrin activation.

\section{Tyrosine phosphorylation state regulates platelet heterogeneity}

The observation that in platelets stimulated by convulxin and thrombin, $\alpha \operatorname{llb} \beta 3$ inactivation is linked to PS exposure may point to the involvement of a common signaling

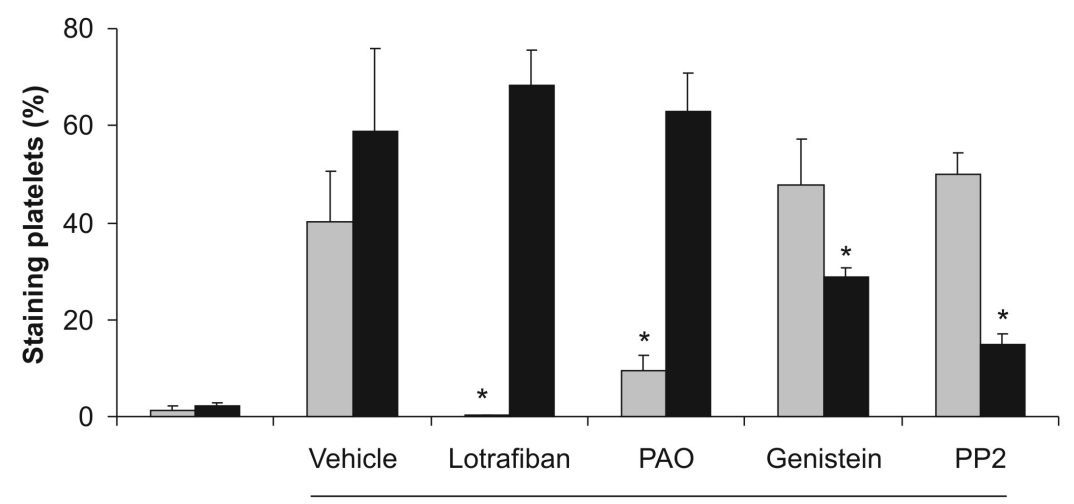

Unstimulated

Stimulated

Figure 7 Modulation of protein tyrosine phosphorylation alters integrin activation and PS exposure. Human washed platelets were stimulated with $50 \mathrm{ng} / \mathrm{mL}$ convulxin and $4 \mathrm{nM}$ thrombin in the presence of $2 \mathrm{mM} \mathrm{CaCl}_{2}$. The cells were pre-incubated for 10 minutes, as indicated, with vehicle, $200 \mu \mathrm{M}$ phenylarsine oxide (PAO), $100 \mu \mathrm{M}$ genistein, $20 \mu \mathrm{M}$ PP2, or $10 \mu \mathrm{M}$ lotrafiban. Co-labeling was with a mixture of FITC-PAC1 and AF647-annexin A5. Data are expressed as percentages of platelets staining with FITC-PAC1 (grey bars) or OG-annexin A5 (black bars). Mean \pm SD ( $n=4),{ }^{*} p<0.05$ compared to stimulation in the presence of vehicle. 
factor.

To investigate this further, platelets in suspension were pretreated with the $\alpha \operatorname{llb} \beta 3$ blocker, lotrafiban ${ }^{17}$, prior to stimulation with convulxin/thrombin. Lotrafiban treatment abolished PAC1 binding, while annexin A5 binding remained high (Figure 7), suggesting that integrin activation does not regulate PS exposure. Because both collagen and thrombin receptors activate platelet tyrosine kinases, we then investigated the effects of modulation of the tyrosine phosphorylation state. Pretreatment of platelets with the protein tyrosine phosphatase inhibitor, phenylarsine oxide (PAO), resulted in increased tyrosine phosphorylation (not shown), which was accompanied by substantially reduced PAC1 binding and unchanged PS exposure (Figure 7). By contrast, platelet pre-incubation with the general protein tyrosine kinase inhibitor genistein or the Src-kinase inhibitor PP2 left PAC1 binding virtually unchanged, while

A

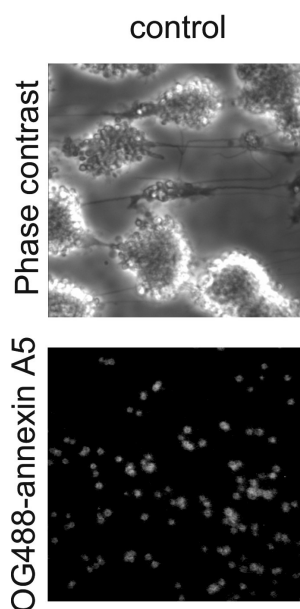

$7.2 \pm 4.1 \%$ lotrafiban
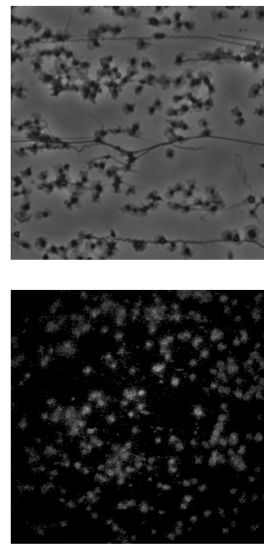

$9.3 \pm 4.7 \%$
B

control lotrafiban

175

83

62

47.5

32.5

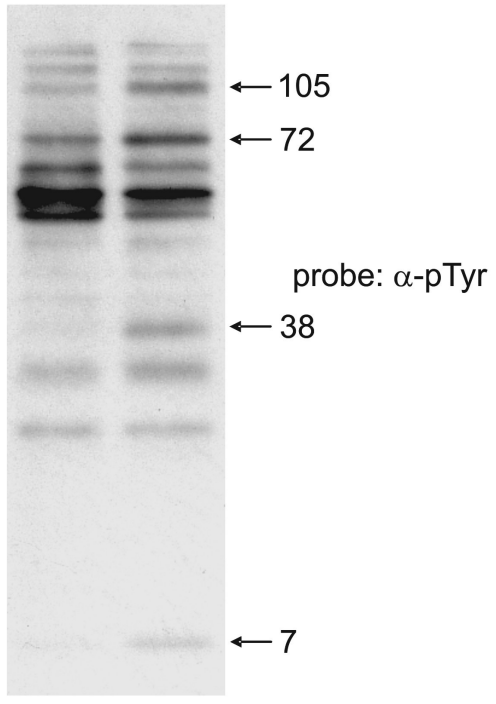

reprobe: $\alpha$-actin

Figure 8 Role of integrin $\alpha$ llb $\beta 3$ in tyrosine phosphorylation of collagen-adherent platelets. Human blood pre-treated with vehicle (control) or $10 \mu \mathrm{M}$ lotrafiban was flowed over collagen for 4 minutes at a shear rate of $1000 \mathrm{~s}^{-1}$, and stained with OG488-annexin A5. Numbers below images indicate mean surface area coverage \pm SD. (A) Representative phase-contrast $(120 \times 120 \mu \mathrm{m})$ and fluorescence $(150 \times 150 \mu \mathrm{m})$ images. (B) Flow chambers were perfused with lysis buffer to remove adherent platelets and lysates (equalized as far as possible for protein quantity) were run on a SDSPAGE gel, transferred to PVDF and blotted for phosphotyrosine using mAb 4G10, (C) then stripped and re-probed for actin using mAb AC-40. Representative data of 2-4 experiments. Note the low actin staining for the lotrafiban lane, indicating the increased phosphorylation of 7, 38, 72 and 105 $\mathrm{kDa}$ proteins is underestimated for this gel. 
these compounds reduced the number of PS-exposing cells. Yet, in all conditions, the majority of the platelets that bound PAC1 did not bind annexin A5, and vice versa. Together, this indicated that a prolonged high tyrosine phosphorylation state (e.g., by Src kinase activity) reduced integrin activation, but stimulated PS exposure.

The importance of protein tyrosine phosphorylation was further examined in flow studies (in the absence of coagulation). Pre-incubation of blood with lotrafiban increased the number of PS-exposing platelets, but reduced the total number of adherent platelets, because aggregation was abolished (Figure 8). Gel electrophoresis of the platelet proteins, followed by immunoblotting with anti-phosphotyrosine 4G10 mAb,
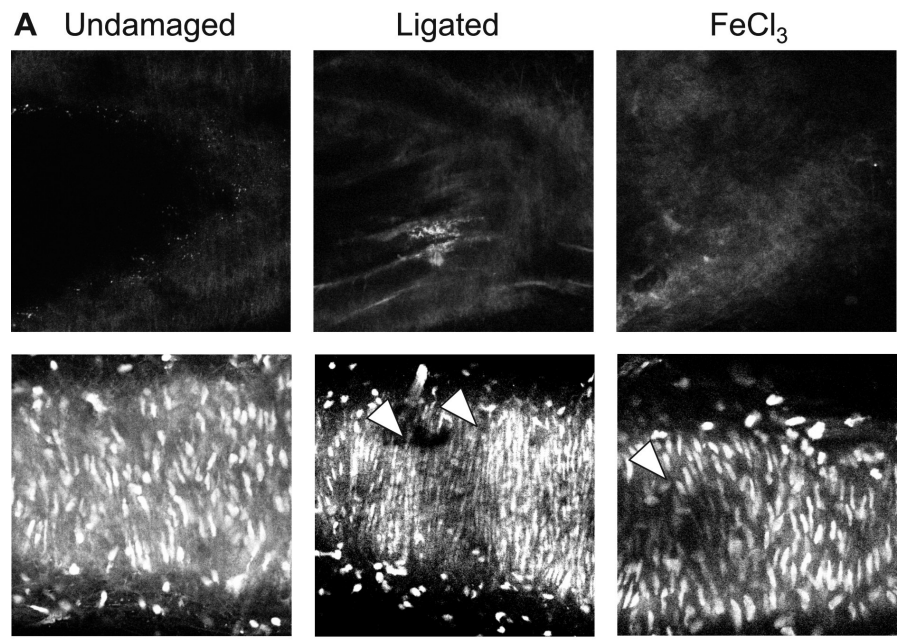

\section{B Ligated - 3D reconstructions}
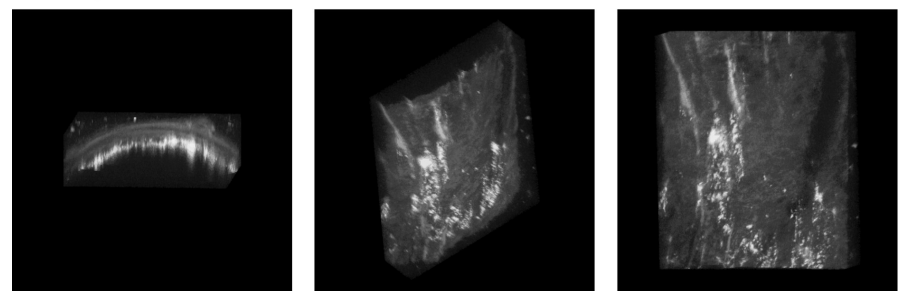

Figure 9 Heterogeneity in arterial thrombi induced by carotid ligation or by $\mathrm{FeCl}_{3}$ application. Mice were infused with OG-fibrinogen and AF568-annexin A5 (200 $\mu \mathrm{g}$ each). Left panels: undamaged control carotid artery. Middle panels: One carotid artery was damaged by tight ligation at the bifurcation for 5 minutes to induce vascular damage. Right panels: in another animal, the carotid artery was damaged by local application of saturated $\mathrm{FeCl}_{3}$. Thrombus formation proceeded for 10 minutes, after which fluorescence inside the arteries was recorded by TPLSM. (A) Upper row: images of fibrin(ogen) and annexin A5 fluorescence taken on the luminal side of the vessel wall. Note distinct patches of green and red fluorescence. Second row: images of Syto44 fluorescence at cross section through the vessel wall. Arrow heads indicate absence of cell nuclei at sites of damage. (B) Three-dimensional reconstructions of fibrin(ogen) and annexin A5 fluorescence in the ligated artery: side view through vessel wall, turned view, and view from inside of vessel lumen. Images are $206 \times 206 \mu \mathrm{m}$. 
indicated that lotrafiban treatment specifically increased the tyrosine phosphorylation levels of proteins of about 7, 38, 72 and $105 \mathrm{kDa}$ (Figure 8). More direct evidence for an increased tyrosine phosphorylation in PS-exposing platelets was obtained by staining the collagen-bound platelets on coverslips with FITC-4G10 mAb. Comparison of brightfield and confocal fluorescent images indicated that, typically, the single (AF647-annexin A5 positive) platelets were more fluorescent than adjacent platelets in aggregates. Quantitative analysis showed that fluorescence levels per pixel of the single cells were $2.4 \pm 0.8(n=7)$ fold higher, in comparison to pixels with aggregated platelets. Lotrafiban treatment maintained this high FITC-4G10 staining. Accordingly, high tyrosine phosphorylation levels accompany PS exposure, but not integrin activation.

\section{Heterogeneity in fibrin(ogen) binding and PS exposure of thrombi formed in vivo}

A key question is how the platelet heterogeneity as observed in thrombi formed in vitro relates to the in vivo situation. To investigate this, anesthetized mice were coinfused with fluorescently labeled OG-fibrinogen and AF568-annexin A5. Thereafter damage to the carotid arteries was provoked using two different techniques. In the first method, the artery was ligated, which results in mechanical exposure of subendothelial collagen ${ }^{30}$. Alternatively, $\mathrm{FeCl}_{3}$ was applied locally to the vessel, which causes endothelial denudation by free radical formation ${ }^{26,31}$. After in vivo thrombus formation for 10 minutes, the injured and control (undamaged) vessels of the animals were scanned using the high penetration power of TPLSM. Typically, fluorescence from both probes was detected only at sites of ligation or $\mathrm{FeCl}_{3}$ application, and was absent in control arteries. Optical cross-sections showed local spots of OG-fibrin(ogen) at the wall-lumen interface, which to a small extent overlapped with spots of AF568-annexin A5 (Figure 9A, first row). Three-dimensional reconstruction of the images at thrombotic sites showed distinct patches of fluorescent fibrin(ogen) and annexin A5, again only at the damaged vascular lumen (Figure 9B). After scanning, the still intact arteries were post-stained for vessel wall cells with the nuclear stain Syto-44, and then rescanned. Optical crosssectioning demonstrated absence of Syto-44 fluorescence at the sites of ligation or $\mathrm{FeCl}_{3}$ application, thus confirming the local damaging effect of the prothrombotic interventions (Figure 9A, second row). Together, these data show that fibrin(ogen)-rich and annexin A5-binding domains appear at adjacent but distinct locations during in vivo thrombus formation. 


\section{Discussion}

The present data indicate that during the thrombus-forming process different clusters of platelets contribute to aggregate formation and to coagulant activity, which points to a clear spatial separation of these two key functions of platelets. In sheardependent thrombus formation triggered by collagen (GPVI) and thrombin receptors, we distinguish at least two, and likely even three microdomains of activated platelets: (i) platelets packed in fibrin-containing aggregates (clots) with activated $\alpha$ llb $\beta 3$ integrin at their surface; (ii) strings of non-aggregated platelets which are low in activated $\alpha$ llb $\beta 3$, but expose PS and efficiently bind the components of the prothrombinase complex; (iii) platelets binding serotonin probes in addition to factor $\mathrm{Va}$, which partly overlap with the aggregated platelets.

The microdomains of aggregated platelets, rich in fibrin(ogen) under condition of thrombin generation, were most readily distinguished by high binding of PAC1 mAb, which stains activated $\alpha \operatorname{llb} \beta 3$ integrins. Part of these platelets expressed CD62 at their surface, indicating secretion. Typically, as long as aggregated, these platelets did not bind annexin A5 and, thus, did not expose procoagulant PS. In both confocal microscopy and flow cytometry, the annexin A5 negative platelets showed low binding to coagulation factors $\mathrm{Va}$ and $\mathrm{Xa}$ and prothrombin.

The second type of microdomain consists of mostly bleb-shaped platelets, which often appear as strings at the edge of clots. Visual inspection and also overlap analysis of two-color fluorescence images pointed to a clear separation of the annexin A5-binding platelets, exposing PS, from the fibrinogen- and PAC1-binding platelets in aggregates or clots. The round morphology and lack of pseudopods is well compatible with the low integrin activation state and thus diminished adhesion. Likely, these platelets play an important role in thrombotic thrombin generation, given the increased binding of factor $\mathrm{Va}$, factor $\mathrm{Xa}$ and prothrombin. For these studies, we used fluorescent labeled factor Va, which had fully kept its co-factor function in prothrombinase activity; and active site-labeled factor Xa and prothrombin, with proven unaltered binding characteristics ${ }^{19}$.

The appearance of single, bleb-shaped, PS-exposing platelets upon interaction of platelets with collagen via GPVI was already reported earlier ${ }^{24,25}$. However, a novel finding is that this platelet response becomes much more frequent during perfusion of blood in the presence of thrombin generation and coagulation. In this case, strings of platelets often located around clots jointly transform into PS-exposing cells. The result is that thrombi develop into a patched structure with microdomains of platelet/fibrin aggregates, alternated with loose clusters of PS-exposing platelets. It is tempting to 
suggest that the collagen-bound platelets in the first phase of PS exposure contribute to initial phases of thrombin generation, while the procoagulant platelets around clots help to propagate thrombin production. A similar patched structure of fibrin(ogen)- and annexin A5-binding cells is observed by TPLSM imaging of the thrombi inside murine arteries, generated following two different models of vascular damage in vivo. Thus, we hypothesize that the microdomain organization with separate aggregated/clotted and coagulation-active platelets is functionally relevant to arterial thrombosis in humans.

The experiments distinguish a third subpopulation of platelets, but with less characteristic binding properties. Using BPA-sBSA as a probe that specifically detects serotonin binding sites, we observed appreciable labeling of platelet aggregates and to a smaller extent to single, PS-exposing platelets. In fact, the Pearson correlation coefficient $R_{r}$ of BPA-sBSA versus fibrinogen staining is 0.54 , i.e. higher than the $R_{r}$ of BPA-sBSA versus annexin $A 5$ labeling of 0.21 . The fact that aggregates were labeled with BPA-sBSA is not surprising, because the initial description of 'coated' (or COAT) platelets referred to platelets that are covered with serotonin-derivatized proteins such as fibrin(ogen) and thrombospondin in association with the granular proteins vWF, factor $V$, and fibronectin ${ }^{14}$, all of which are present on platelet aggregates formed on a collagen surface $^{26,32,33}$. On the other hand, current literature is inconsistent in the description of coated platelets - e.g. as formed by convulxin/thrombin stimulation -, which may coincide with PS-exposing platelets ${ }^{15}$, or with fibrin(ogen)-binding platelets ${ }^{16}$. The present data can resolve this discrepancy by showing that BPA-sBSA binds aggregates (in thrombi) with a certain preference, but also to some extent PS-exposing platelets (in suspensions).

Recent studies have suggested that platelet-secreted proteases are involved in the formation of subpopulations of coagulation-active platelets. One proposal is that extracellular transglutaminases like factor XIIla contribute to this platelet response by cross-linking membrane surface proteins with secretion factors, e.g. via serotonin conjugation to form coated platelets ${ }^{12,13}$. Also, extracellular or intracellular calpain activity may contribute to development of the procoagulant platelet phenotype ${ }^{4,12}$. In our hands, inhibition of transglutaminases (MDC) or calpain (calpeptin) had only little effect on PS exposure, while only MDC had a small inhibitory effect on integrin inactivation in convulxin/thrombin-stimulated platelets. This indicated that transglutaminases did not play a major role in the regulation of platelet procoagulant activity, which is in line with a recent report that the binding of secretory proteins and annexin A5 to platelets on collagen requires GPVI/FcR $\gamma$-chain activity, but not factor $\mathrm{XIII}^{16}$. 
Therefore, we investigated the possibility that an intracellular signaling pathway rather than an extracellular mechanism is responsible for platelet heterogeneity in thrombus formation. Reason for this is the knowledge that GPVI alone or in combination with thrombin receptor stimulation causes a potent $\mathrm{Ca}^{2+}$ response, which is a prerequisite for PS exposure in both human and murine platelets ${ }^{4,12,24,34}$. The current data provide evidence that protein tyrosine kinase activity is stimulatory to PS exposure (likely via stimulation of the GPVI - phospholipase C- $\gamma 2$ pathway), but inhibitory to persistent integrin $\alpha \mathrm{llb} \beta 3$ activation. This is concluded from the relatively high tyrosine phosphorylation state of PS-exposing, PAC1-negative platelets on collagen as probed with fluorescent $4 \mathrm{G} 10 \mathrm{mAb}$, and also from the reducing effect of tyrosine phosphatase inhibition on PAC1 binding with unchanged PS exposure. Further support came from perfusion experiments in the presence of an $\alpha \mathrm{llb} \beta 3$ antagonist, which increased the tyrosine phosphorylation of several platelet proteins along with the number of PSexposing platelets on collagen.

In summary, we conclude that in collagen- and thrombin-induced thrombus formation, differences in intracellular signaling state controlled by $\alpha$ llb $\beta 3$ activation accomplish the separation of microdomains of aggregated and PS-exposing platelets. Typically, in PS-exposing platelets, down-regulation of integrin binding is accompanied by up-regulation of coagulation factor binding. These results point to a balance, in which coagulant activity suppresses integrin activation, while conversely, aggregate formation reduces the procoagulant activity of platelets.

\section{Acknowledgments}

We thank drs. R. Megens and W. Engels for expert assistance with TPLSM. We acknowledge dr. G. Dale (Dept. of Medicine, Health Science Center, Oklahoma) for the kind gift of BPA-sBSA. This work was supported by the Netherlands Heart Foundation (2002-B014). 


\section{References}

1. Reverter JC, Beguin S, Kessels H, Kumar R, Hemker HC, Coller BS. Inhibition of plateletmediated, tissue factor-induced thrombin generation by the mouse/human chimeric 7E3 antibody. Potential implications for the effect of c7E3 Fab treatment on acute thrombosis and "clinical restenosis". J Clin Invest. 1996;98:863-874.

2. Heemskerk JWM, Kuijpers MJE, Munnix ICA, Siljander PRM. Platelet collagen receptors and coagulation. Trends Cardiovasc Med. 2005;15:86-92.

3. Zwaal RFA, Schroit AJ. Pathophysiologic implications of membrane phospholipid assymetry in blood cells. Blood. 1997;89:1121-1132.

4. Siljander P, Farndale RW, Feijge MAH, Comfurius P, Kos S, Bevers EM, Heemskerk JWM. Platelet adhesion enhances the glycoprotein VI-dependent procoagulant response: involvement of p38 MAP kinase and calpain. Arterioscler Thromb Vasc Biol. 2001;21:618-627.

5. Munnix ICA, Harmsma M, Giddings JC, Collins PW, Feijge MAH, Comfurius P, Heemskerk JWM, Bevers EM. Store-mediated calcium entry in the regulation of phosphatidylserine exposure in blood cells from Scott patients. Thromb Haemost. 2003;89:687-695.

6. Keuren JFW, Wielders SJ, Ulrichts H, Hackeng T, Deckmyn H, Heemskerk JWM, Bevers E, Lindhout T. Synergistic effect of thrombin on collagen-induced platelet procoagulant activity is mediated through protease-activated receptor-1. Arterioscler Thromb Vasc Biol. 2005;25:1499-1505.

7. Butenas S, van 't Veer C, Mann KG. 'Normal' thrombin generation. Blood. 1999;94:2169-2178.

8. Monroe DM, Hoffman M, Roberts HR. Platelets and thrombin generation. Arterioscler Thromb Vasc Biol. 2002;22:1381-1389.

9. London FS, Marcinkiewicz M, Walsh PN. A subpopulation of platelets responds to thrombinor SFLLRN-stimulation with binding sites for factor IXa. J Biol Chem. 2004;279:19854-19859.

10. Kempton CL, Hoffman M, Roberts HR, Monroe DM. Platelet heterogeneity: variation in coagulation complexes on platelet subpopulations. Arterioscler Thromb Vasc Biol. 2005;25:861-866.

11. Panteleev MA, Ananyeva NM, Greco NJ, Ataullakhanov FI. Two subpopulations of thrombinactivated platelets differ in their binding of the components of the intrinsic factor Xa-activating complex. J Thromb Haemost. 2005;3:2545-2553.

12. Kulkarni S, Jackson SP. Platelet factor XIII and calpain negatively regulate integrin allbb3 adhesive function and thrombus growth. J Biol Chem. 2004;279:30697-30706.

13. Dale GL, Friese P, Batar P, Hamilton SF, Reed GL, Jackson KW, Clemetson KJ, Alberio L. Stimulated platelets use serotonin to enhance their retention of procoagulant proteins on the cell surface. Nature. 2002;415:307-315.

14. Szasz R, Dale GL. Thrombospondin and fibrinogen bind serotonin-derivatized proteins on COAT-platelets. Blood. 2002;100:2827-2831.

15. Dale GL. Coated-platelets: an emergic component of the procoagulant response. J Thromb Haemost. 2005;3:2185-2192.

16. Jobe SM, Leo L, Eastvold JS, Dickneite G, Ratliff TL, Lentz SR, Di Paola J. Role of FcR $\gamma$ and factor XIIla in coated platelet formation. Blood. 2005;106:4146-4151.

17. Auger JM, Kuijpers MJE, Senis YA, Watson SP, Heemskerk JWM. Adhesion of human and mouse platelets to collagen under shear: a unifying model. FASEB J. 2005;19:825-827.

18. Bock PE. Active-site-selective labeling of blood coagulation proteinases with fluorescence probes by the use of thioester peptide chloromethyl ketones. Properties of thrombin derivatives as reporters of prothrombin fragment 2 binding and specificity of the labeling approach for other proteinases. J Biol Chem. 1992;267:14974-14981.

19. Panizzi P, Friedrich R, Fuentes-Prior P, Kroh HK, Briggs J, Tans G, Bode W, Bock PE. Novel fluorescent prothrombin analogs as probes of staphylocoagulase-prothrombin interactions. J Biol Chem. 2006;281:1169-1178. 
20. Nicolaes GA, Tans G, Thomassen MCLGD, Hemker HC, Pabinger I, Varadi K, Schwarz HP, Rosing J. Peptide bond cleavages and loss of functional activity during inactivation of factor Va and factor VaR506Q by activated protein C. J Biol Chem. 1995;270:21158-21166.

21. Nieswandt B, Brakebusch C, Bergmeier W, Schulte V, Bouvard D, Mohtari-Nejad R, Lindhout T, Heemskerk JWM, Zirngibl H, Fässler R. Glycoprotein VI but not $\alpha 2 \beta 1$ integrin is essential for platelet interaction with collagen. EMBO J. 2001;20:2120-2130.

22. Van Zandvoort M, Engels W, Douma K, Beckers L, oude Egbrink M, Daemen M, Slaaf DW. Two-photon microscopy for imaging of the (atherosclerotic) vascular wall. J Vasc Res. 2004;41:54-63.

23. McCarty OJ, Larson MK, Auger JM, Kalia N, Atkinson BT, Pearce AC, Ruf S, Henderson RB, Tybulewicz VL, Machesky LM, Watson SP. Rac1 is essential for platelet lamellipodia formation and aggregate stability under flow. J Biol Chem. 2005;280:39474-39484.

24. Kuijpers MJE, Schulte V, Bergmeier W, Lindhout T, Brakebusch C, Offermanns S, Fässler R, Heemskerk JWM, Nieswandt B. Complementary roles of glycoprotein VI and $\alpha 2 \beta 1$ integrin in collagen-induced thrombus formation in flowing whole blood ex vivo. FASEB J. 2003;17:685687.

25. Siljander PRM, Munnix ICA, Smethurst PA, Deckmyn H, Lindhout T, Ouwehand WH, Farndale RW, Heemskerk JWM. Platelet receptor interplay regulates collagen-induced thrombus formation in flowing human blood. Blood. 2004;103:1333-1341.

26. Munnix ICA, Strehl A, Kuijpers MJE, Auger JM, van der Meijden PEJ, van Zandvoort MAM, oude Egbrink MGA, Nieswandt B, Heemskerk JWM. The glycoprotein VI-phospholipase C $\gamma 2$ signaling pathway controls thrombus formation induced by collagen and tissue factor in vitro and in vivo. Arterioscler Thromb Vasc Biol. 2005;25:2673-2678.

27. Poole A, Gibbins JM, Turner M, van Vugt MJ, van de Winkel JGJ, Saito T, Tybulewicz VLJ, Watson SP. The Fc receptor $\gamma$-chain and the tyrosine kinase Syk are essential for activation of mouse platelets by collagen. EMBO J. 1997;16:2333-2341.

28. Kuijpers MJE, Nieuwenhuys CMA, Feijge MAH, Giesen PLA, oude Egbrink MGA, Heemskerk JWM. Regulation of tissue factor-induced coagulation and platelet aggregation in flowing whole blood. Thromb Haemost. 2005;93:97-105.

29. Tans G, Rosing J, Thomassen MCLGD, Heeb MJ, Zwaal RFA, Griffin JH. Comparison of anticoagulant and procoagulant activities of stimulated platelets and platelet-derived microparticles. Blood. 1991;77:2641-2648.

30. Massberg S, Gawaz M, Grüner S, Schulte V, Konrad I, Zohlnhofer D, Heinzmann U, Nieswandt B. A crucial role of glycoprotein VI for platelet recruitment to the injured arterial wall in vivo. J Exp Med. 2003;197:41-49.

31. Ni H, Denis CV, Subbarao S, Degen JL, Sato TN, Hynes RO, Wagner DD. Persistence of platelet thrombus formation in arterioles of mice lacking both von Willebrand factor and fibrinogen. J Clin Invest. 2000;106:385-392.

32. Ruggeri ZM. Platelets in atherothrombosis. Nat Med. 2002;8:1227-1234.

33. Lecut C, Schoolmeester A, Kuijpers MJE, Broers JLV, van Zandvoort MAMJ, Vanhoorelbeke $\mathrm{K}$, Deckmyn H, Jandrot-Perrus M, Heemskerk JWM. Principal role of glycoprotein VI in $\alpha 2 \beta 1$ and $\alpha \mathrm{llb} \beta 3$ activation during collagen-induced thrombus formation. Arterioscler Thromb Vasc Biol. 2004;24:1727-1733.

34. Heemskerk JWM, Vuist WMJ, Feijge MAH, Reutelingsperger CPM, Lindhout T. Collagen but not fibrinogen surfaces induce bleb formation, exposure of phosphatidylserine and procoagulant activity of adherent platelets. Blood. 1997;90:2615-2625. 


\section{Chapter 8}

General discussion 
The majority of cardiovascular diseases involve undesired thrombus formation and embolisation following vascular damage or plaque rupture. The thromboembolic process is known to be driven by platelet activation and the coagulation system. As these processes are of major importance in both arterial and venous thrombosis, clear understanding of the interactions between these two processes will be important for a successful fight of cardiovascular diseases. The overall goal of the studies presented in this thesis is to identify and study the interaction between platelet activation and coagulation at different levels of complexity. Part of the investigations considers subcellular and cellular aspects of the signaling pathways of platelets that contribute to the generation of their procoagulant activity. Other experiments focus on the intercellular processes defining the formation of multi-platelet thrombi formed in vitro under conditions of blood flow and coagulation. Furthermore, in vivo mouse models of experimental intravascular thrombosis have been developed and used to assess the role of procoagulant platelets in coagulation and the differences among platelets in a thrombus. The signaling receptor for collagen, glycoprotein VI, appears to play a key role in this platelet response.

\section{Signaling pathways of glycoprotein VI to procoagulant activity}

Knowing that platelet-collagen interaction via glycoprotein VI (GPVI) can induce procoagulant activity, we were interested to determine which processes operating alongside and downstream of GPVI contribute to the procoagulant response under physiologically relevant conditions. Chapter 4 discusses the important question how the other collagen receptor, integrin $\alpha 2 \beta 1$, contributes to the procoagulant function of GPVI in human blood flowing at arterial shear rate. Using a newly generated single-chain phage antibody fragment, $10 \mathrm{~B} 12$, we were able to demonstrate that GPVI is the exclusive receptor implicated in all collagen-induced activation responses, such as $\mathrm{Ca}^{2+}$ signaling, aggregate formation and phosphatidylserine (PS) exposure. Inhibition of $\alpha 2 \beta 1$ with specific peptides or antibodies reveals that this integrin does contribute to the regulation of $\mathrm{Ca}^{2+}$ signaling, platelet aggregation and $\mathrm{PS}$ exposure, but only by enforcement of the responses evoked by GPVI. Inhibitory experiments also show that blocking of another adhesive receptor, the GPIb-V-IX complex which binds von Willebrand factor (vWF), has only little effect on PS exposure. These results thus indicate that only two of the three human platelet receptors for vWF/collagen are involved in the procoagulant response. However, in mice GPIb interaction with vWF was found to enhance GPVI-induced PS exposure, along with stimulation of the rise in 
$\left[\mathrm{Ca}^{2+}\right]_{\mathrm{i}}^{1}$. The reason for this discrepancy is unclear. However, in the human system we have not investigated the contribution of GPIb to procoagulant activity at shear rates higher than $1000 \mathrm{~s}^{-1}$, at which more prominent GPIb effects are expected ${ }^{1}$.

During the progress of this work, several other studies with human and mouse blood with different anti-GPVI antibodies and GPVI-deficient mouse models indicated that GPVI plays a key role in collagen-induced thrombus formation under flow; GPVI thus appears to be the principal collagen receptor causing $\mathrm{Ca}^{2+}$ signaling, secretion, integrin activation and procoagulant activity ${ }^{2-4}$. In the present context it is of interest that the data of chapter 4 , and also those of other papers, demonstrate a direct relation between the GPVI-evoked rises in intracellular $\mathrm{Ca}^{2+}$ levels and the extent of phosphatidylserine (PS) exposure by platelets. Together, this supports the early suggestion that the PS-exposing mechanism ('scramblase') is directly or indirectly regulated by a strong elevation in intracellular $\mathrm{Ca}^{2+}$ concentration ${ }^{5}$.

The murine studies described in chapter 5 , are of particular interest for the signal transduction route by which GPVI is capable to induce PS exposure in the process of thrombus formation. Using mice deficient in FcR $\gamma$-chain, the adaptor protein LAT or phospholipase $\mathrm{C} \gamma 2$ (PLC $\gamma 2$ ), we show that these signaling proteins, which are downstream of GPVI, are all required for PS exposure. In addition, the essential role of Src-family kinases, likely Lyn, in this process was examined by using the specific inhibitor PD173952. It is known that the GPVI/Lyn/LAT signaling pathway is the most important mechanism for tyrosine phosphorylation and activation of PLC $\gamma 2$ via protein assembly in the so-called LAT signallosome ${ }^{6,7}$. The same research indicated that Syk is the principal tyrosine kinase mediating phosphorylation of both LAT and PLC $\gamma 2^{6,7}$. It was also known that genistein, which is an inhibitor of Syk kinase, suppresses collageninduced PS exposure ${ }^{8}$, which thus makes it quite likely that also Syk is an essential component of the signaling route from GPVI to PS exposure. However, as Syk deficient mice are not viable ${ }^{9}$, we have not been able to demonstrate this unequivocally. Interestingly, recent data using vital Syk -/- chimeras pointed to a novel signaling pathway of GPVI in supporting thrombin-induced activation, which operates independently of Src and Syk kinases ${ }^{10}$. In view of the current results, it is unlikely that this GPVI pathway is involved in procoagulant activity.

A number of other members of the LAT signallosome have been identified, which all act downstream of GPVI and Syk kinase, including the tyrosine kinases Btk and Tec, the G-protein-stimulating factors Vav1/3, and the adaptor proteins SLP-76 and Gads $^{7}$. Although we have not investigated involvement of these components, we predict that they will only play a role in PS exposure as far as operating upstream of PLC $\gamma 2$. 
Together, our data show that the role of GPVI in PS exposure is mediated via a relatively simple signaling pathway, consisting of Src kinase (Lyn), Syk and LAT, and resulting in activation of PLC $\gamma 2$ as a key intermediate step (Figure 1). This work thereby emphasizes the importance of PLC $\gamma 2$ in platelet activation ${ }^{7}$.

Activation of PLC $\gamma 2$ leads to production of inositol 1,4,5-trisphosphate ( $\operatorname{nnsP}_{3}$ ) and subsequent $\mathrm{Ca}^{2+}$ release from intracellular stores. In cell types other than platelets, the $\mathrm{PH}$ domain-containing PLC $\gamma$ isoforms bind to and are activated by phosphatidylinositol 3,4,5-trisphosphate $\left(\mathrm{PIP}_{3}\right)$, which is formed in the plasma membrane by phosphoinositide 3-kinase (PI3K) activity ${ }^{11}$. Therefore, the membrane-bound PLC $\gamma$ has easier access to its substrate, $\mathrm{PIP}_{2}$. Especially members of the class $1 \mathrm{~A} / \mathrm{B} \mathrm{PI} 3 \mathrm{~K}$ isoforms appear to be responsible for $\mathrm{PIP}_{3}$ formation ${ }^{12}$. Earlier work with platelets showed that GPVI activation is accompanied by incorporation of the class $1 \mathrm{~A}$ regulatory subunit $p 85 \alpha$ into the LAT signallosome ${ }^{13}$. We therefore investigated whether the GPVI pathway to $\mathrm{PLC} \gamma 2$ activation, $\mathrm{Ca}^{2+}$ signaling and PS exposure involves activity of one or

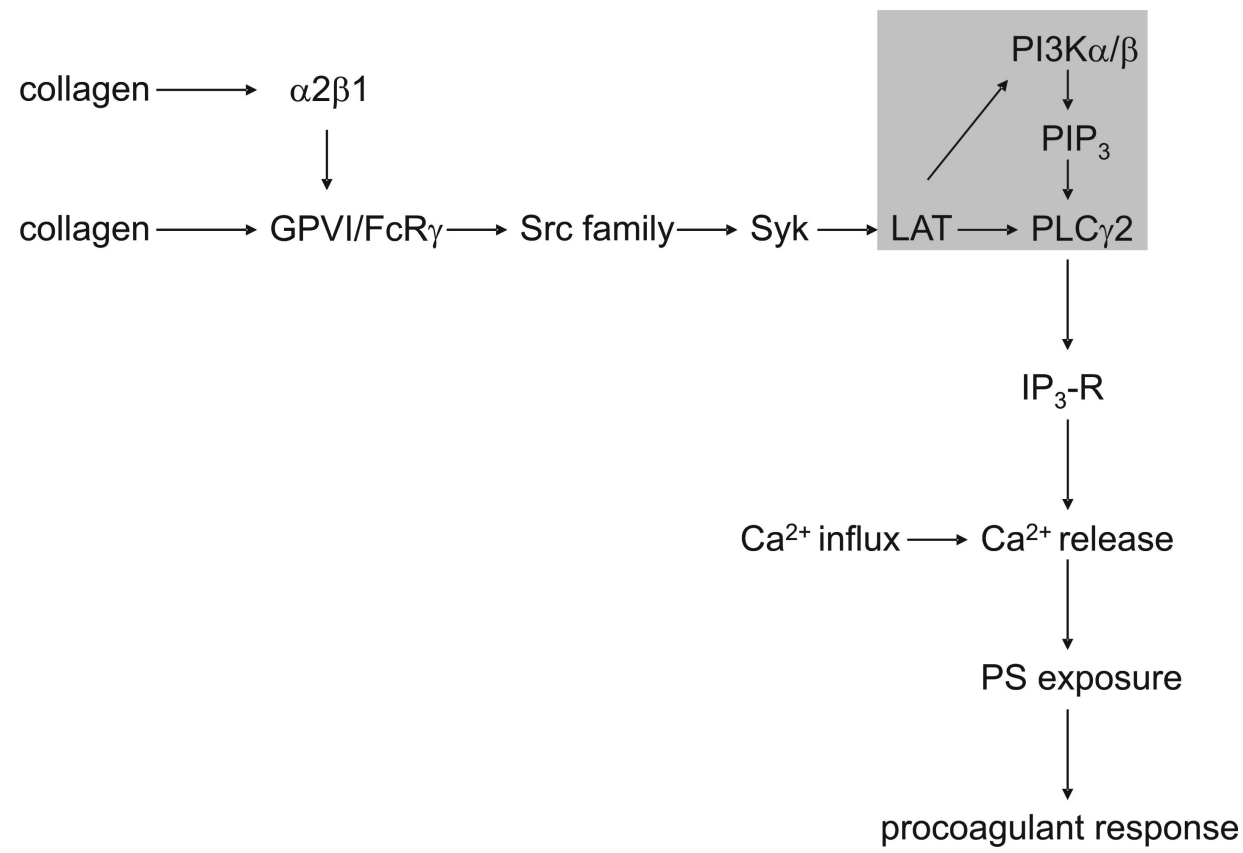

Figure 1 Overview of intracellular platelet signaling leading to procoagulant activity. The indicated GPVI pathway to PLC $\gamma 2$ activation is recognized as the key signaling mechanism for $\mathrm{Ca}^{2+}$-dependent PS exposure and procoagulant activity. Several signaling proteins cluster together in the LAT signallosome (grey box). The PI3K $\alpha$ and $\beta$ isoforms support in this platelet response, by enhancing $\mathrm{Ca}^{2+}$ mobilisation and subsequent store-mediated $\mathrm{Ca}^{2+}$ entry. 
more PI3K isozymes. Platelets contain various class IA ( $\alpha, \beta$ and $\delta)$ and class IB $(\gamma)$ PI3K isoforms ${ }^{14,15}$. However, some authors report that the expression of the p110 $\delta$ catalytic subunit is only limited ${ }^{16-18}$. For the study presented in chapter 3 , we used several newly developed inhibitors interacting with the catalytic subunits of the various PI3Ks, as well as mice lacking the $p 85 \alpha$ regulatory subunit (for class $1 \mathrm{~A}$ PI3Ks) and animals lacking the $\mathrm{p} 110 \gamma$ catalytic subunit (class $1 \mathrm{~B} \mathrm{PI} 3 \mathrm{~K} \gamma$ ). The overall results indicate that both the $\mathrm{p} 85 \alpha$ regulatory subunit and the catalytic $\mathrm{p} 110 \beta$ activity contribute significantly to $\mathrm{Ca}^{2+}$ signaling and PS exposure elicited by GPVI ligands. This contribution occurs via the classical $\mathrm{Ca}^{2+}$ pathway, i.e. by enhancing $\mathrm{Ca}^{2+}$ mobilization and subsequent storemediated $\mathrm{Ca}^{2+}$ entry (Figure 1). In our hands, the class $1 \mathrm{~A} \mathrm{PI} 3 \mathrm{~K} \delta$ and the class $1 \mathrm{~B} \mathrm{PI} 3 \mathrm{~K} \gamma$ do not seem to have a prominent role in this process.

For platelets it is known that deletion of the murine $p 85 \alpha$ regulatory subunit does not influence the expression of other type IA regulatory subunits ( $p 55 \alpha, p 50 \alpha$ and $\mathrm{p} 85 \beta$ ); however, it leads to a major reduction in the level of the $\mathrm{p} 110 \alpha$ catalytic subunit, along with greatly reduced $\mathrm{p} 110 \beta$ and $\delta$ expression ${ }^{16,19,20}$. Recent experiments with $\mathrm{PI} 3 \mathrm{~K} \delta$-deficient mice pointed to only a minor but detectable role for the $\delta$ isoform in mediating platelet activation by collagen ${ }^{21}$. Furthermore, both $\mathrm{PI} 3 \mathrm{~K} \beta$ and $\gamma$ isoforms were found to control ADP-dependent platelet activation processes ${ }^{12,17,22}$. Together with the present results, this indicates that in mouse as well as human platelets particularly the $\mathrm{PI} 3 \mathrm{~K} \alpha$ and $\beta$ isoforms, acting via $\mathrm{p} 85 \alpha$, are involved in GPVI-induced activation, while the $\beta$ and $\gamma$ isoforms rather act downstream of ADP receptors.

GPVI-induced PLC $\gamma 2$ activation produces $\operatorname{Ins}_{3}$, which opens the $\operatorname{InsP}_{3}$ receptor $\mathrm{Ca}^{2+}$ channels to release $\mathrm{Ca}^{2+}$ from intracellular stores. It is recognised that intracellular $\mathrm{Ca}^{2+}$ mobilisation, by itself, is insufficient for full platelet activation. The process of storeoperated $\mathrm{Ca}^{2+}$ entry, which causes $\mathrm{Ca}^{2+}$ influx from the extracellular medium, is required to reach the high cytosolic $\mathrm{Ca}^{2+}$ concentration needed for $\mathrm{PS}$ exposure ${ }^{5,8,23}$. One research group provided evidence that the store-operated $\mathrm{Ca}^{2+}$ entry is impaired in a French Scott patient and, thereby, suppresses surface exposure of PS on activated platelets and other blood cells ${ }^{24,25}$. Chapter 2 describes the unexpected observation that the $\mathrm{Ca}^{2+}$ responses in both platelets and immortalized B-cells from two different Scott patients (including the propositus patient) are unaltered in comparison to cells from control subjects. On the other hand, PS exposure in response to GPVI is strongly reduced in cells from these patients. These results indicate that the impaired lipid scrambling in the Scott cells can not be ascribed to alterations in $\mathrm{Ca}^{2+}$ release from intracellular stores or subsequent $\mathrm{Ca}^{2+}$ entry. Unfortunately, we have not been able to 
make a direct comparison with cells derived from the French Scott patient. Although the reason for the discrepancy with the literature is unclear, it is noteworthy that the diminished $\mathrm{Ca}^{2+}$ influx in the cells from the French patient was only detected with specific time-dependent protocols to measure $\mathrm{Ca}^{2+}$ influx ${ }^{24}$ and, therefore, could be due to subtle signaling changes distantly from the $\mathrm{Ca}^{2+}$ influx channels. Alternatively, the differences might reflect variants of the Scott syndrome, which is still not genetically characterised.

Platelets from (our) Scott patients are interesting, because these are so far the only platelet types, in which high $\mathrm{Ca}^{2+}$ does not automatically lead to PS exposure. This implies that the defect in these patients should lay downstream of $\mathrm{Ca}^{2+}$ signal generation and, moreover, that $\mathrm{Ca}^{2+}$ entry channels themselves are not determinants for PS exposure. This was confirmed by the finding that the expression pattern of Trpc channels, which are strong candidates of the channels responsible for store-regulated $\mathrm{Ca}^{2+}$ entry, is similar in the cells from Scott patients and control subjects (I. Munnix, unpublished results). A major drawback in the field is that the molecular identity of the components (enzymes, channels?) that are responsible for the lipid scrambling implicated in PS exposure is unknown. After many efforts, a phospholipid scramblase has been identified ${ }^{26}$, but this enzyme does not mediate PS exposure in platelets ${ }^{27}$. It is shown that in addition to $\mathrm{Ca}^{2+}$ channels, also Gardos-type of $\mathrm{K}^{+}$channels play a role in $P S$ exposure ${ }^{28}$. Other, newly identified proteins involved in store-regulated $\mathrm{Ca}^{2+}$ entry are the ORAI channels ${ }^{29}$ and STIM1, which is a calcium sensor for $\mathrm{Ca}^{2+}$ channels and couples $\mathrm{Ca}^{2+}$ stores to the plasma membrane ${ }^{30}$. STIM1 is also expressed on platelets ${ }^{31}$. However, it is unlikely that ORAI or STIM1 is changed in the Scott syndrome, since platelets from at least two patients show normal $\mathrm{Ca}^{2+}$ responses.

\section{Multiple contributions of glycoprotein $\mathrm{VI}$ to thrombus formation under flow}

Whereas the function of platelet GPVI in collagen-induced intracellular $\mathrm{Ca}^{2+}$ rises and PS exposure under flow has not been questioned, the precise role of GPVI in platelet adhesion and thrombus formation is less clear. Concerning adhesion, the relative contribution of the two collagen receptors, GPVI and $\alpha 2 \beta 1$, was the subject of considerable discussion in the past decades. According to the original two-site two-step adhesion model, high affinity interaction with collagen through $\alpha 2 \beta 1$ would slow down a platelet, and allow low affinity binding of $\mathrm{GPVI}^{32,33}$. However, studies with GPVI- or $\alpha 2 \beta 1$ deficient mice demonstrated that GPVI had a critical role in initial platelet adhesion and subsequent aggregation on collagen ${ }^{34}$. The same work showed that $\alpha 2 \beta 1$ was not 162 
required for these events. However, several later studies re-established that mouse $\alpha 2 \beta 1$ can facilitate the role of GPVI in platelet adhesion to collagen ${ }^{2,35}$.

Since for human platelets, the contribution of the two collagen receptors had remained unclear, we have studied this in chapter 4 . We observed that under high-shear flow conditions, GPVI does stimulate, but is not essential for primary platelet adhesion to collagen. Furthermore, we detected redundancy in the roles of $\alpha 2 \beta 1$ and GPIb-V-IX for platelet adhesion. Inhibiting GPlb or $\alpha 2 \beta 1$ on its own, but not GPVI, only partially reduced the number of collagen-adherent platelets. Combined inhibition of GPIb or $\alpha 2 \beta 1$ had a greater effect on platelet deposition, but still a significant number of aggregates were observed. That GPVI is in interplay with both other receptors is concluded from the observation that adhesion was completely abolished using a combined blockade of GPIb and GPVI or $\alpha 2 \beta 1$ and GPVI. This indicates that all three receptors play a role in adhesion, in contrast to procoagulant activity where only two receptors are involved. These results clearly deviate from those obtained using GPVI-deficient mice, which showed total abolition of platelet-collagen adhesion ${ }^{34}$. This issue of possible differences between human and mouse platelets was addressed by Auger et al. $^{36}$, who directly compared adhesion, activation and aggregation in either species. Two mechanisms of stable platelet adhesion and activation on collagen were shown to co-exist. In some platelets, adhesion involving $\alpha 2 \beta 1$ appears to be followed by GPVI-mediated increases in $\mathrm{Ca}^{2+}$ concentration, while in other platelets it precedes the $\mathrm{Ca}^{2+}$ response. This heterogeneity in responses is preserved in mouse and human platelets, and can explain apparent differences in the literature.

A number of studies have demonstrated that even minute amounts of GPVI signaling are sufficient to bring integrin $\alpha 2 \beta 1$ in a higher-affinity state, which permits this receptor to play a prominent role in adhesion ${ }^{37-39}$. Together with the present work, this has led to the recognition that platelet collagen responses are in a game of molecular ping-pong between different collagen receptors, in which GPVI is the first player to serve $^{40}$. With respect to platelet aggregation under flow, our data in chapter 4 and 5 are in full agreement with other studies with mouse and human blood that GPVI plays a key role in collagen-induced thrombus formation ${ }^{2,34,36,41}$. The GPVI signaling pathway underlying shear-dependent platelet aggregation involves the FcR $\gamma$-chain, Src-family kinases, Syk, LAT and PLC $\gamma 2$ (chapter 5). These are the same signaling components that have been shown to be involved in the GPVI-dependent aggregation response of suspensions of human and mouse platelets ${ }^{6,42,43}$. Our results with LAT, however, are remarkable, since with suspended LAT-deficient platelets aggregation was only reduced 
in the presence of low doses of collagen or collagen-related peptide, and became normalized at higher agonist doses ${ }^{44}$. This suggests that, the LAT pathway can be bypassed in collagen-induced suspension measurements, but not in (more physiological) flow measurements on collagen.

As shown by others, aggregate formation on a collagen surface is the result of several platelet responses, including activation of the fibrinogen-binding $\alpha$ llb $\beta 3$ integrin and release of the paracrine agents thromboxane $A_{2}$ and ADP (Figure 2) $38,45,46$. Particularly the release and the formation of thromboxane $A_{2}$ and the secretion of ADP are $\mathrm{Ca}^{2+}$-dependent responses, thus likely to be controlled by PLC $\gamma 2$ activation. The results presented in chapter 4 show that also human platelet aggregation under flow similarly as discussed for PS exposure - occurs through the concerted action of GPVI in cross-talk with $\alpha 2 \beta 1$. Accordingly, as indicated in Table 1, the same or similar sets of proteins and signaling mechanisms are implicated in aggregation and PS exposure during the thrombus-forming process.

In chapter 5, we further investigated the thrombus-forming process under conditions where the coagulation was triggered with tissue factor and the platelet aggregates accumulated massive amounts of fibrin. Although in the absence of GPVI activity, still trace amounts of fibrin could be detected (indicative of non-zero thrombin

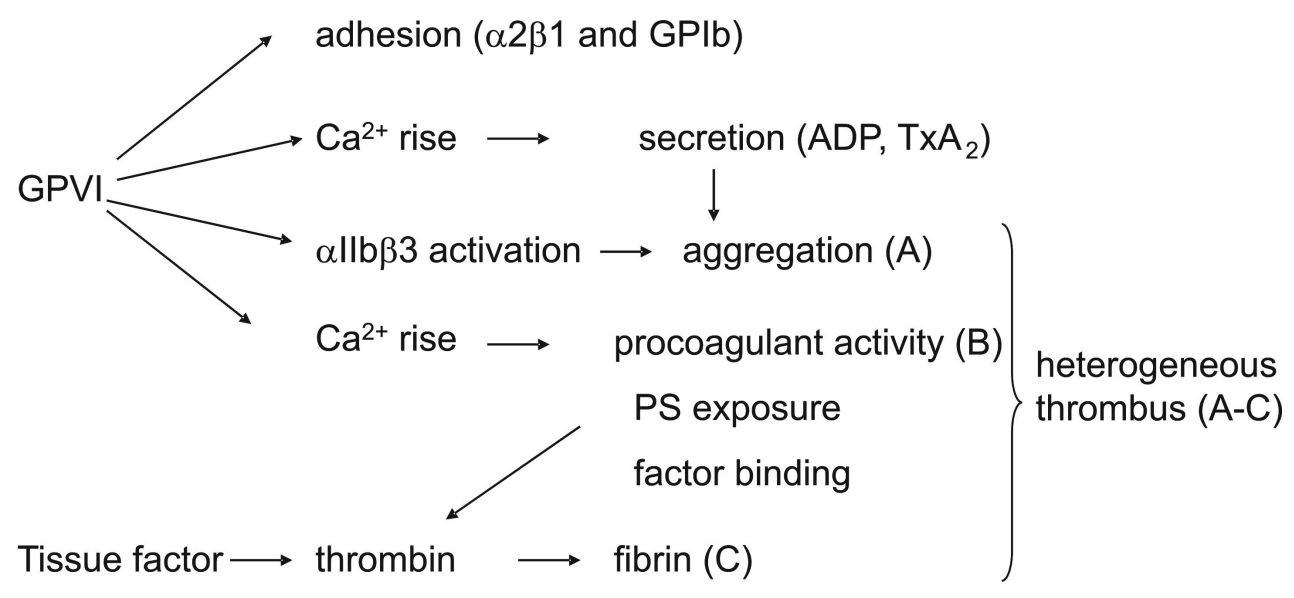

Figure 2 Overview of the roles of glycoprotein $\mathrm{VI}$ in thrombus formation. This thesis describes that platelet adhesion to collagen/vWF is mediated by GPVI in combination with $\alpha 2 \beta 1$ and GPIb. GPVI subsequently plays a key role in several platelet activation processes, including rise in intracellular $\mathrm{Ca}^{2+}$ concentration, secretion, integrin $\alpha$ llb $\beta 3$ activation and PS exposure. In the thrombus-forming process, this results in two populations of platelets either clustered into aggregates or with procoagulant activity. Both populations are embedded in a network of fibrin, formed as a result of the coagulation. 
Table 1 Contribution of platelet receptor and signaling proteins to thrombus formation on collagen

\begin{tabular}{lccccc}
\hline & Adhesion & $\mathrm{Ca}^{2+}$ signaling & PS exposure & Secretion & Aggregation \\
\hline $\mathrm{GPVI}$ & $+{ }^{*}$ & ++ & ++ & ++ & ++ \\
$\alpha 2 \beta 1$ & + & + & + & + & 0 \\
$\mathrm{FCR} \gamma$ & + & ++ & ++ & ++ & ++ \\
$\mathrm{LAT}$ & + & ++ & ++ & ++ & ++ \\
$\mathrm{PI} 3 \mathrm{~K} \alpha / \beta$ & 0 & + & + & + & + \\
$\mathrm{PI} 3 \mathrm{~K} \gamma$ & + & 0 & 0 & 0 & + \\
$\mathrm{PLC} \gamma 2$ & + & ++ & ++ & ++ & ++ \\
\hline
\end{tabular}

" 0 , no contribution; +, potentiating; ++, required.

formation), aggregated and PS-exposing platelets were hardly detected under this condition,

indicating that platelet activation by GPVI, most likely via PS exposure, is of key importance for full coagulant activity under the present flow conditions. Thus, GPVIinduced platelet activation can act as a driving force of the coagulation process in these flow chamber experiments. Interestingly, in the presence of GPVI activity, the number of PS-exposing platelets increased under conditions of coagulation (chapter 7). The most obvious explanation is that the processes of collagen-induced PS exposure and thrombin generation are interrelated and influence each other, likely through a positive feed forward loop, in a similar way as was previously suggested for platelet interaction with fibrin $^{47}$. Only few comparable studies with coagulation have been reported, but these particularly concerned ex vivo flow chamber experiments where effects of thromboxane $\mathrm{A}_{2}$ and ADP blockade were investigated instead of GPVI ${ }^{48}$.

In summary, we have shown that the GPVI receptor, acting via a relatively simple signaling pathway, is a principal mediator of aggregation and PS exposure, as well as platelet-dependent thrombin generation and fibrin formation (Figure 2).

\section{Composition and structure of a thrombus}

As shown in Table 1, a quite similar set of signaling proteins downstream of GPVI appears to be involved in two different platelet responses, i.e. PS exposure and aggregate formation. In chapters 5 and 6 , we show that these two responses are generated by quite different populations of platelets. In addition, during blood flow over collagen, we find that the aggregated and PS-exposing platelets tend to cluster in separate micro-domains within thrombi. The aggregated platelets bind fibrin(ogen), have 
activated $\alpha$ llb $\beta 3$ integrins and express P-selectin at their surface, which is a strong indicator of secretion. Separately, the thrombi contain patches of single PS-exposing platelets, which bind annexin A5 and have a bleb-forming morphology. The latter platelets are reduced in adhesion, do not tend to bind fibrin(ogen), but display increased binding for prothrombin, factor $\mathrm{Va}$ and factor $\mathrm{Xa}$, which properties are all compatible with a role in coagulation. While it is clear that the Gla-domain-containing factors Xa and prothrombin bind to PS-exposing membranes, we have not further examined the coagulation factor binding sites on platelets.

Previously, others have characterised a population of so-called coated platelets that express serotonin binding sites and attract factor $\mathrm{Va}$, fibrinogen, vWF, fibronectin and thrombospondin ${ }^{49}$. However, in our studies with labelled fibrinogen and coagulation factors, the platelets that express serotonin binding sites could not be distinguished as a separate population of cells, but partially overlapped with the two other platelet populations. Given these results it can be questioned whether the coated platelets described by others in fact represent a unique platelet population.

An important question is how one and the same signaling pathway, starting from GPVI and leading to PLC $\gamma 2$ activation, can result in so different platelet responses within a single thrombus. In chapter 7 , a first clue observation that can explain the platelet heterogeneity came from flow cytometry experiments. These showed that all GPVI-activated platelets at first express activated forms of integrin $\alpha$ llb $\beta 3$, while at a later stage secondary inactivation of the integrins on PS-exposing platelets occurs. This suggests that initially all platelets are well equipped to incorporate into aggregates, but that later only the PS negative platelets have retained this property. This is in agreement with the observation that, under flow conditions, platelets in aggregates fail to expose PS. It can be speculated that platelets in aggregates are protected from PS exposure, but we do not have evidence to support this hypothesis. Earlier data indicate that platelets with a prolonged and high $\mathrm{Ca}^{2+}$ signal tend to expose PS and become procoagulant $^{50,51}$. In combination with the present findings, this suggests that a prolonged $\mathrm{Ca}^{2+}$ increase not only causes phospholipid scrambling, but also leads to $\alpha \mathrm{llb} \beta 3$ inactivation (Figure 3).

A second novel observation is that blocking of protein tyrosine phosphatases enhances the secondary integrin inactivation in GPVI-stimulated platelets. Since tyrosine kinases can act $\mathrm{Ca}^{2+}$-dependently, it is likely that prolonged elevation in $\mathrm{Ca}^{2+}$ leads to both PS exposure and tyrosine kinase-dependent integrin inactivation. Measurement of $\mathrm{Ca}^{2+}$ fluctuations in platelets under flow conditions indeed showed considerable heterogeneity between platelets. Considering that the height of the $\mathrm{Ca}^{2+}$ response is a 166 
critical determinant of PS exposure and is coupled to this integrin inactivation, there are several possible explanations for the response heterogeneity.

It can be caused by variation in the expression levels of one or more platelet receptors or signaling proteins, e.g. by allelic differences in the GPVI gene ${ }^{52}$. Also the platelet's age may play a role, since older platelets may loose or gain surface expression of functional glycoprotein receptors. For instance, GPIb-V-IX and GPVI have been shown to be sensitive for clustering and protease-mediated cleavage during storage ${ }^{53-55}$. Following this reasoning, GPIb clustering may make older platelets more susceptible for tethering on (collagen-bound) VWF or for aggregation mediated via GPIb-VWF interaction. Another possibility is that micro-environmental diversities upon platelet adhesion cause later response heterogeneity. All together, this leads to the idea that restricted GPVI activity and/or signaling leads to a proaggregatory response, while high stimulation of the GPVI pathway enhances procoagulant activity. This hypothesis is supported by a recent study, in which protein kinase $\mathrm{C}$ was identified as a signaling protein to enhance platelet aggregation but suppresses $\mathrm{Ca}^{2+}$ and procoagulant responses during thrombus formation on collagen ${ }^{56}$.

Some authors have proposed that extracellular transglutaminases like factor XIIla contribute to the formation of coagulation-active platelets by cross-linking surfacemembrane proteins to secretion factors, e.g. via serotonin conjugation to form coated platelets $^{51,57}$. However, we were not able to confirm this result, since in our hands inhibition of transglutaminases had no effect on PS exposure by GPVI-stimulated platelets. Our findings are, however, in line with a recent report in which it was shown

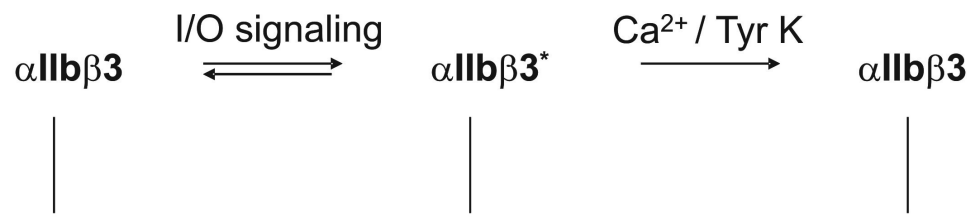

single, discoid platelets aggregated platelets single, blebbing platelets

$\begin{array}{cc}\text { inaccessible to } & \text { accessible to } \\ \text { coagulation factors } & \text { coagulation factors }\end{array}$

Figure 3 New model of transient integrin $\alpha$ llb $\beta 3$ activation. Inside-out signaling is known to lead to $\alpha$ llb $\beta 3$ activation, exposing fibrinogen-binding epitopes on the integrin. We provided evidence that this activated conformation is a transient state, as prolonged $\mathrm{Ca}^{2+}$ elevation and tyrosine phosphorylation events lead to secondary inactivation of the integrins on PS-exposing platelets. Typically, these procoagulant platelets are single, non-adherent with a blebbing morphology. For further explanations, see text. 
that the binding of secretory proteins and annexin A5 to platelets on collagen requires GPVI/FcR $\gamma$-chain activity, but not factor XIIIa ${ }^{58}$. It was also proposed that intracellular or extracellular calpain activity contributes to the development of procoagulant platelets 51,59. In agreement with earlier results, however, we find no major role for calpain in the regulation of platelet procoagulant activity, although calpain is involved in gaining the bleb-shaped morphology of the cells ${ }^{50}$.

A novel finding in chapter 7 is that, while heterogeneity is maintained during perfusion of blood under conditions of thrombin generation and coagulation, the frequency of procoagulant, PS-exposing platelets becomes higher in this case. Furthermore, it appears that the PS-exposing platelets bind all components of the prothrombinase complex. Taken together, these results indicate that collagen provides an adhesive substrate, at which the processes of platelet aggregation and coagulation are integrated but also separated over different micro-domains.

\section{Roles of collagen and glycoprotein $\mathrm{VI}$ in thrombus formation in vivo}

In the studies presented in chapters 5 and 7 , an established $\mathrm{FeCl}_{3}$ microvascular thrombosis model was used to study the importance of collagen and GPVI in the thrombotic process in vivo. Upon application to adjacent arteries and veins, the free radical-generating compound $\mathrm{FeCl}_{3}$ caused endothelial denudation and subsequent exposure of the collagen-containing extracellular matrix ${ }^{60}$. We used several approaches to show that arterial thrombus formation relies on collagen-GPVI interaction and subsequent signaling. Thus, in mesenteric arteries from mice lacking the FcR $\gamma$-chain, no thrombi were formed after $\mathrm{FeCl}_{3}$ application. Also, in mice where GPVI on the platelet surface was down-regulated by long-term injection with anti-GPVI JAQ1 mAb, thrombus formation in arteries was delayed and reduced. In the damaged arteries of wild-type control mice, we were able to visualize externalized PS on platelets that were trapped in thrombi, using fluorescently labeled annexin A5. However, in vessels from mice preinjected with JAQ1 mAb, only small spots of labeled fibrin were present and labeled annexin A5 was not detectable at all. Accordingly, both GPVI-induced responses, aggregation and PS exposure, observed in vitro, were also present in thrombi formed in vivo. That murine GPVI has a function in arterial thrombus formation in vivo was also proven in other mouse studies using the same $\mathrm{FeCl}_{3}$ method ${ }^{61,62}$. Yet, with mild $\mathrm{FeCl}_{3}$ induced injury, thrombus formation in FcR $\gamma$-chain deficient mice appeared to be normal, probably due to minimal exposure of collagen ${ }^{62}$. Confusing results were obtained when thrombus formation was induced by superficial or severe laser injury. Here, GPVI/PLC $\gamma 2$ 
effects were only detected after the superficial laser injury ${ }^{63,64}$. Furthermore, also in large arteries, ligation models demonstrate a role for GPVI in thrombus formation ${ }^{61}$.

We used the method of $\mathrm{FeCl}_{3}$-induced injury to study the role of procoagulant platelets and thrombin in arterial thrombosis in vivo (chapter 7). Infusion of annexin A5 completely inhibited thrombus formation in the mesenteric arteries. Moderate thrombin inhibition with melagatran or platelet inhibition with prostaglandin $\mathrm{E}_{1}$ completely blocked arterial thrombus formation. Thus, besides GPVI, procoagulant platelets mediating thrombin generation and coagulation play a key role in this microvascular thrombosis model. In agreement with the present findings, others also describe that thrombin ${ }^{60}$ and platelet thrombin receptors ${ }^{65,66}$ contribute to $\mathrm{FeCl}_{3}$-induced thrombus formation in small arteries. In this context, it should be noted that a drawback of many in vivo thrombosis models is the lack of information on the precise type of vascular damage and the extent of collagen exposure.

Some of the experiments in this thesis are focussed on perfusion of blood at intermediate shear over a glass surface coated with fibrillar collagen. It is important to know whether this flow-chamber system provides a physiological model for the events of thrombus formation in vivo. Interestingly, comparison of the in vitro flow studies with the in vivo mice data shows great similarity between the two methods used (chapters 5-7). Both in vitro and in vivo we detect a key role of GPVI in the thrombus formation and procoagulant activity, and similarly, in the heterogeneous composition of the formed thrombi. Therefore, the in vitro flow model seems to mimic the conditions of in vivo thrombus formation, although obviously no vessel is present. There are, however, clearly limitations of the flow-chamber model, one being that type I collagen is used in the present work, while other types of collagen (type IV) are also abundantly present in the vascular extracellular matrix, and can support platelet activation. In addition, the contribution of other matrix proteins, e.g. laminin, to platelet adhesion and thrombus formation can not be ruled out ${ }^{67}$. It is therefore of interest to extend the present model to the study of additional collagen types and other matrix proteins, either in isolation or in combination.

\section{Role of thrombin in arterial and venous thrombosis}

An important question is to which extent platelets and coagulation contribute to arterial and venous thrombosis. Using the $\mathrm{FeCl}_{3}$ method, a number of characteristic differences between thrombus formation in mesenteric arteries and veins are described in chapter 6 . In this model, platelet inhibition by prostaglandin $E_{1}$ or moderate thrombin 
inhibition by melagatran was insufficient to affect venous thrombus formation, although arterial thrombosis was greatly inhibited. The combined action of both agents or a higher dose of melagatran was needed to reduce the thrombotic process in the veins. An attractive explanation for this difference is that thrombin generation is locally higher in veins than in arteries, for instance due to a slower flow-mediated dilution of thrombin and other coagulation factors ${ }^{68}$. Alternatively, since endothelial cells of arteries and veins can have different antithrombotic properties ${ }^{69}$, increased suppression of the coagulation process in the mesenteric arteries may explain their relatively high responsiveness to thrombin inhibition. More speculative is the hypothesis that $\mathrm{FeCl}_{3}$-induced damage of the mesenteric veins results in the exposure of more coagulation-stimulating vascular material, such as tissue factor. Indeed, the expression of tissue factor does not appear to be uniform throughout the vascular tree ${ }^{70}$. An interesting parallel is seen in a model of laser-induced arterial thrombus formation, where suppressed platelet activation (using FcR $\gamma$-chain deficient mice) only affected thrombus formation, when thrombin was simultaneously inhibited ${ }^{63}$. These data suggests that, also in arterial thrombosis, high thrombin formation can overrule the contribution of specific platelet-activating pathways.

\section{In prospective}

The studies in this thesis shed new light on the importance of coagulation and platelet activation for thrombus formation under arterial and venous flow conditions. A relevant finding is the observation that absence or inhibition of the collagen receptor, GPVI, can significantly suppress thrombus formation and platelet procoagulant activity both in small and large arteries. This makes GPVI a new interesting target for future antithrombotic treatment. Another relevant finding is the relatively high accumulation of thrombin in vivo in veins, and in vitro at venous shear rates. It is thus important to realize that the suggested antithrombotic effect of GPVI can be bypassed by high thrombin generation and coagulation under conditions of low shear. This also explains why patients lacking GPVI suffer from no more than a mild bleeding diathesis. Similarly, in mice, GPVI deficiency is not accompanied by prolonged bleeding times. Together, this suggests that anti-GPVI treatment may be most effective in case of arterial thrombosis (low thrombin), rather than in case of venous thrombosis (high thrombin). In addition, it provides more information on the structural organization of such thrombi. Currently, several clinical trials are started to validate the antithrombotic effect of GPVI. 


\section{References}

1. Kuijpers MJ, Schulte V, Oury C, Lindhout T, Broers J, Hoylaerts MF, Nieswandt B, Heemskerk JW. Facilitating roles of murine platelet glycoprotein $\mathrm{lb}$ and $\alpha \mathrm{llb} \beta 3$ in phosphatidylserine exposure during vWF-collagen-induced thrombus formation. J Physiol. 2004;558:403-415.

2. Kuijpers MJ, Schulte V, Bergmeier W, Lindhout T, Brakebusch C, Offermanns S, Fassler R, Heemskerk JW, Nieswandt B. Complementary roles of glycoprotein VI and $\alpha 2 \beta 1$ integrin in collagen-induced thrombus formation in flowing whole blood ex vivo. FASEB J. 2003;17:685687.

3. Lecut C, Feeney LA, Kingsbury G, Hopkins J, Lanza F, Gachet C, Villeval JL, Jandrot-Perrus M. Human platelet glycoprotein VI function is antagonized by monoclonal antibody-derived Fab fragments. J Thromb Haemost. 2003;1:2653-2662.

4. Munnix IC, Strehl A, Kuijpers MJ, Auger JM, van der Meijden PE, van Zandvoort MA, oude Egbrink MG, Nieswandt B, Heemskerk JW. The glycoprotein VI-phospholipase C $\gamma 2$ signaling pathway controls thrombus formation induced by collagen and tissue factor in vitro and in vivo. Arterioscler Thromb Vasc Biol. 2005;25:2673-2678.

5. Smeets EF, Comfurius P, Bevers EM, Zwaal RFA. Calcium-induced transbilayer scrambling of fluorescent phospholipid analogs in platelets and erythrocytes. Biochim Biophys Acta. 1994;1195:281-286.

6. Nieswandt B, Watson SP. Platelet-collagen interaction: is GPVI the central receptor? Blood. 2003;102:449-461.

7. Watson SP, Auger JM, McCarty OJ, Pearce AC. GPVI and integrin $\alpha$ llb $\beta 3$ signaling in platelets. J Thromb Haemost. 2005;3:1752-1762.

8. Heemskerk JW, Vuist WM, Feijge MA, Reutelingsperger CP, Lindhout T. Collagen but not fibrinogen surfaces induce bleb formation, exposure of phosphatidylserine, and procoagulant activity of adherent platelets: evidence for regulation by protein tyrosine kinase-dependent $\mathrm{Ca}^{2+}$ responses. Blood. 1997;90:2615-2625.

9. Mocsai $A$, Zhou M, Meng F, Tybulewicz VL, Lowell CA. Syk is required for integrin signaling in neutrophils. Immunity. 2002;16:547-558.

10. Hughan SC, Hughes CE, McCarty OJ, Schweighoffer E, Soultanova I, Ware J, Tybulewicz VL, Watson SP. GPVI Potentiation of Platelet Activation by Thrombin and Adhesion Molecules Independent of Src Kinases and Syk. Arterioscler Thromb Vasc Biol. 2006

11. Schlessinger J. Cell signaling by receptor tyrosine kinases. Cell. 2000;103:211-225.

12. Jackson SP, Schoenwaelder SM, Goncalves I, Nesbitt WS, Yap CL, Wright CE, Kenche V, Anderson KE, Dopheide SM, Yuan Y, Sturgeon SA, Prabaharan H, Thompson PE, Smith GD, Shepherd PR, Daniele N, Kulkarni S, Abbott B, Saylik D, Jones C, Lu L, Giuliano S, Hughan SC, Angus JA, Robertson AD, Salem HH. PI 3-kinase p110ß: a new target for antithrombotic therapy. Nat Med. 2005;11:507-514.

13. Gibbins JM, Briddon S, Shutes A, van Vugt MJ, van de Winkel JG, Saito T, Watson SP. The p85 subunit of phosphatidylinositol 3-kinase associates with the Fc receptor $\gamma$-chain and linker for activitor of T cells (LAT) in platelets stimulated by collagen and convulxin. J Biol Chem. 1998;273:34437-34443.

14. Zhang J, Zhang J, Shattil SJ, Cunningham MC, Rittenhouse SE. Phosphoinositide 3-kinase gamma and $\mathrm{p} 85 /$ phosphoinositide 3-kinase in platelets. Relative activation by thrombin receptor or $\beta$-phorbol myristate acetate and roles in promoting the ligand-binding function of $\alpha$ llb $\beta 3$ integrin. J Biol Chem. 1996;271:6265-6272.

15. Tang $X$, Downes CP. Purification and characterization of $G \beta \gamma$-responsive phosphoinositide 3kinases from pig platelet cytosol. J Biol Chem. 1997;272:14193-14199.

16. Watanabe N, Nakajima H, Suzuki H, Oda A, Matsubara Y, Moroi M, Terauchi Y, Kadowaki T, Suzuki H, Koyasu S, Ikeda Y, Handa M. Functional phenotype of phosphoinositide 3-kinase p85 $\alpha$-null platelets characterized by an impaired response to GP VI stimulation. Blood. 2003;102:541-548. 
17. Hirsch E, Bosco O, Tropel P, Laffargue M, Calvez R, Altruda F, Wymann M, Montrucchio G. Resistance to thromboembolism in PI3K $\gamma$-deficient mice. Faseb J. 2001;15:2019-2021.

18. Zhang J, Vanhaesebroeck B, Rittenhouse SE. Human platelets contain p1108 phosphoinositide 3-kinase. Biochem Biophys Res Commun. 2002;296:178-181.

19. Suzuki H, Terauchi Y, Fujiwara M, Aizawa S, Yazaki Y, Kadowaki T, Koyasu S. Xid-like immunodeficiency in mice with disruption of the p85 $\alpha$ subunit of phosphoinositide 3-kinase. Science. 1999;283:390-392.

20. Terauchi $\mathrm{Y}$, Tsuji $\mathrm{Y}$, Satoh S, Minoura H, Murakami K, Okuno A, Inukai K, Asano T, Kaburagi Y, Ueki K, Nakajima H, Hanafusa T, Matsuzawa Y, Sekihara H, Yin Y, Barrett JC, Oda H, Ishikawa T, Akanuma Y, Komuro I, Suzuki M, Yamamura K, Kodama T, Suzuki H, Yamamura K, Kodama T, Suzuki H, Koyasu S, Aizawa S, Tobe K, Fukui Y, Yazaki Y, Kadowaki T. Increased insulin sensitivity and hypoglycaemia in mice lacking the p85 $\alpha$ subunit of phosphoinositide 3-kinase. Nat Genet. 1999;21:230-235.

21. Senis YA, Atkinson BT, Pearce AC, Wonerow P, Auger JM, Okkenhaug K, Pearce W, Vigorito E, Vanhaesebroeck B, Turner M, Watson SP. Role of the p110 $\mathrm{PI}$ 3-kinase in integrin and ITAM receptor signaling in platelets. Platelets. 2005;16:191-202.

22. Cosemans JM, Munnix IC, Wetzker R, Heller R, Jackson SP, Heemskerk JW. Continuous signaling via PI3K isoforms $\beta$ and $\gamma$ is required for platelet ADP receptor function in dynamic thrombus stabilization. Blood. 2006;108:3045-3052.

23. Pasquet JM, Quek L, Stevens C, Bobe R, Huber M, Duronio V, Krystal G, Watson SP. Phosphatidylinositol 3,4,5-trisphosphate regulates $\mathrm{Ca}^{2+}$ entry via btk in platelets and megakaryocytes without increasing phospholipase C activity. EMBO J. 2000;19:2793-2802.

24. Martin S, Laude-Lemaire I, Kerbiriou-Nabias D, Freyssinet JM, Martinez MC. Relation between phosphatidylserine exposure and store-operated $\mathrm{Ca}^{2+}$ entry in stimulated cells. Biochem Biophys Res Commun. 2000;279:639-645.

25. Martinez MC, Martin S, Toti F, Fressinaud E, Dachary-Prigent J, Meyer D, Freyssinet JM. Significance of capacitative $\mathrm{Ca}^{2+}$ entry in the regulation of phosphatidylserine expression at the surface of stimulated cells. Biochemistry. 1999;38:10092-10098.

26. Zwaal RF, Schroit AJ. Pathophysiologic implications of membrane phospholipid asymmetry in blood cells. Blood. 1997;89:1121-1132.

27. Zwaal RF, Comfurius P, Bevers EM. Surface exposure of phosphatidylserine in pathological cells. Cell Mol Life Sci. 2005;62:971-988.

28. Wolfs JL, Wielders SJ, Comfurius P, Lindhout T, Giddings JC, Zwaal RF, Bevers EM. Reversible inhibition of the platelet procoagulant response through manipulation of the Gardos channel. Blood. 2006;108:2223-2228.

29. Prakriya M, Feske S, Gwack Y, Srikanth S, Rao A, Hogan PG. Orai1 is an essential pore subunit of the CRAC channel. Nature. 2006;443:230-233.

30. Stathopulos PB, Li GY, Plevin MJ, Ames JB, Ikura M. Stored $\mathrm{Ca}^{2+}$ depletion-induced oligomerization of stromal interaction molecule 1 (STIM1) via the EF-SAM region: An initiation mechanism for capacitive $\mathrm{Ca}^{2+}$ entry. J Biol Chem. 2006;281:35855-35862.

31. Lopez JJ, Salido GM, Pariente JA, Rosado JA. Interaction of STIM1 with endogenously expressed human canonical TRP1 upon depletion of intracellular $\mathrm{Ca}^{2+}$ stores. J Biol Chem. 2006;281:28254-28264.

32. Morton LF, Peachey AR, Barnes MJ. Platelet-reactive sites in collagens type I and type III. Evidence for separate adhesion and aggregatory sites. Biochem J. 1989;258:157-163.

33. Santoro SA, Walsh JJ, Staatz WD, Baranski KJ. Distinct determinants on collagen support $\alpha 2$ $\beta 1$ integrin-mediated platelet adhesion and platelet activation. Cell Regul. 1991;2:905-913.

34. Nieswandt B, Brakebusch C, Bergmeier W, Schulte V, Bouvard D, Mokhtari-Nejad R, Lindhout T, Heemskerk JW, Zirngibl H, Fassler R. Glycoprotein VI but not $\alpha 2 \beta 1$ integrin is essential for platelet interaction with collagen. EMBO J. 2001;20:2120-2130. 
35. Chen J, Diacovo TG, Grenache DG, Santoro SA, Zutter MM. The $\alpha 2$ integrin subunit-deficient mouse: a multifaceted phenotype including defects of branching morphogenesis and hemostasis. Am J Pathol. 2002;161:337-344.

36. Auger JM, Kuijpers MJ, Senis YA, Watson SP, Heemskerk JW. Adhesion of human and mouse platelets to collagen under shear: a unifying model. FASEB J. 2005;19:825-827.

37. Jung SM, Moroi M. Signal-transducing mechanisms involved in activation of the platelet collagen receptor integrin $\alpha 2 \beta 1$. J Biol Chem. 2000;275:8016-8026.

38. Lecut C, Schoolmeester A, Kuijpers MJ, Broers JL, van Zandvoort MA, Vanhoorelbeke K, Deckmyn H, Jandrot-Perrus M, Heemskerk JW. Principal role of glycoprotein VI in $\alpha 2 \beta 1$ and $\alpha$ llb $\beta 3$ activation during collagen-induced thrombus formation. Arterioscler Thromb Vasc Biol. 2004;24:1727-1733.

39. Van de Walle GR, Schoolmeester A, Iserbyt BF, Cosemans JM, Heemskerk JW, Hoylaerts MF, Nurden A, Vanhoorelbeke K, Deckmyn H. Activation of $\alpha$ llb $\beta 3$ is a sufficient but also an imperative prerequisite for activation of $\alpha 2 \beta 1$ on platelets. Blood. 2007;109:595-602.

40. Kahn ML. Platelet collagen receptors play molecular ping-pong. Blood. 2004;103:1180-1181.

41. Kato K, Kanaji T, Russell S, Kunicki TJ, Furihata K, Kanaji S, Marchese P, Reininger A, Ruggeri ZM, Ware J. The contribution of glycoprotein VI to stable platelet adhesion and thrombus formation illustrated by targeted gene deletion. Blood. 2003;102:1701-1707.

42. Ezumi Y, Shindoh K, Tsuji M, Takayama H. Physical and functional association of the Src family kinases Fyn and Lyn with the collagen receptor glycoprotein VI-Fc receptor $\gamma$-chain complex on human platelets. J Exp Med. 1998;188:267-276.

43. Watson SP. Collagen receptor signaling in platelets and megakaryocytes. Thromb Haemost. 1999;82:365-376.

44. Cho MJ, Pestina TI, Steward SA, Jackson CW, Kent Gartner T. The roles of LAT in platelet signaling induced by collagen, $\mathrm{TxA}_{2}$, or ADP. Biochem Biophys Res Commun. 2002;292:916921.

45. Ruggeri ZM. Platelets in atherothrombosis. Nat Med. 2002;8:1227-1234.

46. Remijn JA, Wu YP, Heninga EH, IJsseldijk MJW, van Willigen G, de Groot PG, Sixma JJ, Nurden AT, Nurden P. Role of ADP receptor $\mathrm{P}_{2} \mathrm{Y}_{12}$ in platelet adhesion and thrombus formation in flowing blood. Arterioscler Thromb Vasc Biol. 2002;22:686-691.

47. Béguin $\mathrm{S}$, Kumar R. Thrombin, fibrin and platelets, a resonance loop in which von Willebrand factor is a necessary link. Thromb Haemost. 1997;78:590-594.

48. Sakariassen KS, Hanson SR, Cadroy Y. Methods and models to evaluate shear-dependent and surface reactivity-dependent antithrombotic efficacy. Thromb Res. 2001;104:149-174.

49. Dale GL. Coated-platelets: an emerging component of the procoagulant response. J Thromb Haemost. 2005;3:2185-2192.

50. Siljander P, Farndale RW, Feijge MA, Comfurius P, Kos S, Bevers EM, Heemskerk JW. Platelet adhesion enhances the glycoprotein VI-dependent procoagulant response: Involvement of p38 MAP kinase and calpain. Arterioscler Thromb Vasc Biol. 2001;21:618-627.

51. Kulkarni S, Jackson SP. Platelet factor XIII and calpain negatively regulate integrin $\alpha$ llb $\beta 3$ adhesive function and thrombus growth. J Biol Chem. 2004;279:30697-30706.

52. Joutsi-Korhonen L, Smethurst PA, Rankin A, Gray E, M IJ, Onley CM, Watkins NA, Williamson LM, Goodall AH, de Groot PG, Farndale RW, Ouwehand WH. The low-frequency allele of the platelet collagen signaling receptor glycoprotein $\mathrm{VI}$ is associated with reduced functional responses and expression. Blood. 2003;101:4372-4379.

53. Hoffmeister KM, Felbinger TW, Falet $\mathrm{H}$, Denis CV, Bergmeier W, Mayadas TN, von Andrian UH, Wagner DD, Stossel TP, Hartwig JH. The clearance mechanism of chilled blood platelets. Cell. 2003;112:87-97.

54. Bergmeier W, Rabie T, Strehl A, Piffath CL, Prostredna M, Wagner DD, Nieswandt B. GPVI down-regulation in murine platelets through metalloproteinase-dependent shedding. Thromb Haemost. 2004;91:951-958. 
55. Bergmeier W, Burger PC, Piffath CL, Hoffmeister KM, Hartwig JH, Nieswandt B, Wagner DD. Metalloproteinase inhibitors improve the recovery and hemostatic function of in vitro-aged or injured mouse platelets. Blood. 2003;102:4229-4235.

56. Strehl A, Munnix IC, Kuijpers MJ, van der Meiden P, Cosemans JM, Feijge MA, Nieswandt B, Heemsker JW. Dual role of platelet protein kinase C in thrombus formation: Stimulation of proaggregatory and suppression of procoagulant activity in platelets. J Biol Chem. 2007;282:7046-7055.

57. Dale GL, Friese P, Batar P, Hamilton SF, Reed GL, Jackson KW, Clemetson KJ, Alberio L. Stimulated platelets use serotonin to enhance their retention of procoagulant proteins on the cell surface. Nature. 2002;415:175-179.

58. Jobe SM, Leo L, Eastvold JS, Dickneite G, Ratliff TL, Lentz SR, Di Paola J. Role of FcRy and factor XIIIA in coated platelet formation. Blood. 2005;106:4146-4151.

59. Bachelot-Loza C, Badol P, Brohard-Bohn B, Fraiz N, Cano E, Rendu F. Differential regulation of platelet aggregation and aminophospholipid exposure by calpain. $\mathrm{Br} \mathrm{J}$ Haematol. 2006;133:419-426.

60. Ni H, Ramakrishnan V, Ruggeri ZM, Papalia JM, Phillips DR, Wagner DD. Increased thrombogenesis and embolus formation in mice lacking glycoprotein V. Blood. 2001;98:368-373.

61. Massberg S, Gawaz M, Gruner S, Schulte V, Konrad I, ZohInhofer D, Heinzmann U, Nieswandt B. A crucial role of glycoprotein $\mathrm{VI}$ for platelet recruitment to the injured arterial wall in vivo. J Exp Med. 2003;197:41-49.

62. Dubois C, Panicot-Dubois L, Merrill-Skoloff G, Furie B, Furie BC. Glycoprotein VI-dependent and -independent pathways of thrombus formation in vivo. Blood. 2006;107:3902-3906.

63. Mangin P, Yap CL, Nonne C, Sturgeon SA, Goncalves I, Yuan Y, Schoenwaelder SM, Wright $\mathrm{CE}$, Lanza F, Jackson SP. Thrombin overcomes the thrombosis defect associated with platelet GPVI/FcR $\gamma$ deficiency. Blood. 2006;107:4346-4353.

64. Nonne C, Lenain N, Hechler B, Mangin P, Cazenave JP, Gachet C, Lanza F. Importance of platelet phospholipase $\mathrm{C} \gamma 2$ signaling in arterial thrombosis as a function of lesion severity. Arterioscler Thromb Vasc Biol. 2005;25:1293-1298.

65. Weiss EJ, Hamilton JR, Lease KE, Coughlin SR. Protection against thrombosis in mice lacking PAR3. Blood. 2002;100:3240-3244.

66. Sambrano GR, Weiss EJ, Zheng YW, Huang W, Coughlin SR. Role of thrombin signaling in platelets in haemostasis and thrombosis. Nature. 2001;413:74-78.

67. Badimon L, Chesebro JH, Badimon JJ. Thrombus formation on ruptured atherosclerotic plaques and rethrombosis on evolving thrombi. Circulation. 1992;86:III74-85.

68. Kuijpers MJ. Platelet receptors and procoagulant activity in thrombus formation. Thesis. 2006

69. Broeders MA, Tangelder GJ, Slaaf DW, Reneman RS, Egbrink MG. Endogenous nitric oxide and prostaglandins synergistically counteract thromboembolism in arterioles but not in venules. Arterioscler Thromb Vasc Biol. 2001;21:163-169.

70. Mackman N. Role of tissue factor in hemostasis, thrombosis, and vascular development. Arterioscler Thromb Vasc Biol. 2004;24:1015-1022. 
Summary 
Intravascular thrombosis is classified as venous thrombosis (e.g., in deep veins) or arterial thrombosis (as in myocardial infarction and ischemic stroke). Irrespective of other factors (vessel wall, circulation and blood cell composition), venous thrombosis is commonly associated with high coagulation activity, which can cause undesired fibrin clot deposition. On the other hand, arterial thrombosis is often linked to high platelet activation, which leads to the formation of platelet-rich thrombi. Although nowadays there are good examples of favorable combination therapy with anticoagulant and antiplatelet drugs, anticoagulants are still preferred in reducing venous thromboembolism while antiplatelet agents are mostly used in the prevention of arterial thrombosis. Irrespective of this, laboratory investigations indicate that the processes of platelet activation and coagulation are strongly mutually dependent. The crucial coagulation product, thrombin, is one of the most potent platelet agonists known. Conversely, activated platelets are essential in providing the procoagulant surface at which thrombin generation occurs. This is in apparent contrast with the supposed differential roles of thrombin and activated platelets in venous and arterial thrombosis, respectively. Hence, the main goal of this thesis is to investigate the diversity in interaction mechanisms between platelet activation and coagulation in different situations and on different levels of complexity.

Platelets can be activated by complex cascades of signaling pathways. Current knowledge of a number of these pathways is described in chapter 1. Emphasised is how the ADP receptor, $\mathrm{P}_{2} \mathrm{Y}_{12}$, the thrombin receptors, PAR1 and PAR4, and the collagen receptor, glycoprotein (GP)VI, activate the phosphoinositide 3-kinase (PI3K) pathway by producing phosphoinositide 3,4,5-trisphosphate. Particularly, PI3K that is activated downstream of GPVI plays a role in recruiting phospholipase C- $\gamma 2$ (PLC $\gamma 2$ ) to the plasma membrane. Activation of PLC $\gamma 2$ leads to $\mathrm{Ca}^{2+}$ elevation by mobilisation of $\mathrm{Ca}^{2+}$ from internal stores, and subsequent secretion and exposure of phosphatidylserine (PS) at the platelet surface. Earlier literature is cited that PS-exposing platelets are active in thrombin generation and coagulation, by providing a surface at which coagulation factors assemble. Separately, $\mathrm{P}_{2} \mathrm{Y}_{12}$ and PAR receptor stimulation activates the so-called Rap1b, PI3K and Akt pathway, which leads to integrin $\alpha$ llb $\beta 3$ activation and hence platelet aggregation.

The rare Scott syndrome is a bleeding disorder, characterized by impaired surface exposure of procoagulant PS on activated platelets and other blood cells. Since store-mediated $\mathrm{Ca}^{2+}$ entry is essential for the procoagulant response of platelets, we investigated in chapter 2 whether the $\mathrm{Ca}^{2+}$ entry process is impaired in blood cells from Scott patients. Measurements of $\mathrm{Ca}^{2+}$ fluxes and PS exposure were performed in isolated platelets and in immortalized B-cell lymphoblasts from two different patients. The 
responses of platelets and B-cells from the Scott patients appeared to be unaltered in comparison to cells from control subjects. On the other hand, the extent of PS exposure in response to GPVI stimulation was strongly reduced in patient platelets. These results thus indicate that impaired phospholipid scrambling in Scott cells can not be ascribed to alterations in $\mathrm{Ca}^{2+}$ signaling, e.g. of diminished $\mathrm{Ca}^{2+}$ entry.

Inositol phospholipids, especially those produced by PI3K, play key roles in $\mathrm{Ca}^{2+}$ signaling in platelets. Chapter 3 describes a study on the role of various platelet $\mathrm{PI} 3 \mathrm{~K}$ isoforms in the regulation of $\mathrm{Ca}^{2+}$ signaling, following platelet activation by collagen or thrombin. Mice lacking the $\mathrm{p} 85 \alpha$ regulatory subunit (class $1 \mathrm{~A} \mathrm{PI} 3 \mathrm{~K}$ ) or the $\mathrm{p} 110 \gamma$ catalytic subunit (class $1 \mathrm{~B} \mathrm{PI3K} \gamma$ ) were used, as well as several newly developed inhibitors interacting with the catalytic subunits of the various PI3Ks present in platelets. The results indicate that both the $p 85 \alpha$ regulatory subunit and the catalytic $p 110 \beta$ activity contribute significantly to $\mathrm{Ca}^{2+}$ signaling and subsequent PS exposure elicited by collagen receptor activation. This contribution occurs via the classical $\mathrm{Ca}^{2+}$ pathway, i.e. by enhancing the PLC-dependent $\mathrm{Ca}^{2+}$ mobilisation and subsequent store-mediated $\mathrm{Ca}^{2+}$ entry. The class $1 \mathrm{~A} \mathrm{PI} 3 \mathrm{~K} \delta$ and the class $1 \mathrm{~B} \mathrm{PI} 3 \mathrm{~K} \gamma$ isoforms do not seem to have a prominent role in this process.

In the in vitro flow studies reported in chapter 4 , the interacting roles of the platelet adhesive receptors for von Willebrand factor (VWF), i.e. GPIb-V-IX and integrin $\alpha \operatorname{llb} \beta 3$, and for collagen, i.e. GPVI and integrin $\alpha 2 \beta 1$, were examined. Studies were performed to measure thrombus formation and procoagulant activity during high-shear perfusion of human whole blood over a collagen surface. Novel antibodies and peptides directed against the two collagen receptors were used to specifically unravel the function of each receptor molecule. GPVI was found to be crucial for platelet aggregate formation, $\mathrm{Ca}^{2+}$ signaling and PS exposure, but not for primary adhesion to collagen/vWF. Inhibition of $\alpha 2 \beta 1$ revealed that this integrin had a modulating role in $\mathrm{Ca}^{2+}$ signaling, PS exposure and aggregate size, since it enforced the responses evoked by GPVI. Interestingly, both GPIb-V-IX and $\alpha 2 \beta 1$ contributed to primary adhesion, and showed a partly overlapping function. Co-inhibition studies revealed synergism of distinct platelet receptors in thrombus formation. Co-inhibition of ADP with collagen receptors resulted in greatly decreased adhesion and aggregation. Co-inhibition of GPVI with either GPIb $\alpha$ or $\alpha 2 \beta 1$ was required to cause complete eradication of thrombus formation. It was concluded that platelet deposition on collagen depends on the concerted interplay of several receptors, GPIb-V-IX in synergy with integrin $\alpha 2 \beta 1$ mediating primary 
adhesion, reinforced by platelet activation through GPVI, which in turn regulates thrombus formation.

Coagulation activation with tissue factor may contribute to collagen-induced thrombus formation. Chapter $\mathbf{5}$ introduces an assay to trigger thrombin generation and coagulation in flow-adhesion experiments on collagen. Investigated was by which signaling pathway collagen-induced platelet activation interacts with tissue factortriggered coagulation both in vitro and in vivo. In murine blood flowing over collagen, platelet exposure of PS and procoagulant activity, but not adhesion, completely relied on each of the following signaling modules: GPVI, the FcR $\gamma$-chain, Src kinases, the adaptor protein LAT, and PLC $\gamma 2$. Upon flow in the presence of tissue factor, these signaling components were essential for platelet aggregation and greatly enhanced the formation of fibrin clots. The physiological importance of this GPVI pathway was shown in a $\mathrm{FeCl}_{3}$ induced in vivo murine thrombosis model. In both venules and arterioles, the presence and activity of GPVI, FCR $\gamma$-chain and Src kinases resulted in an enhanced formation of PS-exposing and fibrin-rich thrombi. These findings demonstrate that the GPVI-PLC $\gamma 2$ activation pathway can regulate collagen-dependent coagulation in venous and arterial thrombus formation.

In chapter 6, the mutually stimulatory processes of platelet activation and thrombin generation in arterial and venous thrombus formation in vivo were investigated in more detail. In the murine $\mathrm{FeCl}_{3}$ model, the thrombus-forming process appeared to be triggered by both collagen exposure and complex formation of tissue factor and factor VII(a). Interestingly, mild thrombin inhibition or platelet inhibition suppressed arterial thrombus formation, while strong thrombin inhibition or mild thrombin inhibition in combination with platelet inhibition was necessary to suppress venous thrombosis. Thrombus formation in both vessel types was characterized by the presence of PSexposing platelets, as detected with fluorescently labeled annexin A5. Shielding of exposed PS by injection of a surplus of unlabelled annexin A5 abolished the formation of both arterial and venous thrombi, while a mutant M1234-annexin A5 was ineffective. Surprisingly, decreased anticoagulant activity in mice carrying the factor $\mathrm{V}$ Leiden mutation had no more than little effect. Together, these findings demonstrated that the propagation of thrombin generation by PS-exposing platelets is a key regulatory process in both veins and arteries. Since platelet-dependent thrombin generation is most active in venous thrombus formation, this process may be a clinically relevant target for antithrombotic therapy.

As indicated, platelets play a dual role in thrombus formation by assembling into aggregates and by stimulating the coagulation. In chapter 7 we investigated the 178 
commitment of platelets to either of these functions both in vitro and in vivo. Highresolution two-photon fluorescence microscopy revealed that during thrombus formation under flow, fibrin(ogen)-binding platelets assembled into separated aggregates, after which distinct patches formed of non-aggregated platelets, exposing PS. The latter platelet population had inactivated $\alpha$ llb $\beta 3$ integrins and displayed increased binding of coagulation factors. Coated platelets, expressing serotonin binding sites, were not identified as a separate population. Thrombin generation (coagulation) favored the integrin inactivation and the transformation into PS-exposing platelets with reduced adhesion. Prolonged tyrosine phosphorylation in vitro resulted in secondary downregulation of active $\alpha$ llb $\beta 3$. Together, these results lead to a new, spatial model of thrombus formation, in which aggregated platelets ensure thrombus stability, while distinct patches of non-aggregated platelets effectuate procoagulant activity and generate thrombin and fibrin. Herein, the haemostatic activity of a developing thrombus seems to be determined by a balance in formation of proaggregatory and procoagulant platelets. This balance likely influences the efficacy of antiplatelet or anticoagulant medication.

The significance of the findings described in this thesis is discussed in chapter 8, particularly in the light of relevant, recent literature. In summary, the data recognize the GPVI pathway to PLC $\gamma 2$ activation as a key signaling mechanism for $\mathrm{Ca}^{2+}$-dependent PS exposure and procoagulant activity. Signaling proteins that cluster together in the LAT signallosome, including the $\mathrm{PI} 3 \mathrm{~K} \alpha$ and $\beta$ isoforms support this pathway. Yet, only the population of platelets with prolonged $\mathrm{Ca}^{2+}$ elevation and tyrosine phosphorylation shows this procoagulant activity. Altogether, the key role of GPVI in the thrombusforming process makes this platelet receptor as a promising new antithrombotic tool. However, the data also suggest that anti-GPVI treatment may be most effective in case of arterial thrombosis (low thrombin), rather than in case of venous thrombosis (high thrombin), since high thrombin formation can overrule the antithrombotic effect of antiGPVI treatment. This knowledge may help to develop improved treatment strategies of the still numerous patients who suffer from cardiovascular thrombotic diseases. 



\section{Samenvatting}


Trombose, dat wil zeggen verstopping van de bloedvaten is nog steeds een van de meest voorkomende aandoeningen in onze samenleving. De medische wereld maakt daarbij onderscheid tussen veneuze trombose (zoals bijvoorbeeld een trombosebeen) en arteriële trombose (zoals bij een hart- of herseninfarct). Veneuze trombose is het gevolg van ongewenste bloedstolling, waarbij een fibrineprop gevormd wordt in de aders of venen. Arteriële trombose daarentegen is veelal het gevolg van schade van de bloedvatwand en daaropvolgende activering van de bloedplaatjes, die daarbij samenklonteren tot een plaatjesprop of plaatjesaggregaat. Veelal wordt veneuze trombose tegengegaan door stollingsremmers ('bloedverdunners'), terwijl arteriële trombose eerder onderdrukt wordt door medicatie die de plaatjesactivering remt (bijvoorbeeld aspirine). De laatste jaren is echter ook nagegaan, in hoeverre combinatietherapie met stollings- en plaatjesremmers effectief is ter preventie van trombose. Onderzoek met geïsoleerd bloed, met name in Nederland uitgevoerd, heeft laten zien dat de processen van stolling en plaatjesactivering heel nauw met elkaar verweven zijn. Trombine, dat een belangrijk product is van de stolling, is tevens een van de meest krachtige activatoren van plaatjes. Anderzijds zorgen geactiveerde plaatjes voor een oppervlak, waarop stollingsreacties kunnen plaatsvinden. Dit lijkt echter tegengesteld aan de verschillende functies van stolling (trombine) en geactiveerde plaatjes bij veneuze en arteriële trombose. Het doel van het onderzoek beschreven in dit proefschrift is daarom na te gaan hoe de interacties tussen trombinevorming en plaatjesactivering afhankelijk zijn van de condities zoals die naar verwachting optreden tijdens veneuze en arteriële trombose.

Bloedplaatjes worden geactiveerd door een aantal ingewikkelde, trapsgewijs werkende signaleringsroutes, waarbij vele eiwitten betrokken zijn. Een algemeen overzicht van de routes, die relevant zijn voor dit proefschrift, is gegeven in hoofdstuk 1. Hier wordt het werkingsmechanisme uitgelegd van de receptor voor ADP, P2Y 12 , de trombinereceptoren PAR1 en PAR4, en de collageenreceptor glycoproteïne (GP)VI. Al deze receptoren activeren de zogenaamde fosfoinositide 3-kinase (PI3K) route, die zorgt voor de vorming van het signaleringslipide fosfoinositide-3,4,5-trifosfaat. Activering van PI3K door GPVI speelt een rol bij de rekrutering en activering van fosfolipase C- $\gamma 2$ (PLC $\gamma 2$ ) naar de plasmamembraan. Deze activering van PLC $\gamma 2$ leidt tot een verhoging van het intracellulaire calcium, dat gemobiliseerd wordt vanuit interne opslagplaatsen. Een daaropvolgende stap is de calcium-afhankelijke expositie van het stollingsactieve fosfatidylserine (PS) op het plaatjesoppervlak. Gememoreerd wordt dat PS-exposerende plaatjes actief zijn in de generatie van trombine en het stimuleren van de stollingsactivieit, doordat zij als bindingsplaats dienen van stollingsfactoren. Stimulering 
van de plaatjes via de $\mathrm{P}_{2} \mathrm{Y}_{12}$ en PAR receptoren leidt daarnaast tot activering van de Rap1b - PI3K - Akt route, die zorgt voor plaatjesaggregatie via activering van het integrine $\alpha \mathrm{llb} \beta 3$.

Het zeer zeldzame syndroom van Scott is een milde bloedingsziekte, die gekenmerkt wordt door een verminderde expositie van stollingsactief PS op geactiveerde plaatjes en andere bloedcellen. De literatuur bevatte aanwijzingen dat de calciuminstroom als gevolg van interne calciummobilisatie verstoord is in plaatjes van Scott-patiënten. Aangezien dit een verklarende factor zou kunnen zijn voor de verminderde procoagulante respons van deze plaatjes, is in hoofdstuk 2 onderzocht in hoeverre deze calciuminstroom daadwerkelijk veranderd is. In geïsoleerde plaatjes en geïmmortaliseerde B-cel lymfoblasten van twee verschillende Scott-patiënten zijn daarom metingen verricht aan zowel de calciuminstroom als de PS expositie. Er werden echter geen verschillen waargenomen tussen de cellen van Scott-patiënten en overeenkomstige cellen van controlepersonen. Wèl was in Scott plaatjes de mate van PS expositie na GPVI stimulatie sterk gereduceerd. Deze resultaten weerleggen daarmee de veronderstelling dat een deficiëntie in calcium-signaaltransductie ten grondslag ligt aan het Scott syndroom.

Inositol-bevattende fosfolipiden, die voornamelijk geproduceerd worden door $\mathrm{PI} 3 \mathrm{~K}$, spelen een rol bij de activering van plaatjes. Welke rol is nog niet helemaal duidelijk. Hoofdstuk 3 beschrijft onderzoek naar de functie van verschillende PI3K isovormen in plaatjes na activering met collageen of trombine. Voor dit onderzoek werd gebruik gemaakt van muizen, die deficiënt waren in ofwel de $p 85 \alpha$ regulerende subunit (klasse IA PI3K) ofwel de p110 katalytische subunit (klasse 1B PI3K), en verder van enkele nieuw ontwikkelde remmers van specifieke katalytische subunits. Wij konden aantonen dat zowel de $\mathrm{p} 85 \alpha$ als de katalytische $\mathrm{p} 110 \beta$ subunit bijdraagt aan de calciumsignalering en daaropvolgende PS expositie. In plaatjes gestimuleerd met collageen verloopt deze bijdrage via de klassieke calciumsignaleringsroute, dat wil zeggen door verhoging van PLC-afhankelijke calciummobilisatie en daarop volgende opslag-gemedieerde calciuminstroom. In tegenstelling tot de isovormen PI3K $\alpha$ en PI3K $\beta$ (beide klasse $1 \mathrm{~A}$ ), blijken de isovormen $\mathrm{PI} 3 \mathrm{~K} \delta$ en $\mathrm{PI} 3 \mathrm{~K} \gamma$ een minder belangrijke rol te hebben in dit proces.

Middels in vitro perfusieproeven, beschreven in hoofdstuk 4, is de rol van verschillende plaatjesreceptoren voor adhesieve eiwitten, namelijk het glycoproteïne lb (GPIb) en integrine $\alpha$ llb $\beta 3$ als receptoren voor von Willebrand factor (vWF), en GPVI en integrine $\alpha 2 \beta 1$ als receptoren voor collageen, onderzocht bij de trombusvorming. Het 
trombusvormende proces en de procoagulante activiteit zijn daarbij gemeten tijdens de stroming van humaan bloed over een collageenoppervlak onder een hoge afschuifsnelheid (shear rate). Gebruik werd gemaakt van nieuw ontwikkelde antilichamen en peptiden gericht tegen collageenreceptoren, teneinde de specifieke functie van elke receptor te ontrafelen. Gebleken is dat GPVI essentieel is voor de vorming van plaatjesaggregaten, de calciumsignalering en de PS expositie. Anderszins speelt GPVI geen rol in de primaire adhesie van plaatjes aan het collageen/vWF oppervlak. Integrine $\alpha 2 \beta 1$ heeft slechts een modulerende rol in de calciumsignalering, plaatjesaggregatie en PS expositie, doordat het de werking van GPVI versterkt. De glycoproteïnen GPIb en $\alpha 2 \beta 1$ overlappen elkaar gedeeltelijk in primaire adhesie. Coinhibitie van ADP- en collageenreceptoren geeft een sterk verminderde adhesie en aggregatie. Om complete remming van de trombusvorming te krijgen moet echter zowel GPVI als GPIb of $\alpha 2 \beta 1$ geblokkeerd worden. Op basis van deze resultaten konden wij concluderen, dat de plaatjesadhesie en -aggregatie op collageen bepaald worden door onderlinge samenwerking van de verschillende adhesieve receptoren: GPIb in synergie met $\alpha 2 \beta 1$ voor de primaire adhesie, welk in een proces dat versterkt wordt door GPVI leidt tot trombusvorming.

Op grond van de literatuur werd aangenomen dat activering van de stolling middels weefselfactor betrokken is bij de collageen-afhankelijke trombusvorming. Hoofdstuk 5 beschrijft een nieuwe methode om trombinegeneratie en stolling op te wekken, door bloed onder stromingscondities over collageen te leiden. Deze methode is gebruikt om de vraag te beantwoorden via welk signaleringspad de plaatjesactivering door collageen bijdraagt aan de stolling onder invloed van weefselfactor. In muizenbloed dat geperfundeerd werd over collageen bleek de expositie van PS, maar niet de plaatjesadhesie, volledig afhankelijk van de volgende signaleringmodules: GPVI, de FcR $\gamma$-keten, Src kinases, het adaptor eiwit LAT en PLC $\gamma 2$. In aanwezigheid van weefselfactor waren deze signaleringcomponenten essentieel voor de plaatjesaggregatie en droegen zij bij aan de vorming van fibrinestolsels. De fysiologische betekenis van dit GPVI signaleringspad werd onderzocht in een in vivo trombosemodel in muizen. Hierbij werd trombose opgewekt na vasculaire beschadiging met behulp van ijzertrichloride $\left(\mathrm{FeCl}_{3}\right)$. In de microscopische arteriën en venen van het darmvlies resulteerde de afwezigheid van actief GPVI, FcR $\gamma$-keten of Src kinases in een sterk verlaagde vorming van PSexposerende en fibrinerijke trombi. Deze bevindingen geven aan dat de activeringsroute van GPVI naar PLC $\gamma 2$ van belang is voor het trombusvormende proces, inclusief stolling en fibrinevorming onder arteriële en veneuze stromingscondities. 
De interactie tussen plaatjesactivering en trombinegeneratie in arteriële en veneuze trombusvorming in vivo is onderzocht in hoofdstuk 6. In hetzelfde $\mathrm{FeCl}_{3}$ trombosemodel bleek dat de trombusvorming op gang werd gebracht door vasculaire blootstelling van zowel collageen als weefselfactor. De trombusvorming in arteriën kon worden onderdrukt door plaatjesremming of door lage dosering van een trombineremmer. Echter in venen kon de trombusvorming alleen onderdrukt worden door een combinatie van beide remmers, of door een hoge dosis van de trombineremmer. De procoagulante respons van bloedplaatjes verdween na infusie van annexine A5, een eiwit dat bindt aan PS. Wanneer annexine A5 vooraf aan muizen toegediend werd, resulteerde dit in een complete remming van de trombusvorming in beide typen bloedvaten. Dat er inderdaad procoagulante bloedplaatjes aanwezig zijn in de arteriële en veneuze trombi werd bevestigd door deze in vivo aan te kleuren met fluorescerend annexine A5. Verrassend genoeg had verlaagde antistollingsactiviteit in muizen met een factor $V$ Leiden-mutatie slechts een klein effect op het tromboseproces. Samen laten deze resultaten zien dat de versterking van trombinegeneratie door PSexposerende plaatjes van belang is voor het trombotische proces in venen en arteriën. Aangezien PS-afhankelijke trombinegeneratie het meest actief lijkt bij de veneuze trombusvorming, kan deze plaatjesreactie een doelwit zijn voor nieuwe antitrombotische therapie.

Zoals eerder aangegeven hebben plaatjes een tweeledige rol in het proces van trombusvorming, namelijk door vorming van aggregaten en door stimulering van de bloedstolling. In hoofdstuk 7 onderzochten wij welke van deze twee functies plaatjes vertonen na activering onder in vitro of in vivo condities. Hoge resolutie tweefoton fluorescentie-microscopie liet zien dat tijdens de trombusvorming een groot aantal fibrinogeen-bindende plaatjes clusterde tot aggregaten, terwijl een andere groep van niet-aggregerende plaatjes PS exposeerde. Deze laatste plaatjespopulatie bleek in versterkte mate stollingsfactoren te binden, terwijl hun $\alpha$ llb $\beta 3$ integrines in een nietactieve conformatie waren. Zogenaamde 'coated' plaatjes, die gekarakteriseerd zijn door een expressie van serotonine bindingsplaatsen, vormden geen aparte populatie. Interessant is dat de vorming van trombine (stolling) de inactivering van integrines bevorderde en ook zorgde voor een verhoogde transformatie van plaatjes tot losse, PSexposerende cellen. De secundaire inactivering van $\alpha$ llb $\beta 3$ integrines kon herleid worden tot een verlengde fosforylering van tyrosines middels protein tyrosinekinasen. Samengevat resulteren deze resultaten in een nieuw, ruimtelijk model van trombusvorming, waarbij clusters van geaggregeerde plaatjes zorgen voor trombusstabiliteit, terwijl andere, niet-aggregerende plaatjes zorgen voor de 
procoagulante activiteit en de vorming van trombine en fibrine. Verondersteld wordt dat de hemostatische activiteit van een zich ontwikkelende trombus een resultante is van de balans in vorming van proaggregerende en procoagulante plaatjes. Deze balans is waarschijnlijk van belang voor de werkzaamheid van antiplaatjes- en antistollingsmedicatie.

Hoofdstuk 8 beschrijft het belang van de bevindingen van dit proefschrift in het licht van relevante, recente literatuur. Aangegeven is dat de GPVI route naar PLC $\gamma 2$ activering van groot belang is voor calcium-afhankelijke PS expositie en de procoagulante activiteit van plaatjes. Diverse signaleringseiwitten die samenklonteren in het LAT signalosoom zijn betrokken bij het ontstaan van deze procoagulante activiteit, inclusief de PI3K $\alpha$ en $\beta$ isovormen. De cruciale rol van het GPVI signaleringpad in het trombusvormende proces maakt de GPVI receptor tot een veelbelovend doeleiwit voor nieuwe antitrombotische middelen. Het is daarbij te verwachten dat anti-GPVI behandeling het meest effectief zal zijn bij de preventie van arteriële trombose (laag trombine) en minder effectief bij de veneuze trombose (hoog trombine). Immers een hoge trombinevorming zal het antitrombotische effect van een anti-GPVI behandeling ongedaan kunnen maken. De in dit proefschrift beschreven kennis zal hopelijk bijdragen tot de ontwikkeling van nieuwe behandelingsmethoden voor de nog zeer vele trombosepatiënten. 


\section{Dankpuzzel}

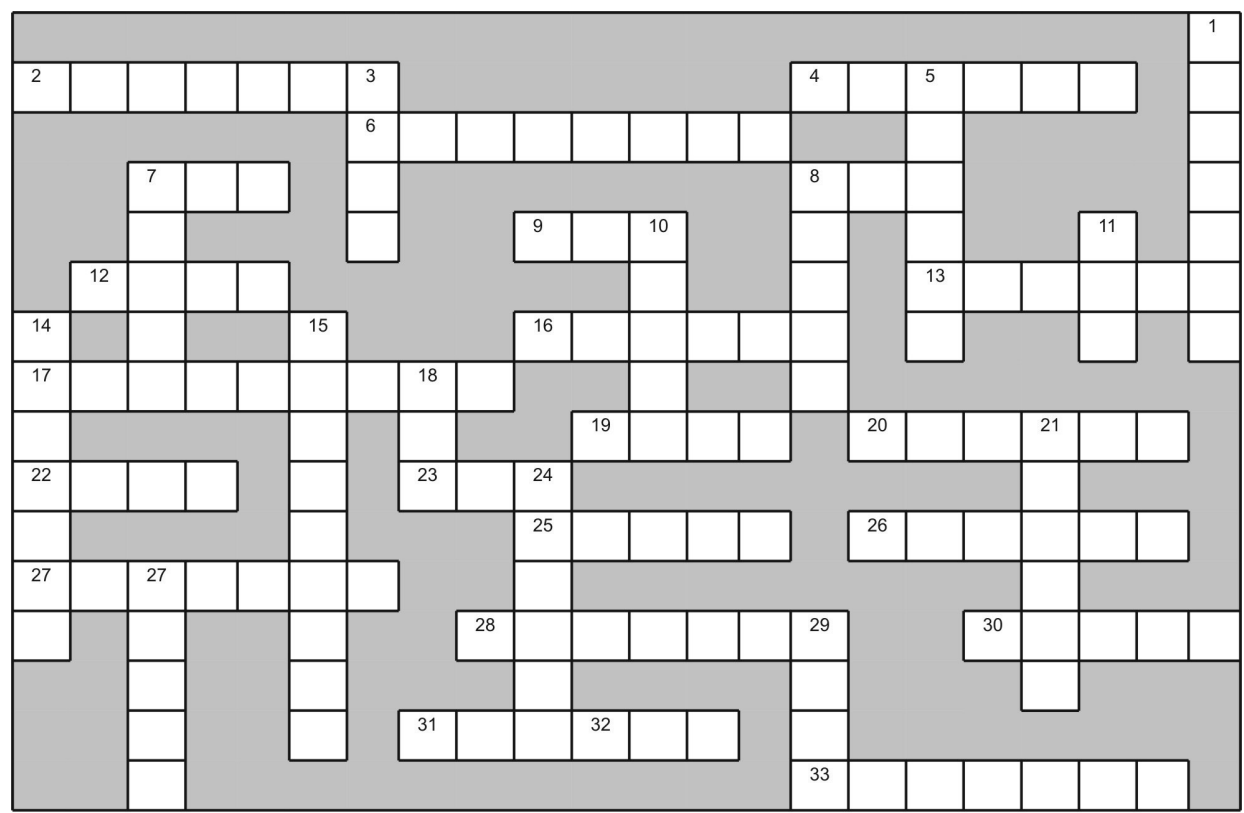

\begin{tabular}{|l|l|l|l|l|l|l|}
\hline 15 & 29 & 32 & 25 & 3 & 33 & 12 \\
\hline
\end{tabular}

\section{Horizontaal}

2 enthusiastic Birmi-girl 4 de dokter in huis 6 degenen die ik vergeten ben 7 de grote baas 8 deze extroverte Belgische windt er geen doekjes om 9 bezorgde topklusser en onvoorwaardelijke steun 12 degene die de deur naar Biochemie opende....zucht! 13 m'n enige echte zus en reismaatje 16 gezellige, ongedwongen crea-bea 17 master op MTB, bijna master in de kinderfysio: de top is de limit 19 voor iedere foton een dochter 20 vasculaire, oogopende meedenktank 22 mijn liefste huisgenootje ooit $\mathbf{2 3}$ de tafeltje-dekster aan het thuisfront en toekomstig kunstenares? 25 m'n onechte tweelingzusje die hard-loopt door het embryonale wereldje van de meerlingen 26 recht voor z'n raap en eerste hulp op reis $\mathbf{2 7}$ m'n bed and breakfast adresje $\mathbf{2 8}$ alles pluis met de muis? materiaal zorgvuldig in de kluis! 30 expert in superb spicy curries $\mathbf{3 1}$ avontuurlijke Belgische met doorzettingsvermogen 33 visolie distributeur en Audiminded: Deutsche gründlichkeit?

\section{Verticaal}

1 oost, west, Posterholt best 3 de eerste zwangere man $\mathbf{5}$ klein van stuk, speelt graag toneel, maar neemt geen blad voor de mond 7 de gedreven plaatjesexpert, alias de harembewaarder 8 m'n kleine zusje en de benjamin van de groep 10 hippe, altijd jatsende flatmate 11 proud mother and good scientist 14 m'n grote voorbeeld en muizenvanger 15 collegiale groep bloedzuigers die bloedstollend werk verrichten 18 deze reislustige echtgenote kan van chocolade echt genieten 21 kordate, maar krachtige Obbichtse met strakke plannen 24 labmanager en psychologe in èèn $\mathbf{2 7}$ wekt spanning op in vaten en tevens in zijn fietsbanden 29 hij heeft mij de promotiebal op hoog niveau toegespeeld 


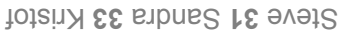

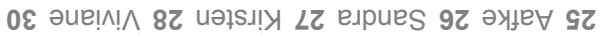

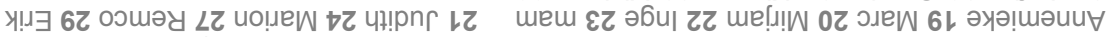

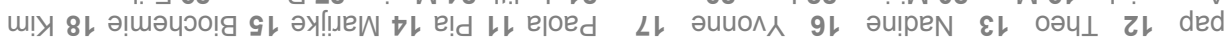

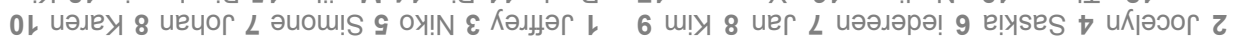
ןеeว!นə^

ןеeтuoz!ıoH

\section{6u!ssoldo}




\section{Curriculum vitae}

Imke Munnix werd geboren op 16 maart 1979 te Roermond. Na voltooiing van het Voorbereidend Wetenschappelijk Onderwijs (WO) aan het Bisschoppelijk College Schöndeln te Roermond, startte ze in 1997 met de opleiding Gezondheidswetenschappen aan de Universiteit Maastricht. Na het behalen van haar propedeuse in 1998 vervolgde zij deze studie in de richting Biologische Gezondheidskunde. Tijdens haar studie slaagde zij voor het examen Stralingshygiëne, deskundigheidsniveau $5^{\mathrm{b}}$. Haar afstudeerstage liep zij in 2001 bij de capaciteitsgroepen Biochemie en Moleculaire Genetica onder begeleiding van Dr. J.W.M. Heemskerk en Dr. G.J.J.M. van Eys. Voor een extra buitenlandstage vertrok ze in april 2001 voor 5 maanden naar Cambridge, Engeland. Hier deed zij onderzoek bij the Department of Physiology, University of Cambridge, onder begeleiding van Dr. S.O. Sage. Op 30 september 2001 mocht zij haar universitaire diploma in ontvangst nemen. Per oktober 2001 begon zij als onderzoeksassistent binnen het Cardiovascular Research Institute Maastricht (CARIM) van de Universiteit Maastricht bij de capaciteitsgroep Biochemie van Prof. Dr. J. Rosing. Hier werd zij per november 2002 Assistent in Opleiding (AIO) op een project gesubsidieerd door de Nederlandse Hartstichting. Het onderzoek dat zij daar deed en wat beschreven staat in dit proefschrift vond plaats onder directe begeleiding van $\mathrm{Dr}$. J.W.M. Heemskerk. Na het volgen van verscheidene cursussen werd haar in 2005 het CARIM PhD-Training Certificate uitgereikt. Tevens verwierf ze de status van artikel 9deskundigheid volgens de Wet op Dierproeven. Zij bezocht verschillende congressen in onder andere Birmingham, Eberbach, Erfurt, Nottingham, Oxford, Reading en Sydney om haar onderzoeksresultaten te presenteren en won hiervoor tweemaal een "young investigator award". Zij bezocht verscheidene malen het Institute of Molecular Cell Biology, University of Jena (Duitsland) van Dr. R. Heller om daar proeven te doen. Tevens werkte zij in 2006 gedurende 3 maanden bij het Centre for Cardiovascular Sciences Institute of Biomedical Research, University of Birmingham (Engeland), onder leiding van Prof. Dr. S. Watson. Sinds 1 maart 2007 is zij werkzaam als postdoctoraal onderzoeker bij de capaciteitsgroep Biochemie van de Universiteit Maastricht. 


\section{Curriculum vitae}

Imke Munnix was born on March $16^{\text {th }} 1979$ in Roermond, the Netherlands. After completing secondary school (VWO) at the Bischoppelijk College Schöndeln in Roermond in 1997, she started to study Biological Health Sciences at Maastricht University. During her study she passed the exam Radiation hygiene, expertise level $5^{b}$. In 2001, she followed her graduation internship at the Departments of Biochemistry and Molecular Genetics, under supervision of Dr. J.W.M. Heemskerk and Dr. G.J.J.M. van Eys. In the same year, she spent five months in Cambridge, United Kingdom, for a research internship at the Department of Physiology, University of Cambridge, under the guidance of Dr. S.O. Sage. On September $30^{\text {st }} 2001$ she received her Master's degree. On October $1^{\text {st }}$ she started as a research assistant at the Cardiovascular Research Institute Maastricht (CARIM), Maastricht University, at the Department of Biochemistry directed by Prof. Dr. J. Rosing. From November on she worked here as a PhD student on a project financed by the Netherlands Heart Foundation. This research, which is described in the present thesis, was supervised by Dr. J.W.M. Heemskerk. After taking several courses, she received the CARIM PhD training certificate and became an Article 9 expert according to the Law on Animal experiments. She visited congresses in Birmingham, Eberbach, Erfurt, Nottingham, Oxford, Reading and Sydney to present research data, which were honoured twice with a Tyoung investigator award!. She visited the Institute of Molecular Cell Biology of Dr. R. Heller at the University of Jena (Germany) for several times to perform experiments. In 2006, she worked for 3 months at the Centre for Cardiovascular Sciences Institute of Biomedical Research, University of Birmingham (United Kingdom) under the supervision of Prof. Dr. S. Watson. Since March $1^{\text {st }} 2007$ she is working as a postdoctoral researcher at the Department of Biochemistry at Maastricht University. 


\section{List of publications}

\section{Full Papers}

- Munnix ICA, Harmsma M, Giddings JC, Collins PW, Feijge MAH, Comfurius P, Heemskerk JWM, Bevers EM. Store-mediated calcium entry in the regulation of phosphatidylserine exposure in blood cells from Scott patients. Thromb Haemost. 2003; 89: 687-695.

- $\quad$ Siljander PRM, Munnix ICA, Smethurst PA, Deckmyn H, Lindhout T, Ouwehand WH, Farndale RW and Heemskerk JWM. Platelet receptor interplay regulates collagen-induced thrombus formation in flowing human blood. Blood. 2004; 103: 1333-1341.

- Heemskerk JWM, Kuijpers MJE*, Munnix ICA ${ }^{\star}$ and Siljander PRM. Platelet collagen receptors and coagulation. A characteristic platelet response as possible target of antithrombotic treatment. Trends Cardiovasc Med. 2005; 15:86-92.

- Munnix ICA, Strehl A, Kuijpers MJE, Auger JM, van der Meijden PEJ, van Zandvoort MAMJ, oude Egbrink MGA, Nieswandt B and Heemskerk JWM. The glycoprotein $\mathrm{VI}$ - phospholipase $\mathrm{C} \gamma 2$ signaling pathway controls collagen- and tissue factor-induced thrombus formation in vitro and in vivo. Arterioscler Thromb Vasc Biol. 2005; 25: 2673-2678.

- Kuijpers MJE, Munnix ICA en Heemskerk JWM. Trombusvorming in vitro en in vivo: identificatie van glycoproteïne $\mathrm{VI}$ als essentiële collageenreceptor op bloedplaatjes. Tromnibus. 2006; 34: 5-10.

- Cosemans JMEM, Munnix ICA, Wetzker R, Heller R, Jackson SP and Heemskerk JWM. Continuous signaling via PI3K isoforms $\beta$ and $\gamma$ is required for platelet ADP receptor function in dynamic thrombus stabilization. Blood. 2006; 108: 3045-3052.

- Strehl A, Munnix ICA, Kuijpers MJE, Feijge MAH, Cosemans JMEM, van der Meijden PEJ, Nieswandt B and Heemskerk JWM. Dual role of platelet protein kinase $\mathrm{C}$ in thrombus formation: stimulation of proaggregatory and suppression of procoagulant activity. J Biol Chem. 2007; 282: 7046-7055.

\section{Full papers (submitted)}

- Munnix ICA, Cosemans JMEM, Feijge MAH, van der Meijden PEJ, van Montfoort APA, Farndale RW, Koyasu S, Heller R, Sage SO, Jackson SP and Heemskerk JWM. Specific roles of PI3K isoforms $\alpha$ and $\beta$ in glycoprotein VI-induced platelet signaling to procoagulant activity. Submitted, 2007.

- Kuijpers MJE*, Munnix ICA*, Cosemans, JMEM, van Vlijmen BJM, Reutelingsperger CPM, oude Egbrink MGA and Heemskerk JWM. Key role of platelet procoagulant activity in tissue-factor- and collagen-induced thrombus formation in arteries and veins in vivo. Submitted, 2007.

- Munnix ICA, Kuijpers MJE, Auger J, Thomassen CMLGD, Panizzi P, van Zandvoort MAMJ, Rosing J, Bock P, Watson SP, and Heemskerk JWM. Signaling-induced 
transient integrin activation controls segregation of procoagulant and aggregatory microdomains in thrombus formation. Submitted, 2007.

- Donners M, Beckers L, Lievens D, Janssen B, Newby A, Munnix ICA, Heemskerk JWM, Noelle R, Daemen M, Lutgens E. The CD40-TRAF6 axis is the key regulator of neo-intima formation and vascular remodelling. Submitted, 2007.

- Van der Meijden PEJ, Schoenwaelder SM, Feijge MAH, Cosemans JMEM, Munnix ICA, Wetzker R, Heller R, Jackson SP and Heemskerk JWM. Dual regulation by P2Y12 receptors of platelet activation under coagulant conditions. Involvement of phosphoinositide 3-kinase $\beta$ but not $\gamma$ isoform. Submitted, 2007.

- Kuijpers MJE, Pozgajova M, Cosemans JMEM, Munnix ICA, Eckes B, Nieswandt $B$, and Heemskerk JWM. Unidentified role of murine integrin $\alpha 2 \beta 1$ in thrombus stabilization and embolization. Thromb Haemost. Major revision 2007.

- $\quad$ van der Meijden PEJ, Munnix ICA, Kuijpers MJE, Auger JM, Watson SP and Heemskerk JWM. Contribution of glycoprotein VI signalling to the intrinsic pathway of coagulation. In preparation, 2007.

- Lievens D, Munnix ICA, Beckers L, Donners MM, Noelle RJ, de Winther MP, Heemskerk JWM, Daemen MJ, Lutgens E. Cell type specific CD40(L) signaling in atherosclerosis: role of platelet and leukocyte CD40(L) on plaque development. In prepraration, 2007.

\section{Awards}

- Travel awards from the Dutch Cancer Foundation (KWF) and the University Foundation Limburg (SWOL) to visit the Department of Physiology from Cambridge University (2001).

- Poster award, Euregional Life Science Conference, Maastricht 2004.

- Young investigator award of the International Society on Thrombosis and Haemostasis, XXth Congress ISTH, Sydney, Australia (August 2005).

- Young investigator award of the Netherlands Foundation for Thrombosis and Haemostasis to visit XXth Congress ISTH, Sydney, Australia (April 2005).

- Travel award from the Netherlands Heart Foundation to visit the Centre for Cardiovascular Sciences Institute of Biomedical Research from Birmingham University (2006). 